\title{
Bildgebende zerstörungsfreie Prüfmethoden in der Kulturerbeforschung
}

\author{
Inaugural-Dissertation \\ an der Fakultät Geistes- und Kulturwissenschaften \\ der Otto-Friedrich-Universität Bamberg
}

vorgelegt von

Max Rahrig M.A.

aus

Höxter

Bamberg, den

16.09.2019 
Dieses Werk ist als freie Onlineversion über das Forschungsinformationssystem (FIS; https://fis.uni-bamberg.de) der Universität Bamberg erreichbar

URN: urn:nbn:de:bvb:473-irb-515663

DOI: https://doi.org/10.20378/irb-51566

Tag der mündlichen Prüfung: 05.02.2020

Dekan: $\quad$ Professor Dr. Markus Behmer

Betreuer: $\quad$ Professor Dr. Paul Bellendorf

Weitere Gutachter: $\quad$ Professor Dr.-Ing. Marc Stamminger

Professor Dr.-Ing. Dr. h.c. Thomas Luhmann 
Elke und Fritz 



\section{Danksagung}

Diese Arbeit entstand im Rahmen meiner Arbeit als wissenschaftlicher Mitarbeiter am Kompetenzzentrum für Denkmalwissenschaften und Denkmaltechnologien (KDWT) der OttoFriedrich-Universität Bamberg. Daher gilt mein größter Dank Prof. Dr. Rainer Drewello, dem langjährigen Sprecher des KDWT, der mich bereits in den frühen Anfängen meines Studiums für die Wissenschaft und Forschung begeistern konnte. Mit seiner unermüdlichen Art, neue Ideen zu entwickeln und Themengebiete zu erschließen, war für mich sehr schnell klar, dass im Anschluss an mein Magisterstudium der Archäologie eine Vertiefung in den Restaurierungswissenschaften erfolgen musste. Ich bin zutiefst dankbar, dass er mir die Freiheit und ungebremste Unterstützung in der Entwicklung eigener Forschungsideen gewährte, dabei stets mit Ratschlägen aber auch Mahnungen beiseite stand und im richtigen Moment Möglichkeiten für die Realisierung der Projektideen wusste. Die schier unfassbaren Möglichkeiten, die mir das KDWT in den letzten Jahren bieten konnte, haben einen großen Beitrag bei der Entwicklung eines eigenen Forschergeistes und für das Gelingen dieser Arbeit geleistet.

Nicht weniger Dank gilt Prof. Dr. Paul Bellendorf, für den ich bereits als studentische Hilfskraft arbeiten durfte. Später verfolgte er als Mentor meinen wissenschaftlichen Werdegang. Es freute mich somit überaus, als er den Ruf für die Professur für Restaurierungswissenschaften in Bamberg erhielt, wodurch wir wieder gemeinsam an Projekten arbeiten konnten. Ich bin ihm für die unentwegte Unterstützung in den letzten Jahren mehr als dankbar und freue mich, dass er auch die Betreuung und Erstbegutachtung dieser Arbeit übernommen hat. Weiterer Dank gilt Prof. Dr. Marc Stamminger, meinem zweiten Gutachter. Ich freue mich mit ihm einen Betreuer aus dem Bereich des Visual Computing gewonnen zu haben, wodurch die Betreuung der technischen Aspekte dieser Arbeit erfolgen konnte. Ferner möchte ich mich bei Prof. Dr. Dr. Thomas Luhmann für das dritte Gutachten und die anregenden Tips und Empfehlungen bedanken.

Meinen Kolleg*innen am KDWT, hier besonders Ruth Tenschert, David Höpfner, John Hindmarch, Lisa Selitz, Anna Luib und meinen beiden Hiwis Leander Pallas und Christoph Altmann, gilt ebenfalls großer Dank. Sie haben mir stets mit Rat und Tat beiseite gestanden und so einen wichtigen Beitrag für das Gelingen dieser Arbeit geleistet, besonders bei der gemeinsamen Bearbeitung der Projekte und dem stundenlangen Korrekturlesen.

Natürlich möchte ich die Gelegenheit auch nutzen, um meiner Familie zu danken und hier ganz besonders Eva, für ihre unermüdliche Unterstützung und ihren Rückhalt in den letzten Jahren. Danke! 


\section{Zusammenfassung}

Der Einsatz von berührungslosen, dreidimensionalen Vermessungsgeräten hat sich in den letzten 10 bis 15 Jahren mehr und mehr in der Kulturerbeforschung etabliert. Unter dem schützenden Feigenblatt des Verweises auf die Verwendung neuer Techniken, deren eingehende Erprobung noch aussteht, wurde dabei jedoch häufig auf die Einhaltung gängiger ethischer Grundlagen und damit dem Ziel eines tatsächlichen Mehrwerts für das Kulturerbe verzichtet. ${ }^{1}$ Dies mag für die Anfänge der Verwendung einer zerstörungsfreien Technologie hinnehmbar sein, doch werden damit zusehends das Potential und der Mehrwert des gezielten Einsatzes dieser Technologien verunklärt. Es droht die Gefahr, ein nützliches Werkzeug lediglich als Spielerei zum Selbstzweck oder für reißerische Visualisierungen abzustempeln.

In der hier vorliegenden Arbeit soll daher der Mehrwert und praktische Nutzen neuer Technologien für den analytischen Einsatz in der Kulturerbeforschung, als Werkzeug für die Untersuchung und Dokumentation von materiellem Kulturerbe herausgearbeitet und klar dargestellt werden. Der Schwerpunkt liegt dabei in dem Einsatz von bildgebenden, berührungslosen und zerstörungsfreien optischen Messtechniken. Konkret werden hierbei verschiedene Methoden zur dreidimensionalen Erfassung von komplexen Oberflächen ganzer Bauwerke bis hin zu kleinsten Oberflächenmerkmalen im Submillimeterbereich sowie die multispektrale Bildgebung behandelt. Neben der Darstellung von Möglichkeiten und Limitationen bei der Erhebung der Daten, beispielsweise aufgrund der im Kulturgut verwendeten Materialien, werden verschiedene Verfahren zur Auswertung der Daten dargestellt. Einen besonderen Schwerpunkt wird dabei die Anwendung von 3D-Inspektionssoftware zum Vergleich von 3D-Modellen darstellen. Hierbei handelt es sich um ein Werkzeug welches bisher kaum Anwendung in der Kulturerbeforschung fand, jedoch besonders für das Erfassen von Veränderungen eines Objektes zwischen zeitlich versetzten Digitalisierungen geeignet ist. Wie in der Arbeit dargestellt wird, ergeben sich hierdurch Möglichkeiten zur Detektion von Schadensprozessen, gleichermaßen wie die Evaluation von Konservierungsmitteln und der kunstwissenschaftliche Vergleich von in Serie produzierten Kunstobjekten. Ausgangspunkt für die in der Arbeit vorgestellten Arbeitsweisen und Anwendungen der Methoden stellt dabei stets eine konkrete Fragestellung ausgehend vom Objekt dar, nach welcher die jeweilige Technik ausgewählt und gezielt angewendet wurde. Besonders ist dabei der kombinierte Einsatz verschiedener Techniken wie etwa der 3D-Oberflächendokumentation und der multispektralen Bildgebung herauszustellen, wodurch sich Einschränkungen einzelner Methoden kompensieren und so ein Mehrwert in der Untersuchung der Kulturgüter herausarbeiten lässt. So konnte der Nutzen dieser Technologien als Werkzeuge für die Kulturerbeforschung und besonders der Präventiven Konservierung herausgearbeitet werden. Die behandelten Schwerpunkte

\footnotetext{
${ }^{1}$ Vgl. Hirst et al. 2018.
} 
umfassen dabei die berührungslose Dokumentation von Objekten für eine denkmalgerechte Zu- und Bestandserfassung, innerhalb der Kulturerbeforschung eine fächerübergreifende Analyse und Observation sowie das Monitoring von Kulturerbe und die langfristige Speicherung und Archivierung der erhobenen Daten.

In Ermangelung ethischer Grundsätze für das große Feld der Kulturerbeforschung und an passenden Richtlinien für eine denkmalgerechte, digitale Dokumentation, werden in dieser Arbeit zudem ethische Leitsätze für die Kulturerbeforschung, unter Anlehnung an die etablierten Vorgaben und Empfehlungen innerhalb der Konservierung und Restaurierung, formuliert. Diese Leitsätze sind dabei als Vorschlag für die Wahrung eines denkmalgerechten Umgangs mit dem Objekt durch alle beteiligten Disziplinen und Akteur*innen zu sehen. Durch sie soll die Notwendigkeit und der Bedarf der Definition solcher Richtlinien herausgestellt werden. Sie dienen dabei als Appell an internationale Institutionen wie etwa ICOMOS, ICOM und ICCROM dem Desiderat fehlender, vereinfachter ethischer Leitsätze für Fachdisziplinen, welche nur zeitweise in der Kulturerbforschung involviert sind, entgegenzuwirken.

\section{Anmerkung}

Bei der vorliegenden Arbeit handelt es sich um eine publikationsbasierte Dissertationsschrift, der insgesamt sechs Artikel/Publikationen zugrunde liegen. Diese sind hier als Post-Prints in einer im Layout der Arbeit angepassten Form wiedergegeben. Für eine korrekte Zitation wird vor dem jeweiligen Artikel auf die Erstveröffentlichung als Originalquelle verwiesen. Aufgrund unterschiedlicher Vorgaben der Verlage und Herausgeber wurden teilweise unterschiedliche Zitationsstile in den Veröffentlichungen verwendet, welche hier übernommen wurden.

Die abgebildeten 3D-Oberflächenvergleiche sind in ihrer Farbgebung für eine elektronische Betrachtung ausgelegt. In der Druckversion der Dissertationsschrift kann es daher zu Unschärfen und einer beeinträchtigten Farbwiedergabe kommen, es wird daher empfohlen zur Betrachtung der Oberflächenvergleiche auf die vorliegende PDF-Version zurückzugreifen. 


\section{Inhaltsverzeichnis}

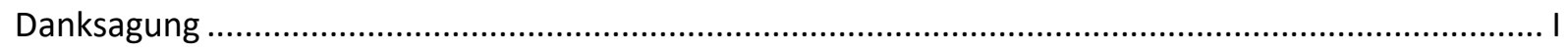

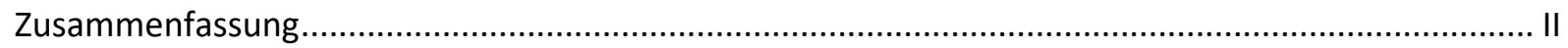

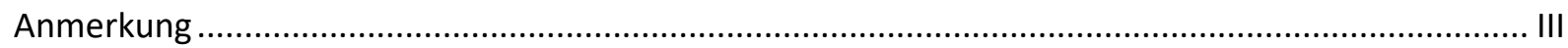

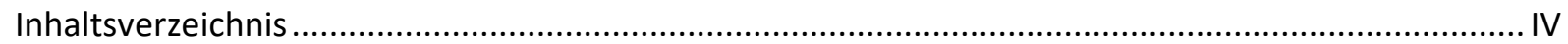

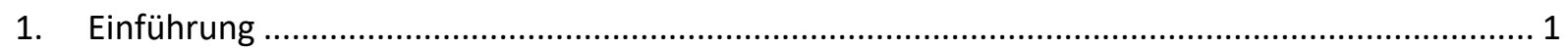

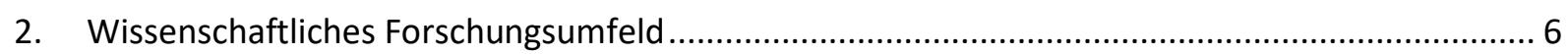

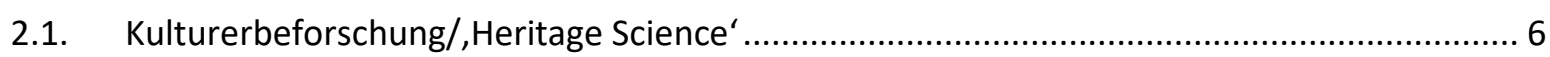

2.2. Restaurierungswissenschaft als Teil der Kulturerbeforschung ...................................... 7

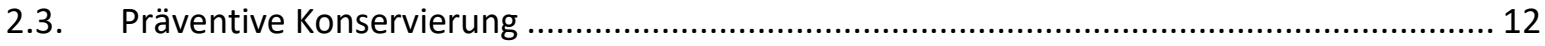

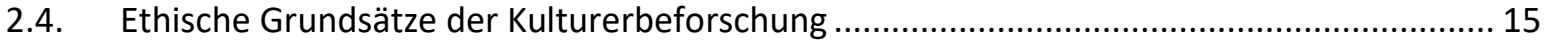

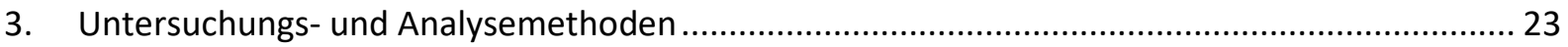

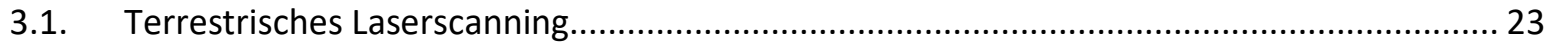

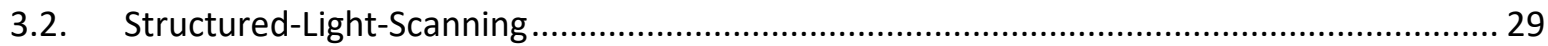

3.3. Image-Based Modelling / Structure from Motion...................................................... 35

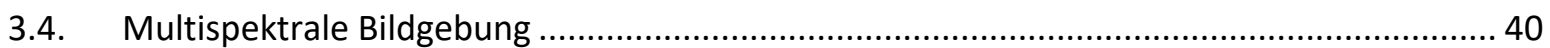

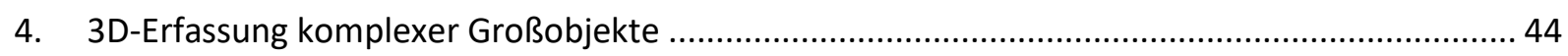

4.1. Der Zahntempel - Kulturerbeforschung und Wissenstransfer .....................................45

Publikation 1: Sri Dalada Maligawa - 3D-Scanning and Documentation of the Temple of the Sacred Tooth Relic at Kandy, Sri Lanka (Rahrig/Luib 2017).................................................. 46

4.2. Der Bamberger Kaisersaal - Neue Möglichkeiten für eine kunsthistorische Analyse historischer Prunkräume....

Publikation 2: Praxistaugliche Digitalisierung barocker Prunkräume - hochauflösende 3D-

Dokumentation des Kaisersaals der Neuen Residenz in Bamberg (Rahrig 2019b)....

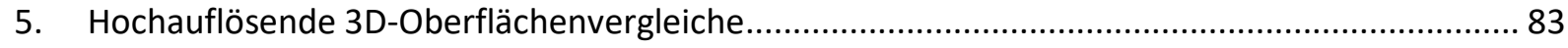

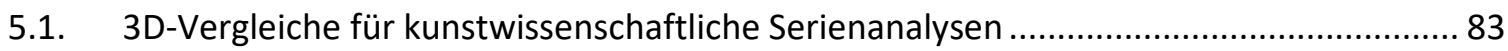

Publikation 3: Rethinking Uniformity: Analysis of Rosso's Serial Forms of the Bambino ebreo through Digital Surface Comparison (Rahrig/Street 2019)

5.2. 3D-Vergleiche für die Oberflächeninspektion und Qualitätskontrolle im laufenden Restaurierungsprozess . 108

Publikation 4: 3D Inspection of the Restoration and Conservation of Stained Glass Windows using High Resolution Structured Light Scanning (Rahrig/Torge 2019) 
6. Opto-Technical Monitoring-3D-Techniken und multispektrale Bildgebung.

Publikation 5: Opto-Technical Monitoring - A Standardized Methodology to Assess the Treatment of Historical Stone Surfaces (Rahrig/Drewello/Lazzeri 2018) 128

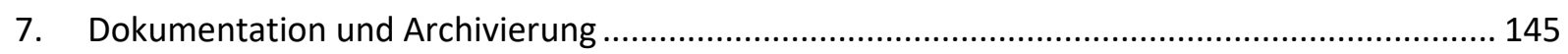

Publikation 6: Wohin mit all den Scans? Über die dauerhafte Archivierung von 3D-Daten bedeutender Kulturgüter am Beispiel des Bamberger Kaisergrabs (Rahrig 2017) ..... 146

Nachtrag zu Publikation 6. 160

8. Übergreifende Diskussion. 161

Abbildungsverzeichnis 169

Literaturverzeichnis 171 


\section{Einführung}

"If we cannot clearly and simply tell/convince society why we do what we do, what right do we have to intervene with society's most valued and treasured objects?"2

Die vorliegende Arbeit befasst sich mit der Verwendung von dreidimensionalen Dokumentationsmethoden und zerstörungsfreien optischen Messtechniken als bildgebende zerstörungsfreie Prüfmethoden im Anwendungsgebiet der Kulturerbeforschung. Das analytische Monitoring von Oberflächen als Werkzeug der Restaurierungswissenschaften wird dabei einen Schwerpunkt der Arbeit bilden.

3D-Scanning und vergleichbare hochauflösende dreidimensionale Dokumentationstechniken haben sich in den letzten 15 Jahren in den Bereichen der Archäologie, Bauforschung und Restaurierung etabliert. Der Einsatz dieser Techniken beschränkt sich dabei vielfach auf die Dokumentation der Oberflächen eines historischen Objekts, sowohl für kleine Fundstücke als auch für ganze Gebäudeensembles. Die so erhobenen Daten werden für die Generierung von CAD-Plänen, von verzeichnungsfreien, detaillierten Ansichten, sowie für 3D-Animationen oder die Erstellung von Kopien, wie etwa aus dem 3D-Drucker, verwendet. Dabei ist zu beobachten, dass die zum Teil aufwendig und kostenintensiv erhobenen Daten für die wissenschaftliche Bearbeitung sehr häufig wieder zurück auf eine zweidimensionale Ebene reduziert werden. Die dreidimensionale Komponente hingegen wird häufig zur Vermittlung als 3D-Animationen in der musealen Präsentation sowie zur Veranschaulichung des Forschungsgegenstandes auf Fachtagungen und Ähnlichem verwendet.

Im Zusammenspiel von wissenschaftlicher Dokumentation und Öffentlichkeitsarbeit wird der Mehrwert der dreidimensionalen Dokumentation historischer Objekte demnach gut genutzt, doch die Möglichkeiten für den analytischen Einsatz in der Kulturerbeforschung werden vielfach deutlich unterschätzt. Aus einer Betrachtung des Forschungsumfeldes erschließt sich der Grund für dieses Desiderat.

Auf der einen Seite stehen die klassischen, geisteswissenschaftlich geprägten Disziplinen, die sich seit jeher mit historischen Objekten befassen. Hierunter fallen untere anderem die Archäologie, Kunstgeschichte, Bauforschung, oder Restaurierung, allesamt Wissenschaften, die aufgrund unterschiedlicher Schwerpunktsetzungen in den Fragestellungen eigene Arbeitsweisen und Methoden entwickelt haben. Die Adaption neuer Techniken gehörte dabei schon immer zu den Aufgaben dieser Forschungsfelder. Ausgangspunkt hierfür war jedoch stets die jeweilige Fragestellung an das

\footnotetext{
${ }^{2}$ Caple 2009, S. 25.
} 
historische Objekt und in der Regel nicht die Anwendung und Erprobung einer völlig neuen Technologie. Der Forschungsschwerpunkt dieser Disziplinen liegt schließlich meist in der Arbeit mit dem Objekt, sei es bei der Erforschung von Herstellungstechniken, Bauabfolgen, der Interpretation von Fundumständen, der Interaktion zwischen Künstler, Kunstwerk und Betrachter oder der Erfassung der Veränderungs- und Schadensgeschichten.

Auf der anderen Seite stehen die mathematisch-technisch orientierten Disziplinen der Informatik, Geoinformatik, Photogrammmetrie, Fernerkundung, automatisierten Fertigungstechniken und des Reverse Engineering. Hierbei handelt es sich um die wissenschaftlichen Bereiche, in denen die dreidimensionale Vermessung von Objekten entwickelt wurde und, ausgerichtet nach dem Bedarf der Industrie und Wissenschaft, weiterentwickelt wird. Auch wenn diese Disziplinen in der Regel wenig Erfahrung mit dem Umgang und den Anforderungen an historische Objekte haben, ist der Einsatz der Technik im Kontext historischer Objekte gerne gesehen.

Das fehlende Wissen um die jeweiligen Anforderungen und Belange der anderen Disziplinen kann dabei zu problematischen Ansichten und Aussagen führen. Am Gerät unzureichend geschulte Restaurator*innen vermögen sich, aufgrund frustrierender und mangelhafter Ergebnisse, schnell zu negativen Äußerung zum Nutzen neuer Technologien für ihre Fachdisziplin hinreißen lassen. Dies spiegelt sich beispielsweise im Titel einer Tagung des Verbands der Restauratoren (VdR) in 2018 wider: „3D - Durchblick oder Datenmüll?"3. Ihnen gegenüber stehen Ingenieur*innen für Photogrammmetrie und Fernerkundung, die gelegentlich hoffen, mit einer neuen technischen Innovation einen aktiven Beitrag zum Erhalt des Kulturerbes leisten zu können, auch wenn die erzielten 3D-Modelle für eine wissenschaftliche Dokumentation und Verarbeitung der Daten im historischen Kontext nicht ausreichend präzise sind. ${ }^{4}$ Bei den genannten Beispielen handelt es sich freilich um Extreme, es soll daher auch auf die sehr erfolgreich funktionierende Kooperation der Fachbereiche verwiesen werden, wie sie zum Beispiel nunmehr seit über 50 Jahren durch CIPA - Heritage Documentation verkörpert wird; einem internationalen Zusammenschluss des International Council of Monuments and Sites (ICOMOS) und der International Society for Photogrammetry and Remote Sensing (ISPRS). ${ }^{5}$

Dennoch zeichnen sich, wie in den oben aufgezeigten Beispielen, Probleme oder Unzulänglichkeiten in der Kommunikation und Zusammenarbeit zwischen den Disziplinen ab. Die vorliegende Arbeit will daher die verschiedenen Disziplinen stärker für einander sensibilisieren, den Dialog zwischen den Akteur*innen fördern und einen Beitrag zum interdisziplinären Diskurs leisten. Sie appelliert dabei,

\footnotetext{
${ }^{3} \mathrm{Vgl}$. <https://www.restauratoren.de/termin/3d-durchblick-oder-datenmuell-2/> letzter Zugriff 21.08.2019.

${ }^{4}$ Fangi et al. 2018, S. 335. Eine Auflösung von $1 \mathrm{~cm}$ pro Pixel bei einer durchschnittlichen Genauigkeit von $8 \mathrm{~cm}$ ist weit von den geforderten Genauigkeiten für eine denkmalgerechte Dokumentation entfernt.

${ }^{5} \mathrm{Vgl}$. <https://www.cipaheritagedocumentation.org/> ; <https://www.icomos.org $>$; $\langle$ https://www.isprs.org/> letzter Zugriff 23.03.2021.
} 
innerhalb des großen Forschungsbereichs der Kulturerbeforschung fächerübergreifend zusammenzuarbeiten, um die jeweiligen Stärken im Sinne des ganzheitlichen Kulturerhalts nutzen und bündeln zu können. Die Ausführungen richten sich dabei verstärkt auf die Wissenschaften, die aktiv mit dem materiellen Erhalt des Kulturerbes vertraut sind, also die Archäologie, Bauforschung, Kunstgeschichte, Denkmalpflege, Restaurierung und Restaurierungswissenschaft. Es soll dabei der Mehrwert und praktische Nutzen moderner Technologien für den analytischen Einsatz in der Kulturerbeforschung als Werkzeug für die Untersuchung und Dokumentation von materiellem Kulturerbe herausgearbeitet und klar dargestellt werden. Der Schwerpunkt liegt dabei auf dem Einsatz von bildgebenden, berührungslosen und zerstörungsfreien optischen Messtechniken. Konkret werden hierbei verschiedene Methoden zur dreidimensionalen Erfassung von komplexen Oberflächen ganzer Bauwerke bis hin zu kleinsten Oberflächendetails im Submillimeterbereich sowie die multispektrale Bildgebung behandelt. Neben der Darstellung von Möglichkeiten und Limitationen bei der Erhebung der Daten, beispielsweise aufgrund der im Kulturgut verwendeten Materialien, werden verschiedene Verfahren zur Auswertung der Datensätze dargestellt. Die Begriffe ,Kulturerbe' und ,Kulturgut' werden in dieser Arbeit synonym für von Menschen geschaffene oder durch sie veränderte Objekte mit kultureller Bedeutung verwendet.

Für ein besseres Verständnis der Anforderungen und Bedürfnisse, welche an eine Technologie im Einsatz zur Untersuchung von Objekten des kulturellen Erbes gestellt werden, erfolgt zunächst in einem ersten Abschnitt die Definition des übergeordneten Forschungsumfeldes der Kulturerbeforschung im Sinne der ,Heritage Science'. Anschließend folgen Definitionen der Begriffe Restaurierungswissenschaft, Konservierung / Restaurierung, Konservierungswissenschaft sowie der Präventiven Konservierung und ihrer Abgrenzung untereinander. Aufgrund der bisherigen Ermangelung an ethischen Grundsätzen für das große Feld der Kulturerbeforschung und passender Richtlinien für eine denkmalgerechte, digitale, dreidimensionale Dokumentation, ${ }^{6}$ werden in dieser Arbeit zudem ethische Leitsätze für die Kulturerbeforschung, unter Anlehnung an die etablierten Vorgaben und Empfehlungen innerhalb der Konservierung und Restaurierung, formuliert. Diese Leitsätze sind dabei als Vorschlag für die Wahrung eines denkmalgerechten Umgangs mit dem Objekt durch alle beteiligten Disziplinen und Akteur*innen zu sehen. Durch sie soll die Notwendigkeit und der Bedarf solcher Richtlinien herausgestellt werden. Sie dienen dabei als Appell an internationale Institutionen wie etwa dem International Council on Monuments and Sites (ICOMOS), dem International Council of Museums (ICOM) und dem International Centre for the Study of the

\footnotetext{
${ }^{6}$ Es existieren verschiedene Richtlinien zur denkmalgerechten Dokumentation (vgl. Eckstein 1999 und BDA 2015), jedoch verweisen sie stets auf Genauigkeitsstufen und Standards von 2D-Plänen. Die zusätzlichen Möglichkeiten einer dreidimensionalen Dokumentation werden kaum behandelt, sodass hierzu bisher Richtlinien und Standards fehlen.
} 
Preservation and Restoration of Cultural Property (ICCROM), dem Desiderat fehlender, vereinfachter ethischer Leitsätze für Fachdisziplinen, welche nur zeitweise in der Kulturerbforschung involviert sind, entgegenzuwirken. Frei nach dem einführenden Zitat von Chris Caple ist dabei stets eine einfach verständliche Formulierung der Sachverhalte und Funktionsweisen von Techniken angestrebt, um interessierten Leser*innen aller beteiligten Fachdisziplinen einen Zugang zum Thema zu ermöglichen.

Im anschließenden Kapitel folgt ein Überblick über die in dieser Arbeit verwendeten Untersuchungsund Analysemethoden. Hierbei handelt es sich ausschließlich um bildgebende zerstörungsfreie Dokumentations- und Analysemethoden. An verschiedenen Beispielen wird anschließend die Anwendung dieser Methoden an Objekten des kulturellen Erbes dargestellt, beginnend mit der Dokumentation des heiligen Zahntempels in Kandy, Sri Lanka, als Projekt der Kulturerbeforschung und des internationalen Wissenstransfers. Hier werden die Möglichkeiten einer zeitlich sehr begrenzten Dokumentation eines Denkmalensembles internationalen Rangs bearbeitet, im Kontext seiner kulturellen Nutzung als bedeutender buddhistischer Pilgerort. Thematisch hierauf aufbauend folgt eine ,Best-Practice-Empfehlung' zur Digitalisierung barocker Prunkräume in Deutschland. Das Hauptaugenmerk liegt dabei auf einer optimalen Ausnutzung vorhandener Ressourcen, wie etwa der benötigten Arbeitsschritte, der verwendeten Techniken und dem personellen Bedarf zur Erstellung der Daten und Arbeitsweisen, sowie auf den wissenschaftlichen Möglichkeiten und dem Mehrwert für den Bereich der Kunstgeschichte über das Maß der reinen Dokumentation hinaus.

In einem weiteren Kapitel werden die Möglichkeiten der 3D-Oberflächenvergleiche an zwei Beispielen ausführlich behandelt. Es umfasst zunächst die kunsttechnologische Betrachtung der in Serie produzierten Skulptur Bambino ebreo von Medardo Rosso, gefolgt von dem Einsatz für die Dokumentation historischer Glasoberflächen im Kontext ihrer Restaurierung. Das sechste Kapitel befasst sich mit den Vorzügen des komplementären Einsatzes von hochauflösender Oberflächendokumentation und multispektraler Bildgebung als Methode des Monitorings in der Konservierung.

Die Dokumentation, Nachbearbeitung und Auswertung der Daten bilden den Schwerpunkt des behandelten Forschungsrahmens. Allerdings sind im Umgang mit Objekten des kulturellen Erbes eine lückenlose Dokumentation der durchgeführten Maßnahmen und eine fachgerechte Archivierung der Daten ebenfalls essentiell, damit nachfolgende Forscher diese Ergebnisse nachvollziehen und die Daten nutzen können. Das siebte Kapitel befasst sich daher mit der langfristigen Archivierung von digitalen Datensätzen. Den Schwerpunkt bildet eine erarbeitete Ablagestruktur sowie definierte Dateiformate für die Archivierung von 3D Daten. 
Nachdem in den vorangegangenen Kapiteln verschiedene Varianten für den Einsatz von 3D- und zerstörungsfreien Prüfmethoden vorgestellt wurden, soll im achten Kapitel eine kritische Betrachtung der Möglichkeiten und Grenzen dieser Methoden für die Kulturerbeforschung diskutiert werden. Einen Schwerpunkt wird dabei die Diskussion über die Praktikabilität und den Mehrwert bildgebender zerstörungsfreier Prüfmethoden als Werkzeug der Präventiven Konservierung bilden. 


\section{Wissenschaftliches Forschungsumfeld}

Für eine bessere Einschätzung der Praktikabilität und des Nutzens von bildgebenden zerstörungsfreien Prüfmethoden ist es notwendig, vorab die Fachbereiche, in denen die Methoden zur Anwendung kommen sollen, näher zu definieren. Hieraus lassen sich die Anforderungen an das historische Objekt, die verwendeten Techniken, sowie Möglichkeiten und Grenzen im Einsatz von Techniken und Maßnahmen im Umgang mit dem Kulturerbe erschließen. Die später aufgeführten Anwendungsbeispiele von 3D-Dokumentationstechniken, dreidimensionaler Oberflächeninspektion und multispektraler Bildgebung zeigen dabei sehr anschaulich die vielschichtigen Einsatzmöglichkeiten und Herausforderungen in einer Vielzahl an Wissenschaften, die sich mit Objekten des kulturellen Erbes befassen. Nachfolgend soll daher die Kulturerbeforschung als übergeordnete Disziplin erläutert werden.

\subsection{Kulturerbeforschung/,Heritage Science}

Der Begriff ,Kulturerbeforschung' wird in dieser Arbeit mit dem englischen Begriff ,Heritage Science' gleichgestellt. Diese wiederum wird als Überbegriff für alle Bereiche der Wissenschaft definiert, die sich mit der Erforschung von Kulturerbe befassen. ${ }^{7}$ Hierunter fallen zunächst die traditionellen geisteswissenschaftlich geprägten Disziplinen, wie etwa die Kunstgeschichte, Archäologie, Denkmalpflege, sowie die natur- und ingenieurwissenschaftlich ausgerichteten Fachbereiche der Bauforschung, Restaurierung/Konservierung und Restaurierungswissenschaft. Dies sind allesamt Disziplinen, in denen die Erforschung und der Erhalt von Objekten des kulturellen Erbes im zentralen Mittelpunkt der Wissenschaft stehen und in denen sich die wissenschaftlichen Methoden zwischen den verschiedenen Disziplinen stark ähneln, unabhängig davon, ob historische Gebäude, Skulpturen, Malerei oder archäologische Fundstücke untersucht werden sollen. Darüber hinaus zählen jedoch auch Wissenschaften zur Kulturerbeforschung, die sich vielleicht nur temporär oder zumindest nicht primär mit historischen Objekten befassen, die aber jedoch, je nach Fragestellung, einen deutlichen Mehrwert und gewinnbringenden Beitrag für die Erforschung oder den Erhalt eines kulturellen Objektes liefern können. Hierbei kann es sich unter anderem um Materialwissenschaften, Chemie, (Bau)Ingenieurwesen, und Physik handeln. Darüber hinaus leisten auch die Sozialwissenschaften und Psychologie, hier besonders die Wahrnehmungspsychologie, ihren Beitrag in der Kulturerbeforschung. ${ }^{8}$ Die Kulturerbeforschung verkörpert demnach Artikel 2 der Charta von Venedig:

"The conservation and restoration of monuments must have recourse to all the sciences and techniques which can contribute to the study and safeguarding of the architectural heritage." 9

\footnotetext{
${ }^{7}$ Strlič 2018, S. 7380.

${ }^{8}$ Strlič 2018, S. 7380; Strlič 2015; ICCROM 2018a.

${ }^{9}$ ICOMOS 1964, S. 1.
} 
,Heritage Science' oder Kulturerbeforschung hat ihren Schwerpunkt in der Erforschung, dem Erhalt und der Pflege, dem Management und der Nutzung und Zugänglichkeit kulturellen Erbes, unabhängig davon, ob es sich dabei um materielles oder immaterielles Kulturerbe handelt. ${ }^{10}$ Da sich diese Arbeit mit der Anwendung von optischen Messgeräten zur Untersuchung und Erforschung historischer Objekte befasst, wird der Bereich des immateriellen Kulturerbes im Folgenden nicht weiter behandelt. Nachfolgende Aussagen zur Kulturerbeforschung beziehen sich demnach stets auf materielles Kulturerbe. Ein großes Themengebiet der Kulturerbeforschung umfasst die Erfassung und das Verstehen von (zeitgenössischen und historischen) Veränderungen des Objektes, um es nachhaltig schützen und bewahren zu können. Hierzu muss die materielle und strukturelle Zusammensetzung des jeweiligen Kulturerbes verstanden und interpretiert werden können. Eine sichere Interpretation bedarf dabei zwingend der interdisziplinären Zusammenarbeit zwischen den geistes- und naturwissenschaftlichen Disziplinen. ${ }^{11}$ Alleingänge einzelner Disziplinen können in der Interpretation von Veränderungen eines historischen Objekts zu Falschaussagen führen. Auf der geisteswissenschaftlichen Seite fehlt in der Regel das detaillierte Wissen und die Möglichkeiten des Nachweises über die Zusammensetzung sowie das Alterungsverhalten von Materialien, der naturwissenschaftlich-analytischen Seite hingegen fehlen häufig Kenntnisse in den (historischen) Herstellungstechniken, der generellen Geschichte eines Objektes und seiner kulturellen Wertigkeit in der Gesellschaft.

\subsection{Restaurierungswissenschaft als Teil der Kulturerbeforschung}

Der Schwerpunkt der im Hauptteil behandelten Forschungsfragen ist in der Restaurierungswissenschaft verortet, weshalb es zunächst einer Definition des Fachbereichs bedarf. Hierzu ist in einem ersten Schritt eine Differenzierung der Disziplinen Restaurierung, Konservierung und Konservierungswissenschaften notwendig.

Der Begriff ,Restaurierung' hat im deutschen Sprachgebrauch zwei Bedeutungen: die wissenschaftliche Disziplin der Restaurierung und die praktische Tätigkeit.

Restaurierung als wissenschaftliche Herangehensweise wurde in den 1960er Jahren von Cesare Brandi wie folgt umschrieben:

„Die Restaurierung stellt das methodische Moment des Erkennens eines Kunstwerkes dar, in seiner materiellen Beschaffenheit und in seiner historischen Bipolarität in Hinsicht auf seine Vermittlung an die Zukunft." 12

\footnotetext{
${ }^{10} \mathrm{Vgl.} \mathrm{ICCROM} \mathrm{2018a.}$

${ }^{11}$ Strlič 2018, S. 7380.

12 Brandi 2006, S. 44. Der Originaltext von Brandi stammt von 1963; hier wird die deutsche Übersetzung von Ursula Schädler-Saub und Dörthe Jakobs verwendet.
} 
Als wissenschaftliche Disziplin liegt der Schwerpunkt der Restaurierung demnach in der Erfassung der materiellen Zusammensetzung sowie der Veränderungsgeschichte eines Kunstwerkes, mit dem Ziel, praktische Maßnahmen für seine Erhaltung und Bewahrung für die Zukunft vorzunehmen. ${ }^{13}$ Hierzu bedient sich die Restaurierung der Zusammenarbeit mit diversen anderen Feldern der Wissenschaft. So führt Katrin Janis in ihrer Definition der Restaurierung als Wissenschaft daher den Begriff „Transdisziplin“ an:

„Transdisziplin bedeutet in diesem Kontext, die Grenzen des eigenen Faches nicht als Barriere zu verstehen, sondern diese durchlässig zu halten. Die Grenzüberschreitung gehört unmittelbar dazu. Je nachdem, ob es um ein gemeinsames Projekt der Erforschung eines Kulturgutes, um die Entwicklung neuer Materialien und Techniken oder um die Untersuchung der Folgen soziopolitischer Veränderungen geht, wenden sich die Restauratoren mehr oder weniger intensiv an andere Disziplinen zu und kooperieren mit ihnen. Die Restaurierungswissenschaft [gemeint ist die Restaurierung und Konservierung als Wissenschaftsdisziplin, nicht die Restaurierungswissenschaft - Anmerkung des Verfassers] als Transdisziplin darf man sich demnach nicht als ein für allemal festumrissenes Feld vorstellen. Die Erweiterung des engeren Kerns durch andere Disziplinen erfolgt jeweils in Abhängigkeit von den zu lösenden Aufgaben und ist deshalb nicht selten zeitlich befristet. ${ }^{\text {"14 }}$

Rainer Drewello orientiert sich an der Definition der European Confederation of Conservator-Restorers' Organisation (E.C.C.O.) $)^{15}$ und nennt vier Kernebereiche als Aufgabenfeld der Restaurierung: „1. Die wissensbasierte Bestandsaufnahme; 2. Die technische Basis: das Konservieren; 3. Die eigentliche Kernaufgabe: das Restaurieren; 4. Prävention als notwendige Randbedingung ". ${ }^{16}$ Hier wird also innerhalb der Restaurierung als Fachdisziplin zwischen dem Restaurieren und Konservieren als Tätigkeiten unterschieden. Im weiteren Verlauf wird die wissenschaftliche Disziplin daher zusammenfassend als Restaurierung und Konservierung oder als Restaurierung/Konservierung bezeichnet, so wie es sich auch in den Bezeichnungen der zugeordneten Studiengänge widerspiegelt. ${ }^{17}$ Im Englischen ist die Unterteilung zwischen den praktischen Anwendungen und der Definition der

\footnotetext{
${ }^{13} \mathrm{Vgl}$. Schädler-Saub 2006, S. 25: „Restaurierung heißt also zuallererst, die methodisch richtige Vorgehensweise zu wählen. Erst in einem zweiten Schritt stellt sich die Frage, wie man diese Vorgehensweise technisch am besten umsetzt, welche äußeren Bedingungen zu berücksichtigen sind usw. Die Restaurierung wird damit als praktisch handelnde Kunstkritik aufgefasst, die das Kunstwerk als historisches und ästhetisches Zeugnis in seiner materiellen Beschaffenheit, d.h. in seinem Erhaltungszustand erkennt und für die Zukunft bewahren will. Genau darin liegt der verpflichtende ethische Anspruch an das Verhalten des Menschen gegenüber dem Kunstwerk und an die Restaurierung".

${ }^{14}$ Janis 2005, S. $84 f$.

${ }^{15} \mathrm{Vgl}$. E.C.C.O. 2002, (in der ersten Ausführung 1993 erschienen).

${ }^{16}$ Drewello 2011, S. 277.

${ }^{17} \mathrm{Vgl}$. Beschreibung zum Studium der Konservierung und Restaurierung auf der Seite des Verband der Restauratoren (VdR) <https://www.restauratoren.de/beruf/ausbildung/studium/> letzter Zugriff 16.07.2019; und der Liste der Studiengangbezeichnungen für Restaurierung und Konservierung auf der Seite der Bundesagentur für Arbeit:

$<$ https://berufenet.arbeitsagentur.de/berufenet/faces/index;BERUFENETJSESSIONID=YfL6Kc370GrMFNbmj63eYMrG6b0kF8atCquDOIhIS5kVjYl1wxl!-1761904797?path=null/kurzbeschreibung\&dkz=94064> letzter Zugriff 16.07.2019.
} 
Fachdisziplin eindeutiger. Hier werden die Tätigkeiten als restoration und preservation definiert, die Fachdisziplin hingegen als conservation. Vom Australian Institute for Conservation of Cultural Material (AICCM) wird conservation treffend wie folgt zusammengefasst:

"CONSERVATION: The conservation profession is responsible for the care of cultural material. Conservation activities may include preservation, restoration, examination, documentation, research, advice, treatment, preventive conservation, training and education." 18

Neben der wissenschaftlichen Disziplin gibt es demnach die Restaurierung als Tätigkeit. Dem Zeitgeist und den zum Teil extremen Eingriffen in die Substanz geschuldet, vergleicht Georg Dehio 1905 die Restaurierung als Tätigkeit äußerst kritisch mit der Denkmalpflege und umschreibt sie wie folgt:

„Die Denkmalpflege will Bestehendes erhalten, die Restaurierung will Nichtbestehendes wiederherstellen. Der Unterschied ist durchschlagend. Auf der einen Seite, die vielleicht verkürzte, verblaßte Wirklichkeit, aber immer Wirklichkeit - auf der anderen Fiktion. Hier wie überall hat die Romantik den gesunden Sinn des konservativen Prinzips verfälscht. Man kann eben nur konservieren was noch ist - >was vergangen, kehrt nicht wieder<. "19

Von Brandi wird im Jahr 1963 die Restaurierung als Tätigkeit bereits deutlich liberaler und funktionsorientierter definiert:

"Unter Restaurierung versteht man im Allgemeinen jede Art von Maßnahme, die darauf zielt, einen von Menschen gefertigten Gegenstand wieder funktionstüchtig zu machen. ${ }^{\text {"20 }}$

Im Code of Ethics and Code of Practice des AICCM folgen deutlich konkretere Angaben was eine Restaurierung ist und wie sie erfolgen sollte:

"RESTORATION: The treatment of cultural property through minimal intervention to enhance its interpretation. Restoration may involve the reassembly of displaced components, removal of extraneous matter, or re-integration using new materials." ${ }^{21}$

Hier findet sich also ein klarer Appell dahingehend, dass die Eingriffe in das historische Objekt minimal sein sollten. Darüber hinaus wird das Zusammenfügen von einzelnen Teilstücken unter Zuhilfenahme neuer Materialien sowie das Entfernen von Fremdmaterialien als Teil der Restaurierung genannt. Dies deckt sich mit Salvador Muñoz Viñas' Definition der Restaurierung in seiner Contemporary Theory of Conservation:

"[...] to restore something means to return it to a former state. [...] the objective of many restorations is only to attempt to return the object to a better, less damaged state. It would be

\footnotetext{
${ }^{18}$ AICCM 2002, S. 2.

${ }^{19}$ Dehio 1905, S. $274 \mathrm{f}$.

${ }^{20}$ Brandi 2006, S. 43.

${ }^{21}$ AICCM 2002, S. 2.
} 
preferable to talk about a 'preceding' state, which may not be the state the object was in when it was originated."22

Muñoz Viñas spricht von der Wiederherstellung eines früheren, weniger zerstörten Zustands. Er merkt aber auch an, dass es sich dabei nicht um den Urzustand des Objektes handeln muss; die Historie und Nutzungsgeschichte des Objektes darf und sollte dementsprechend erhalten bleiben. Drewello nennt einen klaren Zweck in seiner Beschreibung der Restaurierung:

„[...] versteht sich die Restaurierung primär als manuelle Tätigkeit, erfordert [diese] handwerkliche Kompetenz und muss notwendigerweise handgreiflich werden, um Substanz zu erhalten und verlorene Sinnbezüge wieder lesbar zu machen. ${ }^{\text {"23 }}$

Neben der reinen Erhaltung der Substanz sollen mit Hilfe der praktischen Restaurierung also Sinnbezüge wiederhergestellt werden. Hierbei muss es sich nicht zwingend um die Wiederherstellung der Funktionstüchtigkeit, wie es Brandi noch definiert hat, handeln, vielmehr soll der Eingriff der Restaurierung helfen, das historische Objekt in seiner Funktion und in seinem früheren Nutzen und seinem Inhalt wieder zu verstehen, wenn dies zuvor durch Überformungen und/oder Alterungs- und Schadensprozesse verunklärt wurde.

Neben der praktischen Restaurierung steht die Konservierung als weitere Tätigkeit in der Fachdisziplin Restaurierung und Konservierung. Sie wird im englischen Sprachgebrauch als preservation bezeichnet und vom AICCM definiert als:

"PRESERVATION: The protection of cultural property through activities that minimize chemical and physical deterioration and damage, and that prevent loss of information. The primary goal of preservation is to prolong the existence of cultural material." 24

Muñoz Viñas definiert preservation ebenfalls sehr treffend:

"[...] 'preservation' means to keep something as it is, without changing it in any way. [...] Preservation is more perfectly defined not by its effect, but its goals. [...] 'Preservation has the goal of extending the life expectancy of cultural heritage' [after Guillemard 1992]"25

Drewello schließt sich diesen Definitionen an und beschreibt die Konservierung als zweiten Kernbereich der Restaurierung, ${ }^{26}$ der technischen Basis, wie folgt:

„Im Zentrum des manuell-technischen Restaurierens [Konservierens; Anmerkung des Verfassers] steht die substanzielle Erhaltung des Status quo. Dabei haben substanzerhaltende und schadensvorbeugende Maßnahmen oberste Priorität. [...] An die Auswahl und Verwendung

\footnotetext{
22 Muñoz Viñas 2011, S. $16 f$.

${ }^{23}$ Drewello 2019, S. 83.

${ }^{24}$ AICCM 2002, S. 2.

${ }^{25}$ Muñoz Viñas 2011, S. $15 f$.

${ }^{26}$ Gemeint als Fachdisziplin Restaurierung/Konservierung.
} 
von Konservierungsmaterialien und -methoden werden dabei besondere Maßstäbe angelegt. Schlüsselanforderung sind Reversibilität und Risikominimierung. ${ }^{27}$

Das Konservieren geht demnach in der Ausführung seiner Maßnahmen nicht so weit, wie das Restaurieren von Kulturerbe. Es geht hier um die reine Erhaltung der historischen Substanz sowie dem Aufhalten und Vorbeugen von Schadensprozessen. Das, Wiederlesbarmachen' von Sinnbezügen sowie die Vermittlung und das Verstehen der ursprünglichen Nutzung des Kulturerbes stehen dabei nicht im Fokus einer Konservierung.

Aufgrund des deutlich geringeren Eingriffs in das Kulturerbe ist eine Konservierung allgemein der Restaurierung vorzuziehen. Dies hat auch bereits Dehio mit seiner Losung „nicht restaurieren - wohl aber konservieren ${ }^{\prime 28}$ deutlich gefordert. Er schreibt weiter:

„Nach dieser Zweckunterscheidung ist jede einzelne Maßregel zu beurteilen. Man konserviere, solange es irgend geht, und erst in letzter Not frage man sich, ob man restaurieren will."29

Mit diesem Appell lieferte Dehio bereits einen ersten Grundstock, auf dem sich später die ethischen Grundsätze der Restaurierung und Konservierung entwickelt haben. ${ }^{30}$

Für eine objektgerechte Konservierung und Restaurierung muss vor den praktischen Tätigkeiten für den Erhalt zunächst das Objekt in seiner materiellen Zusammensetzung, seiner Schadensphänomene und dem kunst- und kulturgeschichtlichen Kontext verstanden werden. ${ }^{31}$ Hierzu können besonders die dreidimensionalen Messtechniken und die Multispektrale Bildgebung einen aktiven Beitrag leisten. ${ }^{32}$ Für die Erfassung der Korrosionsgeschichte und der verwendeten Werkstoffe bedient sich die Restaurierung und Konservierung zweier („Hilfs-“)Wissenschaften; der Restaurierungswissenschaft und der Konservierungswissenschaft.

Die Konservierungswissenschaft definiert ihren Schwerpunkt dabei stark naturwissenschaftlich in der Prävention und Optimierung von dem Kulturgut umgebenden Rahmenbedingungen sowie der gezielten Weiterentwicklung von Möglichkeiten der Objektkonservierung für die Restauratoren, ohne dabei selbst direkt am Objekt tätig zu werden. ${ }^{33}$ Die Restaurierungswissenschaft hingegen wird fachlich zwischen der praktischen Restaurierung und Konservierung sowie der Konservierungswissenschaft eingeordnet:

\footnotetext{
27 Drewello 2011, S. 279.

${ }^{28}$ Dehio 1905, S. 274.

${ }^{29}$ Ebenda.

${ }^{30}$ Vgl. Kapitel 2.4 Ethische Grundsätze der Kulturerbeforschung, S. $14 \mathrm{ff}$.

${ }^{31}$ Drewello 2011, S. $278 f$.

${ }^{32}$ Vgl.: Kapitel 5 Hochauflösende 3D-Oberflächen, S. 83ff, Kapitel 6 Opto-Technical Monitoring - 3D-Techniken und multispektrale Bildgebung, S. $127 \mathrm{ff}$ sowie Kapitel 8 Übergreifende Diskussion, S. $160 \mathrm{ff}$.

33 Drewello 2019, S. 83.
} 
„[Die Restaurierungswissenschaft umfasst Profilbereiche], die sich unter den Oberbegriffen Objektdokumentation, Materialanalyse und Kulturtechniken zusammenfassen lassen. Im Mittelpunkt steht in jedem Fall das Einzelobjekt, sei es ein Bauwerk oder museales Exponat, ein Gegenstand der Kulturgeschichte oder ein archäologisches Fundstück. [...] Restaurierungswissenschaftler sind als Interpretatoren von Objekten in all ihren Ausprägungen unter Nutzung unterschiedlicher Instrumente zu verstehen. ${ }^{34}$

Die zu bearbeitenden Fragestellungen werden dabei in der Regel nicht primär von der Restaurierungswissenschaft selbst definiert, vielmehr stammen sie aus ganz unterschiedlichen Nachbardisziplinen im Umfeld der Kulturerbeforschung. Ein Schwerpunkt der Zusammenarbeit ist mit Sicherheit in dem Bereich der Restaurierung und Konservierung zu finden, aber auch in anderen Fachdisziplinen, die sich aktiv mit der Erforschung von Objekten des kulturellen Erbes befassen - hier besonders die Kunstgeschichte, Bauforschung und Archäologie. Sie suchen mit Hilfe der Restaurierungswissenschaft Antworten auf zumeist kunsttechnologische, diagnostische und werkstoffkundliche Fragen. ${ }^{35}$

\subsection{Präventive Konservierung}

Bei der Präventiven Konservierung handelt es sich um einen der Grundpfeiler der Restaurierung und Konservierung. ${ }^{36}$ Bereits Brandi äußerte sich zur Präventiven Konservierung, bezeichnete sie jedoch als präventive Restaurierung; er formulierte eine erste Definition und stellte ihre außerordentliche Bedeutung wie folgt dar:

„Die präventive Restaurierung bedeutet Schutz, Abwendung von Gefahren und Garantie von günstigen Bedingungen. ${ }^{137}$

„Die präventive Restaurierung ist unter Umständen noch verpflichtender, wenn nicht sogar noch zwingender als konservatorische Notfallmaßnahmen, weil die Prävention eben darauf ausgerichtet ist, den Notfall zu verhindern, der eine vollständige Rettung und Erhaltung des Kunstwerkes im Allgemeinen erschwert.

Wenn man diese Vision von Restaurierung mit trägt, dann muss das größte Engagement einer Person oder Institution, der ein Kunstwerk anvertraut ist, auf die präventive Restaurierung ausgerichtet sein. ${ }^{138}$

Im Bewusstsein der Bedeutung und Wichtigkeit der Präventiven Konservierung wurde zu Beginn der 2000er Jahre das EU-Projekt European Preventive Conservation Strategy Project, kurz: PC-STRAT durchgeführt. Eines der Ergebnisse war die Ausarbeitung eines europaweiten Strategieprogrammes

\footnotetext{
${ }^{34}$ Drewello 2019, S. 83.

35 Drewello 2011, S. 290.

${ }^{36}$ Vgl.: E.C.C.O. 2002 und Drewello 2011, S. 277.

37 Übersetzung aus: Merzenich 2005, S.1 und dort verwiesen auf den Originaltext: „restauro preventivo come tutela, rimozione di pericoli, l'assicurazione di condizioni favorevoli“, aus: Brandi 1956, S. 87f.

${ }^{38}$ Brandi 2005, S. $88 f$.
} 
für Museen, dem sogenannten Vantaa Document. ${ }^{39}$ In ihm wurden fünf Hauptthemen der Präventiven Konservierung als Rahmen definiert, welche die Regierungen der Länder an oberste Stelle der Verantwortung für die Umsetzung eines Strategieplans setzen. Um die Ziele umzusetzen sollten Museen notwendige Maßnahmen der Präventiven Konservierung einleiten, das Thema im Rahmen des Studiums an Restauratoren umfassend vermittelt werden, allen Beteiligten Zugang zu Informationen über den Themenbereich der Präventiven Konservierung ermöglicht werden und darüber hinaus sollte die Öffentlichkeit in das Thema mit involviert werden. ${ }^{40}$ Klare Strategien, Empfehlungen für Maßnahmen und eine grundlegende Definition der Präventiven Konservierung finden sich allerdings nicht in dem Dokument. Zudem richtet es sich ausschließlich an Sammlungen und Museen - die Denkmalpflege bleibt außen vor.

Sowohl in der Definition der E.C.C.O. als auch des AICCM wird die Präventive Konservierung als Durchführung schadensvorbeugender Maßnahmen für das Kulturerbe durch die Kontrolle und Optimierung umgebender Umweltparameter (Klimakontrolle und Schadstoffvermeidung) definiert. ${ }^{41}$ Dem schließt sich auch Drewello an. ${ }^{42}$ Doch umfasst die Präventive Konservierung viel mehr. Eine deutlich ausführlichere und grundlegende Definition liefert Andreas Burmester:

„Die Präventive Konservierung bündelt eine Vielzahl indirekter, auf den dauerhaften Erhalt von Kulturgut ausgelegte Maßnahmen und bemüht sich dabei um eine ganzheitliche, interdisziplinär getragene Sicht der Problematik des Erhaltes von Kulturgut. Durch die Schaffung von geeigneten Raumhüllen, verbesserten Klima-, Licht- und Raumluftbedingungen oder der Optimierung von Transportprozessen u. a. trägt sie damit nachhaltig zum Erhalt ganzer Sammlungsbestände oder-komplexe bei. Im Vordergrund steht eine sorgsame Analyse, Bewertung und Minimierung aller Risiken. Die Präventive Konservierung ist ein wirksames und auf lange Sicht wirtschaftliches Mittel, intervenierende direkte Maßnahmen an einzelnen Objekten auf ein Minimum zu reduzieren. Die Präventive Konservierung bindet alle im Umgang mit dem Kulturgut Betraute verantwortlich ein. ${ }^{\text {"43 }}$

Burmester bezeichnet seine Definition als "Dauerbaustelle“, ${ }^{44}$ fordert selbst eine offizielle grundlegende Definition, und fokussiert sich in den anschließenden praktischen Beispielen ausschließlich auf den musealen Bereich. Zu Recht merkt er jedoch anschließend an, dass sich die Präventive Konservierung darüber hinaus auch an die Bereiche der Baudenkmalpflege, der Bodendenkmalpflege, des Landschafts- und des Ensembleschutzes richten müsse. ${ }^{45}$

\footnotetext{
${ }^{39}$ Vantaa Document 2001.

${ }^{40}$ Ebenda, S. $10 \mathrm{ff}$.

${ }^{41}$ Vgl.: E.C.C.O. 2002, S. 2 und AICCM 2002, S. 2.

42 Drewello 2011, S. 283.

${ }^{43}$ Burmester 2004, S. 2 f.

${ }^{44}$ Burmester 2005, S. 4.

${ }^{45}$ Ebenda, S. 4f. und Burmester 2004, S. 2 f.
} 
Die geforderte international gültige Definition der Präventiven Konservierung wurde 2008 durch die Mitglieder des International Council of Museums - Committee for Conservation (ICOM-CC) im Rahmen ihrer $15^{\text {th }}$ Triennial Conference in New Delhi geliefert:

"Preventive conservation-all measures and actions aimed at avoiding and minimizing future deterioration or loss. They are carried out within the context or on the surroundings of an item, but more often a group of items, whatever their age and condition. These measures and actions are indirect - they do not interfere with the materials and structures of the items. They do not modify their appearance.

Examples of preventive conservation are appropriate measures and actions for registration, storage, handling, packing and transportation, security, environmental management (light, humidity, pollution and pest control), emergency planning, education of staff, public awareness, legal compliance." 46

Bei dem Verweis auf ein einzelnes Objekt und der Gruppe von Objekten, spiegelt sich der klare Schwerpunkt von ICOM-CC im musealen Sektor wider. Die Definition wird aber auch vom International Centre for the Study of the Preservation and Restoration of Cultural Property (ICCROM) wortwörtlich übernommen und damit von den reinen Sammlungsobjekten auf das Kulturerbe generell übertragen. ${ }^{47}$ Die Präventive Konservierung umfasst demnach alle Maßnahmen, die Schadensprozesse verhindern oder die ,Lebensdauer' des Kulturerbes verlängern, ohne dabei das Kulturerbe anzurühren oder in irgendeiner Weise zu verändern. Sie grenzt sich ab von aktiven, in das Objekt eingreifenden Maßnahmen, die erfolgen müssen, nachdem ein Schaden am Kulturerbe eingetreten ist ${ }^{48}$ und arbeitet mit passiven, vorbeugenden Maßnahmen. Bei der klassischen Disziplin der Restaurierung und Konservierung handelt es sich also um nachsorgende Aktivitäten, die erst aktiv werden, wenn das Problem schon aufgetreten ist. Die Präventive Konservierung ist dagegen eine vorsorgende Maßnahme und soll dafür Sorge tragen, dass das Kulturgut erst keinen Schaden nimmt.

Wie bereits Burmester anmerkt, betrifft die Ausführung solcher vorbeugender Maßnahmen nicht ausschließlich Restauratoren. ${ }^{49}$ Für den musealen Sektor wurde daher in den letzten Jahren eine Handreichung von ICOM Deutschland erarbeitet, die leicht verständlich alle Beteiligten im Umgang mit Kulturgut bei der Reduktion von potentiellen Schadensquellen unterstützen soll. Es wird dort unter anderem über den Umgang mit physikalischen Kräften, die auf das Objekt einwirken können, Diebstahl, Schadstoffvermeidung und der Optimierung von Temperatur und relativer Luftfeuchte informiert. ${ }^{50}$ Die Vereinigung der Landesdenkmalpfleger (VDL) hat eine vergleichbare Handreichung

\footnotetext{
${ }^{46}$ ICOM-CC 2008, S. 1f.

${ }^{47}$ Siehe ICCROM 2018b.

${ }^{48} \mathrm{Vgl}$. Restaurierung und Konservierung als Tätigkeit (s.o.).

${ }^{49}$ Vgl. Burmester 2004, S. 2f und Burmester 2005, S. 4f.

50 ICOM 2014.
} 
zur Vorsorge, Pflege und Wartung von Baudenkmälern und deren Ausstattung erstellt. ${ }^{51}$ In beiden Fällen geht es darum, auch Laien nahezubringen, wie sie sich objektgerecht um das ihnen anvertraute Kulturerbe kümmern können.

Neben dem ,Sich-Kümmern' - der Wartung und Pflege des Objektes - zählen auch untersuchende Maßnahmen zur Präventiven Konservierung. Für eine ganzheitliche, nachhaltige und objektorientierte Vorsorge ist es notwendig, dass das Objekt in seiner Materie, Veränderungsgeschichte und im Kontext seiner Umgebung verstanden wird. Hierunter sind aber nicht nur reine Analysemethoden zu verstehen, die eine Entnahme von Probenmaterial und damit einen aktiven Eingriff in das Objekt erfordern. Vielmehr sind das genaue Hinschauen und Beobachten gemeint, insbesondere das berührungslose Monitoring. Hierzu zählt neben dem Klimamonitoring, also der langfristigen Aufzeichnung von Temperatur und relativer Luftfeuchtigkeit, das optische Monitoring, denn bereits mit einer Kamera oder einem digitalen USB-Mikroskop können Oberflächen wiederkehrend inspiziert werden um Veränderungen und ggf. den Beginn von Schadensprozessen zu erfassen. Möglichkeiten eines tiefergehenden optischen Monitorings liefert zuweilen die multispektrale Bildgebung oder ein wiederkehrender Vergleich der Oberflächengeometrie. ${ }^{52}$

\subsection{Ethische Grundsätze der Kulturerbeforschung}

Bei der Arbeit mit Objekten des kulturellen Erbes ist stets ein respektvoller und sorgfältiger Umgang zu wahren. Hierzu bedarf es ethischer Grundsätze für die Kulturerbeforschung, derer sich alle beteiligen Personen, Institutionen und Fachdisziplinen bewusst sein und nach denen sie sich richten sollten. Matija Strlič liefert in seiner Einführung in die Kulturerbeforschung einen ersten groben Ansatz, in dem er durch eine naturwissenschaftliche Untersuchung notwendige Eingriffe in die Substanz und zu erwartenden Erkenntnisgewinn gegenüberstellt:

"Heritage Science' [...] fragt nach dem Wie und Warum [...] eigene[r] ethische[r] Richtlinien: Der Schaden an einem Objekt muss vom Informationsgewinn durch die Analyse aufgewogen werden. Die Anschauungen und Werte [...] sind zu berücksichtigen [...]." ${ }^{43}$

Ethische Grundsätze entstehen innerhalb einer Gemeinde oder Gruppe durch die gemeinsame Auffassung und Definition von falschem und richtigem Handeln und Verhalten. Sie liefern demnach eine moralische Basis für Entscheidungsfindungen im Alltag, ohne dabei zwangsläufig als maßregelnde und strafregelnde Gesetze im juristischen Sinne festgeschrieben zu sein. Die einzelnen Mitglieder einer Gemeinschaft können somit selbst entscheiden, wie strikt sie die Grundsätze auffassen, ob als unumstößliche Regeln und Verhaltenskodex oder eher als Orientierungshilfe und Richtlinie. Neuen

\footnotetext{
${ }^{51}$ VDL 2016.

${ }^{52} \mathrm{Vgl}$. Kapitel 6 Opto-Technical Monitoring - 3D-Techniken und multispektrale Bildgebung, S. $127 \mathrm{ff}$.

${ }^{53}$ Strlič 2018, S. 7380.
} 
Mitgliedern einer Gemeinde werden die bewährten Grundsätze durch Vermittlung oder zuweilen ,Indoktrination' wie etwa durch familiäre und schulische Erziehung nahegebracht. ${ }^{54}$

In der Kulturerbeforschung vereinen sich unterschiedliche Fachdisziplinen und Wissenschaften mit ganz eigenen Grundsätzen und Moralvorstellungen. Die Formulierung von Strlič, auch wenn sie im Grunde stimmig ist, verallgemeinert das Problem dementsprechend zu sehr. Im Nachfolgenden soll daher versucht werden, gemeinsame ethische Grundsätze der Kulturerbeforschung zu formulieren und dabei bestehende Grundsätze zu adaptieren. Im Zentrum der Betrachtung steht dabei der Erhalt des Kulturerbes für kommende Generationen.

In den Natur- und Materialwissenschaften ist es selbstverständlich, gewisse Mengen an Probenmaterial für eine Analyse im Labor zu entnehmen, zu verbrauchen oder in ihrer Beschaffenheit unwiederbringlich zu verändern. In ihrem Fokus stehen die größtmögliche Aussage sowie das Erzielen eines unverfälschten und präzisen Ergebnisses. Die Human- und Sozialwissenschaften hingegen haben den Menschen im Fokus ihrer Wissenschaft, wodurch in ihrer Arbeit mit Kulturgütern in der Regel keine direkten Eingriffe oder Veränderungen am Objekt erfolgen. Folglich eignen sich weder die Naturwissenschaften noch die Human- oder Sozialwissenschaften für die Formulierung ethischer Grundsätze im Bereich der Kulturerbeforschung. Die Suche sollte demnach von den Wissenschaften ausgehen, die per se aktiv mit historischen und kulturellen Objekten arbeiten.

Die Kunstgeschichte nutzt dabei einen überwiegend geisteswissenschaftlichen Zugang zum Objekt. In der Regel legt sie nicht aktiv Hand an das Forschungsobjekt an. In ihrer Tätigkeit finden also keine verändernden Maßnahmen am Kulturerbe statt. Die Archäologie führt im Rahmen ihrer auswertenden Arbeit ebenfalls keine verändernden Maßnahmen durch. Sofern jedoch aktives Freilegen und Ausgraben von archäologischen Strukturen stattfinden, muss die Archäologie in einigen Aspekten als zerstörende Wissenschaft aufgefasst werden. Es sei dabei zu bedenken, dass die aktive Arbeit an Forschungszentren, Universitäten und anderen wissenschaftlichen Einrichtungen lediglich einen kleinen Teil der archäologischen Tätigkeit ausmacht. Das Hauptaufgabenfeld der Archäologie liegt in der wissenschaftlichen Dokumentation im Zuge von Baumaßnahmen. Die gesicherten und geborgenen Fundstücke sowie die erstellte Dokumentation ihrer Fundumstände und Befunde - also der umgebenden Strukturen in dessen Kontext das Fundgut geborgen wurde - sind nach Beendigung der Baumaßnahme in der Regel das einzige Überbleibsel des eigentlichen Kulturgutes. Natürlich liefert die Archäologie mit der Bergung von Kulturgütern und der Einleitung von Maßnahmen zur Erhaltung (einzelner) Baustrukturen, sowie der Dokumentationsarbeit, einen klaren Beitrag zum Schutz von Kulturgütern sowie ihrer Vermittlung an künftige Generationen. Dennoch sind, bedingt durch die

\footnotetext{
${ }^{54}$ Vgl. Caple 2000, S. 59.
} 
nüchterne Betrachtung der alltäglichen Arbeit, die ethischen Grundsätze der Archäologie nicht umfassend oder zumindest nicht idealistisch genug, um als ethische Grundsätze der Kulturerbeforschung zu dienen. Die Bauforschung kann im Sinne ihrer ethischen Auffassung zwischen der Kunstgeschichte und Archäologie angesiedelt werden. Im Sinne der Englischen ,building archaeology' erfasst, analysiert und dokumentiert sie Strukturen der zumeist aufgehenden, erhaltenen Bausubstanz und kombiniert dabei Werkzeuge der Archäologie mit dem technischen Verständnis der Architektur.

Am ehesten sollten sich die ethischen Grundsätze der Kulturerbeforschung an denen der Restaurierung und Konservierung orientieren. Die Kernaufgabe der Restaurierung und Konservierung liegt in der Durchführung von Maßnahmen mit dem eindeutigen Ziel, Kulturgüter zu schützen und für die Zukunft zu bewahren. Somit kann sie als verteidigende und fürsprechende Instanz der kulturellen Objekte angesehen werden. Da sie zudem, im Rahmen ihrer Tätigkeit, aktiv Hand an die Objekte legen muss und dabei auch unter Umständen ihre Substanz verändert, benötigt gerade die Restaurierung und Konservierung sehr präzise ethische Grundsätze.

Brandi formuliert in den 1960er Jahren in seiner Theorie der Restaurierung Richtlinien für den Umgang mit Kulturgütern und ihrer Restaurierung. ${ }^{55}$ Diese bilden immer noch die Grundlage der später von den Restaurierungsinstituten formulierten Empfehlungen. ${ }^{56}$ Als wichtigsten Punkt merkt Brandi einleitend an, dass sich jeder Akteur*in bewusst sein muss, dass er es in seiner Arbeit mit Kunst- und Kulturgut zu tun hat und nicht mit irgendeinem Objekt. ${ }^{57}$ Bei einer Restaurierung gibt er dabei dem materiellen Substanzschutz einen klaren Vorzug vor anderen Maßnahmen, da Brandi die Materie als gestaltgebendes Element eines Kulturgutes wahrnimmt, durch dessen Schutz eine Bewahrung und Vermittlung an die Zukunft gesichert wird. ${ }^{58}$ Für die Durchführung der Maßnahmen empfiehlt er dabei stets eine umfassende Zusammenarbeit mit allen möglichen beteiligten Wissenschaften ${ }^{59}$ und formuliert zwei Grundsätze:

1. "Man restauriert nur die Materie des Kunstwerkes. "60

2. „Die Restaurierung soll danach streben die potentielle Einheit des Kunstwerkes wieder hervorzustellen, sofern dies möglich ist, ohne eine künstlerische oder eine historische Fälschung zu begehen und ohne die vielfältigen Spuren der Zeit am Kunstwerk zu tilgen. "61

\footnotetext{
${ }^{55}$ Vgl. Brandi 2006.

${ }^{56}$ Siehe unten.

${ }^{57}$ Brandi 2006, S. 44.

${ }^{58}$ Ebenda, S. 44f.

${ }^{59}$ Ebenda, S. 45.

${ }^{60}$ Ebenda.

${ }^{61}$ Ebenda, S. 46.
} 
Brandi definiert restauratorische und konservatorische Eingriffe als historisches Ereignis, das sich in die fortlaufende Geschichte des Kulturerbes einfügt und verlangt, dass alle am Objekt vorgenommenen Maßnahmen wahrgenommen werden können und sich von der historischen Substanz unterscheiden lassen sollen. ${ }^{62}$ Er plädiert ferner dafür, jedes kulturelle Objekt als Einzelstück wahrzunehmen und, darüber hinaus, dass seine Restaurierung und Konservierung als Einzelfall durchzuführen ist. Er warnt damit vor der Gefahr einer unsachgemäßen Maßnahme aufgrund von gleichförmigen, standardisierten Arbeitsabläufen. ${ }^{63}$ Brandi ermahnt zudem, nicht willkürlich Maßnahmen im Sinne einer Restaurierung oder Konservierung zu beginnen, sondern zunächst abzuschätzen, ob ein Eingriff tatsächlich notwendig ist, da sonst ein möglicher Verlust des Kunstwerkes droht. ${ }^{64}$ Wenn festgestellt wird, dass eine Maßnahme zwingend notwendig ist, empfiehlt er drei Richtlinien für vorbereitende Untersuchungen, um eine möglichst erfolgversprechende Restaurierung oder Konservierung durchzuführen. Hierbei soll zunächst ermittelt werden, welche Maßnahmen notwendig sind, um das Kunstwerk als solches wieder erlebbar zu machen. An zweiter Stelle zielt er auf die Materialität ab, welche umfassend untersucht werden soll, um sowohl die Zusammensetzung als auch die Veränderungsprozesse der Materialien nachvollziehen zu können, ${ }^{65}$ denn:

„[w]enn man ein seit Generationen verwendetes Material, für das Jahrhunderte lange Erfahrung vorliegt, durch ein anderes ersetzt, kann man gar nicht vorsichtig genug sein. "66

An dritter Stelle führt er die Untersuchung der klimatischen Bedingungen an, in denen sich das Objekt befindet, um mögliche schädigende Bedingungen zu reduzieren. ${ }^{67} \mathrm{Er}$ liefert somit bereits erste Grundsteine für die Präventive Konservierung.

Eine Interpretation und Aufarbeitung Brandis Theorie der Restaurierung, unter aktuellen Aspekten der Restaurierung und Konservierung, wurde von Ursula Schädler-Saub geliefert. Sie definiert folgende grundlegenden Erkenntnisse Brandis:

"Allen voran die Erkenntnis, dass die historische und ästhetische Aussage von Kunst- und Kulturgut tatsächlich an den überlieferten materiellen Bestand gebunden ist und dass jeder erneute Eingriff diesen Bestand unweigerlich verändert. Im negativen Fall führt ein solcher Eingriff zu substantiellen Schäden und unwiederbringlichen Verlusten, im positiven Fall zur nachhaltigen Konservierung und respektvollen Weitergabe an zukünftige Generationen. "68

\footnotetext{
62 Brandi 2006, S. 64.

${ }^{63}$ Ebenda, S. 67, S. 89 und S. 104.

${ }^{64}$ Ebenda, S. 70.

${ }^{65}$ Ebenda, S. 89.

${ }^{66}$ Ebenda, S. 115.

${ }^{67}$ Ebenda, S. 89.

${ }^{68}$ Schädler-Saub 2006, S. $35 f$.
} 
Nach den Ansätzen Brandis wurden an vielen nationalen und internationalen Instituten und Verbänden ethische Grundsätze für den Umgang mit historischen Objekten und ihrer Konservierung und Restaurierung verfasst. Den Schwerpunkt dieser ,Codes of Ethics' bilden dabei ganz klar Richtlinien für Kunstobjekte oder Sammlungsobjekte in Museen. Richtlinien für Bauwerke finden sich eher wenige. Vom Verband der Landesdenkmalpfleger gibt es z. B. eine Empfehlung zur Instandhaltung von Baudenkmälern und ihrer Ausstattung, ${ }^{69}$ wobei es sich hier eher um praktische Hinweise zur Durchführung von Pflegemaßnahmen handelt, als um grundsätzliche, ethisch-moralische Leitsätze. Solche finden sich jedoch bereits in der Charta von Venedig. ${ }^{70}$

Aufgrund der Ermangelung an ethischen Grundsätzen für das große Feld der Kulturerbeforschung wird im Folgenden aus existierenden ethischen Grundsätzen der Konservierung und Restaurierung eine relevante Auswahl an ethischen Leitsätzen für die Kulturerbeforschung abgeleitet. Sie bilden dabei eine Synthese aus den wichtigsten, allgemeingültigen bestehenden Grundsätzen, mit dem Ziel, sie für die Kulturerbeforschung weiterzuentwickeln. Diese Leitsätze sind dabei als Vorschlag für die Wahrung eines denkmalgerechten Umgangs mit dem Objekt durch alle beteiligten Disziplinen und Akteur*innen zu sehen. Durch sie soll die Notwendigkeit und der Bedarf solcher Richtlinien herausgestellt werden. Sie dienen als Appell an internationale Institutionen wie etwa ICOMOS, ICOM und ICCROM, dem Desiderat fehlender, vereinfachter ethischer Leitsätze für Fachdisziplinen, welche nur zeitweise in der Kulturerbforschung involviert sind, entgegenzuwirken. Als Grundlage hierzu dienen die Charta von Venedig, ${ }^{71}$ die Professional Guidelines (II) Code of Ethics der European Confederation of ConservatorRestorers' Organisations A.I.S.B.L (E.C.C.O.), ${ }^{72}$ der Code of Ethics for Museums, des International Council of Museums (ICOM), ${ }^{73}$ der Code of Conduct des Institute of Conservations (ICON), ${ }^{74}$ sowie der Code of Ethics and Code of Practice des Australian Institute for Conservation of Cultural Material (AICCM).${ }^{75}$ Folgende allgemeingültige Leitsätze für die Kulturerbeforschung lassen sich definieren:

1. Das Kulturerbe ist als solches zu respektieren, in seiner kulturellen Bedeutung wahrzunehmen und für künftige Generationen zu wahren und zu schützen. ${ }^{76}$

2. Es ist stets Verantwortung für das eigene Handeln zu übernehmen, in dem Bewusstsein, dass mit Kulturerbe gearbeitet wird. ${ }^{77}$

\footnotetext{
${ }^{69}$ VDL 2016.

${ }^{70}$ ICOMOS 1964.

${ }^{71}$ Ebenda.

${ }^{72}$ E.C.C.O. 2003

${ }^{73}$ ICOM 2017.

${ }^{74}$ ICON 2014.

${ }^{75}$ AICCM 2002.

${ }^{76}$ Vgl.: ICOMOS 1964, Präambel und Art. 9, S. 1; E.C.C.O. 2003, Art. 5, S. 2; AICCM 2002, Grundsatz 2, S.3; ICON 2014, Art. 4.2, S. 1; ICOM 2017, Art. 2.18, S. 14.

77 Vgl.: ICOMOS 1964, Präambel, S. 1; E.C.C.O. 2003, Art. 3, S. 1; AICCM 2002, Grundsatz 1, S.3.
} 
3. Maßnahmen sollen auf der größtmöglichen Basis von (fächerübergreifenden) wissenschaftlichen Untersuchungen erfolgen. ${ }^{78}$

4. Der erhaltene Zustand soll stets gewahrt bleiben. Neue Technologien und Materialien dürfen verwendet werden, sofern sichergestellt ist, dass diese nicht schadhaft für die historische Substanz sind. ${ }^{79}$

5. Jegliche Entnahme oder Veränderung von originaler Substanz muss gründlich überlegt und die tatsächliche Notwendigkeit eindeutig begründet sein. ${ }^{80}$

6. Maßnahmen im Sinne der Wartung, Pflege und der Präventiven Konservierung sind notwendig, um langfristig Schäden vorzubeugen. ${ }^{81}$

7. Alle Maßnahmen an einem Kulturerbe sollen ausführlich dokumentiert und angemessen veröffentlicht werden. ${ }^{82}$

8. Die Dokumentationen und alle maßnahmenrelevanten Informationen sind als Zeitdokument zu archivieren. ${ }^{83}$

9. Über diese Grundsätze hinaus muss das eigene Handeln mit den ethischen Richtlinien der eigenen Fachdisziplin vereinbar sein.

In ihrer Kernaussage sind diese Leitsätze einfach, präzise formuliert und konzentrieren sich im Wesentlichen auf zwei Aspekte. Sie zielen darauf ab, dass die Objekte, an denen gearbeitet wird, in der Regel Jahrhunderte oder gar Jahrtausende alt sind und im chronologischen Kontext die aktuelle Tätigkeit nur einen Bruchteil in der Geschichte des Kulturgutes ausmacht. Unter diesem Gesichtspunkt sollte demnach zwingend beachtet werden, dass das Ausmaß einer jeden Tätigkeit in Relation zu ihrer Auswirkung auf das Objekt steht. Sie sollte demnach auf keinen Fall in irgendeiner Art und Weise einen negativen, schädigenden Einfluss auf das Objekt haben. Zudem sollten die Tätigkeiten als Teil der Geschichte und Forschungsgeschichte des Objektes wahrnehmbar und nachvollziehbar sein, sie müssen hierzu hinlänglich dokumentiert und aufgezeichnet werden. Oberstes Gebot dabei ist der Erhalt des Kulturerbes für kommende Generationen.

Besonders Restaurator*innen/Konservator*innen, Vertreter*innen ihrer Nachbardisziplinen und Geistes- und Geschichtswissenschaftler*innen werden diese ethischen Leitsätze voraussichtlich nicht

\footnotetext{
${ }^{78}$ Vgl.: ICOMOS 1964, Art. 2, S.1; E.C.C.O. 2003, Art. 6 und 7, S. 2; AICCM 2002, Grundsatz 3, S. 3 und Art. 5, S. 4, Art. 28, S. 8 und Art. 34, S. 9; ICON 2014, Art. 4.9, S. 2.

${ }^{79} \mathrm{Vgl.:} \mathrm{ICOMOS} \mathrm{1964,} \mathrm{Art.} \mathrm{6,} \mathrm{S.} \mathrm{2;} \mathrm{E.C.C.O.} \mathrm{2003,} \mathrm{Art.} 7$ und 9, S. 2; AICCM 2002, Art. 33,34 und 36, S.9.

${ }^{80}$ Vgl.: ICOMOS 1964, Art. 10, S.2; E.C.C.O. 2003, Art. 8 und 15, S. 2; AICCM 2002, Art. 29 und 31, S. 8.

${ }^{81}$ Vgl.: ICOMOS 1964, Art. 4, S. 2; E.C.C.O. 2003, Art. 8, S. 2; ICOM 2017, Art. 2.23 und 2.24, S. 15; AICCM 2002, Art. 32, S.8.

82 Vgl. ICOMOS 1964, Art. 16, S. 4; E.C.C.O. 2003, Art. 10 und 23 S. 2; ICOM 2017, Art. 2.18, 2.20 und 2.24, S. 14f; ICON 2014, Art. 4.9, S. 2; AICCM 2002, Grundsatz 5, S.3 und Art. 18, S. 7 und Art. 37-41, S. 9 f.

${ }^{83} \mathrm{Vgl.:} \mathrm{ICOMOS} \mathrm{1964,} \mathrm{Art.16,} \mathrm{S.} \mathrm{4;} \mathrm{E.C.C.O.} \mathrm{2003,} \mathrm{Art.} \mathrm{10,} \mathrm{S.} \mathrm{2;} \mathrm{ICOM} \mathrm{2017,} \mathrm{Art.} \mathrm{2.18,} 2.20$ und 2.24, S. 14f; ICON 2014, Art. 4.9, S. 2; AICCM 2002, Art. 37-41, S. 9f.
} 
weit genug gehen oder zu einfach erscheinen. Dennoch wurden sie vom Autor ganz bewusst in einer reduzierten und einfachen Form gehalten. Ashley-Smith hat 2017 eine kritische Arbeit zum praktischen Nutzen der diversen ,Codes of Ethics' der Restaurierung und Konservierung verfasst und dabei sehr eindrücklich aufgezeigt, dass bereits diese Grundsätze den jeweiligen Unterdisziplinen der Restaurierung und Konservierung nicht Genüge tragen. ${ }^{84}$ Dies liegt an der Vielschichtigkeit der Fachdisziplinen und den ganz unterschiedlichen Bedürfnissen der Materialien, mit denen sich die unterschiedlichen Unterdisziplinen der Restaurierung und Konservierung befassen. Er empfiehlt daher die Formulierung von eigenen Grundsätzen und sogenannte ethische Checklisten für die einzelnen Unterdisziplinen wie etwa der Stein-, Holz- oder Papierkonservierung. ${ }^{85}$ Würden aber unter Berücksichtigung der gesamten Bedürfnisse aller Unterdisziplinen die Grundsätze in einem einzigen ,Code of Ethics' zusammengetragen werden, entstünde voraussichtlich ein unüberschaubares Werk, welches sich nicht einfach verstehen und nachvollziehen ließe. Übertragen auf das wesentlich größere Feld der Kulturerbeforschung würde sich dieses Problem weiter potenzieren. Somit bestünde die Gefahr, besonders die Fachbereiche, deren tägliche Arbeit nicht vom Umgang mit Objekten des kulturellen Erbes geprägt ist, davon abzuschrecken, sich überhaupt mit ethischen Grundsätzen zu befassen. Doch besonders den Beteiligten dieser Fachbereiche muss, aufgrund der fehlenden Erfahrung, ein sicherer Umgang mit dem Kulturgut vermittelt werden.

Es sind sich viele Autor*innen, die sich mit der Formulierung oder der Nutzbarkeit ethischer Grundsätze für den Umgang mit Kulturgut auseinandergesetzt haben, einig darüber, dass eine klare Notwendigkeit dieser Grundsätze besteht. ${ }^{86}$ Es genügt demnach nicht, an den gesunden Menschenverstand zu appellieren. Es bedarf einer Grundlage, der sich alle Beteiligten bewusst sind, die sie nachlesen können und an der sie sich im Rahmen ihrer Tätigkeit mit Objekten des kulturellen Erbes orientieren können. In den Leitsätzen eins bis acht wurden daher Aspekte formuliert, die für alle beteiligten Disziplinen gleichermaßen gelten. Somit kann gewährleistet werden, dass Vertreter aus Fachdisziplinen, deren alltägliche Arbeit nicht vom Umgang mit Kulturgut geprägt ist, ebenso verantwortungsbewusst am Objekt arbeiten wie Vertreter der Fachdisziplinen, deren ,täglich Brot' der Erhalt von Kulturerbe ist. Es ist zu hoffen, dass mit diesen Leitsätzen bspw. Vermessungsingenieur*innen mit dem notwendigen Feingefühl für das Kulturerbe ihrer Tätigkeit nachgehen und hierbei sowohl die kulturell geforderten Verhaltensweisen am Objekt beachten, wie mögliche Kleiderordnungen, und zudem aber auch Messpunkte nicht ausschließlich an den vermessungstechnisch günstigsten, sondern an denkmalverträglichen Stellen anbringen, ohne eine

\footnotetext{
${ }^{84}$ Ashley-Smith 2017, S. 2 f.

${ }^{85}$ Ebenda, S. 5 und vgl. Ashley-Smith 1994.

${ }^{86}$ Vgl. Ashley-Smith 1982, 2009, 2017 und 2018; Caple 2000; Muñoz Viñas 2002 und 2011: Janis 2005; Handerson 2011 und Scott 2015.
} 
Schädigung der Oberflächen zu verursachen. ${ }^{87}$ Ferner vermögen Materialwissenschaftler*innen anhand dieser Leitsätze verstehen, warum sie von Restaurator*innen nur kleine Probenmengen für die Analytik erhalten. Mit dem neunten Grundsatz wird darüber hinaus auf die ethischen Grundsätze des jeweiligen Faches verwiesen. Dies zielt insbesondere auf die Fachbereiche ab, deren Tätigkeit sich stärker auf das Kulturgut auswirkt (Restaurierung/Konservierung, Archäologie und Bauforschung etc.) und deren zum Teil in das Objekt eingreifende Arbeit somit intensivere und weiterreichende Grundsätze benötigt, welche zumal häufig bereits formuliert wurden.

Mit den hier dargebrachten ethischen Leitsätzen der Kulturerbeforschung soll eine klar verständliche, einheitliche Basis für eine objektverträgliche Zusammenarbeit geschaffen werden, um zu gewährleisten, dass alle beteiligten Fachbereiche mit der erforderlichen Sorgfalt und dem notwendigen Respekt ihrer Arbeit am Kulturerbe nachgehen können.

Die vorgestellten ethischen Grundsätze bilden die Grundlage aller im Rahmen dieser Dissertation vorzustellenden Praxisbeispiele. Es sei hier besonders auf die Dokumentation des heiligen Zahntempels in Kandy hingewiesen. ${ }^{88}$ Die Arbeiten vor Ort in der Tempelanlage erfolgten ausschließlich zu den regulären Öffnungszeiten des Tempels, sodass ein offener Umgang und eine höchst mögliche Transparenz der durchgeführten Arbeiten im Sinne des ersten Grundsatzes gewährleistet werden konnte. So konnten unmittelbar während der Durchführung der Messungen besorgte Sri Lanker*innen über die verwendete Technik und ihren Mehrwert aufgeklärt werden. Ganz im Sinne von Grundsatz vier zählen die verwendeten Untersuchungs- und Analysemethoden allesamt zu den zerstörungsfreien Prüfmethoden, die zudem keinerlei Berührung des Objektes bedürfen. Somit konnte sichergestellt werden, dass Grundsatz fünf nicht zur Anwendung kommen musste, da keinerlei historische Substanz entnommen, nicht einmal berührt werden musste. Besonders hervorzuheben sei hier der kombinierte Einsatz verschiedener optischer Untersuchungsmethoden durch das OptoTechnical Monitoring, welches ein neues, vielversprechendes Werkzeug für die Präventive Konservierung darstellt. ${ }^{89}$ Die ethischen Grundsätze sieben und acht zur Dokumentation und Archivierung der erhobenen Daten wurden in allen vorgestellten Anwendungen stets gewahrt. Ferner wird in Kapitel sieben eine Grundlage für die kulturerbegerechte Speicherung und Archivierung der Daten - besonders der 3D-Daten - vorgestellt, welche bisher ein ungelöstes Problem der Archive von Museen und Landesämtern darstellte. ${ }^{90}$

\footnotetext{
${ }^{87}$ Sofern eine Anbringung von Messpunkten etwa für eine Deformationsanalyse/Monitoring zwingend am Objekt benötigt werden, sollte die Anbringung in enger Absprache mit den Restaurator*innen abgestimmt, oder besser sogar, durch diese ausgeführt werden, so zum Beispiel im Falle der Bremer Hanse-Kogge: Vgl. Colson 2021; Schmick et al. 2018.

${ }^{88} \mathrm{Vgl}$. Kapitel 4.1. Der Zahntempel - Kulturerbeforschung und Wissenstransfer, S. 44ff.

${ }^{89} \mathrm{Vgl}$. Kapitel 6. Opto-Technical Monitoring - 3D-Techniken und multispektrale Bildgebung, S. $127 \mathrm{ff}$.

${ }^{90} \mathrm{Vgl}$. Kapitel 7. Dokumentation und Archivierung, S. $145 \mathrm{ff}$.
} 


\section{Untersuchungs- und Analysemethoden}

Nachfolgend werden die unterschiedlichen Untersuchungs- und Analysemethoden, welche in den Projektstudien verwendet wurden, eingehend beschrieben. Die vorgestellten und angewendeten bildgebenden zerstörungsfreien Prüfmethoden (non-destructive testing methods - NDTs) stellen dabei nicht das gesamte Repertoire möglicher bildgebender NDTs in der Kulturerbeforschung dar. So seien zusätzlich exemplarisch die optischen Messmethoden der Shearographie, ${ }^{91}$ die thermisch induzierte Mittelwellen-IR-Reflektografie sowie die IR-Thermografie genannt, ${ }^{92}$ welche ebenfalls herausragende Möglichkeiten für die Untersuchung von Kulturgut bieten. Ihre Einsatzmöglichkeiten werden derzeit zum Teil in eigenständigen Promotionsverfahren an der Universität Bamberg bearbeitet, so dass sie hier nicht tiefergehend behandelt werden. ${ }^{93}$

\subsection{Terrestrisches Laserscanning}

Bei dem terrestrischen Laserscanning (TLS) handelt es sich um eine Laser-gestützte Vermessungstechnik für die Erfassung von 3D-Koordinaten. Ihre Möglichkeiten zur Dokumentation von Baudenkmälern und archäologischen Stätten wurde sehr schnell erkannt. Durch die fortschreitende technische Entwicklung und immer größeren Rechenleistungen der Computer und Prozessierungsmöglichkeiten der Scandaten handelt es sich beim TLS daher inzwischen um eine gut etablierte Messtechnik in der Kulturerbeforschung. ${ }^{94} \mathrm{Im}$ technischen Einsatzbereich wird TLS angesiedelt zwischen dem Airborne Laser Scanning (ALS), ${ }^{95}$ für die großflächige Erfassung von Landschaften, und handgeführter Laserscanner zur Vermessung von Kleinobjekten. ${ }^{96}$

Derzeit finden sich zwei Varianten terrestrischer Laserscanner auf dem Markt. So genannte ImpulsLaufzeit-Scanner (pulse-based laser scanner) und Phasen-Vergleichs-Scanner (phase-based laser scanner). ${ }^{97}$ Bei dem Impuls-Laufzeit-Verfahren wird ein kurzer Laserimpuls vom Gerät ausgesendet. Dieser Laserstrahl trifft nach einer gewissen Laufzeit auf die zu vermessende Oberfläche, wird von dort reflektiert und zu einem Empfänger im Gerät zurückgesendet. Durch die Erfassung der Zeit zwischen dem Aussenden und dem Wiedereintreffen des reflektierten Laserimpulses kann die Distanz zwischen dem Scanner und der Oberfläche ermittelt werden (Abb. 01). ${ }^{98}$ Um zudem die relative Lage der

\footnotetext{
${ }^{91}$ Rahrig 2019a, S. $90 f$.

92 Luib 2019a, S. 74ff und Luib 2019b.

${ }^{93}$ Ebenda.

${ }^{94} \mathrm{Vgl}$. Historic England 2018.

${ }^{95}$ Häufig auch als LiDAR-Scanning bezeichnet. Wobei LiDAR für light detection and ranging steht und es sich somit genaugenommen um eine allgemeine Bezeichnung für die lichtbasierte Abstandsmessung, dem Laserscanning, handelt.

${ }^{96}$ Für ALS kommt das Impuls-Laufzeit Verfahren, wie bei einigen TLS, zum Einsatz (siehe unten). Handgeführte Laserscanner funktionieren häufig nach dem triangulations-basierten Verfahren, siehe hierzu Grussenmeyer et al. 2016.

${ }^{97}$ Vgl. Grussenmeyer et al. 2016, S. 311ff; Historic England 2018, S. $7 \mathrm{ff}$.

98 Grussenmeyer et al. 2016, S. 311f.
} 
reflektierten Oberfläche zum Scanner zu ermitteln, müssen zusätzlich zwei Winkel gemessen werden, die sich auf die horizontale und vertikale Achse des Lasers zum Zeitpunkt der Messung beziehen, um so exakte Raumkoordinaten mit jeweils einem Wert für die X-, Y- und Z-Achse zu erhalten. Hierzu wird der Laserimpuls über einen horizontal gelagerten, rotierenden Spiegel ausgesendet (Abb. 02). Durch die Messung der Rotation um die horizontale Achse kann der vertikale Winkel des Laserimpulses erfasst werden. Darüber hinaus rotiert die gesamte Scaneinheit um ihre vertikale Achse, wodurch der horizontale Winkel des Laserimpulses gemessen werden kann. Den Ursprung des Koordinatensystems bildet dabei der Schnittpunkt zwischen der vertikalen und der horizontalen Achse, von dem der Laserstrahl unmittelbar ausgesendet wird. ${ }^{99}$

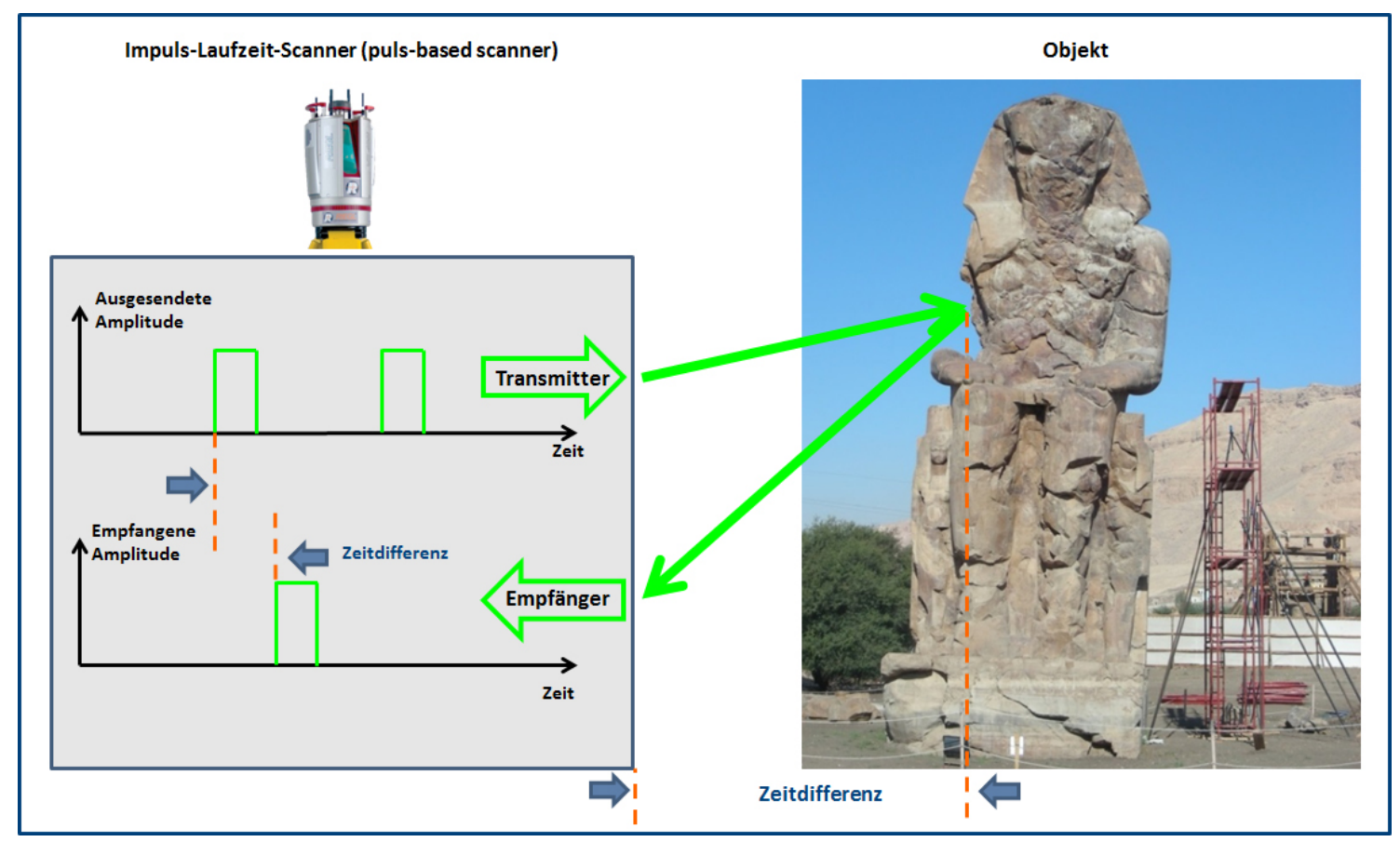

Abb. 01: Funktionsprinzip eines Impuls-Laufzeit-Scanners.

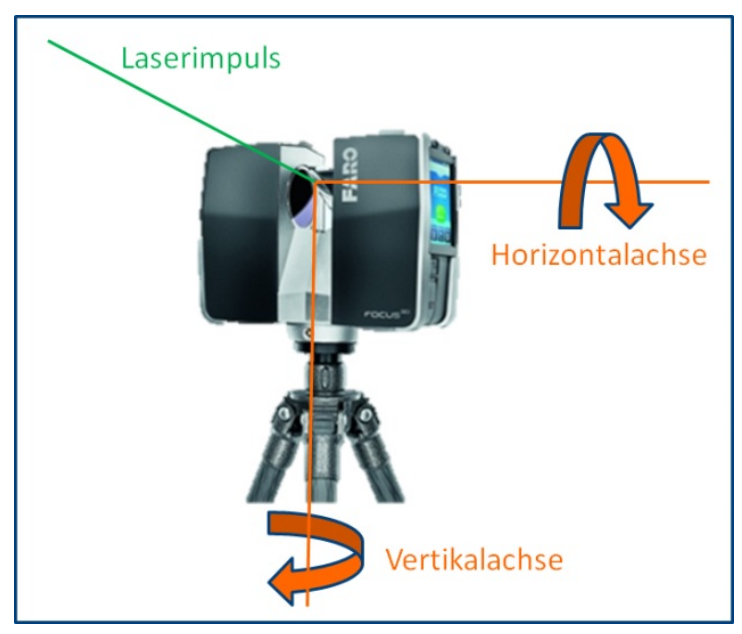

Abb. 02: Lage der Rotationsachsen in einem Laserscanner.

\footnotetext{
${ }^{99}$ Grussenmeyer et al. 2016, S. 306f.
} 
Durch die stetige Messung einzelner Punkte und die fortschreitende Rotation um die beiden Achsen kann Schritt für Schritt die Umgebung um den Scanner herum $360^{\circ}$ horizontal und je nach Modell etwa $270^{\circ}$ bis $300^{\circ}$ vertikal abgetastet und dreidimensional erfasst werden. Je nach Hersteller und Modell weisen die Scanner einen unterschiedlich starken Verschattungsbereich unterhalb des Scanners auf, wodurch sich der eingeschränkte Bereich in der vertikalen Erfassung ergibt. ${ }^{100}$ Dieser tote Winkel, der nicht vom Laserimpuls abgetastet werden kann, begründet sich baubedingt, da die Geräte zumeist auf einem Stativ platziert betrieben werden und nicht in jeder Einzelmessung 3D-Daten des Stativs und des Gehäuses vom Scanner erfasst werden sollen. Zudem haben einige Modelle auch einen Verschattungsbereich auf der Oberseite des Scanners. Dies begründet sich mit Möglichkeiten zur Aufnahme einer separaten Kamera oder eines GNSS/GPS-Empfängers (global navigation satellite system/global positioning system) zur eindeutigen Lagebestimmung des Scanners.

Beim Phasen-Vergleichs-Verfahren werden keine einzelnen Laserimpulse wie beim Impuls-LaufzeitVerfahren ausgesendet. Die Messung erfolgt also nicht Einzelpunkt für Einzelpunkt, vielmehr wird hier ein kontinuierlicher Laserstrahl in einer sinusförmig amplitudenmodulierten Welle ausgesendet (Abb. 03). ${ }^{101}$ Hierdurch werden in kürzerer Zeit deutlich mehr Messsignale ausgesendet und wieder von der Oberfläche reflektiert. Da das einzelne reflektierte Signal aufgrund der Messgeschwindigkeit nur bedingt seinem aussendenden Signal zugeordnet werden kann, erfolgt die Distanzbestimmung in diesem Verfahren durch den Vergleich der Phasendifferenz zwischen ausgesendetem und reflektiertem Signal. Das Phasen-Vergleichs-Verfahren weist somit eine deutlich schnellere Messrate auf. Da jedoch eine wesentlich höhere Energie für die kontinuierliche Messung aufgewendet werden muss, eignet sich dieses Verfahren nur für die Erfassung von Objekten in nicht allzu großer Entfernung. ${ }^{102}$ Nach praktischer Erfahrung des Autors werden in Entfernungen bis etwa 30 Meter Daten in einer denkmalgerechten Auflösung erzielt. Mit dem Impuls-Laufzeit Verfahren kann hingegen auch auf Distanzen von mehreren hundert Metern mit einer gleichbleibenden Genauigkeit gemessen werden. ${ }^{103}$ Beide Verfahren liefern eine Auflösung von etwa 2-5 mm. ${ }^{104} \mathrm{Es}$ ist mit ihnen also möglich, die Topografie oder Struktur einer Oberfläche mit einem Punktabstand von bis zu $2 \mathrm{~mm}$ zu erfassen. Die Wahl des Messverfahrens sollte demnach immer von der Fragestellung und den Anforderungen an

\footnotetext{
100 Grussenmeyer et al. 2016, S. $306 f$.

${ }^{101}$ Ebenda, S. $313 \mathrm{ff}$.

102 Ebenda, S. 314.

${ }^{103}$ Abhängig von der Methode und dem Hersteller liegt die Genauigkeit, mit der die Entfernung eines Punktes zum Scanner ermittelt wird, bei etwa $3 \mathrm{~mm}$. Im Phasen-Vergleichs-Verfahren nimmt die Genauigkeit mit zunehmender Entfernung jedoch deutlich ab, dies hängt mit der Wellenlänge der Messfrequenz zusammen (Vgl. ebenda, S. 315f.).

${ }^{104}$ Der Riegl VZ-400i hat eine Auflösung von etwa 5 mm bei einer Entfernung von 100 m, vgl. Riegl 2019, S. 10; die Leica ScanStation P30/P40 von etwa 6 mm auf 100 m, vgl. Leica 2019, S. 2; die Technischen Datenblätter der Faro Focus Produktreihe sind derzeit nicht frei zugänglich, bei älteren Modellen, wie etwa dem Faro Focus 3D, liegt die Auflösung bei etwa $2 \mathrm{~mm}$ auf $10 \mathrm{~m}$.
} 
den Datensatz abhängig sein. Für die Erfassung von Innenräumen, niedrigen Gebäuden und Höhlen bietet sich ein terrestrischer Laserscanner mit dem Phasen-Vergleichs Verfahren an; bei hohen Gebäudestrukturen, wie Kathedralen und Burgen sowie weitreichenden komplexen Landschaftsstrukturen bietet sich ein Gerät des Impuls-Laufzeit Verfahrens an.

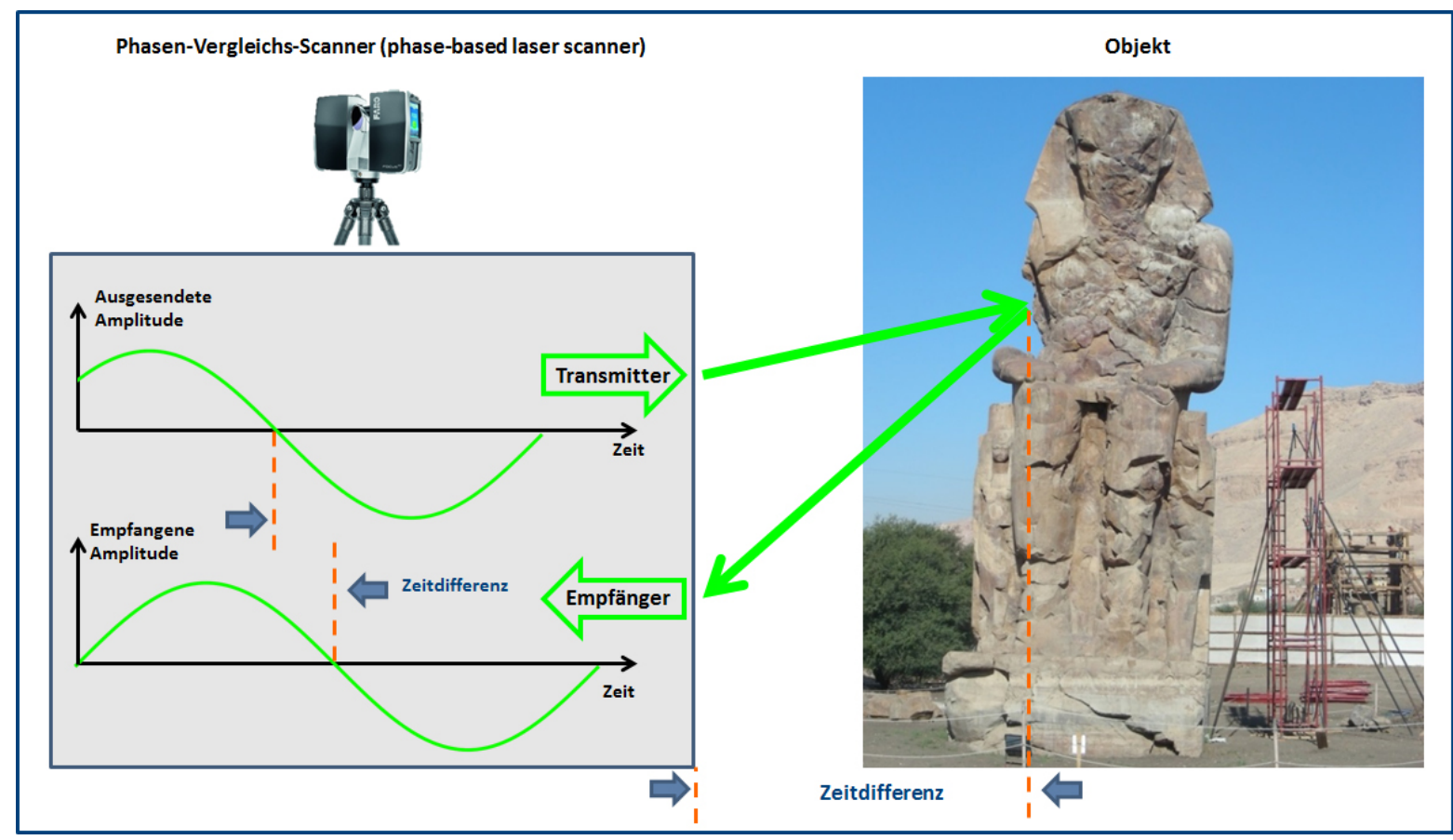

Abb. 03: Funktionsprinzip eines Phasen-Vergleichs-Scanners.

In der Regel verwenden die Hersteller beider Varianten Laser in einem Wellenlängenbereich des nahen Infrarotspektrums, zwischen 700 und $1500 \mathrm{~nm}$. Somit ist der Laserstrahl für das menschliche Auge nicht sichtbar. Es wird zudem keine Farbinformation der Oberfläche mit dem Laser erfasst. In der Darstellung am Computer kann unter anderem die Intensität des reflektierten Laserstrahls als Graustufenbild oder in einem Farbverlauf dargestellt werden (Abb. 04). ${ }^{105}$ Zusätzlich haben die meisten terrestrischen Laserscanner eine Farbkamera, mit der den einzelnen gemessenen Punkten nachträglich ein Farbwert zugewiesen werden kann. Diese Kamera kann entweder im Gehäuse des Scanners integriert sein, wobei sie ebenfalls den rotierenden Spiegel im Zentrum des Scanners nutzt, um alle Bereiche fotografisch erfassen zu können. ${ }^{106}$ Die Geräte mit integrierter Kamera sind meist sehr kompakt und leicht, wodurch ihre Stärken besonders in der Erfassung von engen, schwer zugänglichen Bereichen und, aufgrund des geringeren Transportgewichts, für Einsätze an weit entfernten Orten liegen. Bei diesen Geräten muss jedoch auf eine aufwändige Optik verzichtet werden, wodurch die Bild- und Farbqualität, trotz teils immens hoher Megapixelzahlen, verhältnismäßig gering ausfällt. Daneben gibt es Geräte mit externen Kameras. ${ }^{107}$ Hier werden digitale Spiegelreflexkameras

\footnotetext{
${ }^{105}$ Grussenmeyer et al. 2016, S. 310, Historic England 2018, S. 31.

106 Ebenda.

107 Ebenda.
} 
meist oberhalb des Scanners am Gerät montiert oder sie werden mit besonderen Halterungen für das Stativ nach dem Scanvorgang exakt in der Position des Scanners platziert. Im Betrieb erfordern diese Varianten einen höheren Aufwand an Zeit und Arbeit vor Ort. Da jedoch hochwertige Kameras und Objektive verwendet werden können, ist hier die Bild- und Farbqualität zumeist deutlich gesteigert. ${ }^{108}$

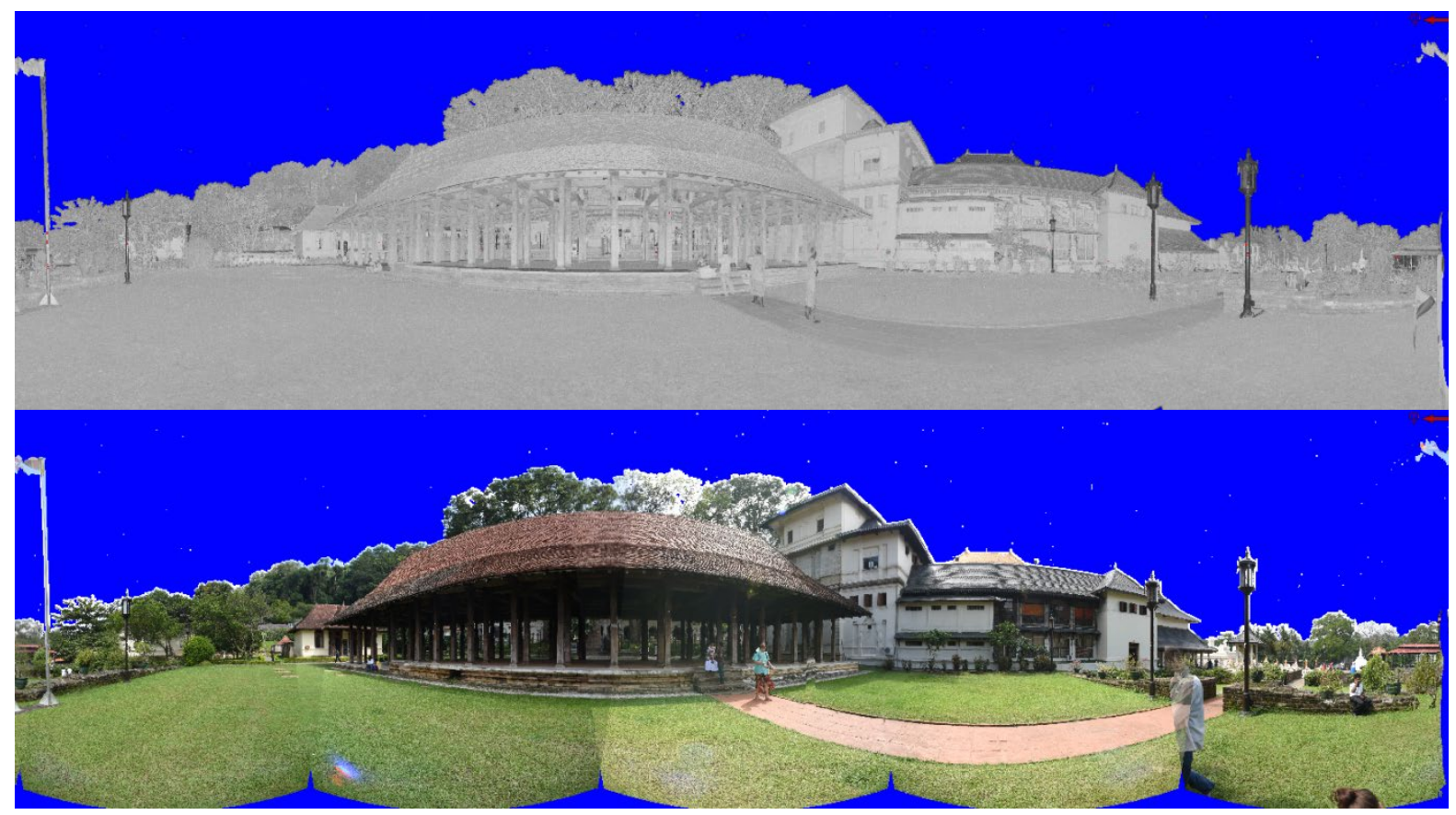

Abb. 04: 2D-Panoramadarstellung eines 3D-Scans. Oben: Darstellung der Reflexion; unten: Darstellung der Farbtextur.

Im Ergebnis liefern beide Varianten des terrestrischen Laserscannings eine Punktwolke (Abb. 05, links), die je nach Reichweite und gewähltem Punktabstand des Scanners eine detailgetreue, dreidimensionale Wiedergabe der, vom Scanner aus sichtbaren, Umgebung enthält. Jedem einzelnen 3D-Punkt ist dabei eine X-, Y- und Z-Koordinate relativ zu dem Ursprung ${ }^{109}$ im Scanner zugeordnet. ${ }^{110}$ Für die vollständige Erfassung eines Objektes sind meist mehrere Standpunkte notwendig (Abb. 05, rechts), die mit Hilfe von Referenzpunkten (Messmarken) oder bestmöglich durch die dreidimensionale Geometrie der einzelnen Punktwolken zueinander ausgerichtet werden. ${ }^{111}$ Eine Punktwolke stellt dabei die Gesamtheit der gemessenen 3D-Punkte eines Einzelscans dar. Durch die Ausrichtung der Punktwolken zueinander werden die Koordinaten der einzelnen 3D-Punkte in ein übergeordnetes Koordinatensystem übertragen. Dies kann durch die Festlegung einer Scanposition als allgemeinen Ursprung erfolgen. Zudem können die Messmarken aber auch mit bekannten

\footnotetext{
108 Vgl. Kapitel 4.2. Der Bamberger Kaisersaal - Neue Möglichkeiten für eine kunsthistorische Analyse historischer Prunkräume, S. 60ff.

109 mit den Koordinaten $X=0,0 ; Y=0,0$ und $Z=0,0$

${ }^{110}$ Grussenmeyer et al. 2016, S. $306 f$.

${ }^{111}$ Für eine nähere Beschreibung der bestmöglichen Ausrichtung über die Geometrie, dem sogenannten bestfit matching oder iterativ closest point matching (ICP) siehe Kapitel 5.2. 3D-Vergleiche für die Oberflächeninspektion und Qualitätskontrolle im laufenden Restaurierungsprozess, S. 107ff.
} 
Vermessungsdaten korreliert werden, wodurch die 3D-Punktwolke zu einem bereits bestehenden Koordinatensystem referenziert werden. Hierzu werden die Koordinaten der 3D-Punkte in das Zielkoordinatensystem transformiert. So kann die Punktwolke zum Beispiel in ein Weltkoordinatensystem georeferenziert werden. ${ }^{112}$ Einige Scanner haben zudem integrierte GNSSSensoren, wodurch eine grobe Georeferenzierung erfolgen kann, oder sie lassen sich mit einem hochpräzisen DGNSS-System ${ }^{113}$ kombinieren, wodurch ihre Position millimetergenau bestimmt werden kann. ${ }^{114}$
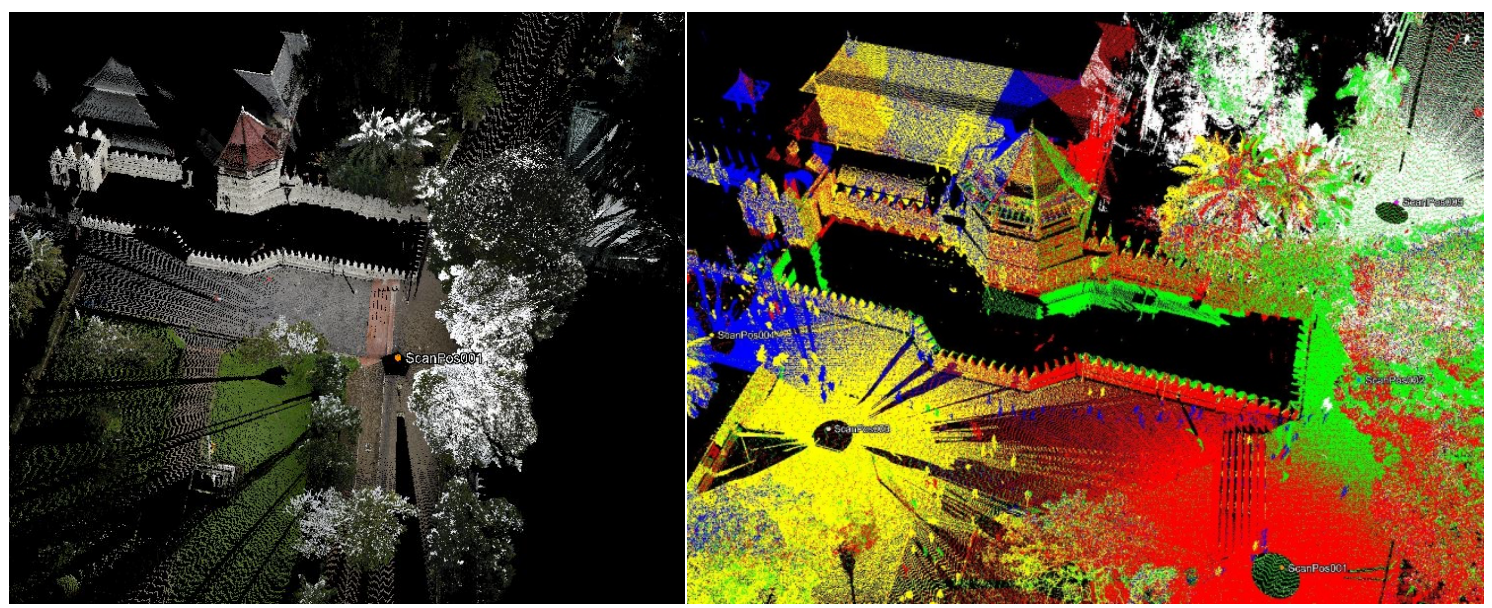

Abb. 05: Links: Bildausschnitt der Punktwolke einer einzelnen Scanposition; rechts: Kombination von fünf Scanpositionen (zur besseren Wahrnehmung wurden den Scanpositionen unterschiedliche Farbwerte zugeordnet).

Im Bereich der Kulturerbeforschung kann TLS für die Dokumentation von komplexen Großobjekten verwendet werden. ${ }^{115}$ Das Einsatzgebiet umfasst besonders den Nutzen als Grundlage für die Erstellung von verformungsgerechten CAD-Plänen als Bestandsdokumentation, wie es unter anderem am heiligen Zahntempel, Sri Dalada Maligawa, in Kandy, Sri Lanka, erfolgt ist. ${ }^{116}$ Die Punktwolken können aber auch in Oberflächenmodelle überführt und mit hochauflösenden farbechten Texturen versehen werden. Diese Modelle bieten dann wiederum die Datengrundlage für historische Gebäudeinformationssysteme (HBIM), die Erstellung von CAD-Plänen und darüber hinaus für die Visualisierung und kunstwissenschaftliche Betrachtung. ${ }^{117}$

\footnotetext{
112 Grussenmeyer et al. 2016, S. 323ff.

113 Differentielles GPS mit externer Referenzstation oder Referenzdienst (wie etwa SAPOS).

${ }^{114}$ Vgl. Riegl 2019; Leica 2019 sowie die Modellreihe Focus von Faro <https://www.faro.com/dede/produkte/bausektor-bim-cim/faro-focus/> letzter Zugriff 06.08.2019)

${ }^{115} \mathrm{Vgl}$. Grussenmeyer et al. 2016, S. 339ff.

${ }^{116}$ Siehe Kapitel 4.1. Der Zahntempel - Kulturerbeforschung und Wissenstransfer, S. 44ff.

${ }^{117}$ Eine detaillierte Beschreibung für die Erstellung von farbechten, texturierten Oberflächenmodellen und ihren Vorzügen in der kunstwissenschaftlichen Betrachtung barocker Prunkräume findet sich in Kapitel 4.2. Der Bamberger Kaisersaal - Neue Möglichkeiten für eine kunsthistorische Analyse historischer Prunkräume, S. 60ff.
} 


\subsection{Structured-Light-Scanning}

Beim Structured-Light-Scanning (SLS) handelt es sich um eine weitere dreidimensionale Messtechnik zur berührungslosen Erfassung von Oberflächen. Ursprünglich wurde dieses Verfahren für die Qualitätskontrolle in der Serienproduktion, vorzugsweise in der Automobilindustrie, entwickelt. ${ }^{118}$ Durch die hochauflösende, dreidimensionale Erfassung der Oberfläche, können die gefertigten Produkte virtuell mit einem CAD-Modell verglichen werden und so selbst geringste Abweichungen zu dem digitalen Idealmodell ermittelt werden. Diese Messtechnik dient somit nicht der Erfassung von Großobjekten, wie ganzer Bauwerken, ${ }^{119}$ sondern Objekten, die maximal ein paar Quadratmeter groß sind. Dafür ist die Auflösung und Messgenauigkeit im Submillimeterbereich bedeutend höher im Vergleich zum TLS.

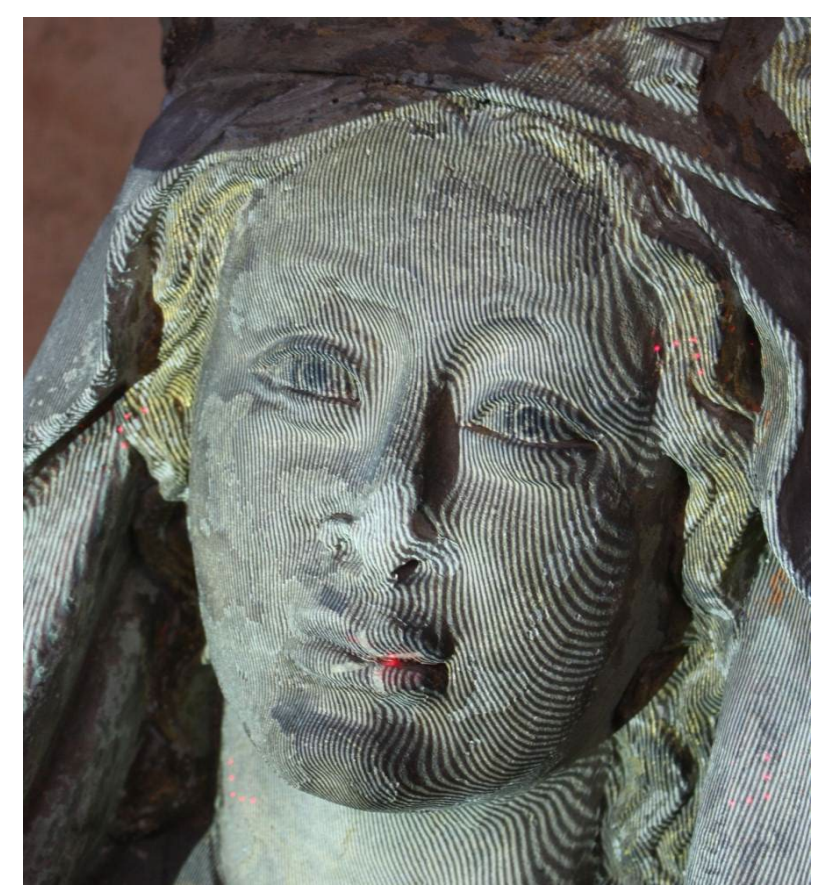

Abb. 06: Projiziertes Streifenmuster eines SLS auf der Skulptur der Muttergottes (um 1260) aus dem Dom zu Meißen.

Im deutschen Sprachgebrauch finden sich die Begriffe (3D-)Weißlicht-Streifenprojektion oder (3D-) Streifenprojektion, die synonym für SLS verwendet werden, jedoch eigentlich nur einen Teilbereich des Structured-Light-Scannings umschreiben. Beim SLS wird durch einen Projektor ein charakteristisches Muster auf die zu digitalisierende Oberfläche projiziert (Abb. 06). Je nach Hersteller kann es sich hierbei um helle und dunkle Streifen, ${ }^{120}$ aber auch um andere Muster aus hellen und dunklen Formen handeln. ${ }^{121}$ Die projizierte Struktur wird wiederum durch eine oder zwei Kameras vom

\footnotetext{
118 Vgl. Gühring 2002, S. 9.

${ }^{119}$ Obwohl es hierzu durchaus Beispiele in der Kulturerbeforschung gibt. So wurde der gesamte Hadrianstempel in Ephesus mit einem SLS dokumentiert; Vgl. Quatember et al. 2012.

${ }^{120}$ Daher der Begriff Streifenprojektion.

${ }^{121}$ Gühring 2002, S. 49ff.
} 
Scanner erfasst. ${ }^{122}$ Essentiell bei dieser Methode ist, dass der exakte Abstand und Winkel zwischen dem Projektor und der Kamera, bzw. zwischen den beiden Kameras, bekannt sind. Projektor und Kamera sind dabei mit Objektiven ausgestatten, deren Fokusbereich sich in einer definierten Distanz vor dem Scanner deckt. Hierdurch ergibt sich ein Dreieck mit den Eckpunkten Projektor, Kamera und dem gemeinsamen Fokusbereich. Da die Lage und Form der projizierten Struktur innerhalb des gesamten Fokusbereichs durch eine photogrammetrische Kalibrierung des Systems bekannt ist, ${ }^{123}$ kann die Oberfläche eines zu vermessenden Objektes entlang der Grenze zwischen den projizierten hellen und dunklen Strukturen ermittelt werden. Die Lageermittlung der einzelnen 3D-Punkte erfolgt vereinfacht gesagt mittels einer Dreiecksberechnung zwischen den bekannten Eckpunkten des Dreiecks (Kamera und Projektor) und der Variablen (Lage des Objektes innerhalb des gemeinsamen Fokusbereichs). ${ }^{124}$ Abbildung 07 zeigt hierzu einen schematischen Aufbau. ${ }^{125}$ Das projizierte Streifenmuster wird während einer Messsequenz verschoben (Phasen-Schiebe-Verfahren), hierdurch werden die einzelnen Punkte mehrfach an der Kante von hellen und dunklen Linien berechnet und somit überbestimmt. ${ }^{126}$ Aufgrund der Phasenverschiebung handelt es sich um ein aktives, scannendes Verfahren. Im Falle eines Stereo-SLS, mit zwei Kameras, wird der gemeinsame Fokusbereich durch die Überschneidung der Fokusbereiche von zwei Kameras und dem Projektor beschrieben. Durch diesen dritten bekannten Eckpunkt erfolgen zeitgleich zwei, beziehungsweise drei, Dreiecksmessungen (zwei jeweils zwischen Kamera-Projektor-Fokusbereich und eine zwischen Kamera-Kamera-Fokusbereich), wodurch der einzelne gemessene 3D-Punkt vielfach ermittelt und so in seiner Lage überbestimmt wird. Durch diese zweite Kontrollmessung wird die Messgenauigkeit erhöht. ${ }^{127}$

\footnotetext{
122 Gühring 2002, S. 14.

${ }^{123}$ Ebenda, S. 37ff.

${ }^{124}$ Genau genommen erfolgt die Berechnung der 3D-Koordinaten durch den photogrammetrischen Vorwärtsschnitt (vgl. Luhmann 2018, S. 335ff und 570ff).

125 Gühring 2002, S. 26ff und 75ff.

126 Luhmann 2018, S. 570ff.

127 Gühring 2002, S. $34 f$.
} 


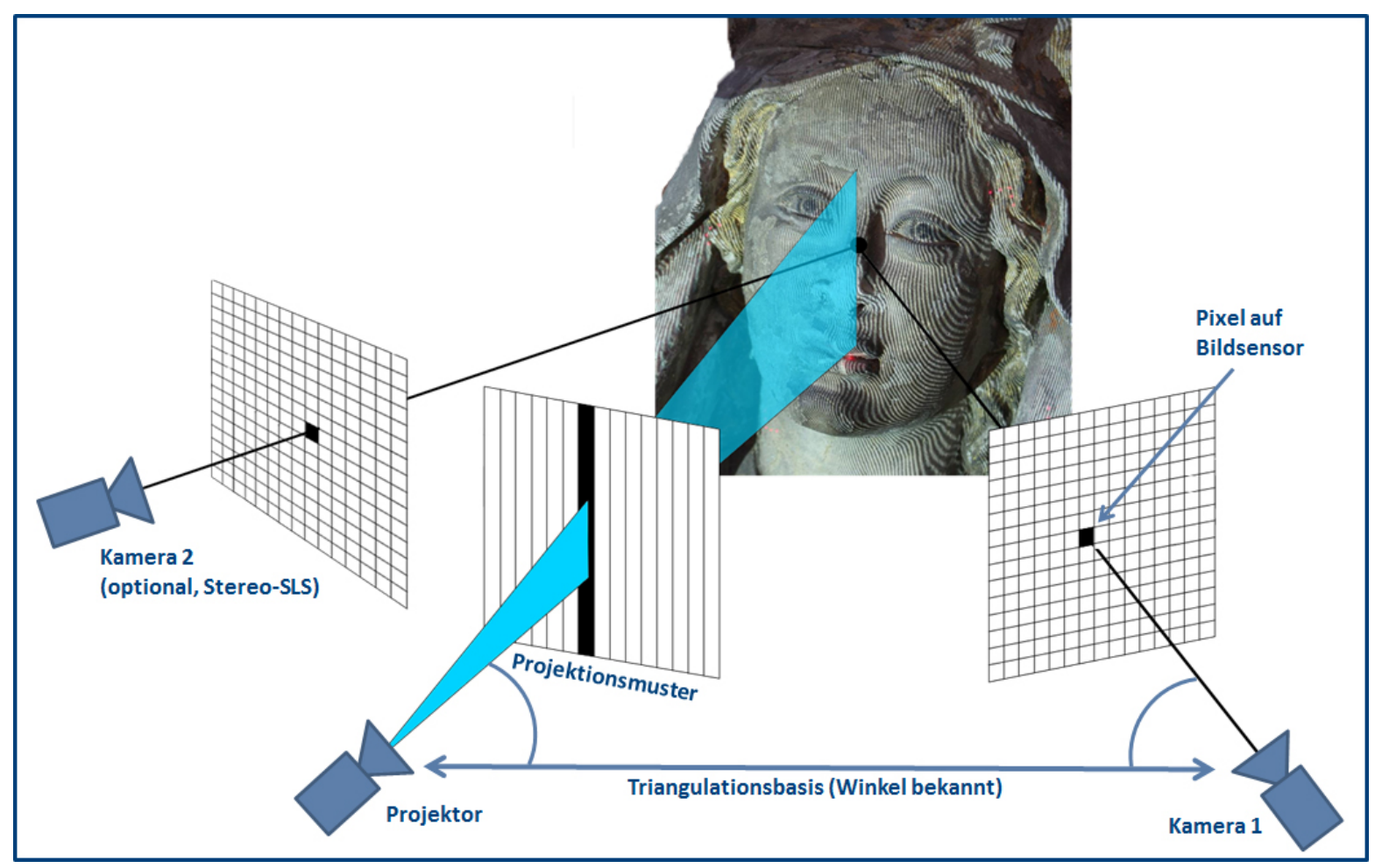

Abb. 07: Funktionsprinzip eines Structured Light Scanners.

Die Messgenauigkeit und der Abstand, mit denen 3D-Punkte gemessen werden können, variieren bei SLS zwischen wenigen Zehntelmillimetern, bis hin zu wenigen Mikrometern. Bei einigen Geräten können hierzu die Objektive von Kamera und Projektor gewechselt werden, bei anderen Varianten wird zudem der Abstand zwischen den beiden Optiken verändert. Bei derzeit aktuellen Geräten liegt die höchste Auflösung bei einem Punktabstand von etwa 12-16 $\mu \mathrm{m}$. Je nach gewünschter Auflösung variiert dabei die Messfeldgröße, bei gleichbleibender Pixelzahl des Bildsensors. Bei hohen Auflösungen hat das Messfeld eine Breite von wenigen Zentimetern, in den gröberen Auflösungen liegt die Breite hingegen bei knapp einem Meter. ${ }^{128}$ Somit kann mit einer einzelnen Messung in der Regel nicht die Oberfläche des gesamten Objekts erfasst werden, weshalb eine Serie von Einzelscans erstellt werden muss (Abb. 08). Die Ausrichtung der einzelnen Aufnahmen zueinander kann durch Passpunkte/Zielmarken oder anhand einer Überlappung zwischen Einzelscans erfolgen. Bei Letzterem wird die Ausrichtung durch einen Vergleich der übereinstimmenden Geometrie mathematisch berechnet. Diese Berechnung wird als ,best-fit' matching oder iterative-closest-point matching (ICP matching) bezeichnet. ${ }^{129}$

\footnotetext{
${ }^{128}$ Vgl. Zeiss Optotechnik 2019, dort Technische Daten des Comet 6 16M und Hexagon 2019, dort Technische Daten des AICON StereoScan neo.

${ }^{129} \mathrm{Vgl.:}$ Kapitel 5.2. 3D-Vergleiche für die Oberflächeninspektion und Qualitätskontrolle im laufenden Restaurierungsprozess, S. 107ff; Gühring 2002, S. 95f; Grussenmeyer et al. 2016, 327f.
} 


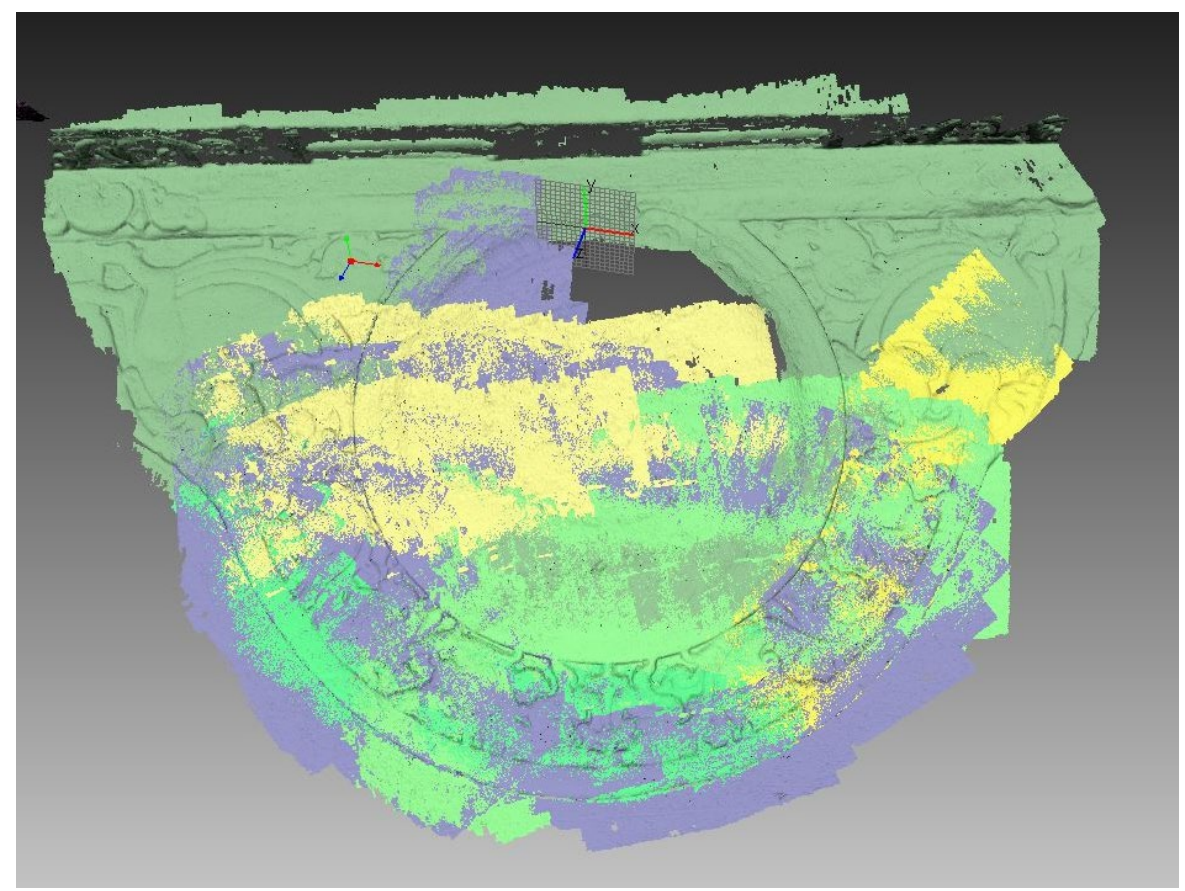

Abb. 08: Kombination mehrerer hochauflösender Einzelscans.

Nachdem ein Objekt Schritt für Schritt mit mehreren Einzelscans erfasst wurde, erfolgt anschließend eine weitere, best-fit'-Ausrichtung aller Scans zueinander, um mögliche Registrierungsfehler auszugleichen bevor die Berechnung eines Oberflächenmodells erfolgen kann. Das resultierende 3DModell stellt eine hochauflösende, geometrisch korrekte Wiedergabe der Oberflächentopografie des Objektes dar (Abb. 09). Hierzu wurden die gemessenen Einzelpunkte zu kleinstmöglichen Flächen, Dreiecken, zusammengefügt. Je nach Hersteller, Software und wissenschaftlicher Fragestellung können anschließend Fehlstellen, die zuvor messtechnisch nicht erfasst werden konnten, interpoliert werden, um ein einheitlich geschlossenes 3D-Modell zu erhalten. ${ }^{130}$

\footnotetext{
${ }^{130}$ Eine ausführliche Erklärung zum Triangulationsprozess für die Erstellung eines 3D-Oberflächenmodells ist zu finden bei Gühring 2002, 107f.
} 


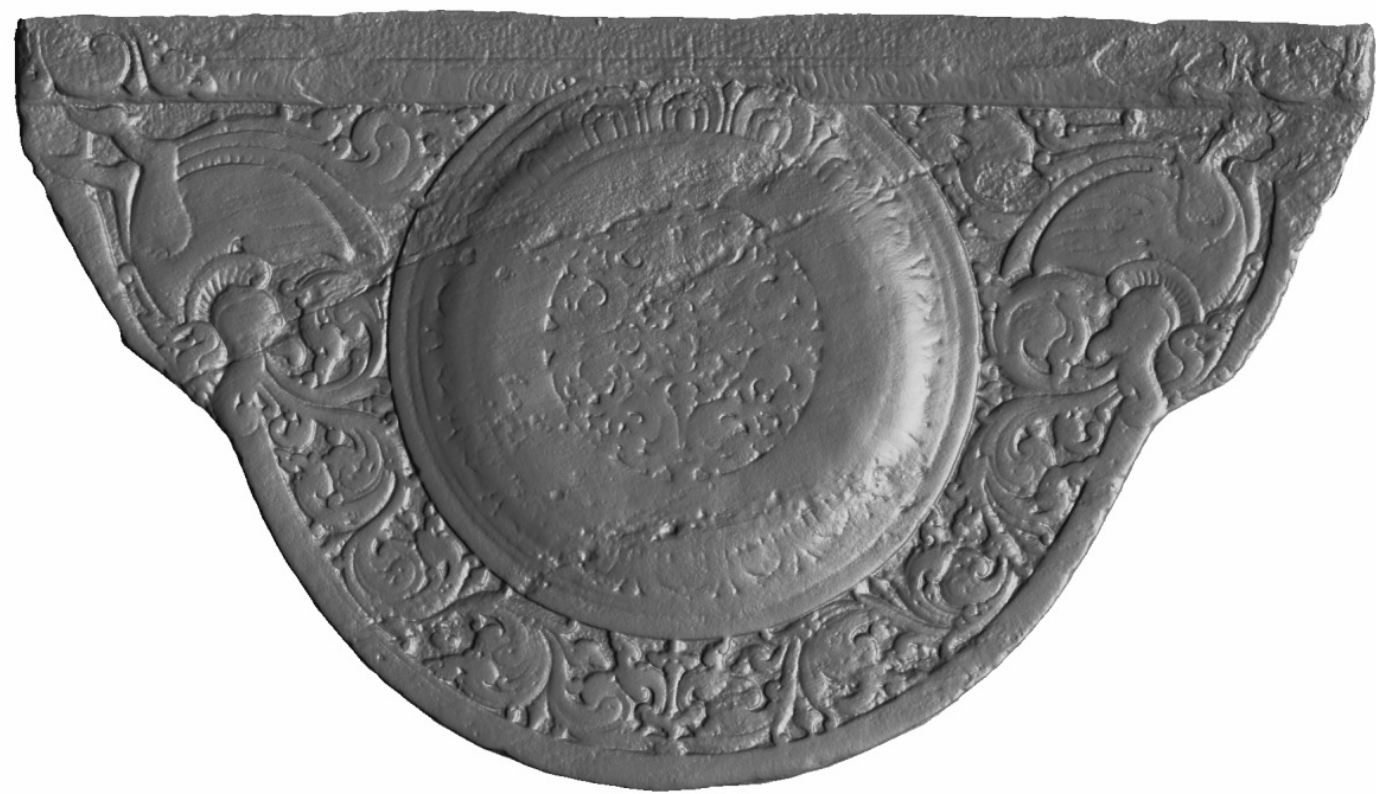

Abb. 09: Finales 3D-Oberflächenmodell eines Sandakada pahana (auch Moonstone genannt) aus dem heiligen Zahntempel in Kandy, Sri Lanka.

An dieser Stelle weist das resultierende 3D-Modell zunächst keinerlei Farbinformationen auf. Bei einigen SLS kann automatisch bei der Erfassung der Oberflächengeometrie mit einer integrierten Kamera die Farbigkeit des Objektes aufgenommen werden. ${ }^{131}$ In diesem Fall wird die Farbinformation anschließend auf das 3D-Modell gerechnet (Abb. 10). Es lassen sich aber auch nachträglich, durch separat erstellte Fotos, Texturen für das 3D-Modell generieren. Der große Vorteil an der separaten Aufnahme von Geometrie und Farbe liegt in der Anpassung der umgebenden Lichtverhältnisse an den jeweiligen Arbeitsschritt. Die Vermessung der Geometrie erfolgt beim SLS idealerweise bei sehr geringem Umgebungslicht. Lichtquellen (egal ob Sonnenschein oder Kunstlicht) können zu Spiegelungen auf der Oberfläche des Objektes führen oder sogar das projizierte Muster des Projektors überstrahlen, so dass die Messungen negativ beeinträchtigt werden oder fehlschlagen. Auf der anderen Seite sollen besonders bei der Dokumentation von Kulturgut farbechte Fotos für die Berechnung der Textur verwendet werden, um ein möglichst authentisches, digitales Abbild zu schaffen. Bei der Aufnahme von separaten Fotos kann dieser Forderungen verhältnismäßig einfach nachgegangen werden, ohne die 3D-Messungen zu behindern. ${ }^{132}$

\footnotetext{
${ }^{131}$ Gühring 2002, S. 82.

${ }^{132}$ Vgl. Kapitel 4.2. Der Bamberger Kaisersaal - Neue Möglichkeiten für eine kunsthistorische Analyse historischer Prunkräume, S. 60ff.
} 

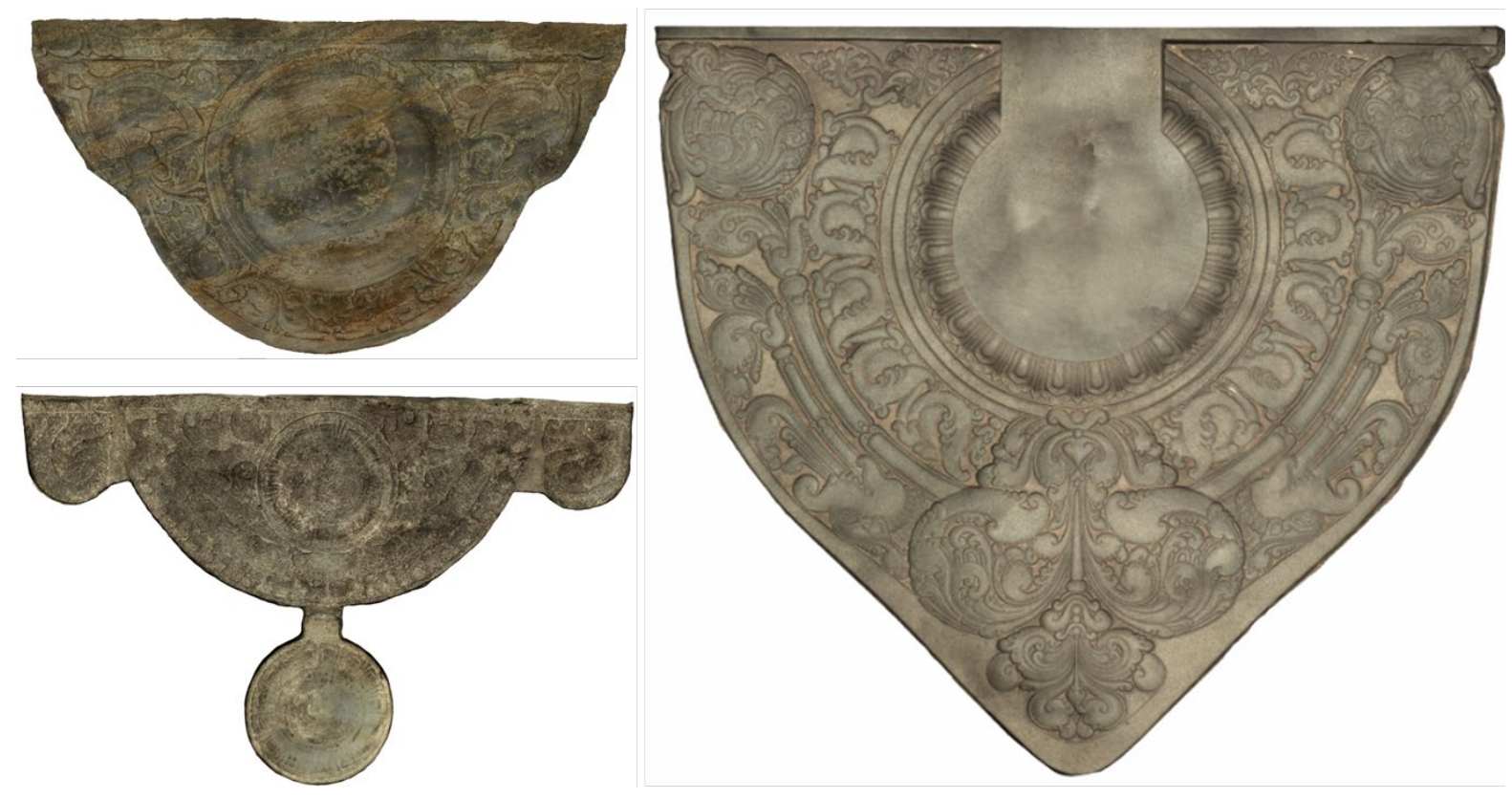

Abb. 10: Fotorealistisch texturierte3D-Modelle von Sandakada pahana / Moonstones aus dem heiligen Zahntempel in Kandy, Sri Lanka.

Structured-Light-Scanner können in der Kulturerbeforschung für viele Anwendungen genutzt werden. ${ }^{133}$ Es beginnt bei der Nutzung des 3D-Modells für eingehende Objektstudien zur Charakterisierung von Oberflächendetails, wie etwa Bearbeitungsspuren, ${ }^{134}$ oder für die Dechiffrierung historischer Inschriften. ${ }^{135}$ Darüber hinaus können geschlossene 3D-Modelle für die Erstellung von Kopien im 3D-Druck- oder CNC-Fräsverfahren verwendet werden. Diese haptischen Kopien können für Ausstellungszwecke genutzt werden, wenn aus verschiedenen Gründen die Präsentation des Originals nicht möglich ist. ${ }^{136}$ Es lassen sich verzeichnungsfreie Ansichten (Orthophotos) für Publikationen und jegliche 2D- und 3D-Kartierungen (wie etwa Befund-, Zustandsund Schadenskartierungen) mit den Daten erstellen. ${ }^{137}$ Zudem lassen sich die 3D-Modelle für den Vergleich von Oberflächen verwenden. Hierzu werden zwei 3D-Modelle, mittels ,best-fit', möglichst

\footnotetext{
133 Bellendorf 2009, S. 201ff.

${ }^{134} \mathrm{Vgl}$. Tenschert 2019a.

${ }^{135} \mathrm{Vgl}$. Tenschert/Rahrig et al. 2019 und Tenschert 2019b.

${ }^{136}$ Der Verfasser war bspw. 2010/2011 an der Erstellung eines 3D-Modells der Madonna/ Muttergottes aus dem Dom zu Meißen beteiligt. Die Figur stammt aus den Jahren um 1260 und wird der Naumburger Dombauwerkstatt zugeordnet. Sie konnte, aufgrund der gut erhaltenen Polychromie und ihrer Verankerung in der rückwertigen Wand, nicht für die Ausstellung „Der Naumburger Meister“ 2011 nach Naumburg transportiert werden. Es wurde daher eine eins-zu-eins Kopie in Stein gefertigt. Vgl.: Homepage der Ausstellung: <https://www.naumburgermeister.de/index.php?id=344> letzter Zugriff 02.08.2019. Ein weiteres Beispiel stellen die 2014 vom Verfasser erstellten Kopien einer keltischen Goldmünze (eines sogenannten Regenbogenschüsselchens) für das Stadtmuseum in Bad Staffelstein dar. Hier können durch die Kopien sowohl die Vorder- wie auch die Rückseite der Münze in der Ausstellung betrachtet werden; das Original wird aus Gründen der Sicherheit nicht im Museum präsentiert. Für nähere Infos: $<$ https://format4plus.de/de/projekte/goldmuenze,-bad-staffelstein/> letzter Zugriff 02.08.2019.

${ }_{137} \mathrm{Vgl}$. Kapitel 5.1. 3D-Vergleiche für kunstwissenschaftliche Serienanalysen, S. 83ff; Kapitel 4.2. Der Bamberger Kaisersaal - Neue Möglichkeiten für eine kunsthistorische Analyse historischer Prunkräume, S. $60 \mathrm{ff}$ und Pfeuffer/Rahrig et al. 2018.
} 
exakt übereinandergelegt. Anschließend erfolgt die Berechnung der Unterschiede zwischen den Datensätzen im Rahmen der Genauigkeit der Modelle. Das Ergebnis wird in einem Fehlfarbenbild dargestellt. Auf diese Weise können Vergleichsstudien von sich ähnelnden Objekten erstellt werden. ${ }^{138}$ Es lassen sich aber auch zwei, zeitlich versetzt, digitalisierte 3D-Modelle vom selben Kulturgut für ein 3D-Monitoring verwenden. So können unter anderem voranschreitende Schadens- und Verformungsprozesse ${ }^{139}$ erfasst und der Zustand eines Kulturgutes vor und nach seiner Restaurierung verglichen werden. ${ }^{140}$

\subsection{Image-Based Modelling / Structure from Motion}

Eine weitere dreidimensionale Messtechnik zur berührungslosen Erfassung von Oberflächen ist das Image-Based Modelling (IBM) oder die Mehrbildphotogrammetrie. Es wird im deutschen Sprachgebrauch häufig als Structure from Motion ( $\mathrm{S} f M$ ) bezeichnet, wobei dies eigentlich nur ein Arbeitsschritt der Prozesskette bezeichnet. Es handelt sich um eine Variante der Photogrammetrie, weshalb auch häufig die Begriffe Photogrammetrie oder Photogrammetry verwendet werden. Anders als bei der Einzelbild- oder Stereophotogrammetrie, bei der einzelne Ebenen entzerrt oder Einzelpunkte stereoskopisch in zwei Fotos gemessen werden, wird bei dieser Messtechnik die dreidimensionale Oberflächengeometrie eines Objektes aus einer Serie von Fotos berechnet. Es handelt sich somit um eine passive Messtechnik, bei der die zu vermessende Oberfläche nicht direkt von dem Vermessungsgerät angeregt wird, ${ }^{141}$ anders als bei den beiden zuvor behandelten Verfahren, bei denen aktiv ein Messsignal ausgesendet wird.

Für die Dokumentation eines Objektes wird zunächst eine Serie an Fotos erstellt. Die Bildausschnitte sollten sich hierbei stets großflächig überlappen, zudem ist auf einen stetigen Wechsel der Kameraposition zu achten. Für verhältnismäßig flache Objekte, z. B. Landschaften, einzelne Fassaden und Wandabschnitte oder Reliefs, ist dabei ein wiederholtes, streifenweises Vorgehen, mit einer wechselnden Kameraneigung empfehlenswert. ${ }^{142}$ Bei plastischen Objekten, wie etwa ganzen Gebäuden, Skulpturen, Baudekor oder archäologischem Fundgut, sollte die Kamera in geschlossenen Kreisen um das Objekt herum bewegt werden (Abb. 11). ${ }^{143}$ Wie die aufgelisteten Anwendungsbeispiele bereits vermuten lassen, liegt der große Vorteil dieser Messtechnik in dem extrem vielseitigen Anwendungsgebiet. Je nach Ausstattung der Kamera kann sie an einem UAV betrieben werden, etwa zur Dokumentation von Landschaften oder Fassaden. UAV steht für unmanned aerial vehicle, hierzu

\footnotetext{
${ }^{138}$ Vgl. Kapitel 5.1. 3D-Vergleiche für kunstwissenschaftliche Serienanalysen, S. 83ff.

${ }^{139}$ Vgl. Kapitel 6. Opto-Technical Monitoring - 3D-Techniken und multispektrale Bildgebung, S. 127.

${ }^{140}$ Vgl. BSV 2018 und Kapitel 5.2. 3D-Vergleiche für die Oberflächeninspektion und Qualitätskontrolle im laufenden Restaurierungsprozess, S. 107ff.

141 Luhmann 2018, S. 24.

142 Murtiyoso/Grussenmeyer 2017, S. 212f.

143 Historic England 2017, S. $34 \mathrm{f}$.
} 
zählen unter anderem Multicopter oder, umgangssprachlich auch, Drohnen. Alternativ kann sie aber auch, mit Makroobjektiven ausgestattet, zur hochauflösenden Digitalisierung von kleinen Objekten genutzt werden. ${ }^{144}$ Die Auflösung und Messgenauigkeit ist dabei von dem Bildmaßstab abhängig, ${ }^{145}$ welcher sich aus dem Aufnahmeabstand, der Brennweite und dem Bildformat (Größe und Auflösung des Sensors) ergibt. Hierbei ist darauf zu achten, dass Spiegelungen und Unschärfe im Bild zu vermeiden sind, da sie zu einer schlechteren Bildqualität und zu Messfehlern im 3D-Modell führen können. ${ }^{146}$ Zur Erstellung eines 3D-Models mittels IBM müssen verschiedene Arbeitsschritte durchgeführt werden. Es beginnt mit der Merkmalserkennung (Feature Detection), der Merkmalszuordnung (Matching) und der Bündeltriangulation (Bundle Adjustment) zur Lageberechnung der Fotos zueinander und zum Objekt. Anschließend folgt das Dense Image Matching (Einzelpunktmessung/Stereomatching) zur Erstellung einer so genannten dichten Punkwolke, welche anschließend in ein 3D-Oberflächenmodell überführt werden kann. ${ }^{147}$

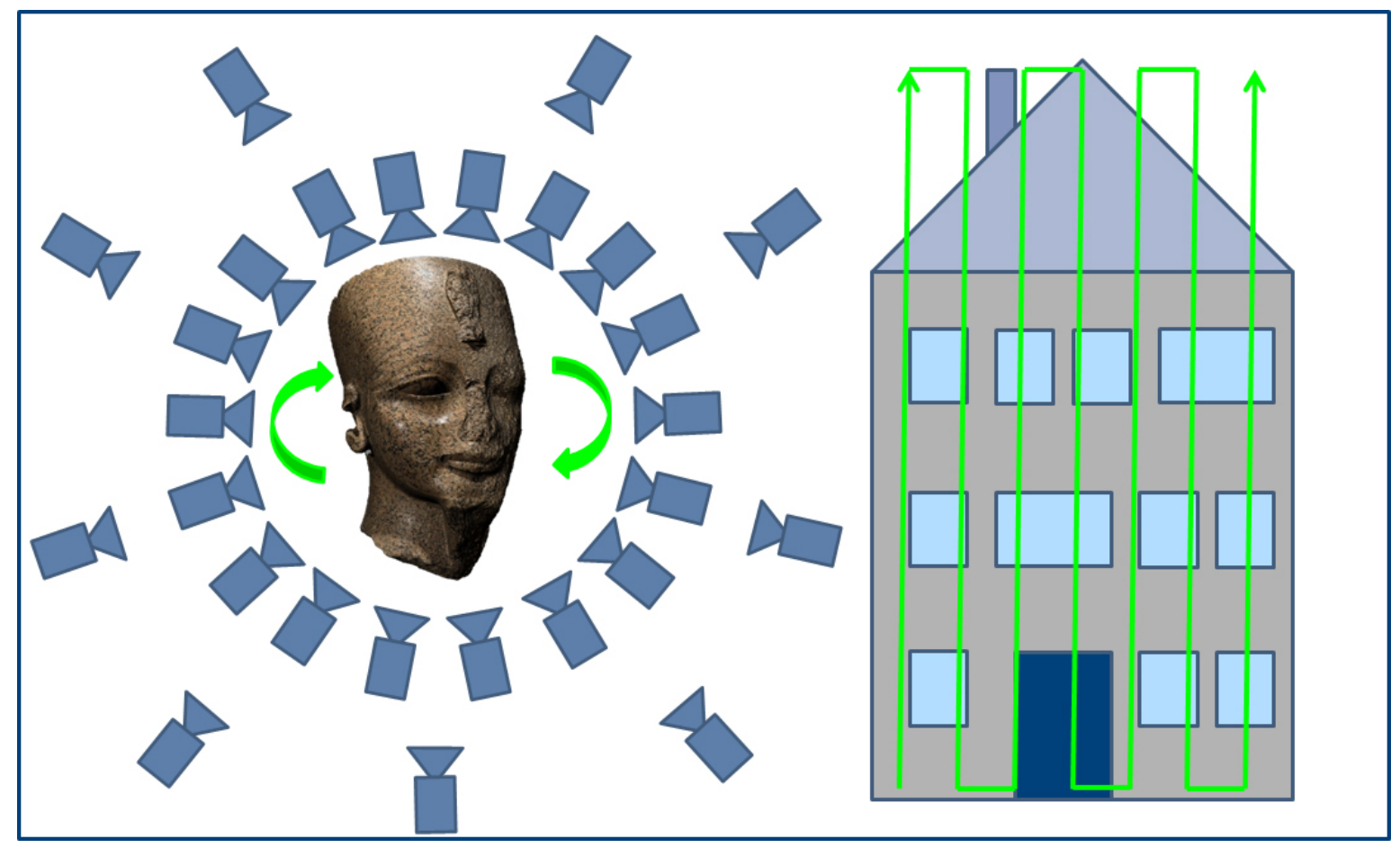

Abb. 11: Schematische Darstellung der Kamerapositionen zur Aufnahme von kleinen und großen Objekten mittels Image-Based Modelling.

Die Merkmalserkennung, -zuordnung und die Bündelausrichtung ${ }^{148}$ erfolgt bei vielen Softwareanwendungen in einem einzelnen Arbeitsschritt. Bei ihrer Berechnung ist zwischen inneren und äußeren Parametern zu unterscheiden. Die äußeren Parameter (äußere Orientierung) beschreiben

\footnotetext{
144 Vgl. Verhoeven/Missinne 2017.

145 Luhmann 2018, S.166f.

146 Ebenda, S. 30.

${ }^{147}$ Ebenda S. 491f, Historic England 2017, S. 4. Für eine ausführliche Beschreibung aller physikalischmathematischer Prozesse der Nahbereichsphotogrammetrie siehe Luhmann 2018.

148 Luhmann 2018, S. 31, S. 340ff, S. $491 \mathrm{f}$.
} 
die Position eines Fotos in Relation zu einem 3D-Koordinatensystem, in dem auch das Objekt bestimmt wird, also die Entfernung, der Neigungswinkel und die Drehung der Kamera zum Zeitpunkt der Aufnahme zum Objekt. ${ }^{149}$ Die Berechnung der äußeren Orientierung sowie der inneren Parameter erfolgt softwaregestützt durch die Erkennung und Verknüpfung von identischen, homologen Punkten (Merkmalserkennung und Merkmalszuordnung). Hierbei kann es sich um gezielt angebrachte Zielmarken (targets oder tie points) aber auch um natürliche Referenzpunkte handeln. Ein homologer Punkt muss dabei in mindestens zwei Fotos erscheinen, damit eine Dreiecksberechnung im Sinne des räumlichen Vorwärtsschnitts, vergleichbar der Punktberechnung beim SLS, erfolgen kann (Abb. 12). ${ }^{150}$ Pro Foto sind mindestens drei Punkte für die relative Lageberechnung innerhalb des Bildverbandes notwendig (räumlicher Rückwärtsschnitt). ${ }^{151}$ Durch die Erfassung von weiteren homologen Punkten erhöht sich die Genauigkeit der Lagebestimmung des Fotos im Bildverband. ${ }^{152}$

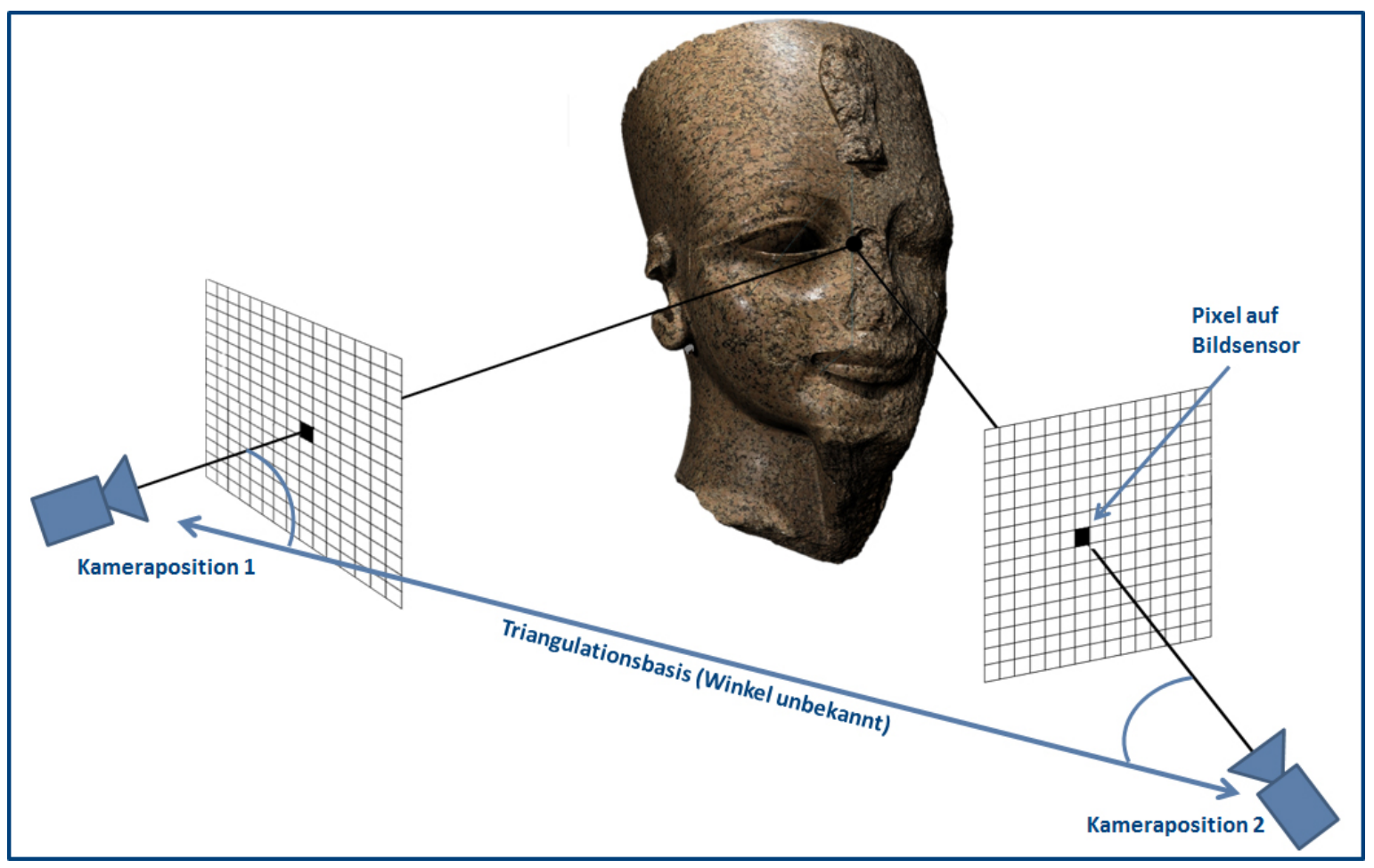

Abb. 12: Schematische Darstellung des räumlichen Vorwärtsschnitts eines homologen Punktes in zwei Kamerapositionen.

Für die Ermittlung der äußeren Parameter müssen zusätzlich die inneren Parameter der Kamera erfasst werden. Diese beschreiben die Bildgeometrie, welche durch die Einstellungen der Kamera und der verwendeten Optik bedingt wird. Denn physisch betrachtet wird die dreidimensionale Welt in einem Foto optisch derart verändert, dass sie perspektivisch verzerrt, in ihrer Größe massiv verändert und

\footnotetext{
149 Historic England 2017, S. $7 f$.

150 Luhmann 2018, S. 29, S. 335f, S. 382ff.

${ }^{151}$ Ebenda, S. 278ff.

152 Stylianidis/Georgopoulos et al. 2016, S. $285 \mathrm{ff}$.
} 
auf eine zweidimensionale Ebene, den Bildsensor, reduziert wiedergegeben wird. Diese Darstellungsform kann als perspektivische Projektion oder Zentralprojektion bezeichnet werden, zu deren Bestimmung die relative Position und Entfernung der Projektionsebene (Bildsensor) zum perspektivischen Zentrum (Objektiv) bekannt sein muss (Abb. 13). Dieses Lageverhältnis wird durch die im Objektiv verbauten Linsen beeinflusst. Bei jeder Veränderung des Zooms und der Fokussierung werden die Linsen zueinander verschoben und ändern somit ihre Position zum Bildsensor. Zudem weichen produktionsbedingt alle Linsen voneinander $a b$, was zu Verzeichnungen führt. Daher ist eine Kalibrierung der Kamera für die Berechnung der inneren Parameter notwendig. ${ }^{153}$ Die Kalibrierung wird mittlerweile softwaregestützt automatisch berechnet, es muss jedoch sichergestellt sein, dass alle verwendeten Fotos bei gleichbleibender Fokussierung und Zoom aufgenommen werden. Darüber hinaus beeinflusst die verwendete Blende die inneren Parameter, da mit ihr die Schärfentiefe des Bildes eingestellt wird. Bei der Aufnahme des Bildverbandes sollte daher auch die Blende konstant, unverändert bleiben. ${ }^{154}$

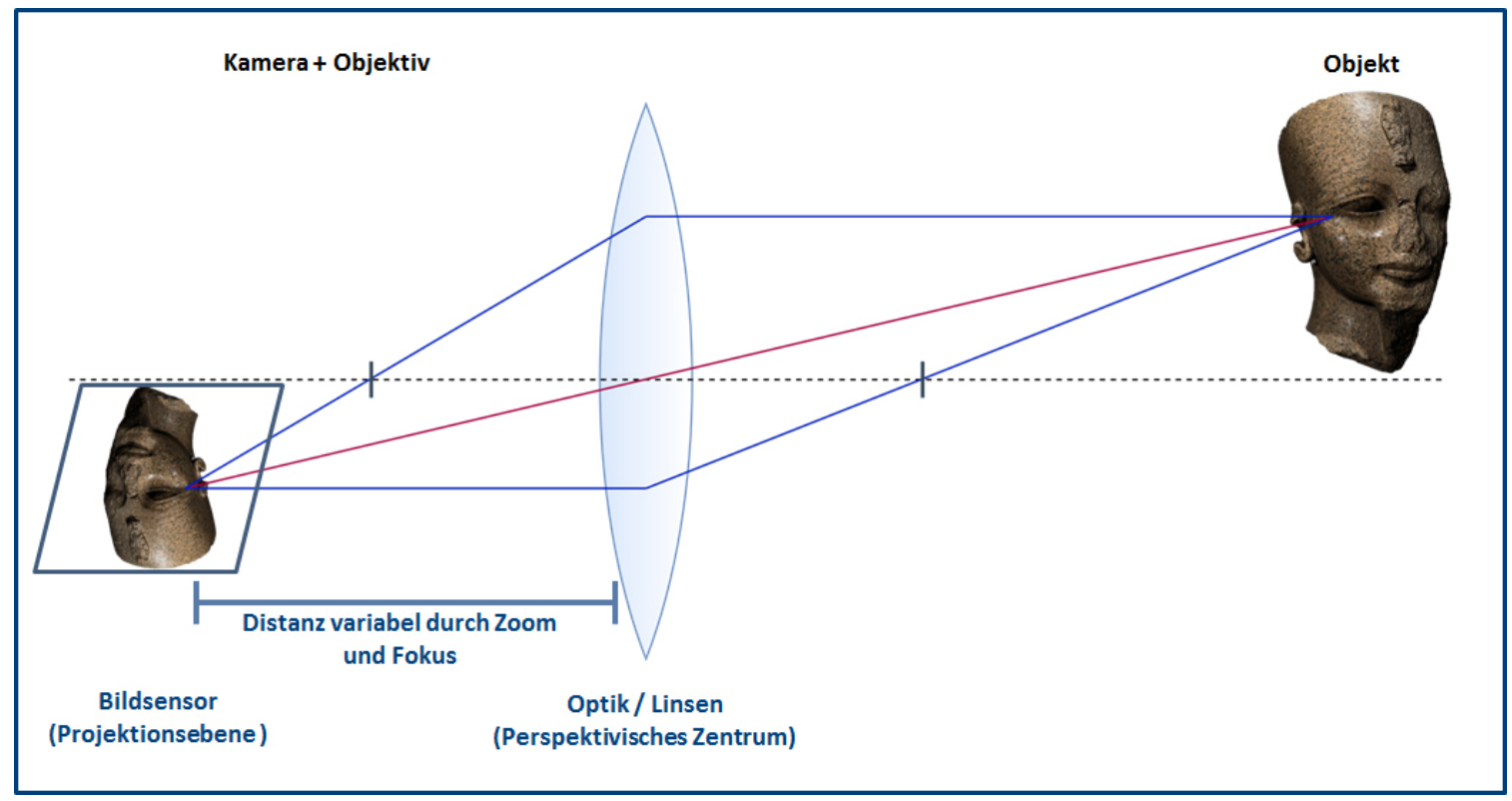

Abb. 13: Vereinfachte Darstellung der inneren Parameter einer Kamera.

Wenn die inneren und äußeren Parameter bestimmt sind, lässt sich anhand der homologen Punkte die relative Lage zwischen der Bildebene, dem perspektivischen Zentrum und dem aufzunehmenden Objekt berechnen. Diese Lagebestimmung beinhaltet jedoch noch keinerlei metrische Informationen zur Größe des aufgenommenen Objektes. Für eine korrekte Skalierung des Datensatzes benötigt es externe Maßangaben. Dies kann durch eine tachymetrische, oder GPS-gestützte, Einmessung von Referenzpunkten oder durch die Platzierung von Maßstäben, Scalebars, mit einer möglichst exakt

\footnotetext{
153 Luhmann 2018, S. 30 und S. $166 \mathrm{ff}$.

154 Stylianidis/Georgopoulos et al. 2016, S. 270 ff; Historic England 2017, S. 20ff; Luhmann 2018, S. $29 f$.
} 
bestimmten Größe, erfolgen. Selbstverständlich müssen die Referenzpunkte und Maßstäbe in den Fotos, oder einem Teil der Fotos, sichtbar sein. ${ }^{155}$

Nachdem der Bildverband zueinander und zum Objekt ausgerichtet wurde, erfolgt in einem nächsten Schritt, dem dense image matching, die Berechnung einer dichten 3D-Punktwolke (Abb. 14). Hierbei wird im Idealfall ein 3D-Punkt aus jedem einzelnen Pixel eines Fotos berechnet. Die Lageberechnung erfolgt hierbei erneut über den räumlichen Vorwärtsschnitt, weshalb ausschließlich 3D-Punkte berechnet werden können, die mindestens in zwei Fotos mit einem Pixel erfasst wurden. ${ }^{156}$ Auf diese Weise entsteht eine möglichst flächendeckende 3D-Punktwolke des Objektes, welche anschließend analog zu den Arbeitsschritten bei TLS und SLS für verschiedene Anwendungen genutzt werden kann. Wird die Punktwolke in ein 3D-Oberflächenmodell überführt, können die Fotos aus dem Bildverband anschließend für die Berechnung eines hochauflösenden Texture Mappings genutzt werden. Der große Vorteil liegt hierbei in der bereits bekannten Ausrichtung der Fotos zum Objekt aufgrund der Bündelausgleichung. ${ }^{157}$

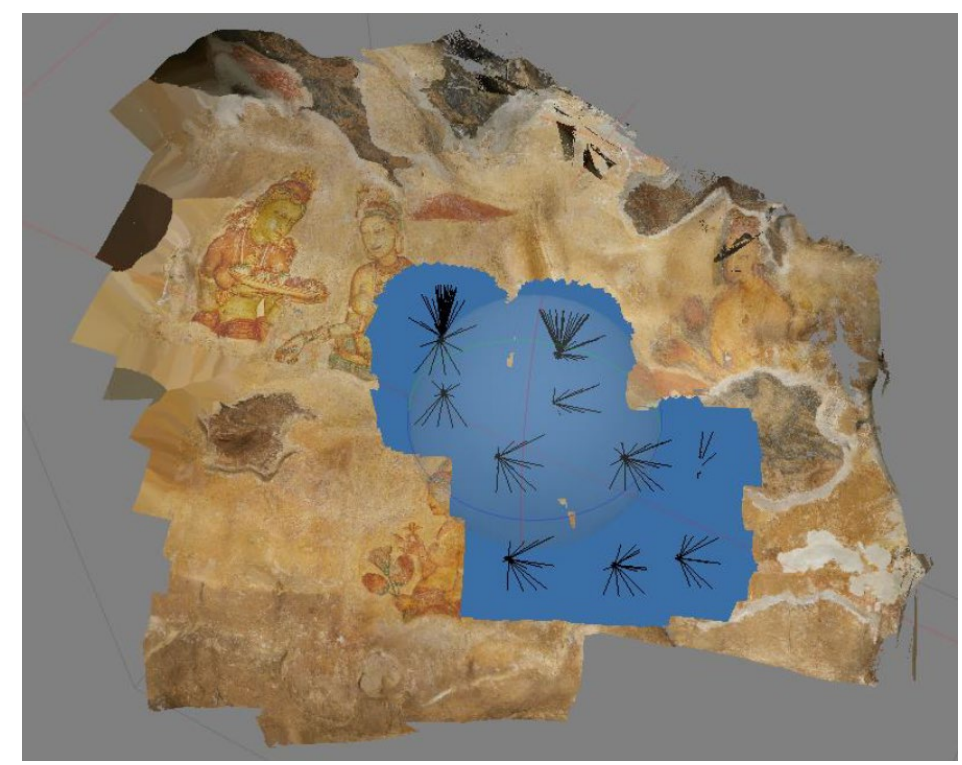

Abb. 14: Darstellung einer dichten Punktwolke und den dazugehörigen Kamerapositionen in blau.

Bei der Verwendung des gleichen Koordinatensystems kann die Texturberechnung zudem auf Oberflächenmodelle des TLS oder SLS angewendet werden. In diesem Fall genügt es, den Bildverband sowie die Skalierung und die Ausrichtung zu berechnen und anschließend das externe 3DOberflächenmodell zu importieren. ${ }^{158}$

\footnotetext{
155 Stylianidis/Georgopoulos et al. 2016, S. 290; Historic England 2017, S. $53 \mathrm{ff}$.

156 Stylianidis/Georgopoulos et al. 2016, S. 290 ff; Historic England 2017, S. $14 f$ und 77f.

${ }^{157}$ Vgl. Kapitel 4.2. Der Bamberger Kaisersaal - Neue Möglichkeiten für eine kunsthistorische Analyse historischer Prunkräume, S. 60ff.

158 Ebenda.
} 
Wie oben beschrieben, erfolgt die Ableitung der Koordinaten eines 3D-Punktes beim Image-Based Modelling durch die Berechnung des räumlichen Vorwärtsschnitts zwischen mindestens zwei Fotos und dem Zielpunkt. Sie ist also vergleichbar mit dem Rechenprozess zur Ermittlung von 3D-Punkten beim Structured-Light-Scanning. Im Unterschied zum SLS müssen beim IBM jedoch wesentlich mehr Variablen beachtet werden, auf die der ausführende Operator aktiv einwirken kann. Die inneren und äußeren Parameter lassen sich bei gängigen SLS häufig nur nach Vorgabe im Rahmen der Änderung des Messfeldes verändern, etwa durch den Wechsel der Objektive. Anschließend erfolgt dann eine Kalibrierung nach strikten Vorgaben des Herstellers, um die geforderte Messgenauigkeit zu gewährleisten. Durch die unmittelbare Registrierung der Einzelscans während der Datenaufnahme kann das 3D-Modell zudem direkt auf seine Vollständigkeit kontrolliert werden. Beim Image-Based Modelling muss die Person, die die Fotos erstellt, zwingend mit der notwendigen Sorgfalt auf die Einhaltung gleichbleibender Parameter achten ${ }^{159}$ und benötigt, analog zur Bedienung eines SLS, ausreichend Erfahrung, um abschätzen zu können, ob alle zu dokumentierenden Bereiche ausreichend erfasst wurden. Nur so kann die gewünschte Genauigkeit und eine für das Denkmal oder Kulturgut angemessene Dokumentation gewährleistet werden.

\subsection{Multispektrale Bildgebung}

Bei der multispektralen Bildgebung handelt es sich um ein weites Feld der optischen Messtechnik. Hierbei werden verschiedene Wellenlängen elektromagnetischer Strahlung genutzt, um eine bildliche Wiedergabe eines Objektes zu generieren. Das Spektrum der Wellenlängen, die vom menschlichen Auge als sichtbares Licht wahrgenommen werden können, stellen dabei nur einen ganz kleinen Bereich der für die multispektrale Bildgebung nutzbaren Wellenlängen dar. In Abbildung 15 ist ein Überblick des elektromagnetischen Spektrums dargestellt. Er beginnt bei sehr kurzen und damit hochfrequenten und energiereichen Wellenlängen, wie der Gamma- und Röntgenstrahlung, und endet bei langwelligen, energiearmen Strahlungen, den Mikro- und Radiowellen. Dazwischen finden sich die ultravioletten (UV), sichtbaren (VIS) und infraroten (IR) Lichtspektren. ${ }^{160}$ Das in Kapitel sechs behandelte Opto-Technical Monitoring beschränkt sich auf bildgebende Verfahren zur Inspektion von Oberflächen unter der Nutzung von Licht in den Spektralbereichen zwischen UV-A/Nahbereichs-UV, beginnend bei etwa $320 \mathrm{~nm}$, bis hin zu Licht der Wellenlänge des NIR/Nahbereichs-IR, bis etwa $1100 \mathrm{~nm} .{ }^{161}$ Bildgebende Verfahren wie Röntgen oder die Mittelwellen IR-Reflektografie sowie die Thermografie zählen ebenfalls zu dem breiten Feld der spektralen Bildgebung. Ihre Möglichkeiten des

\footnotetext{
159 Remondino 2013, S. 121.

${ }^{160}$ Vgl. Verhoeven 2012, S. 3ff.

${ }^{161} \mathrm{Vgl}$. Kapitel 6. Opto-Technical Monitoring - 3D-Techniken und multispektrale Bildgebung, S. $127 \mathrm{ff}$.
} 
Einsatzes innerhalb der Kulturerbeforschung stellen jedoch ganz eigene Forschungsfelder dar, die hier nicht umfassend behandelt werden können.

Der behandelte Spektralbereich von etwa 320 bis $1100 \mathrm{~nm}$ lässt sich mit dem Bildsensor einer handelsüblichen Digitalkamera erfassen. Hierzu muss allerdings der IR-Sperrfilter entfernt werden, welcher vor dem Bildsensor platziert ist und normalerweise das IR-Spektrum herausfiltert. Anschließend erreichen die elektromagnetischen Strahlen ungefiltert den Bildsensor. Um dann gezielt das eintreffende Licht auf eine bestimmte Wellenlänge zu reduzieren, benötigt es spezielle Filter, die vor dem Objektiv der Kamera platziert werden. ${ }^{162}$

\section{Electromagnetic spectrum}

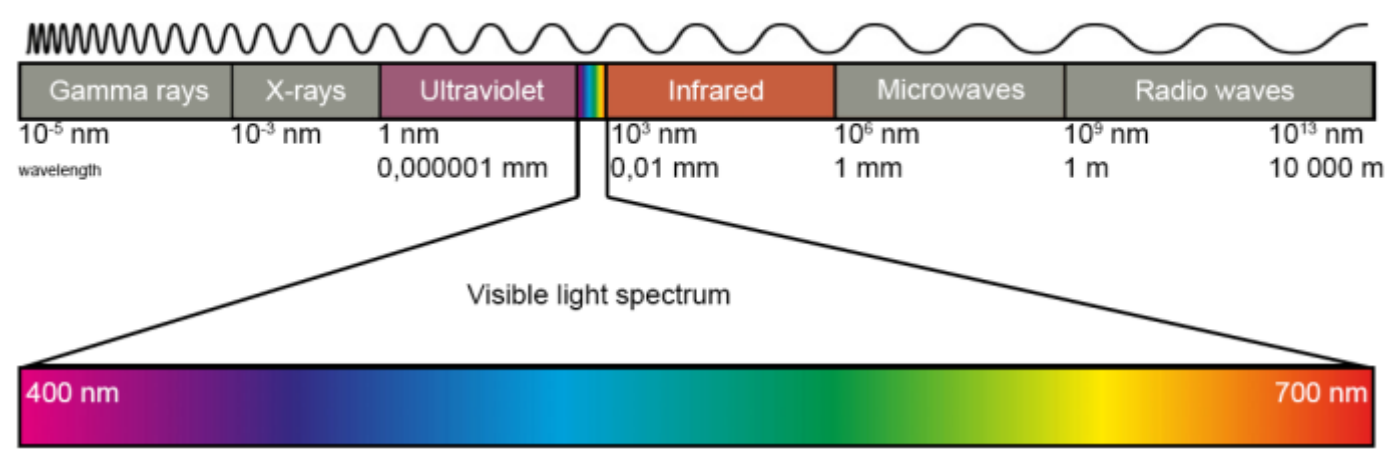

Abb. 15: Übersicht über das elektromagnetische Spektrum

Die hier angewendete UV-VIS-IR-Fotografie bedient sich dem Umstand, dass unterschiedliche Materialien charakteristisch auf verschiedene Wellenlängen des Lichts reagieren. ${ }^{163}$ Wird ein Objekt elektromagnetischen Wellen ausgesetzt, etwa mit einer Glühbirne bestrahlt, kann die Oberfläche auf verschiedene Arten reagieren. Das Material kann auf die Wellenlänge transluzent wirken. In diesem Falle können die elektromagnetischen Wellen durch das Material hindurch wandern. Dies kennt man zum Beispiel vom Röntgen, aber auch von Fensterscheiben. Die elektromagnetische Strahlung kann zudem absorbiert, das heißt von dem Material vollständig aufgenommen oder reflektiert, und somit wie bei einem Spiegel zurückgestrahlt werden. Die Reflexion erfolgt dabei in der gleichen Wellenlänge wie die Anregung. Ferner können einige Materialien fluoreszierend auf die Anregung mit elektromagnetischer Strahlung bestimmter Wellenlängen reagieren. Hierbei wird ein Teil der Strahlung absorbiert und elektromagnetische Strahlung in einer abgeschwächten Wellenlänge emittiert. Das passiert besonders bei bestimmten Pigmenten, aber auch lebenden Organismen, die während der Anregung mit UV-Licht im sichtbaren Spektralbereich bunt leuchten. ${ }^{164}$

\footnotetext{
162 Cosentino 2014, S.2; Verhoeven 2012, S. 14ff; Dyer et al. 2013, S. 44; Webb et al. 2018, S. $1184 f$.

163 Cosentino 2014, S.1; Webb et al. 2018, S. 1183.

164 Dyer et al. 2013, S. 2ff, Cosentino 2015, S. 58.
} 
Kontrolliert man nun die ausgehenden Wellenlängen der Lichtquelle und erfasst dessen Reflexionen bzw. Emission in einem bewusst gewählten Spektrum, lassen sich charakteristische Merkmale einzelner Materialien erkennen. Dies kann als berührungslose und zerstörungsfreie Untersuchungsmethode in der Kulturerbeforschung genutzt werden, wodurch sich unter anderem verwendete Pigmente in einer Malerei bestimmen lassen können. ${ }^{165}$ Bei der UV-VIS-IR-Fotografie sind mit verschiedenen Filtern und speziellen Lichtquellen dabei folgende Kombinationen von induziertem, also ausgesendetem und erfasstem, reflektierten Spektralbereich möglich (Abb. 16): ${ }^{166}$

- UVR: UV-induzierte UV-Reflektografie: Die Anregung erfolgt ausschließlich mit UV-Strahlen (200-400 nm) und es wird die Reflexion im ultravioletten Spektralbereich erfasst. ${ }^{167}$

- UVF oder UVL: UV-induzierte VIS-Reflektografie; auch bekannt als UV-Fluoreszenzfotografie: Die Anregung erfolgt mit UV-Strahlung (200-400 nm) und es wird das Reflexionsverhalten im visuellen Spektrum (400-700 nm) erfasst. ${ }^{168}$

- UV-induzierte IR-Reflektografie: Die Anregung erfolgt mit UV-Strahlung (200-400 nm) und es wird das Reflexionsverhalten im infraroten Spektrum (700-1100 nm) erfasst. (Möglich, wird jedoch in der Kulturerbeforschung nicht angewendet.)

- UV-VIS-induzierte VIS-Reflektografie: Die Anregung erfolgt mit UV-VIS-Strahlung (200-700 nm) und es wird das Reflexionsverhalten im visuellen Spektrum (400-700 nm) erfasst. (Möglich, wird jedoch in der Kulturerbeforschung nicht angewendet.)

- UV-VIS-induzierte IR-Reflektografie: Die Anregung erfolgt mit UV-VIS-Strahlung (200-700 nm) und es wird das Reflexionsverhalten im infraroten Spektrum (700-1100 nm) erfasst. (Möglich, wird jedoch in der Kulturerbeforschung nicht angewendet.)

- UV-VIS-IR-induzierte IR-Reflektografie: Die Anregung erfolgt mit UV-VIS-IR-Strahlung (200$1100 \mathrm{~nm}$ ) und es wird das Reflexionsverhalten im infraroten Spektrum (700-1100 nm) erfasst. (Eine Variante der IRR, bei der eine undefinierte Lichtquelle, wie etwa ein Halogenstrahler oder Baustrahler ohne UV-Filter, für die IR-Anregung genutzt wird.)

- VIS: VIS-induzierte VIS-Reflektografie, besser bekannt als normale Farbfotografie: Die Anregung erfolgt mit VIS-Strahlung (400-700 nm); es wird das Reflexionsverhalten im visuellen Spektrum erfasst. ${ }^{169}$

\footnotetext{
165 Cosentino 2014, S.1f; Dyer et al. 2013; Webb et al. 2018, S. 1184.

166 Neben den aufgeführten Varianten der multispektralen Bildgebung werden im Bereich der Wandmalereiuntersuchung auch sogenannte Falschfarben-Fotos erstellt, bei denen die Bildkanäle des VIS mit Bildkanälen anderer Wellenlängen gemischt werden. Siehe hierzu Lang/Lenz 2017.

${ }^{167}$ Dyer et al. 2013, S. 4; Cosentino 2014, S. 2.

${ }^{168}$ Dyer et al. 2013, S. 5; Cosentino 2014, S. 2.

${ }^{169}$ Dyer et al. 2013, S. 3; Cosentino 2014, S. 2.
} 
- IRF oder VIL: VIS-induzierte IR-Reflektografie, auch als IR-Fluroreszenz bezeichnet: Die Anregung erfolgt mit VIS-Strahlung $(400-700 \mathrm{~nm})$ es wird das Reflexionsverhalten im infraroten Spektrum $(700-1100 \mathrm{~nm})$ erfasst. ${ }^{170}$

- VIS-IR-induzierte IR-Reflektografie: Die Anregung erfolgt mit VIS-IR-Strahlung (400-1100 nm) und es wird das Reflexionsverhalten im infraroten Spektrum (700-1100 nm) erfasst. (Eine Variante der IRR, bei der eine undefinierte Lichtquelle, wie etwa ein Halogenstrahler, ein Baustrahler oder eine Blitzanlage mit UV-Filter, für die IR-Anregung genutzt wird.)

- IRR: IR-induzierte IR-Reflektografie; auch bekannt als reine IR-Reflektografie: Die Anregung erfolgt mit IR-Strahlung (700-1100 nm); es wird das Reflexionsverhalten im infraroten Spektrum erfasst. ${ }^{171}$

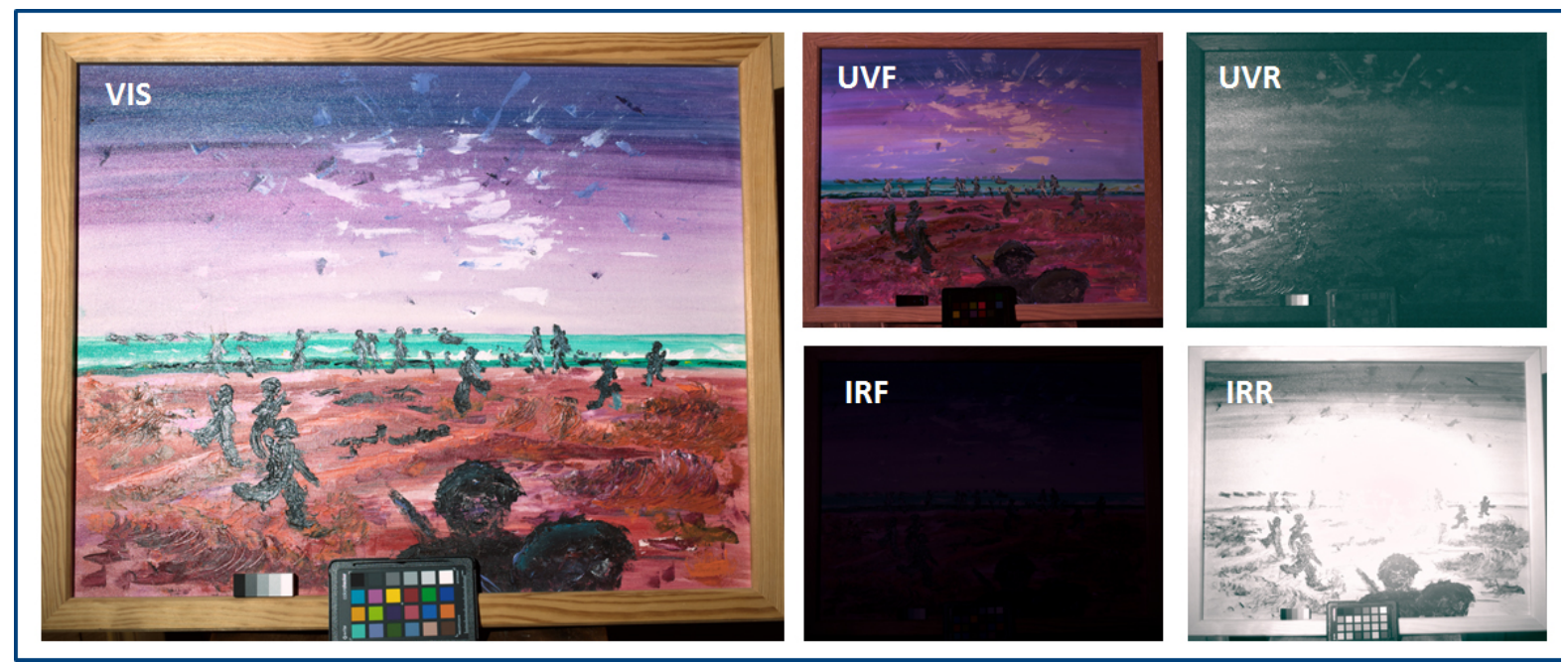

Abb. 16: Modernes Ölgemälde auf Holzfaserplatte, als Beispiel der multispektralen Bildgebung.

Die gängigsten genutzten Methoden sind dabei die UV-Fluoreszenz (UVF), die VIS-Fotografie (VIS) sowie die IR-Reflektografie (IRR). ${ }^{172}$ Im Rahmen des Opto-Technical Monitoring zur Erfassung von Konservierungsmaterialien auf Steinoberflächen innerhalb des EU-Forschungsprojektes NanoCathedral wurden aus Gründen der Praktikabilität, der erwarteten Ergebnisse und zur Optimierung der Arbeitsschritte lediglich diese drei Methoden angewendet. Ausführliche Informationen zu dem verwendeten technischen Setup, der Aufbereitung der Fotos und den Möglichkeiten und Grenzen der Aufnahmetechniken sind Kapitel 6, ,Opto-Technical Monitoring - 3D-Techniken und multispektrale Bildgebung', zu entnehmen. ${ }^{173}$

\footnotetext{
170 Dyer et al. 2013, S. 5; Cosentino 2014, S. 2.

${ }^{171}$ Dyer et al. 2013, S. 4; Cosentino 2014, S. 2.

172 Dorell 1994, S. 198ff.

173 Siehe S. $127 \mathrm{ff}$.
} 


\section{3D-Erfassung komplexer Großobjekte}

Der Einsatz von bildgebenden, zerstörungsfreien Prüf- und Dokumentationsmethoden bietet herausragende und vielseitige Möglichkeiten zur denkmalgerechten Erfassung von Be- und Zuständen von Kunst- und Kulturgütern, insbesondere auch von komplexen Großobjekten. Bei der Verwendung klassischer Dokumentations- und Messtechniken, wie etwa des Handaufmaßes oder der Tachymetergestützten Vermessung, erfolgt die Arbeit gezielt zur Beantwortung einer konkreten Fragestellung. Es werden dabei ausschließlich die Punkte angemessen, welche in dem Moment für die jeweiligen Problemstellungen relevant sind. Abhängig von der grundlegenden Kernfrage und Fachdisziplin werden dabei ganz unterschiedliche Darstellungsarten benötigt. So bedarf die konstruktionstechnische Analyse eines Bauwerkdetails ggf. einer schematisierenden und interpretierenden Darstellung des Objektes. Für eine Schadenskartierung hingegen soll die Plangrundlage möglichst den exakten, interpretationsfreien Zustand zum Zeitpunkt der Dokumentation darstellen. In beiden Fällen wird vor der Dokumentation festgelegt, wo eine Schnittoder Ansichtsachse zur Erstellung eines Plans verlaufen soll und welcher Darstellungsmaßstab angestrebt wird. Nach erfolgreicher Arbeit existiert in der Regel nur dieser Datensatz. Bedarf es nachträglich eines Versatzes der Schnittachse oder Ansichtsebene, da sich neue Fragestellungen ergeben haben, muss eine vollständig neue Vermessung durchgeführt werden.

Durch eine hochauflösende, dreidimensionale Vermessung, wie etwa unter der Verwendung von TLS, wird hingegen eine flexible Arbeitsgrundlage für verschiedene Fachdisziplinen in der Kulturerbeforschung geschaffen. Der besondere Vorteil liegt dabei in der flächendeckenden und vor allem in der interpretationsfreien Abtastung der Oberflächen. Durch das so gewonnene digitale Derivat, welches als eigenständiges Zeitdokument des Kulturerbes zu betrachten ist, ${ }^{174}$ können anschließend bautechnische, kunstwissenschaftliche, restauratorische oder auch museologische Forschungsansätze gezielt bearbeitet werden. Die Durchführung der Dokumentation und Auswertung der Daten sollte dabei stets von Akteur*innen durchgeführt werden, die sowohl im Umgang mit der Technik wie auch mit der Arbeit an historischen Objekten vertraut sind. Eine fehlerfreie Erfassung und Interpretation der Daten können dabei nur mit hinreichendem Wissen über das Objekt und seine Materialität erfolgen. Selbstverständlich wird die TLS-gestützte Dokumentation zunächst für die Beantwortung der initialisierenden und auftraggebenden Fragestellungen ausgewertet. Demnach werden auch hier die oben beschriebenen Pläne generiert, welche als zweites, interpretierendes Zeitdokument zu betrachten sind. Entwickeln sich nachträglich jedoch weitere Fragen, können diese, aufgrund der interpretationsfreien Dokumentation, unmittelbar mit den vorliegenden Daten bearbeitet werden. Hierbei bedarf es dann ggf. nur einiger weniger ergänzender Messungen.

\footnotetext{
${ }^{174}$ Vgl. Kapitel 7. Dokumentation und Archivierung, S. $145 \mathrm{ff}$.
} 
Voraussetzung hierfür ist die umfassende Dokumentation und Archivierung der erhobenen Daten (Roh-, Ergebnisdaten und Grund der Maßnahme). ${ }^{175}$ Die Vorgehensweise der TLS-gestützten Dokumentation, unter der Berücksichtigung der ethischen Leitsätze, führt somit langfristig zu einer ressourcenschonenden Optimierung des Aufwandes, wodurch Zeit und Kosten gespart werden können. Nachfolgend soll dies an zwei Beispielen eingehend dargelegt werden.

\subsection{Der Zahntempel - Kulturerbeforschung und Wissenstransfer}

Die Dokumentation des heiligen Zahntempels, Sri Dalada Maligawa, in Kandy, Sri Lanka, erfolgte in den Jahren zwischen 2015 und 2017. Das Projekt wurde mit finanziellen Mitteln aus dem KulturerhaltProgramm des Auswärtigen Amtes gefördert. ${ }^{176}$ Zusätzliche Unterstützung erfolgte durch die deutsche Botschaft in Colombo. Ziel des Projektes war die Erstellung einer umfassenden, dreidimensionalen Dokumentation der bedeutendsten buddhistischen Tempelanlage Sri Lankas. Die Daten wurden anschließend für die Erstellung von CAD-Bestandsplänen sowie für die Generierung von 3DVisualisierungen des Gebäudekomplexes für die Medienabteilung des Tempels verwendet. Im Sinne des Wissenstransfers wurden die Arbeiten unter Einbeziehung sri-lankischer Fachkräfte durchgeführt, die im denkmalgerechten Umgang mit moderner Messtechnik geschult wurden. Darüber hinaus stellen die erhobenen Daten die erste umfassende, denkmalgerechte Dokumentation der Welterbestätte des heiligen Zahntempels dar, welche der zuständigen Tempeladministration vorliegt. Langfristig sollen die erhobenen Messdaten für ein Verformungs-Monitoring der Hauptfassade verwendet werden. Aufgrund eines Bombenattentats im Jahr 1998, bei dem der Haupteingang zerstört wurde, war eine Schwächung der Fundamente und des aufgehenden Mauerwerks der Hauptfassade zu verzeichnen.

Das Projekt erfolgte unter der Leitung von Prof. Dr. Rainer Drewello und war in den Restaurierungswissenschaften der Otto-Friedrich-Universität Bamberg angesiedelt. Die Projektkoordination oblag dem Verfasser, die CAD-Pläne wurden von Anna Luib M.A. erstellt. Weitere beteiligte Institutionen waren das Special Projects and Media Bureau des Sri Dalada Maligawa, sowie die kleinen und mittelständischen Unternehmen (KMUs) Format4plus GmbH, Format4asia Ltd. und Infosurv Lanka Ltd.

\footnotetext{
${ }^{175}$ Vgl. Kapitel 7. Dokumentation und Archivierung, S. 145ff..

${ }^{176}$ Förderkennzeichen: FKZ 2515AA0702
} 
Publikation 1: Sri Dalada Maligawa - 3D-Scanning and Documentation of the Temple of the Sacred Tooth Relic at Kandy, Sri Lanka (Rahrig/Luib 2017)

Der Artikel ist hier als Post-Print in einem angepassten Layout wiedergegeben. Für eine korrekte Zitierweise und Seitenzahlen bitte die Originalquelle verwenden:

Rahrig M. / Luib A.: „Sri Dalada Maligawa - 3D-Scanning and Documentation of the Temple of the Sacred Tooth Relic at Kandy, Sri Lanka." In: ISPRS Ann. Photogramm. Remote Sens. Spatial Inf. Sci., IV2/W2, 2017, S. 229-236, Doi: https://doi.org/10.5194/isprs-annals-IV-2-W2-229-2017.

(Double blind peer reviewed Journal)

\section{Abstract:}

Sri Dalada Maligawa - the Temple of the Sacred Tooth Relic - is one of the most important pilgrim sites in Buddhist culture. It is the main part of the UNESCO World Heritage Site Sacred City of Kandy. Since the end of the $17^{\text {th }}$ century the temple has been keeping the sacred tooth of the Buddha. Until now an accurate documentation of the temple with all its rich decorations is missing. The Temple is built in an area vulnerable to environmental factors like earthquakes or monsoon rains and was the target of terrorist attacks. To help preserving this important cultural heritage a research project was carried out. Main part of the project was a 3D-documentation of the entire temple by using Terrestrial-LaserScanning (TLS) and the creating of CAD-Plans. In addition to the documentation of the architecture several details were taken in high resolution by Structured-Light-Scanning (SLS). All data will be part of the digital archive of the temple and were used as a base for a general site monitoring, especially to observe cracks. Next to the mere documentation a transfer of knowledge was another aim of the project. In future most of the analysis of the scan data can be done by local specialists.

\section{The Site}

Sri Dalada Maligawa (Fig. 1), the Temple of the Sacred Tooth Relic, is one of the most important pilgrim sites in Buddhist culture. The temple and its surrounding buildings form the Chorus of the UNESCO World Heritage Site Sacred City of Kandy in the central highlands of Sri Lanka. On the north side of the Kandy Lake next to the city centre of Kandy there is an area which concentrates on Buddhist and Hinduist temples, shrines and stupas. The British colonialists also built up a catholic church, St. Paul's, next to the temple site. On the east end of the area the former King's Palace with the Temple of the Sacred Tooth Relic is situated on top of a terrace 4 meters above the surrounding area. At the end of the $17^{\text {th }}$ century when the Sinhalese kings ruled their country from Kandy city again, they built up a temple to store the most important Buddhist Relic of Sri Lanka: the sacred tooth of the Buddha. This relic was also a symbol of the royal power (De Silva, 1985). 


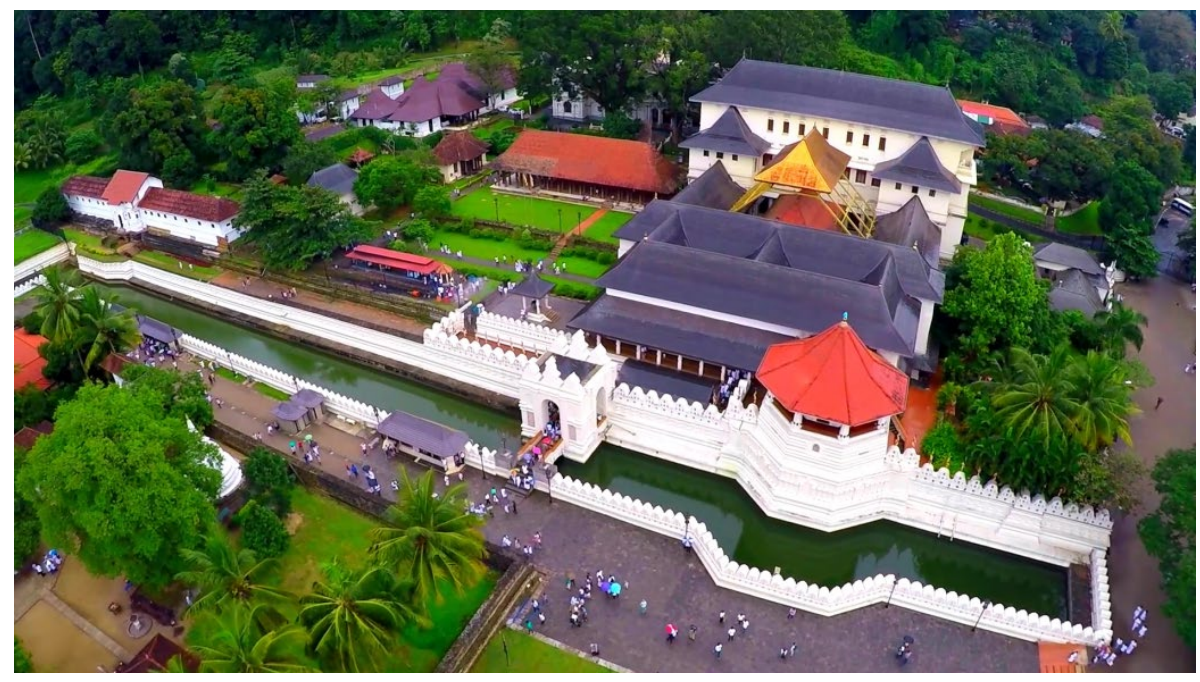

Fig. 1. The temple complex at Kandy

During the centuries several structural changes on the area took place: Today the ancient royal buildings like King's Palace, Queen's Palace, Audience Hall and Royal Bathing Place are grouped in a wide, open park around the temple buildings (Fig. 1). These are part of a grown structure with ancient buildings from the $17^{\text {th }} / 18^{\text {th }}$ century like the Pattirippuwa/Octagonal tower now containing an important library of historical Buddhist Sanskrit scripts. Besides there are younger parts like the new shrine room and museum from 1936 at the east end of the complex. In the centre of the site there is an open courtyard where the sanctum, a two-storied shrine preserving the Sacred Tooth Relic, is located and now additionally covered with a gilded modern roof (De Silva, 1994).

All over the temple area there are rich and filigree decorations in different materials like wall paintings, well carved woods, ornamented stones and gilded surfaces. The Audience Hall from the $17^{\text {th }} / 18^{\text {th }}$ century for example is preserved as an open hall founded on a profiled bed stone. The roof is based on a construction with 64 wooden pillars. Each pillar and most of the horizontal beams are decorated with complex carved floral ornaments. In front of each entrance to the temple and to most of the adjacent buildings moonstones are situated (De Silva, 1985).

Moonstones are traditional doorsteps with a central meaning in the Buddhist culture. During the period of the Kandyan Kingdom they are mostly triangle shaped stones with a round lotus in the centre surrounded by floral ranks (Seneviratna, 1987). The lotus allegorizes the nirvana surrounded by material desires and lusts. By stepping over a moonstone into the temple the believer will lose all material desires and lusts analog to the passage into the nirvana. At Sri Dalada Maligawa more than 15 ancient moonstones are preserved (IBM, 2015).

The shrine itself is the most and richest decorated part of the whole site. It is situated on a profiled bed stone in the centre of the temples courtyard. There are wall paintings on each side of the shrine showing ornaments as well as figures and special animals. The ground floor is surrounded by a veranda. 
Stone pillars decorated with carvings and paintings carry a wooden canopy. It is richly painted and very colourful, the ceiling beams frame picture fields telling the story how the Sacred Tooth reaches Sri Lanka and becomes a royal insignia (De Silva, 1985). The main side of the Shrine facing the west to the drum beating corridor contains a portal with silver covered doors and a coloured stone door frame (Fig. 2). The drum beating corridor itself guides the visitors directly to the shrine after entering the temple building through the main entrance.

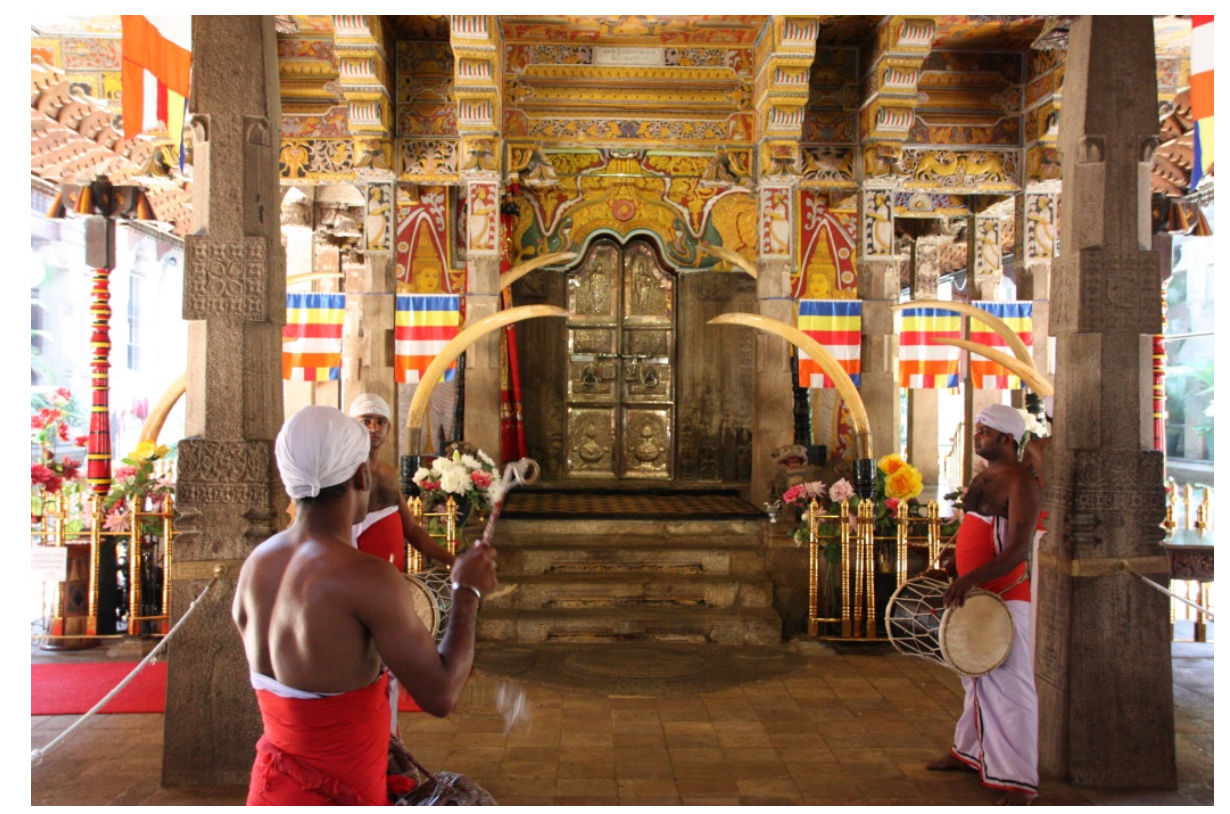

Fig. 2. Drum beating corridor and main side of the shrine

\section{Heritage at Risk}

Because of its meaning as the most important Buddhist site in Sri Lanka several thousand pilgrims from all over the world visit the Sri Dalada Maligawa each day to pray or to sacrifice in front of the sacred tooth. It is also one of the most popular tourist magnets of the island. Every guided bus tour through the country has to include a sight-seeing tour in Kandy. Furthermore, individual tourists and back packers usually make an intermediate stop during their travels through the central highlands and tea plantations.

This very high number of visitors means an enormous burden and stress for the historical structures. Continuous passing over, pushing and sliding along the historical surfaces causes damages and loss by deterioration.

Because of its religious, cultural and touristic importance the temple was a main target of terrorist attacks for several times, most recently in January 1998, when the Tamil Tigers (LTTE) blew up the main entrance. During the attack 17 visitors lost their lives and the historical buildings took enormous damage because of the explosion and the corresponding vibrations. The detonation was extremely powerful and the surrounding temples and shrines in the western area were also affected. Even 150 
m away, at St. Paul's Church, the historic stained glass windows were damaged. The detonation destroyed the whole entrance with its ancient elephant reliefs and a famous ancient moonstone. In addition the foundations and upper walls at the main façade of Sri Dalada Maligawa were thoroughly damaged, especially the Pattirippuwa/octagonal tower (Coningham/ Lewer, 1999).

During the reconstruction work most of the building structures were repaired, but there has been no site monitoring or static assessment since the work was finished. Until today there are many deep and complex cracks visible in the masonry. Considering its location in an area vulnerable to environmental and climatic factors like earthquakes or monsoon rains in combination with the existing structural damages after the attack the Sri Dalada Maligawa is a heritage at risk!

Until nowadays repairing, modifications and structural strengthening of damaged parts is mainly focusing on the religious and spiritual usability of the buildings or objects. For a fast recovering in their use for rituals and customs normally it leads to replacement and reconstruction. The irretrievable loss of the material heritage, resulting from that processes, is a problem which is realised by the responsible very slowly. So there is a lack of experience in handling the rising heritage consciousness and they really need support about the practical and conceptual care and maintenance of their cultural heritage. This is highly important to preserve and save the world heritage site for future generations.

\section{Project Requirements}

Since the terror attack particularly the local community, but also the general public, has been worried about their holy place. Nonetheless, a site monitoring or a general documentation of the status quo was missing until the project started. The temples administration did not have any architectural drawings which are absolutely indispensable as a basis for ongoing and future construction works or for the design of a new visitor guidance system or even an emergency escape route map.

The Special Project and Media Bureau of the temple is operating on a high technical level disposing of 35 employees and support for special projects. They had their own podcast video channel and realize live shows, documentations, interviews and reports all by their own.

In collaboration with the Media Bureau and three SMEs from Sri Lanka and Germany a research project for a first documentation of the temple was carried out in October 2015, founded by the Cultural Preservation Programme of the German Federal Foreign Office. The project duration was agreed to be about one year starting with six weeks of fieldwork. This limited time period was filled with a lot of measures and corresponding activities. The entire temple complex with all of its buildings and numerous details had to be documented in 3D and in a high resolution. The projects aim was to use the data for generating CAD-drawings, a basis for site monitoring of damaged areas as well as 3Danimations and other visualisations (Gonizzi Barsanti et al., 2013) for facility management and 
emergency escape route maps. Therefore, it was necessary for the documentation to be done using Terrestrial-Laser-Scanning (TLS) on the overall area and Structured-Light-Scanning (SLS) for details.

Another major requirement was the possibility to have locals trained in processing and analysing the data and in heritage preservation to give a fast support to the temple administration. Due to the short project duration it was impossible to process all data and generate all required CAD-drawings. For a completion of the work later a transfer of knowledge is useful too. The Sri Lankan colleagues were trained in all relevant processes and in handling of the - to them - new 3D-technologies. In future most of the analysis and processing of the scan data can be carried out by these local specialists.

\section{Fieldwork}

The scanning campaign was done within six weeks in November and December 2015. During this time all work was carried out by a team of four to five people, two Sri Lankan and two or three German specialists. The fieldwork was divided into four steps: First of all a measuring of fixed control points was required, followed by the Terrestrial-Laser-Scanning of the whole site, afterwards StructuredLight-Scanning of important details was executed and in the end an introduction into the postprocessing of the data was given to the Sri Lankan colleagues.

\subsection{Measuring of control points}

As a basic surveying for orientation and registration of the scan data several fixed control points spread over the temple area were marked at the ground and measured with a total station (Wiedemann, 2004). The georeferencing of the measurements is attempted, but no GPS GNSS rover was available, but existing measuring points located by the local surveying office were used. Here, in particular, fixed points in the street between Media Department, Temple and World Buddhist Museum. In the future these points can be used to co-register additional scans with the collected data. For the site monitoring the fixed points can be used for the correct orientation of new scans from already measured areas. The coordinates provided by the surveying office were not available during the project duration, so the measurements were made in a local reference system. As soon as the necessary data have been transmitted, the georeferencing can be made up.

\subsection{Documentation of the building complex}

A complete documentation of all buildings and the surrounding park was intended. Because of the short time span available and the tremendous and extensive requirements on the documentation the scanning device had to be chosen carefully (Grussenmeyer et al., 2016). The use of an often successfully used Faro Focus 3D was discussed especially because of its low weight, small packing size and its easy handling. This device is currently often used for a fast documentation of building complexes. But it is impossible to register or to check the completeness of single scans directly in the 
workflow on site without losing much time. Its use during visitor traffic was impossible due to the covering of important parts and tie points by tourists.

Alternatively it could have been possible to generate a Digital-Surface-Model (DSM) of the temple site using Image-Based Modelling Techniques in combination with a unmanned aerial vehicle (UAV) (Stylianidis et al., 2016). This could provide a fast and good basis for developing visitor guide maps and emergency escape route maps. However a complete documentation of all areas including the inner building parts in a resolution up to $3 \mathrm{~mm}$ exceeded the limits of this technique. In addition, data collection had to be carried out during full visitor traffic. With a few thousand visitors per day a featurebased 3D reconstruction is impossible because of too many movements and deviations in the photo series.

A Riegl VZ 400 (Fig. 3) was chosen because of the difficult determining factors of the project. One of the great advantages of this device is that it can be used in a standalone mode without any external hardware; however, in this case the registration of the single scans must be processed later in the office. Experience has shown that the separation of the measuring and registering of multiple scan positions is not very efficient, because the workflow can be very abstract and difficult to understand for untrained or inexperienced people. That is one reason why the scanner is used in combination with a laptop and the software RiSCAN PRO for controlling the device on site. There are additional advantages in using this workflow: The single scans can be checked for completeness and accuracy directly in the field. As the measurements had to be done during daytime at regular visitor traffic, you always have to check if all important areas are measured or if a re-measurement is necessary because visitors covered some parts. Another advantage is that the correct capturing of reflector marks, which are used to register scan positions and the standard deviation of registered scans can also be checked directly. A maximum deviation for all scans of about approximately $3 \mathrm{~mm}$ is guaranteed.

At each scan position usually two single scans were recorded: first of all a $360^{\circ}$ overview in a resolution between 5 to $15 \mathrm{~mm}$ and a detailed scan of the important areas like façades in a resolution up to 1 to $3 \mathrm{~mm}$ (Fig. 4). Additionally to the documentation of the geometries colour information was recorded for each scan position. Therefore, a Nikon D700 with $14 \mathrm{~mm}$ lens connected to the top of the scanner was used. To achieve a constant colour quality single pictures are captured in manual mode. Quality control and completeness of the pictures were also checked immediately. A much better texture quality is guaranteed by using an external medium format camera with high quality lenses instead of a camera integrated in a scanning device. 


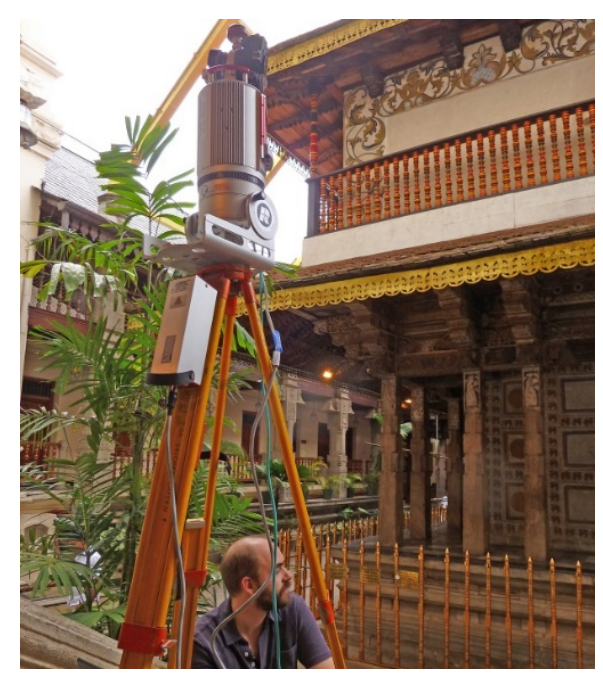

Fig. 3. 3D-Scanning at the shrine with RiegI VZ 400

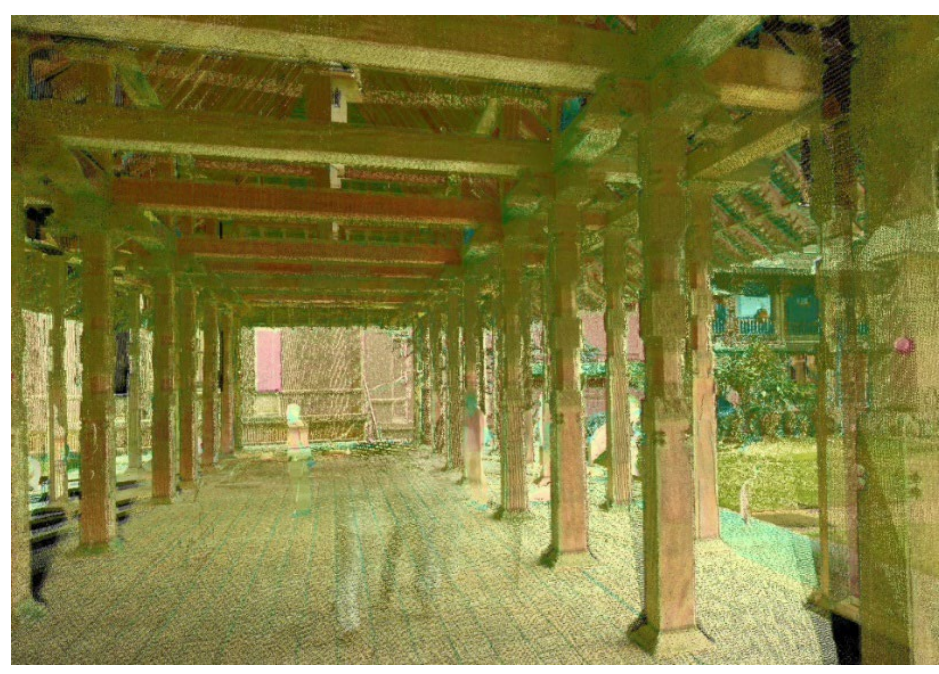

Fig. 4. Point cloud showing the Audience Hall. Combination of reflectance and true colour information

The measurements were executed in teams of about 4 to 5 persons. At first glance it might look overstaffed but regarding the great importance of the temple in the mind of the local community there was not only a great interest but also worries about the visitors of the temple. Most of the time three colleagues were continuously busy with public relations work. The reactions of the visitors reached from scepticism, fear about the temple up to curiosity and interest in the ongoing documentation. The use of a laptop in the field was also very successful. It was possible to show the perhaps confusing work to the visitors and to explain the work carried out. In the end all visitors who asked about information were convinced and their minds put ease about the work done in the project. There were also many visitors who on top of asking the team doing the measurements went to the Media Office for further information. The requests were so numerous that a live interview at the temples podcast channel was recorded to inform about the project in general and about the harmlessness of the completely nondestructive and contactless work.

During the measuring campaign 189 scan positions were recorded and most of the temple area was scanned. Only some parts like the central areas in front of the shrine and the monks` quarters could not be measured yet because of religious concerns. Even the monks were sceptical and bit worried about the modern technologies like the visitors and tourists. After presenting the first project results during the post-processing all concerns could be laid down. In a following project the missing areas could get measured. 


\subsection{Documentation of details}

Some surfaces are very richly decorated and documentation in a much higher resolution was necessary. The techniques which could be used for this work were also affected by the projects conditions. Important requirements are (decreasing in weight):

- easy handling also during visitor traffic

- different light conditions like outdoor and sunlight to diffuse illuminated areas in the inner building parts

- controlling of quality and completeness on site

- fast data capturing and processing

- highest resolution possible

- texture information

Image-Based Modelling Techniques were excluded because of the missing possibility for a fast controlling of the completeness, quality, process ability and accuracy on site. The necessary processing time for these purposes would have been too long considering the short time span for the measuring campaign.

High quality SLS like the Aicon/Breuckmann SmartScan or the Zeiss/Steinbichler COMET deliver best results in accuracy and resolution (Bellendorf, 2011). But these techniques have comparatively big sensor heads and periphery devices like the controlling unit requiring more space surround the scanning area which is difficult to use during visitor traffic. It is further possible that visitors could trip over the many cables needed.

All requirements are served by the handheld structured-light-scanner Artec MHT (Fig. 5). The device allows documentation in a resolution up to $0.5 \mathrm{~mm}$ which preserves a really high level of detail. Texture information is captured automatically during scanning. With 15 scans per second the single scans can be matched automatically by a best fit algorithm due to its huge overlapping. To scan an object the device has to be moved in a flowing motion at a distance of about 0.4 to $1.0 \mathrm{~m}$ to the surface which is to be recorded. The scanning process can get checked for completeness directly on site with the controlling laptop. All together the workflow is very intuitive and easy to learn, whereby the instruction of the Sri Lankan colleagues and regular recording of the objects during visitor traffic passed without problems (Fig. 5). In total 11 historical moonstones spread across the whole temple area and parts of the woodcarvings at the Audience Hall were scanned and are ready to be filed in an archive. 


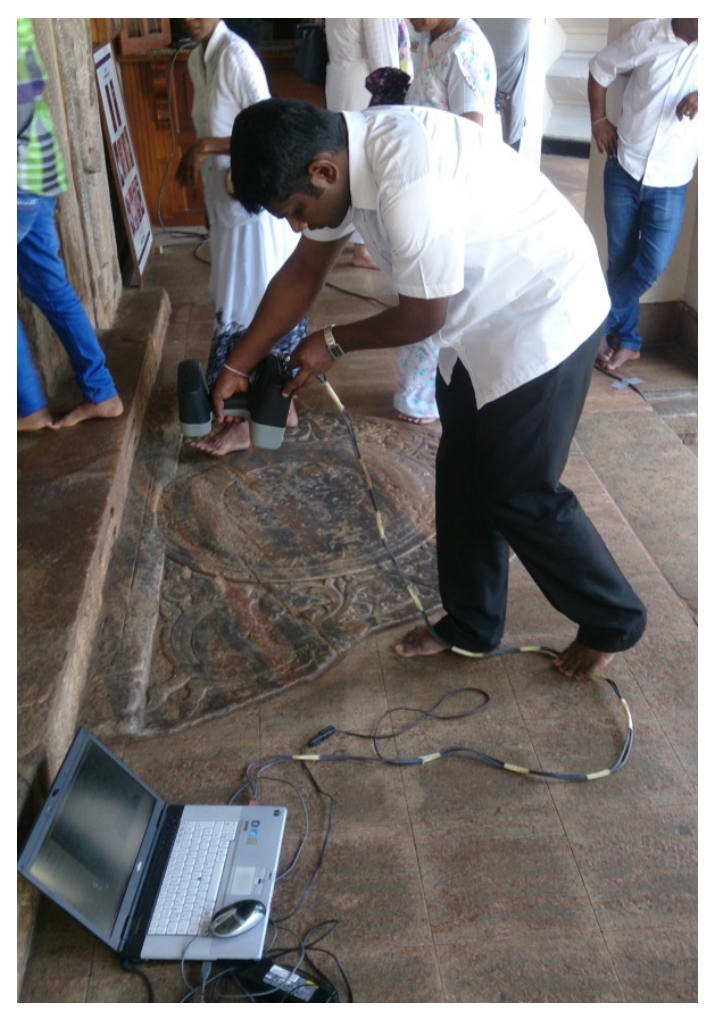

Fig. 5. Documentation of the moonstone at the entrance to the inner temple with Artec MHT

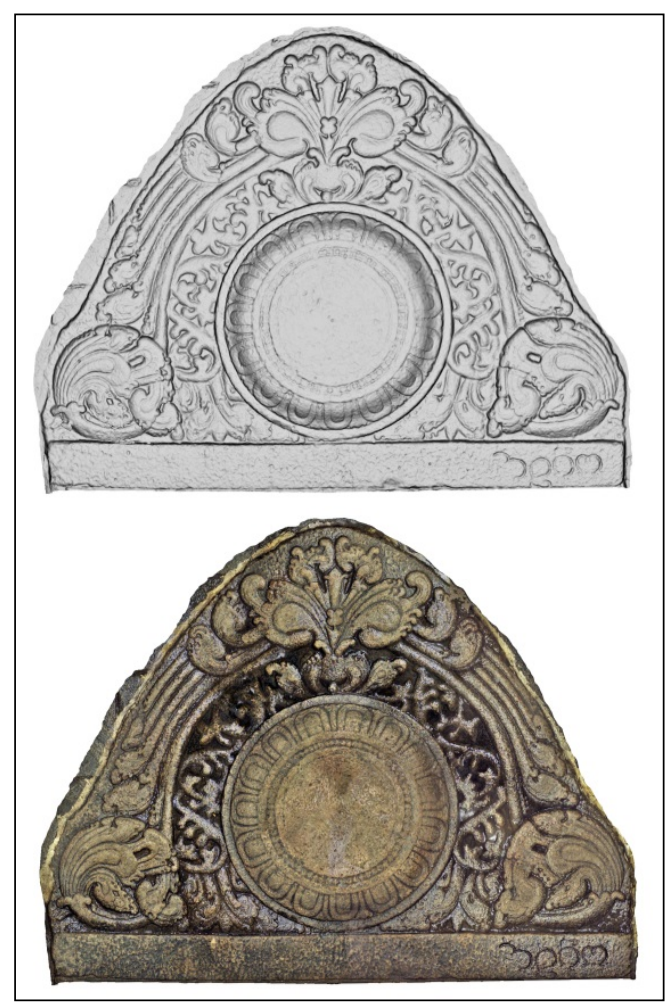

Fig. 6. Moonstone. Shaded relief and textured 3D-Model

\section{Post-Processing}

\subsection{High resolution 3D-Models of details}

Structured-light-scans were processed to high resolution textured 3D-surface models. After checking the completeness and deleting insufficient scans the batch of single scans was registered and triangulated with the scanning software Artec Studio. In a next step the surface model was exported to Geomagic Studio for further optimizations like reducing of noise and spikes, filling of holes and adjustment of edges and borders. Afterwards the cleaned models were reimported to Artec Studio and became texturized. At the end of the workflow the resulting model was orientated to simplify further processing and exported as *.OBJ-file.

There were two variations of 3D-models processed: One model with highest resolution in the geometry and a second model with reduced geometrical information. Both are connected to colour information by texture mapping. Thus, there is no reduction in quality or resolution of the texture information even for the reduced model.

The high-resolution-model (Fig. 6) contains all details like cracks, roughness of the surface and delicateness of the ornaments given straight from the geometry. The texture provides additional information about natural grain, colour of the stone, potential paintings and gloss. 
The reduced models contain the same texture information but less geometrical details. Because of less detail their data size is much smaller and can easily be used by the Special Projects and Media Bureau for animations and web presentations.

Next to the use for temple purposes the digital models can also be used for example by art historians or archaeologists at Kelaniya University and by the Sri Lankan Department of Archaeology for further research on the moonstones in Kandyan style.

\subsection{As-built drawings}

One of the core aims of the use of the TLS-data is generating as-built drawings in CAD. During the project duration it was possible to draw the first three sample plans: a ground floor plan of the entire temple area with park, audience hall and adjoining buildings (Fig. 8), an elevation of the main façade (Fig. 7) and a cross section through the drum beating corridor with view to the main side of the shrine.

For processing the drawings all single scans were first of all matched best-fit with RiSCAN PRO to reduce possible registration errors. Afterwards the scans were separated into bundles and merged to connected point clouds. The separation of the point cloud was done by using building parts like the audience hall, the park, the drum beating corridor or the octagon. AutoCAD was not able to handle one point cloud of the entire scanned area in high resolution so the separation into bundles was necessary to ensure a smooth workflow.

The point clouds of the single bundles were imported to AutoCAD and were processed with the Addon Pointsense Heritage from Faro/Kubit. The drawing was done by using 3D-points. The resolution allows drawings in the level of Detail III and IV by Eckstein (1999) which includes as built drawings in an accuracy up to $0.5 \mathrm{~cm}$ with relevant information about deformation of the structures usable for complicated restorations and construction works.

Drawing the plans ensures a high level of care and experience in point cloud handling (Riedel et al., 2011). The project conditions do not allow later re-measurements of covered areas and there are no useable plan sets existing for controlling or as basis for drawing. The output fulfils the required standards and accuracy. All deformations and wall thicknesses are drawn in good quality and correct scale. The ground floor plan of the whole temple site (Fig. 8) covers an area of more than $160 \times 100 \mathrm{~m}$. The plan is drawn in a scale of 1 to 50. A printout would need a paper size of $3.2 \times 2.2 \mathrm{~m}$ ! During the short project duration there were three plans drawn in quality and scope like this.

Next to the mere documentation of the architectural ensemble there were many other requirements to the drawings in focus of the Special Projects and Media Bureau and the temple administration. The drawings should build a basis for developing emergency escape route maps and visitor guide maps. All 
data were processed in a way that the additional drawings and the remaining works could be done by the Media Bureau and the Sri Lankan project partners independently.

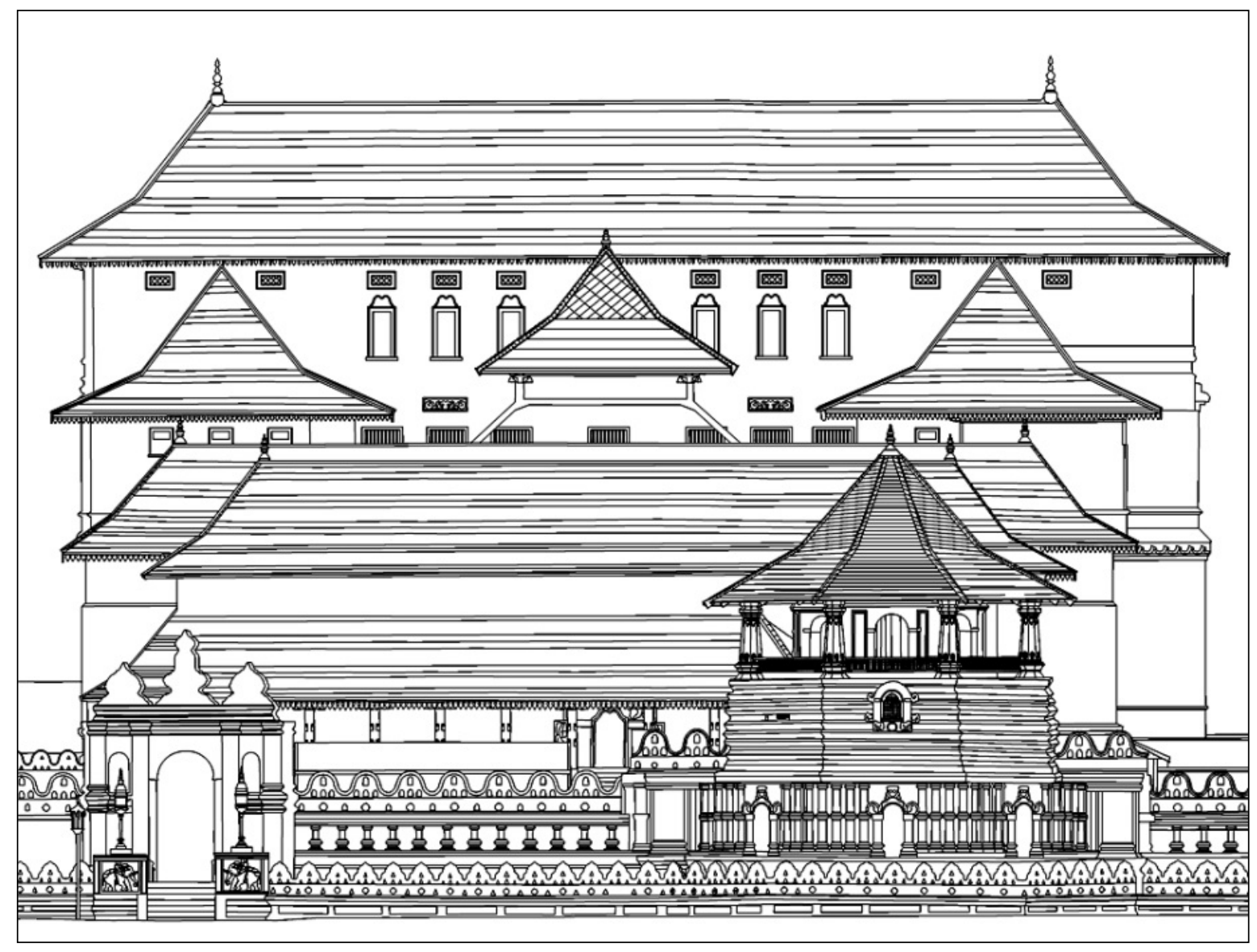

Fig. 7. Elevation of the west façade (detail)

\subsection{Visualisations}

The TLS-data were exported to Autodesk ReCAP and *.las-Files both containing texture information and can be used as a basis for 3D-visualisations. Furthermore, these files can be used for regular visualisations like camera flights through the point cloud. A first video with a camera flight from the main entrance following the way up to the inner temple and around the shrine (Fig. 9) was done already. The video will expand soon by adding camera flights through the octagon, drumbeating corridor and through the park around the audience hall.

For the animations with more effects and solid surfaces the scan data is the basis for digital rebuilding in correct proportions. Therefore, the textured models of the moonstones can be used, too. 


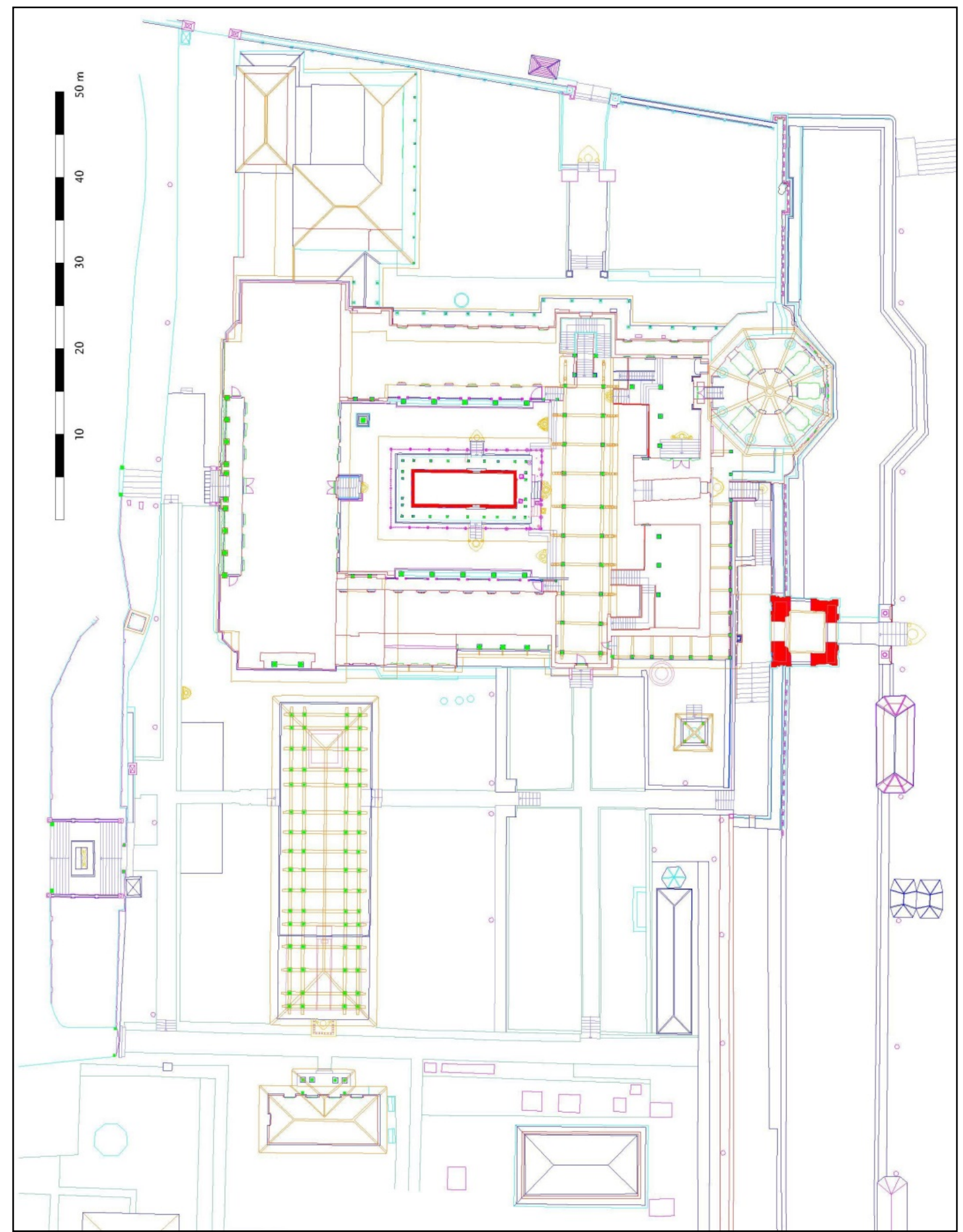

Fig. 8. Sri Dalada Maligawa. Ground floor plan 


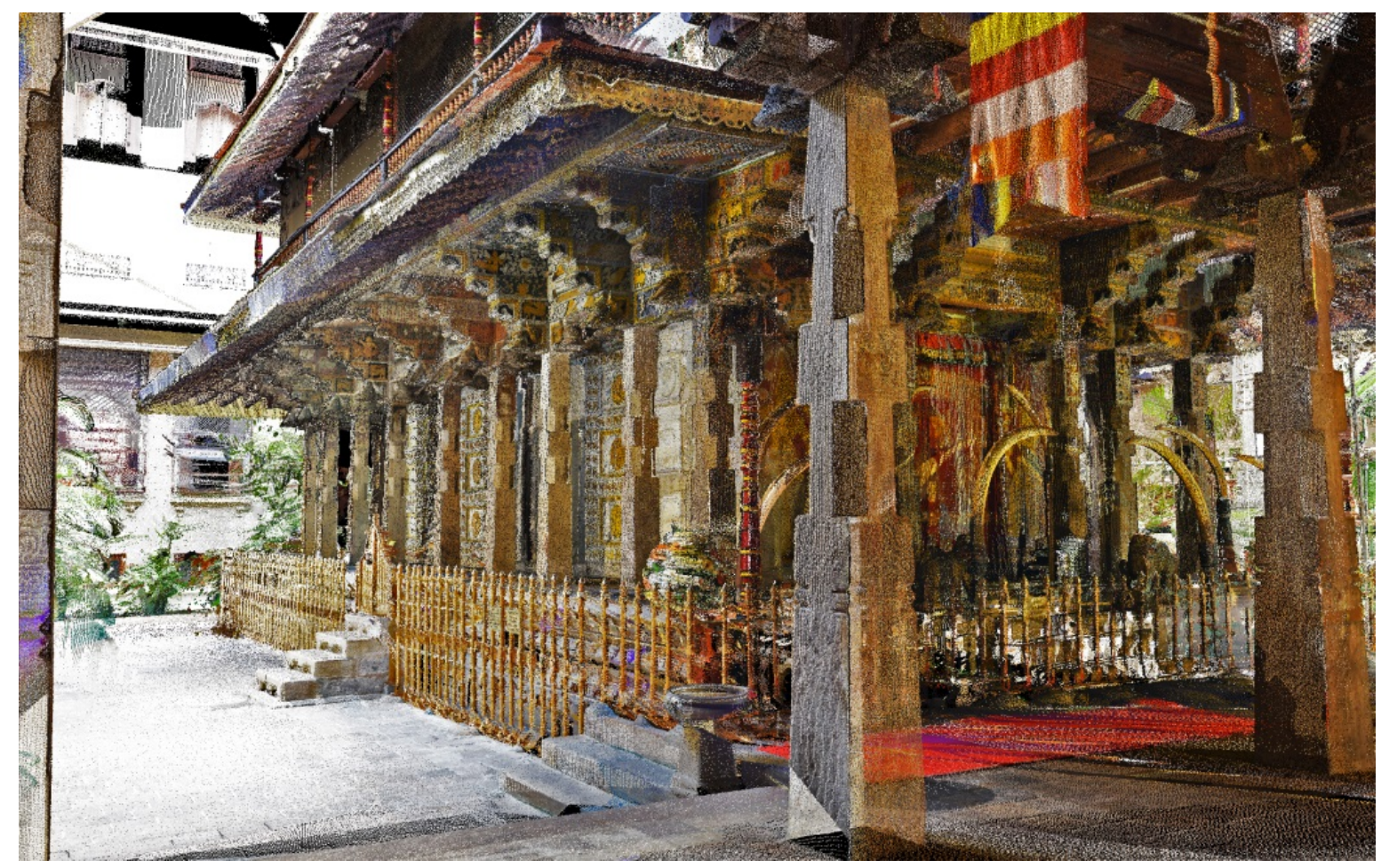

Fig. 9. Point cloud rendering of shrine and courtyard

\section{Transfer of knowledge}

Teaching the local specialist staff during the project duration worked well. Especially in the fieldwork the newcomers understand the handling of the techniques immediately and internalised the workflow. After a short time they were able to scan parts of the area on their own without any assistance.

But there were also complications especially during the post-processing and further analysis. For example, a short travel budget does not allow effective and sufficiently detailed transfer of knowledge over a longer period. Therefore, most of communication has to be done by mail or phone leading to delays or misunderstanding, because of the language barriers. Another unexpected but big problem was the transfer of data between Germany and Sri Lanka. At the end we had to send USB-Sticks by ordinary airmail and had to accept a long delivery time to avoid network administrator restrictions on the one hand and slow, unstable internet connections on the other hand.

\section{Outlook}

Despite limited resources the project has been a success and an important milestone for ongoing preservation of the cultural treasure of the Sri Dalada Maligawa.

The high resolution TLS-data build a basis for comprehensive site monitoring. More CAD-drawings and analysis of the data will be done by the Special Projects and Media Bureau in cooperation with local project partners to complete the documentation of as-build drawings. All following animations, 3Dvisualisations and projects will use the recorded scan data. Records of all data are going to be stored and archived at the temple and the involved research institutes. 
Processing high quality textured surface models directly basing on the TLS-data will be tested after the project duration. Because of the limited time, the complexity of the geometry and the data size a realisation was not possible during the project. The output would provide much better conditions for further visualisations.

To complete the documentation of missing parts we will look forward to scan these areas in an additional project. There is the need to complete the measuring of some area of the inner temple like the main façade of the shrine, the monks' quarters, the temple administration, the kitchen and the museum. The documentation should also involve the adjacent temples in the west and historical buildings around the area of Sri Dalada.

For a smooth operation of the follow-up projects contact has been established with the University of Kelaniya and the Central Cultural Fund of Sri Lanka. Both institutions are eagerly interested in a cooperation especially for a further transfer of knowledge. In addition, the documentation of the missing parts and the generating of missing CAD-Plans is in the focus of the future cooperation. Therefore, several periodic workshops about handling multiple techniques on site and about processing the data are planned. These workshops will be held in Sri Lanka directly on site at the temple in Kandy and at Kelaniya University as well as at the Centre for Heritage Conservation Studies and Technologies (KDWT) at the University of Bamberg.

During the workshops it is also planned to examine and closely map structural damages at Sri Dalada Maligawa. With a repeated 3D-documentation of endangered surfaces and building parts and a later 3D-comparison of the different campaigns site monitoring will be achieved.

Based on the recently finalized first project and with the encouraging outlook for further projects we hope to be able to contribute greatly to the preservation of this unique interreligious cultural and spiritual centre for future generations.

\section{Acknowledgements}

We wish to express our gratitude and appreciation to the German Federal Foreign Office for funding this project as part of the Cultural Preservation Programme. Special thanks and acknowledge is due to the German embassy in Colombo for their great support and also to the other project partners involved like the Media and Special Projects Bureau of Sri Dalada Maligawa, Format4plus GmbH, Infosurv Lanka (Pvt) Ltd and Format4asia (Pvt) Ltd for their invaluable contribution and cooperation throughout the project. At least the authors would like to thank Riegl LMS especially Mr. Andreas Hofstötter for their generous and straightforward support. 


\section{References}

Bellendorf, P., 2011. Hochaufgelöste 3D-Dokumentation mittelalterlicher Oberflächen. In: Bennewitz, I., Schindler, A., Farbe im Mittelalter. Materialität - Medialität - Semantik. Band I, Berlin.

Coningham, R./Lewer, N., 1999. Paradise Lost: The bombing of the Temple of the Tooth - a UNESCO World Heritage site in Sri Lanka. Antiquity, 73, pp 857-866.

De Silva, T. K. N. P., 1985. Temple of the Tooth, Kandy. Architecture, Sculpture, Painting, Colombo.

De Silva, T. K. N. P., 1994. Kandy - A World Heritage City, Colombo.

Eckstein, G., 1999. Empfehlungen für Baudokumentationen - Bauaufnahme - Bauuntersuchung, Stuttgart.

Gonizzi Barsanti, S., Remondino, F., Visintini, D., 2013. 3D Surveying and Modeling of archaeological sites - some critical issues. In: ISPRS Annales of the Photogrammetry, Remote Sensing and Spatial Information Sciences, Strasbourg, France, Vol. II-5/W1, pp 145-150.

Grussenmeyer, P., Landes, T., Doneus, M., Lerma, J.L., 2016. Basics of Range-Based Modelling Techniques in Cultural Heritage 3D-Recording. In: Stylianidis, E., Remondino, F., 3D Recording, Documentation and Management of Cultural Heritage, Dunbeath.

IBM, 2015. Exhibition of the International Buddhist Museum (IBM) at Kandy, Sri Lanka.

Riedel, A., Henze, F., Marbs, A., 2011. Paradigmenwechsel in der historischen Bauforschung? Ansätze für eine effektive Nutzung von 3D-Informationen. In: Heine, K., Rheidt, K., Henze, F., Riedel, A., Von Handaufmass bis High Tech III. 3D in der historischen Bauforschung, Darmstadt/Mainz.

Seneviratna, A., 1987. The Temple of the Sacred Tooth Relic - An Architectural History of the Dalada Maligawa - The Symbol of the Buddhist Faith and Sovereignty in Sri Lanka, Colombo.

Stylianidis, E., Georgopoulos, A., Remondino, F., 2016. Basics of Image-Based Modelling Techniques in Cultural Heritage 3D Recording. In: Stylianidis, E., Remondino, F., 3D Recording, Documentation and Management of Cultural Heritage, Dunbeath.

Wiedemann, A., 2004. Handbuch Bauwerksvermessung. Geodäsie - Photogrammetrie Laserscanning, Basel. 


\subsection{Der Bamberger Kaisersaal - Neue Möglichkeiten für eine} kunsthistorische Analyse historischer Prunkräume

Am Beispiel des heiligen Zahntempels in Kandy konnte eindrücklich präsentiert werden, welchen Nutzen die Verwendung von berührungslosen und zerstörungsfreien Messmethoden in der Dokumentation historischer Gebäudekomplexe liefert. Während der fünfwöchigen Kampagne konnten alle notwendigen Daten für die Erstellung von CAD-Bestandsplänen auf der Grundlage von 3D-Punktwolken generiert werden. Eine zusätzliche Aufwertung der TLS-Daten liefert darüber hinaus die Kombination der 3D-Vermessung mit hochauflösenden, farbechten Fotografien. Hierdurch lassen sich realistische, texturierte 3D-Oberflächenmodelle von Gebäuden oder Gebäudeabschnitten erstellen, welche als Grundlage für wissenschaftliche Arbeiten der Kunstgeschichte, Restaurierung/ Konservierung und Bauforschung dienen.

Hierzu wurde ein Workflow entwickelt, der künftig ressourcensparend in der Zusammenarbeit von Fotograf*innen und Vermesser*innen im Projekt Corpus der barocken Deckenmalerei in Deutschland $(\mathrm{CbDD})$ der bayerischen Akademie der Wissenschaften angewendet werden wird, um herausragende barocke Deckenmalereien in ihrer Raumstruktur für kunstwissenschaftliche Analysen zu erfassen. Als Basisstudie dienten der Kaisersaal und weitere Räume der Neuen Residenz in Bamberg. Die Digitalisierung der barocken Prunksäle fand 2016 statt, in Kooperation mit dem CbDD, im Rahmen der Masterarbeit von Victoria Spicale M.A. im Masterstudiengang Denkmalpflege an der Universität Bamberg unter der Betreuung von Prof. Dr. Rainer Drewello. Die technische Betreuung der Arbeit sowie die weiterführende Aufbereitung der Daten und Ausarbeitung des Workflows erfolgte durch den Verfasser. 
Publikation 2: Praxistaugliche Digitalisierung barocker Prunkräume - hochauflösende 3D-

\section{Dokumentation des Kaisersaals der Neuen Residenz in Bamberg (Rahrig 2019b)}

Der Artikel ist hier als Post-Print in einem angepassten Layout wiedergegeben. Für eine korrekte Zitierweise und Seitenzahlen, bitte die Originalquelle verwenden:

Rahrig, M.: „Praxistaugliche Digitalisierung barocker Prunkräume.“ In: Hoppe, S. / Locher, H. / Burioni, M. (Hg.): Digitale Raumdarstellung: Barocke Deckenmalerei und Virtual Reality, (Computing in Art and Architecture, Band 4), Heidelberg, arthistoricum.net, 2020, S. 327-347, Doi: https://doi.org/10.11588/arthistoricum.774.

Praxistaugliche Digitalisierung barocker Prunkräume

Die hochauflösende dreidimensionale Vermessung historischer Objekte bietet vielseitige Möglichkeiten für ihre Dokumentation, Archivierung und Erforschung. Häufig zielt der Einsatz dieser Techniken jedoch nur auf einzelne Fragestellungen ab wie bspw. die Erstellung von Bestandsplänen oder die museale Präsentation. Am Beispiel des Kaisersaals der Neuen Residenz in Bamberg mit seinem einzigartigen Ensemble barocker Architektur und Malerei wurde ein Verfahren zur Kombination von Laserscandaten und hochauflösen den Fotografien getestet. Das Ziel liegt in der Erstellung eines einzelnen 3D-Modells, welches für eine Vielzahl verschiedener Fragestellungen genutzt werden kann. So kann der gesamte Raum virtuell begangen werden, wodurch Kunsthistoriker die Interaktion zwischen Malerei und Architektur analysieren können. Zusätzlich lassen sich aber auch detaillierte CAD-Pläne für Architekten, Bauforscher und Restauratoren erstellen. An beliebigen Stellen lassen sich CAD-Schnittlinien erzeugen. Durch die Erstellung von Orthofotos können verzeichnungsfreie Wandund Deckenansichten erstellt werden.

Neben einer exakten virtuellen 3D-Abbildung des aktuellen Zustands eines Objektes lassen sich mit der verwendeten Methodik auch historische Zustände visualisieren, welche sich sonst nur aus historischen Quellen ableiten ließen. Im Falle des Bamberger Kaisersaals konnte die schrittweise Ausgestaltung des Saals rekonstruiert werden. Die Visualisierung solcher Zwischenstände kann dabei helfen, neue Aufschlüsse zur Motivation und Inspiration des Künstlers, aber auch zum Arbeitsablauf der Ausgestaltung historischer Objekte zu erarbeiten.

\section{Einführung}

Herkömmliche Methoden zur Dokumentation von Architektur sind stark an die jeweilige Fragestellung der Auftrag gebenden Fachdisziplin gebunden. Bauforscher, Restauratoren und Architekten bspw. benötigen maßhaltige, verformungsgerechte CAD-Pläne eines Objektes. Diese umfassen Ansichten, Grundrisse und Schnittzeichnungen. Im Falle farblich gefasster Wand- und Deckenflächen werden hierzu häufig verzeichnungsfreie Orthofotos der jeweiligen Bereiche erstellt, auf deren Grundlage Befund- und Schadenskartierungen, Maßnahmenplanungen und weitergehende Arbeiten erfolgen 
können. Kunsthistoriker, Museologen oder Wahrnehmungspsychologen hingegen benötigen meist eine detailreiche Erfassung des Raumgefüges einschließlich seiner Proportionen und Lichtverhältnisse, um den Raum erfahrbar zu machen. Raumansichten (Fotografien oder virtuelle Darstellungen) müssen hierzu die gesamte Komposition des Raums, das Zusammenspiel von Wand-, Decken- und Bodengestaltung sowie die Ausstattung des Raums präzise wiedergeben.

Für beide Varianten der Dokumentation wird zum Teil ein großer zeitlicher, technischer und personeller Aufwand betrieben. An herausragenden Objekten führt dies häufig zu einer doppelten oder gar dreifachen Dokumentation, um allen Fachdisziplinen gerecht zu werden. Wünschenswert wäre folglich eine ressourcensparende Dokumentationsform, die für alle Anwendungsbereiche verwendbar ist. Als Lösungsvorschlag wird im Folgenden ein möglicher Workflow über den kombinierten Einsatz von 3D-Laserscanning und hochauflösender Fotografie am Beispiel des Kaisersaals der Neuen Residenz in Bamberg vorgestellt. ${ }^{177}$

\section{Der Bamberger Kaisersaal im Zentrum der Forschung}

Der Kaisersaal (Abb. 01) ist der wohl bedeutendste Raum der Neuen Residenz in Bamberg, welche als fürstbischöfliche Oberhofhaltung ab 1695 am Domplatz errichtet wurde. Fürstbischof Lothar Franz von Schönborn, der zugleich Kurerzbischof von Mainz und Reichskanzler der deutschen Länder war, veranlasste beim Bau der Residenz die Errichtung einer Gastwohnung für Besuche des Kaisers. ${ }^{178} \mathrm{Hier}$ bildet der Kaisersaal den ersten und zugleich größten Raum in der Raumabfolge des kaiserlichen Appartements. Er wird unmittelbar von dem repräsentativen Treppenaufgang erschlossen und war im höfischen Zeremoniell von zentraler Bedeutung. ${ }^{179} 1707$ beauftragte Lothar Franz von Schönborn den Maler Melchior Steidl mit der Ausführung eines prächtigen Deckengemäldes. In den Jahren bis 1709 folgte die Ausgestaltung der Wandflächen, ebenfalls durch Steidl. Auf den Wandflächen zwischen den Fenstern zeigt der Raum bis heute ein ungemein prächtiges Bildwerk mit Kaiserportraits aus dem Hause der Habsburger, antiken Kaiserportraits oberhalb der Fensterreihe sowie von Kaiser Heinrich II. ${ }^{180}$ Über der reich gestalteten Fensterzone schließt eine nicht weniger aufwändige Architekturmalerei an, die den Übergang von der Wand- zur Deckenmalerei bildet. Über einem illusionistisch auskragenden Gesims rahmt die Architektur das zentrale Deckengemälde. In den Ecken des Raums werden die vier Weltreiche dargestellt. Eine Ecke nimmt die assyrisch-babylonische

\footnotetext{
${ }^{177}$ Besonderer Dank gilt Frau Victoria Spicale für die Anfertigung der 3D-Scans im Rahmen ihrer Masterarbeit und das zur Verfügung stellen ihrer Dokumentation für den vorliegenden Aufsatz. Ferner sei den beteiligten Kollegen des KDWT für ihre Unterstützung gedankt, hier besonders Rainer Drewello und Leander Pallas. Weiterer Dank gilt dem CbDD sowie der Bayerischen Schlösserverwaltung für die gelungene Kooperation. 178 Johannes Erichsen, Die Kaiserwohnung der Bamberger Residenz - Zweckbestimmung und Bildprogramm, in: Johannes Erichsen et al., KaiserRäume - KaiserTräume - [...], Hirmer, München 2007, S. 34-53, hier S. 35. 179 Erichsen 2007, S.37ff.; Ute Engel: Augentäuschung und Illusionskunst in der barocken Deckenmalerei, in: Andreas Beitin / Roger Diederen (Hg): Lust der Täuschung. [...] , Kat. Ausst. München / Aachen 2018 / 2019, München 2018, S. 168-179, hier S. 168-173.

${ }^{180}$ Erichsen et al. 2007, S. 215ff.
} 
Monarchie ein, die zweite die persische Monarchie, komplementiert werden diese durch die Darstellungen des griechischen und des römischen Weltreichs. Das zentrale Deckenbild schließlich zeigt eine Allegorie der göttlichen Weisheit, einen Triumphzug der Divina Providentia als eine den Raum überspannende Szene. Die qualitätsvolle, farbenprächtige, illusionistische Malerei erzeugt durch ihre geschickt gewählten Perspektiven einen deutlich höheren Raumeindruck, als man es in einem nur sieben Meter hohen Saal vermuten würde. ${ }^{181}$

Dieses herausragende Objekt barocker Bildkunst ist Forschungsgegenstand des von der Bayerischen Akademie der Wissenschaften geförderten Projektes Corpus der barocken Deckenmalerei in Deutschland (CbDD), unter der Leitung von Stephan Hoppe. ${ }^{182} 2015$ wurde ein Pilotprojekt Deckenmalerei und 3D initiiert, an dem sich das Kompetenzzentrum für Denkmalwissenschaften und Denkmaltechnologien der Universität Bamberg beteiligte. Im Rahmen dessen erfolgten Studien zu verschiedenen Möglichkeiten der dreidimensionalen Dokumentationsmethoden für barocke Prunkräume.

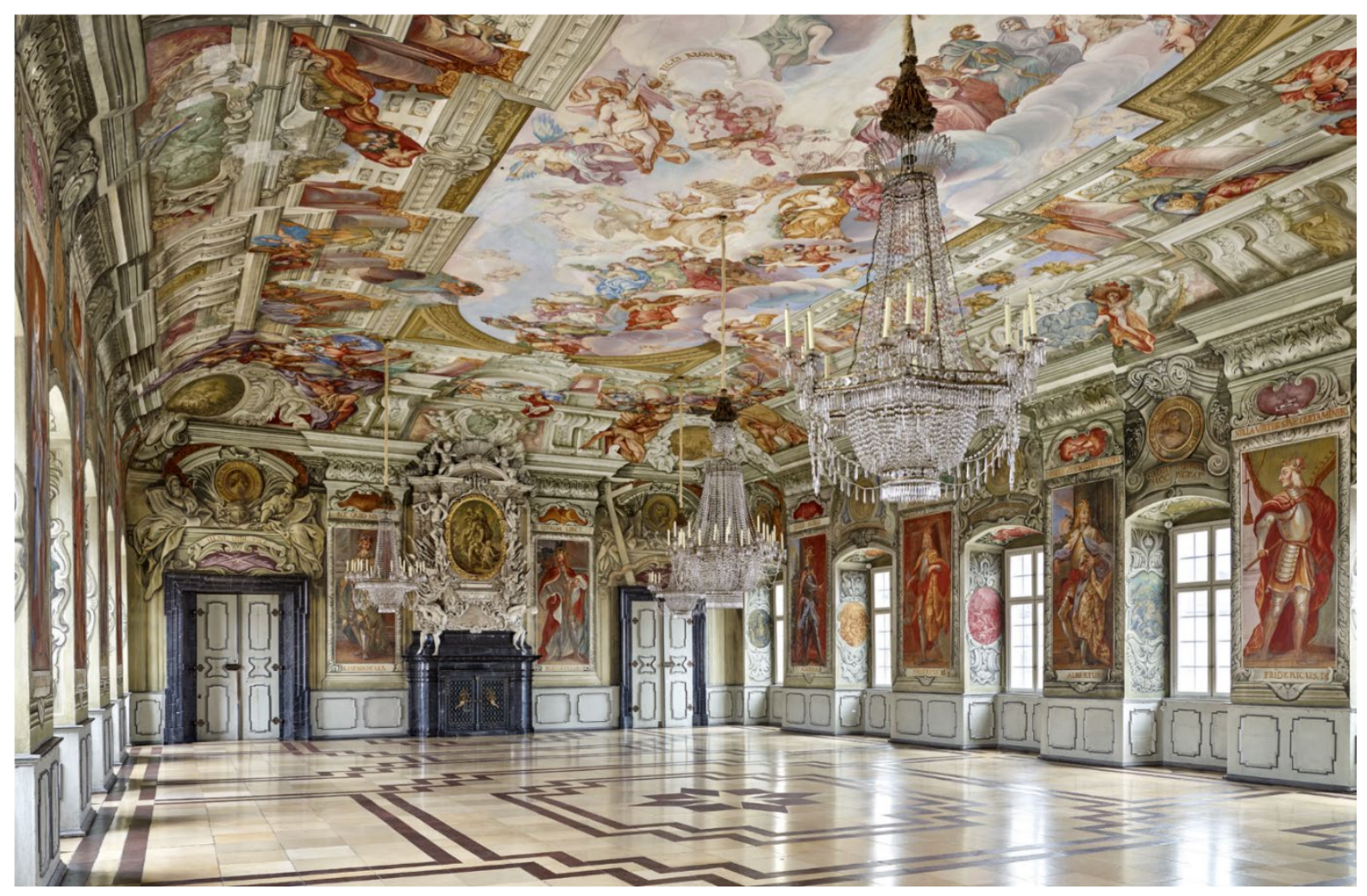

Abb. 01: Kaisersaal, Inneres, Bamberg, Neue Residenz (Bildarchiv Foto Marburg / Bayerische Schlösserverwaltung / Thomas Scheidt, Christian Stein (CbDD)).

\footnotetext{
${ }^{181}$ Vgl. Erichsen 2007, S. 41ff, Erichsen et al. 2007, S. 215ff und Christian Dümler, Die Neue Residenz in Bamberg - Bau- und Ausstattungsgeschichte der fürstbischöflichen Hofhaltung im Zeitalter der Renaissance und des Barock, Degener, Neustadt / Aisch 2001, hier S. 172ff.

182 Für nähere Information zum CbDD siehe bspw. https://deckenmalerei.badw.de/ das-projekt.html.
} 


\section{Datenaufnahme im Bamberger Kaisersaal}

Die Oberflächendokumentation des Bamberger Kaisersaals erfolgte im Zuge der Abschlussarbeit von Victoria Spicale im Masterstudiengang Denkmalpflege / Heritage Conservation der Universität Bamberg. ${ }^{183}$ Zum Einsatz kam ein terrestrischer 3D-Laserscanner (TLS) der Firma RiegI LMS (Rieg| VZ400i). Das Gerät arbeitet nach dem Prinzip der single-pulse, time-of-flight Messung. ${ }^{184}$ Hierbei werden einzelne Laserimpulse vom Gerät ausgesendet. Nachdem diese von einer umgebenden Oberfläche reflektiert und zum Scanner zurückgesendet werden, können Lage und Entfernung der Oberfläche zum Gerät ermittelt und so einzelne Punkte mit 3D-Koordinaten gemessen werden. Durch die Rotation des Scanners in $360^{\circ}$ um die eigene Achse und einem integrierten, rotierenden Spiegel können die Laserimpulse horizontal in $360^{\circ}$ und vertikal in $100^{\circ}$ ausgesendet werden. Hierdurch lässt sich mit dem Scanner die gesamte Umgebung in einer Distanz bis zu 800 m hochpräzise mit einer Auflösung bis zu $3 \mathrm{~mm}$ vermessen. Oberhalb der Scaneinheit des Geräts lässt sich eine digitale Spiegelreflexkamera montieren. Durch ihre Aufnahmen können die gemessenen 3D-Punkte später mit einem Farbwert verknüpft werden. ${ }^{185}$ Systembedingt werden bei einer Scanposition die Bereiche oberhalb und unter- halb des Gerätes nicht erfasst, welche ohnehin durch das Stativ des Scanners und der aufgesetzten Kamera verdeckt sind. Mit dieser Methode kann nicht durch Objekte hindurch gemessen werden, wodurch Lücken im Scan entstehen, die durch eine Verknüpfung zusätzlicher Scanpositionen geschlossen werden müssen. Im Falle des Kaisersaals wurden insgesamt elf Scanpositionen an verschiedenen Stellen im Raum angefertigt, um Verschattungen durch die Lüster und Bestuhlung auszugleichen sowie alle Fensternischen vollständig zu erfassen. Die Vermessung des Kaisersaals erfolgte zusammen mit weiteren Räumen an drei Tagen im Juni 2016 tagsüber zu regulären Besuchs- und Öffnungszeiten der Neuen Residenz.

\section{Datenverarbeitung}

Die einfachste oder schnellste Möglichkeit, um die Daten auszuwerten, ist die Verwendung einer 3DPunktwolke der Einzelscans, bei der jedem Punkt ein Farbwert, basierend auf den Fotografien des Scanners, zugeordnet wird (Abb. 02). Der Raumeindruck lässt sich hierdurch schnell darstellen und die Punktwolken lassen sich unproblematisch in AutoCAD $^{\odot}$ oder anderen CAD-Anwendungen importieren, um dort beispielsweise verformungsgerechte Vektorzeichnungen zu erstellen. Bei einer

\footnotetext{
${ }^{183}$ Victoria Spicale, Topographische Aufnahmeanalyse barocker Decken - Methodenvergleich am Beispiel von Prunkräumen der Neuen Residenz Bamberg, unveröffentlichte Abschlussarbeit im Masterstudiengang Denkmalpflege / Heritage Conservation, Universität Bamberg, Bamberg 2016.

${ }^{184}$ Für ausführliche Informationen zur Funktionsweise von terrestrischen Laserscannern und ihrem Einsatz in der Denkmalpflege siehe Pierre Grussenmeyer, Tania Landes, Michael Doneus, José Luis Lerma, Basics of Range-Based Modeling Techniques in Cultural Heritage 3D Recording, in Efstratios Stylianidis, Fabio Remondino (Hg.), 3D Recording, Documentation and Management of Cultural Heritage, Whittles Publishing, Dunbeath 2016, S. 305-368.

${ }^{185} \mathrm{Vgl}$. Technisches Datenblatt, Riegl VZ400i: http://www.riegl.com/uploads/tx_pxpriegldownloads/RIEGL_VZ400i_Datasheet_2020-10-06.pdf.
} 
detaillierten Betrachtung der Punktwolken jedoch erweisen sich die Lücken zwischen den einzelnen gemessenen Punkten als störend. Eine Verknüpfung der Einzelpunkte zu einem Oberflächenmodell ist daher der notwendige nächste Schritt, um die Raumstruktur gezielt analysieren zu können.

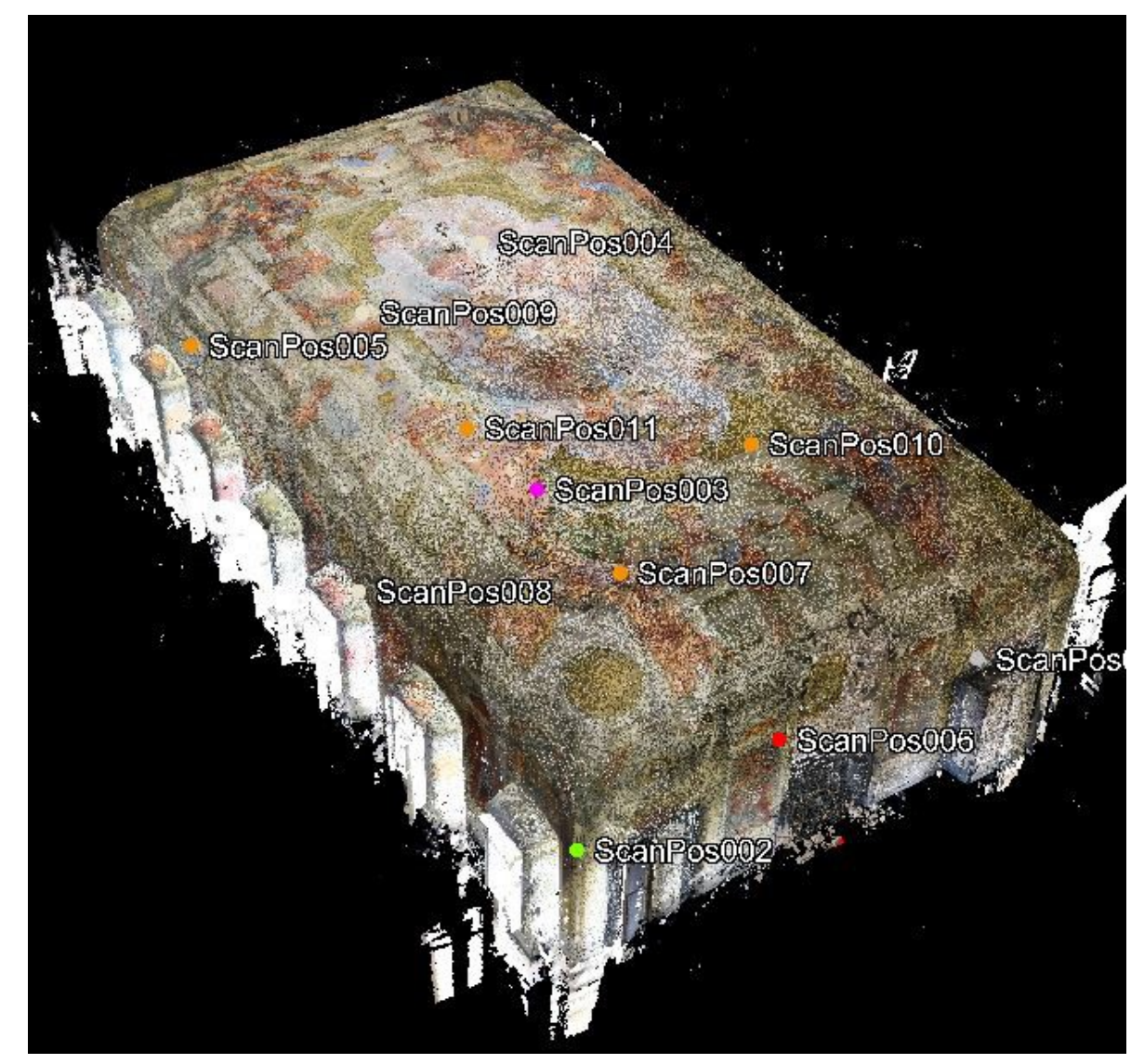

Abb. 02: Punkwolkenansicht des Bamberger Kaisersaals (Max Rahrig).

\section{Vertex Textur}

Bei einem aus den Punktwolken generierten Oberflächenmodell fallen schnell Unstimmigkeiten und Fehler in der Textur auf. Zum Beispiel werden Farbwerte der im Raum hängenden Lüster auf dahinterliegende Flächen projiziert (Abb. 03). Diese Stellen müssen daher zunächst in den Punktwolken der Einzelscans von Hand selektiert und gelöscht werden, bevor die einzelnen Scanpositionen miteinander verknüpft werden. Im Anschluss erhält man ein bereinigtes 3DOberflächenmodell des Raums. Die Säuberung der Daten kann dabei bspw. in der scannereigenen Software erfolgen, die Verknüpfung der Einzelscans zu einem Oberflächenmodell - die Triangulation - anschließend bspw. über MeshLab ${ }^{186}$ oder Geomagic Wrap ${ }^{\odot}$.

\footnotetext{
186 Paolo Cignoni, Marco Callieri, Massimiliano Corsini, Mateo Dellepiane, Fabio Ganovelli, Guido Ranzuglia, MeshLab: an Open-Source Mesh Processing Tool, in: Sixth Eurographics Italian Chapter Conference, Salerno 2008, S. 129-136.
} 


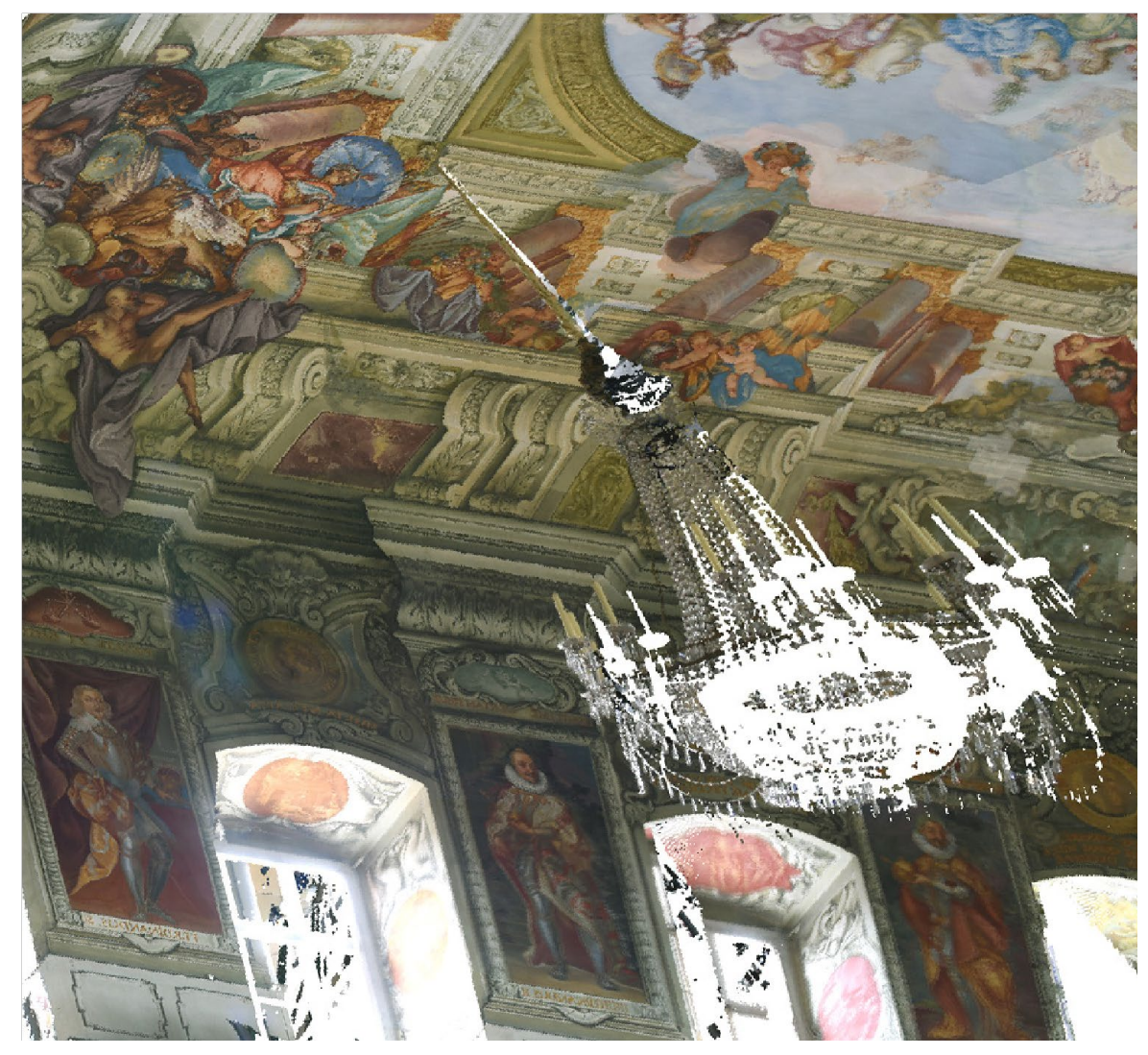

Abb. 03: Kronleuchter auf Wand projiziert. Texturfehler vor der Optimierung der Vertex Textur (Victoria Spicale).

Das hieraus resultierende 3D-Modell spiegelt die Geometrie des Raums und die Farbigkeit der Oberflächen wider. Bei einer detaillierten Betrachtung wird jedoch schnell ersichtlich, dass der Farbeindruck nur sehr grob und unbefriedigend für die detaillierte Betrachtung ist (Abb. 04). Es fehlen jegliche Details, welche für eine Dokumentation der Malerei oder die Bestands- und Zustandskartierungen nötig sind. Der Grund hierfür ist die verwendete Methode für die Berechnung der Textur: Bei der sogenannten Vertex-Kolorierung wird bei der Triangulation, der Verknüpfung der gemessenen 3D-Punkte zu einem Oberflächenmodell, der jeweilige Farbwert der Punkte für die Einfärbung der Dreiecke genutzt, sodass jeder einzelnen Dreiecksfläche ein Farbwert zugewiesen wird. ${ }^{187}$ Dabei wird der Farbwert gegebenenfalls sogar gemittelt, sofern die drei Punkte unterschiedliche Werte aufweisen. Somit wird die Auflösung der Textur maximal so hoch wie es das zugrundeliegende Oberflächenmodell zulässt. Bei einem Oberflächenmodell eines Raums wie dem Kaisersaal liegt die Auflösung etwa bei $1 \mathrm{~cm}$. Die Qualität der Darstellung mag für eine Präsentation im Internet ausreichen, für eine Vermittlung oder wissenschaftliche Bearbeitung / Auswertung der historischen Oberflächen genügt dies aber bei Weitem nicht. Für die detaillierte Betrachtung und Bewertung des Bestandes ist eine deutlich höhere Texturqualität notwendig. Abhilfe bietet ein sogenanntes Texture Mapping, welches im Folgenden näher beschrieben wird.

\footnotetext{
187 Diego Cantor, Brandon Jones, WebGL Beginner's Guide, Packt Publishing, Birmingham 2012, S. 51.
} 


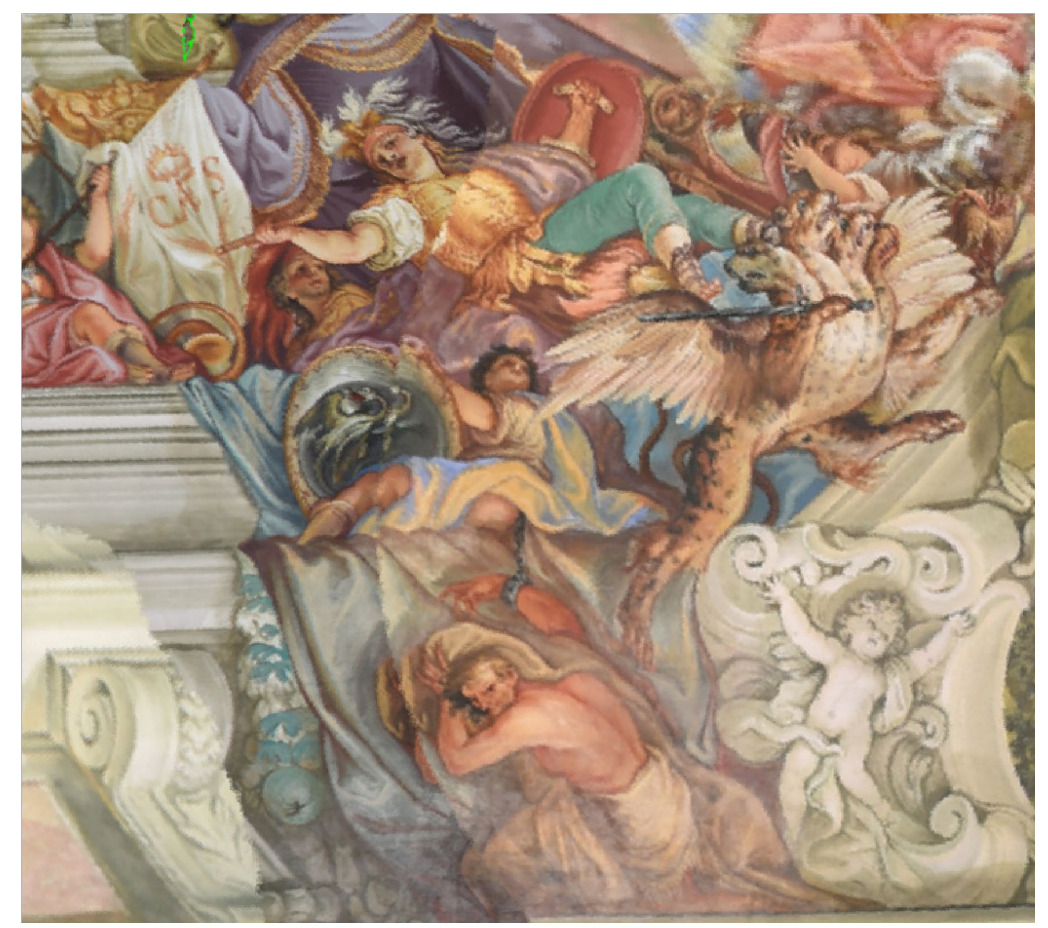

Abb. 04: Detailansicht der finalen Vertex Textur. Die Unschärfe ergibt sich aus der Zuweisung eines einzelnen Farbwertes pro Dreiecksfläche des 3D-Modells. (Victoria Spicale).

\section{Texture Mapping}

Beim Texture Mapping ist die Textur von der Geometrie getrennt. Nach Erstellung des Oberflächenmodells werden die Fotografien wie eine dünne Haut über das 3D-Modell gelegt. Dies geschieht unabhängig von der zugrundeliegenden Größe und Oberflächenauflösung des 3D-Modells, wodurch es möglich ist, eine deutlich höhere Detailgenauigkeit und Auflösung in der Farbinformation wiederzugeben. Es gibt eine Vielzahl an Möglichkeiten, um ein 3D- Modell mit Texture Mapping zu erstellen. ${ }^{188} \mathrm{Im}$ Falle des Bamberger Kaisersaals erfolgte zunächst die Erstellung eines detailreichen Oberflächenmodells mit der Software QTSculptor ${ }^{\odot}$ (QTS). Neben Riegl-Scandaten können hier auch Daten anderer Scannerhersteller eingelesen werden. ${ }^{189}$

\footnotetext{
${ }^{188} \mathrm{Vgl}$. José Luis Lerma et al., Terrestrial laser scanning and close range photogrammetry for 3D archaeological documentation: the Upper Palaeoloithic Cave of Parpalló as a case study, in: Journal of Archaeological Science 37, Elsevir, 2010, S. 499-507, DOI: 10.1016/j.jas.2009.10.011; José Luis Lerma et al., Integration of Laser Scanning and Imagery for Photrealsitic 3D Architectural Documentation, in: Chau-Chang Wang (Hg.): Laser Scanning, Theory and Applications, Rijeka 2011, S. 413-430, DOI: 10.5772/14534; Fabio Remondino, Heritage Recording and 3D Modeling with Photogrammetry and 3D Scanning, in: Remote Sensing, 2011 (3), S. 11041138, DOI: 10.3390/ rs3061104; Sharaf Al-kheder et al., Developing a documentation system for desert palaces in Jordan using 3D laser scanning and digital photogrammetry, in: Journal of Archaeological Sciences 36, Elsevir, 2009, S. 537-546, DOI: 10.1016/j.jas.2008.10.009; Sehr frühe Workflows zur Kombination von Scandaten und hochauflösenden Fotografien sind zu finden bei Jean-Angelo Beraldin et al., Virtualizing a Byzantine Crypt by Combining High-resolution Textures with Laser Scanner 3D Data, in: Proceedings of the 8th International Conference on Virtual Systems and Multimedia, 2002, S. 3-14 und Sabry El-Hakim et al., Effective 3D Modeling of Heritage Sites, in: The 4th International Conference of 3D Imaging and Modeling, 2003, S. 302309, DOI: 10.1109/IM.2003.1240263.

${ }^{189}$ So können zusätzlich Scandaten von Z+F sowie Daten der PT-M Scanner von Polymetric, für dessen Daten die Software eigentlich entwickelt wurde, eingelesen und verarbeitet werden.
} 
Beim Importieren der Riegl-Daten werden die Scanpositionen mit ihren einzelnen Dateien gespeichert. Es stehen somit sowohl die 3D-Punktwolken als auch die jeweiligen hochauflösenden Fotografien zur weiteren Bearbeitung zur Verfügung. Der Vorteil an dem Verfahren mit dieser Software liegt in der vergleichsweise einfachen und automatisierten Optimierung der Scandaten.

Bedingt durch die verwendete Technik entstehen beim Scannen zahlreiche ungewollte Messpunkte: Trifft der Laserstrahl bspw. auf eine Kante oder eine spiegelnde Oberfläche, wird der Laserstrahl aufgefächert und mehrfach reflektiert. Diese zusätzlich gemessenen Punkte werden als Streupunkte oder Rauschen bezeichnet (Abb. 05). Diese Messfehler sollten vor der weiteren Bearbeitung herausgefiltert werden. In QTS geschieht dies durch den Befehl » Detect Jump Edges «, wobei zuvor die Filterparameter über die Optionen angepasst werden können. ${ }^{190}$

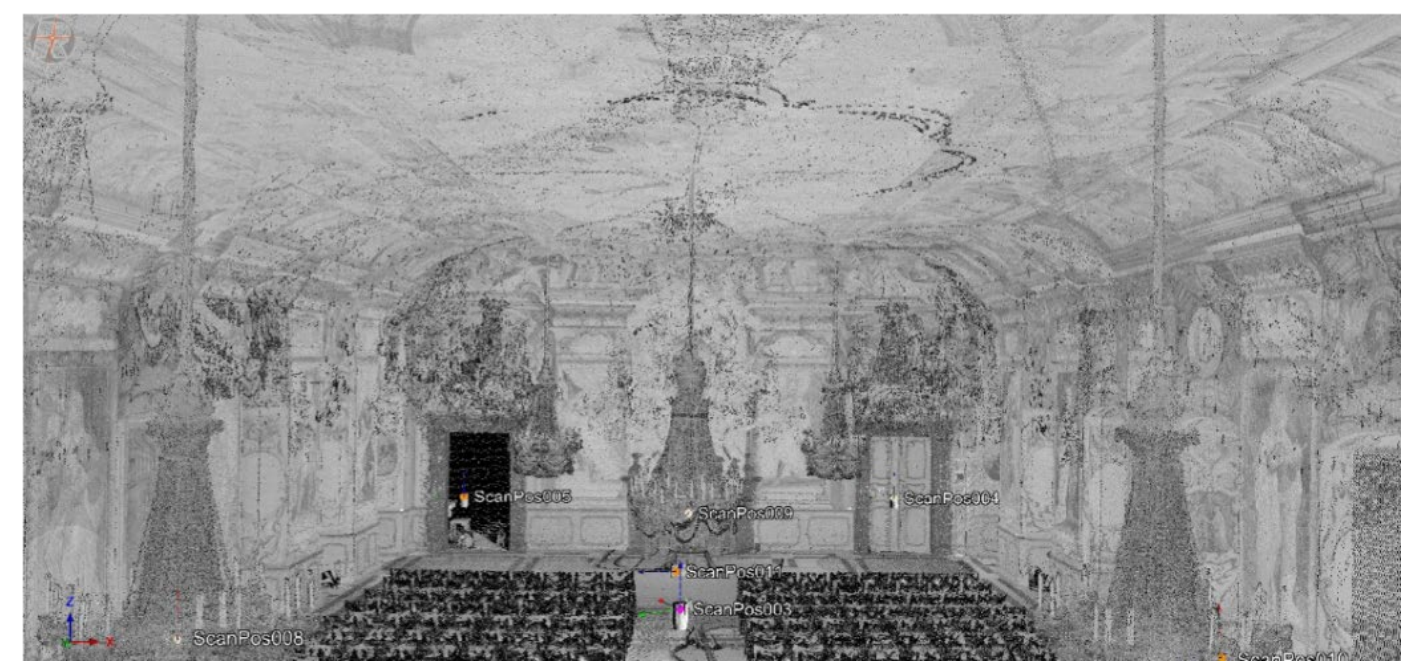

Abb. 05: Deutlich sind Messfehler entlang der Kronleuchter zu sehen (Max Rahrig).

Nachdem die einzelnen Scans gefiltert wurden, kann die Orientierung der Scans weiter optimiert werden. Hierzu stehen Best-Fit-Prozesse zur Verfügung, mit denen die Punktwolken der einzelnen Scans anhand der Geometrie der Gesamtheit der gemessenen Punkte bestmöglich zueinander ausgerichtet werden. Durch die Angabe der maximalen Abweichung und der durchschnittlichen Standardabweichung kann das Ergebnis zusätzlich zu einer optischen Begutachtung überprüft werden. ${ }^{191}$

Die Vielzahl der einzelnen Scanpositionen ist notwendig, um den Raum möglichst lückenlos zu dokumentieren. Da der Scanner jedoch in der Regel einen kompletten $360^{\circ}$-Scan erstellt, werden diverse Oberflächen mehrfach von verschiedenen Positionen erfasst und vermessen. Zwar bilden diese redundanten Daten die Grundlage für die Best-Fit-Ausrichtung der Scans zueinander, doch sind sie für die weitere Bearbeitung unerwünscht, da sie nur unnötig das Dateivolumen vergrößern. Durch den

\footnotetext{
${ }^{190}$ VgI. ISRA VISION Polymetric GmbH, Quick Reference Guide - QTSculptor V 6.0. 11.12.2017 v1.1, S. 16.

${ }^{191}$ Vgl. Polymetric 2017, S. 22.
} 
Befehl » Redundancies « können die redundanten Daten herausgefiltert werden. Dabei berücksichtigt die Software bei der Anwendung des Filters auch die Qualität der Daten: So werden vorzugsweise Scanpunkte behalten, die möglichst orthogonal vom Scanner gemessen wurden, um mögliche Messfehler durch ein Auffächern des Laserstrahls zu reduzieren. Ebenso werden Punkte bevorzugt, die von einem Standpunkt näher zur Oberfläche oder in einem engeren Punktabstand und damit in einer höheren Auflösung erfasst wurden. ${ }^{192}$

Im weiteren Verlauf der Datenverarbeitung werden gegebenenfalls weitere unerwünschte Bereiche manuell maskiert und ausgeblendet. Der Kaisersaal musste bspw. bei vollständiger Bestuhlung vermessen werden. Die Klappstühle sollen dagegen im Endmodell nicht enthalten sein. Auch die kristallenen Kronleuchter wurden herausgefiltert. Nachdem alle Messfehler, redundanten Daten und unerwünschten Bereiche maskiert und herausgefiltert wurden, folgt die Berechnung des Oberflächenmodells durch eine Verknüpfung der einzelnen Punkte zu Dreiecksflächen. Die Software interpoliert hierbei automatisch mögliche Löcher und Fehlstellen im 3D-Modell. Einzelne Lücken treten bspw. im Bereich der Kamine mit ihren vergleichsweise sehr plastischen Oberflächen auf. In anderen Programmen erfolgt diese Arbeit meist durch manuelles, semi-automatisches Löcher-Füllen, was sehr zeit- und damit auch kostenintensiv ist. Am Ende dieser Prozesskette mit QTS entsteht ein lückenloses hochauflösendes 3D-Modell des Raums, bisher jedoch noch ohne Farbinformation (Abb. 06).

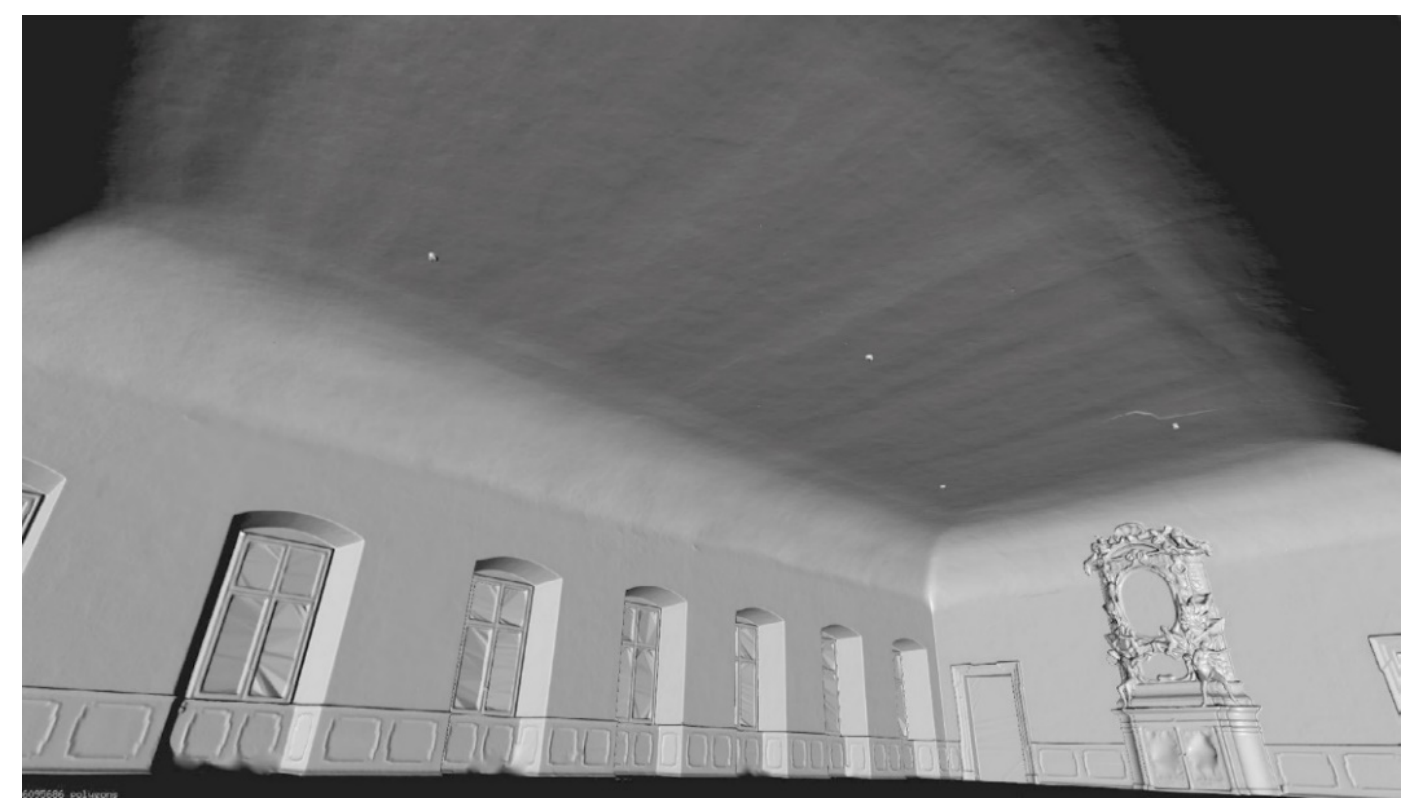

Abb. 06: Das bereinigte 3D-Oberflächenmodell, ohne Farbinformation (Max Rahrig).

\section{Variante 1}

Um das eigentliche Texture Mapping zu berechnen, sollen im Folgenden zwei Vorgehensweisen beschrieben werden. Die erste Variante dient der Texturierung mit einzelnen Fotografien, die zweite greift auf Bildserien zurück. Wenn nur Teilbereiche eines 3D-Modells texturiert werden sollen oder nur

\footnotetext{
${ }^{192}$ Vgl. Polymetric 2017, S. 16, 22.
} 
einzelne Fotos zur Verfügung stehen, kann mittels QTS in wenigen Schritten ein hochwertiges Ergebnis berechnet werden. Es lassen sich beliebige Fotografien in QTS importieren, sie können im Zuge des Scanvorganges, aber auch zu einem anderen Zeitpunkt mit einer Digitalkamera aufgenommen werden. Die Fotografien müssen nach dem Importieren zum 3D-Modell orientiert werden. Hierzu wird eine Ansicht des 3D-Modells generiert, die möglichst identisch den Bereich der zu orientierenden Fotografie abbildet. Anschließend können zwischen Fotografie und 3D-Ansicht Tie-Points gesetzt werden (Abb. 07): sogenannte natürliche Passpunkte oder homologe Punkte, die in beiden Ansichten eindeutig zu identifizieren sind. Je nach Komplexität und Größe des Ausschnitts sollten 6 bis 15 Punktpaare für die Orientierung gesetzt werden. Innerhalb der Fotografie werden anschließend Kanten in die Geometrie des 3D-Modells eingeblendet, wodurch die Orientierung des Fotos einfach zu überprüfen ist.

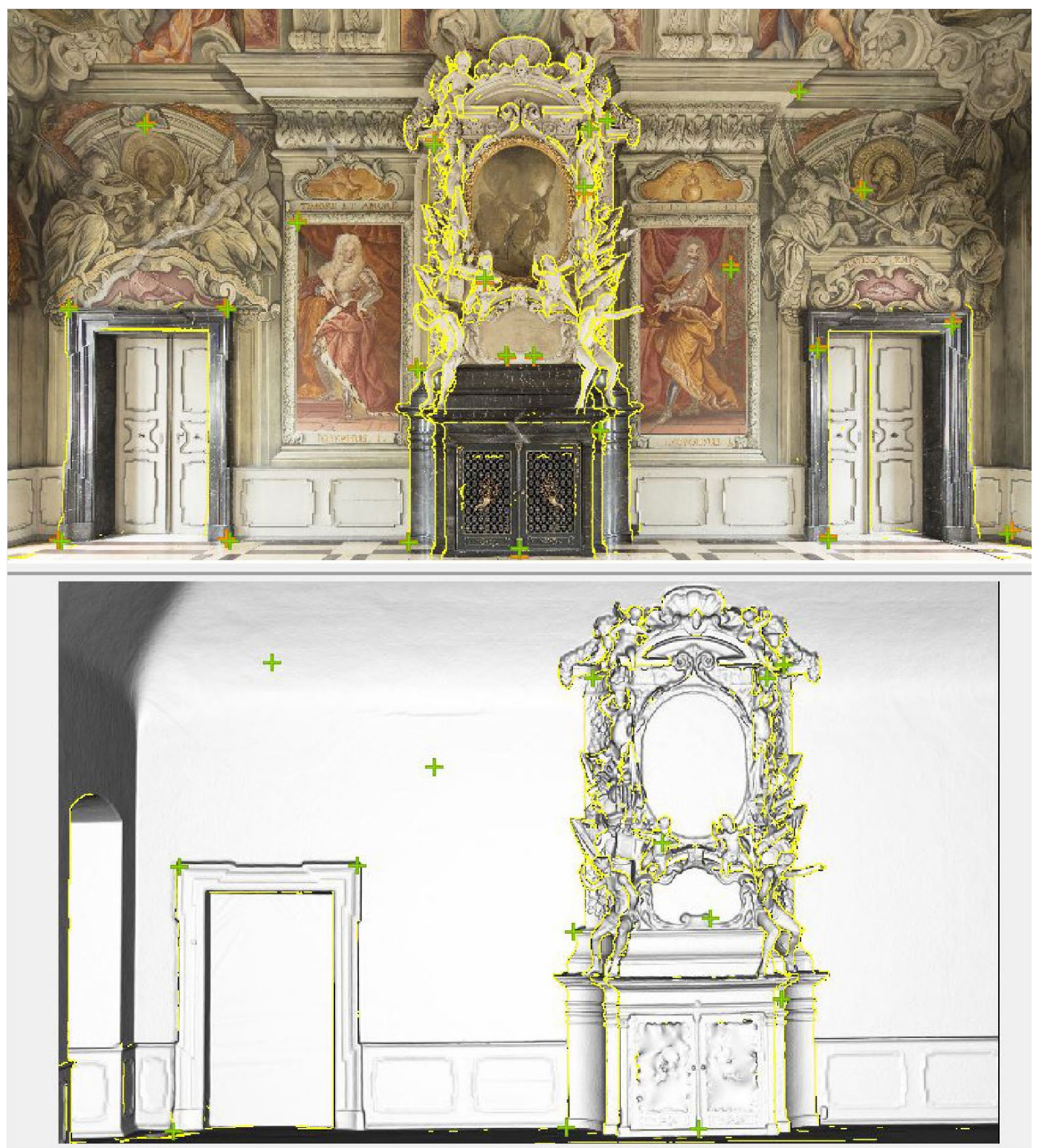

Abb. 07: Tie-Points zur Verortung der Fotos auf dem 3D-Modell (Max Rahrig). 
Auf diese Weise werden schrittweise alle Fotografien mit dem 3D-Modell verknüpft. Anschließend sollten überlappende Bereiche, die in mehreren Fotografien sichtbar sind, maskiert und auf einen möglichst kleinen Überlappungsbereich reduziert werden, um mögliche Dopplungsfehler aufgrund minimaler Abweichungen zwischen den Bildorientierungen zu reduzieren (Abb. 08). Im Falle des RieglScanners lassen sich die Fotografien - aufgrund der vorkalibrierten Kameraposition auf dem Scanner - direkt orientiert zu den 3D-Daten importieren, sodass unmittelbar mit der Maskierung begonnen werden kann. Im Arbeitsprozess kann das Ergebnis immer wieder durch eine schnelle Berechnung der Textur in einer geringen Qualität überprüft und anschließend gegebenenfalls Abweichungen nachjustiert werden. Sollten hierbei Farbabweichungen zwischen den Fotografien erkannt werden, lassen sich diese einfach in Bildbearbeitungsprogrammen wie Adobe Photoshop $\subsetneq$ oder GIMP ${ }^{193}$ ausgleichen. Hierbei ist darauf zu achten, dass Anzahl und Seitenverhältnis der Pixel nicht verändert werden und die Fotografie unter dem identischen Dateinamen abgespeichert wird. Die angepasste Fotografie kann anschließend als unkomprimierte JPG-Datei wieder importiert werden, wobei bei diesem Vorgang das fehlerhafte Foto automatisch ersetzt wird.

Nachdem die Fotografien angepasst worden sind, kann eine hochauflösende Textur berechnet werden. Hierzu wird die Auflösung auf den Maximalwert von 16.384 Pixeln Kantenlänge gesetzt und der Befehl » Compute Texture " gestartet. Das Ergebnis kann als OBJ oder VRML exportiert werden. Der große Vorteil dieser Variante besteht darin, dass auch einzelne Fotografien, aus denen kein zusammenhängender Bildverband (s.u.) gerechnet werden kann, für die Texturierung genutzt werden können.

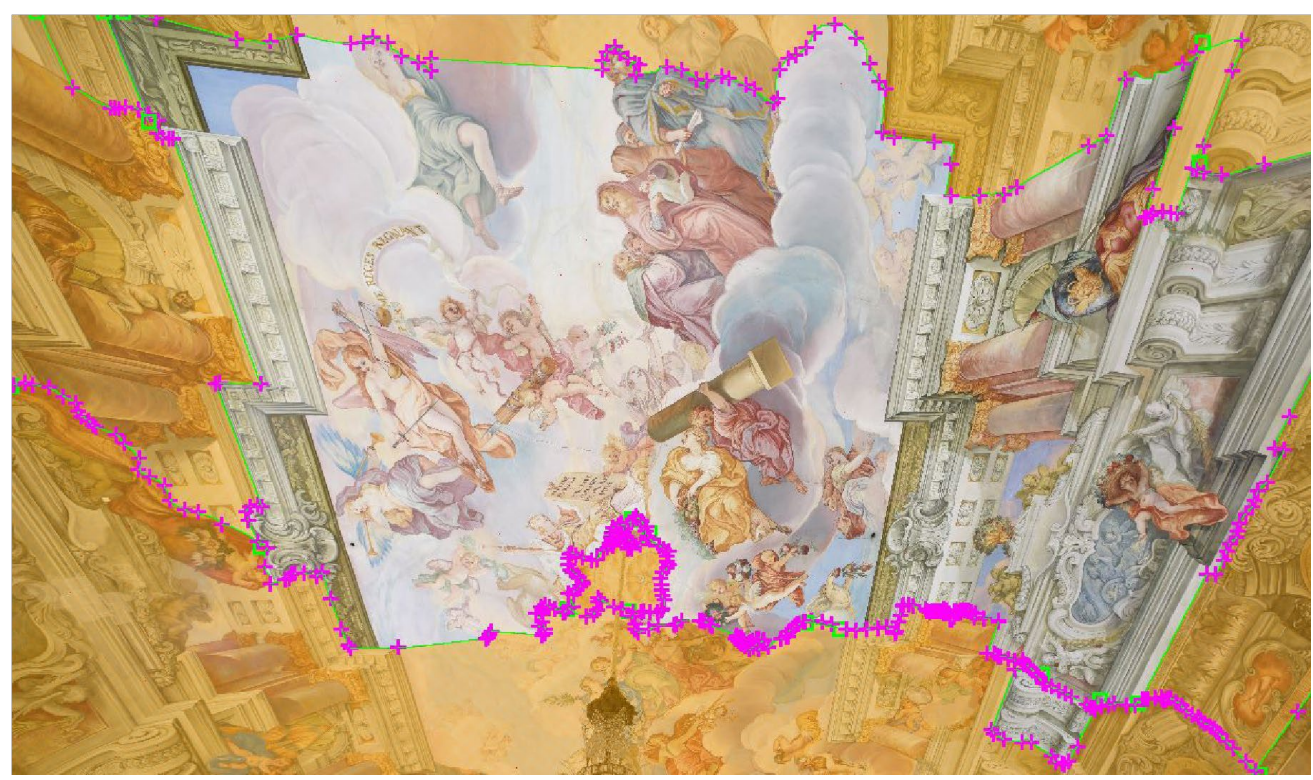

Abb. 08: Gelb maskierte Bereiche der Fotografie werden für die Berechnung der Textur nicht verwendet (Max Rahrig).

\footnotetext{
${ }^{193}$ Siehe: https://www.gimp.org (CC BY-SA 4.0)
} 


\section{Variante 2}

Die zweite Möglichkeit, ein hochauflösendes Texture Mapping zu generieren, erfolgt mittels ImageBased-Modelling oder Structure-from-Motion. Diese Verfahren dienen eigentlich der Generierung von 3D-Modellen unmittelbar aus Bildserien, ohne dass ein terrestrischer Scan angefertigt werden muss. Da die hochwertige illusionistische Architekturmalerei im Bamberger Kaisersaal jedoch zu fehlerhaften 3D-Modellen führen kann - die Software berechnet Geometrie aus der Malerei heraus - soll der Bildverband für dieses Beispiel nur zur Texturierung des 3D-Modells vom Scanner dienen. ${ }^{194} \mathrm{Im}$ Falle des Kaisersaals wurde daher die vom Riegl-Scanner angefertigte Fotoserie zusammen mit einzelnen Fotografien des Corpus der barocken Deckenmalerei in Deutschland in das Programm Photoscan $^{\circledast} /$ Metashape $^{\odot}$ der Firma Agisoft importiert.

Bei einem solchen Verfahren erfolgt die Orientierung und Ausrichtung der Einzelbilder zueinander standardmäßig mittels » Alignment «: Anhand starker Überschneidungen zwischen den Fotos werden automatisch identische Bereiche ermittelt und so die einzelnen Aufnahmepositionen der Fotografien zueinander berechnet (Abb. 09). Hierbei unterscheidet die Software in der Skalierung des Objekts zunächst nicht, ob es sich um Makroaufnahmen eines Fingerhuts oder die Bildserie eines Bergmassivs handelt. Um eine korrekte Skalierung der Daten zu erhalten, braucht es die Angabe von Maßen des Objekts. ${ }^{195}$ Zudem soll der Bildverband zum vorhandenen 3D-Modell des Scanners ausgerichtet sein. Hierzu werden markante Bereiche gewählt, die sowohl in den Fotografien, als auch in den 3D-Modellen sichtbar sind. Dies können bspw. Passpunkte des Scanners, aber auch Kanten von Profilen oder markante Bereiche der Wandmalerei sein. In der Scanner-Software können die 3D-Koordinaten diese Punkte abgelesen und als Referenzpunkte in Photoscan ${ }^{\circledR} /$ Metashape $^{\circledR}$ übertragen werden (Abb. 10). Wenn die Referenzpunkte in mindestens drei Fotografien markiert sind, werden sie in den verbleibenden Fotos automatisch detektiert. Im Falle des Kaisersaals erfolgte die Berechnung der Textur aus ca. 130 einzelnen Aufnahmen.

Nachdem die Skalierung und Ausrichtung des Bildverbandes über die Passpunkte prozessiert ist, kann das untexturierte 3D-Modell des Laserscans importiert werden. Es sollte nun deckungsgleich mit dem Bildverband ausgerichtet sein. Je nach Qualität der Einzelfotos kann nun unmittelbar die Textur berechnet werden. Im Bamberger Kaisersaal wurden die Fotografien tagsüber aufgenommen. Hierdurch mussten unterschiedliche Belichtungszeiten angesetzt werden, um sowohl die Farbigkeit

\footnotetext{
194 Patrick Lackner, Qualitativer Vergleich des 3D-Laserscannings mit dem »Structure from Motion « Verfahren. Unveröffentlichte Abschlussarbeit im Masterstudiengang Denkmalpflege / Heritage Conservation, Universität Bamberg, Bamberg 2017, S. 66.

${ }^{195}$ Für ausführliche Informationen siehe auch Efstratios Stylianidis, Andreas Georgopoulos, Fabio Remondino, Basics of Image-Based Modeling Techniques in Cultural Heritage 3D Recording, in: Efstratios Stylianidis, Fabio Remondino (Hg.), 3D Recording, Documentation and Management of Cultural Heritage, Whittles Publishing, Dunbeath 2016, S.253-304.
} 
des gesamten Raums als auch die Malereien in den deutlich helleren Fensterlaibungen einheitlich wiederzugeben. Deshalb war es notwendig, die einzelnen Aufnahmen in Photoscan ${ }^{\odot} /$ Metashape $^{\odot} \mathrm{zu}$ maskieren, um zu helle oder zu dunkle Bereiche bei der Berechnung der Textur auszugrenzen. Auf diesem Wege konnten auch die Kronleuchter und die Bestuhlung maskiert und herausgefiltert werden. Im Gegensatz zur oben beschriebenen Variante 1 können einheitliche ausgeleuchtete Fotos identische Bereiche für die Textur aufweisen, sodass der Aufwand zum Maskieren und Filtern auch bei größeren Bildserien überschaubar bleibt.

Zur Berechnung des Texture Mappings gibt es auch in Photoscan ${ }^{\odot} /$ Metashape $^{\odot}$ die Möglichkeit, zunächst ein schnelles Ergebnis mit geringer Qualität zu berechnen, das Ergebnis zu überprüfen und ggf. anzupassen. Wenn alle Anpassungen erfolgt sind, kann ein finales hochauflösendes Texture Mapping berechnet werden. Analog zu QTS kann das Ergebnis als OBJ oder VRML exportiert werden.

Um das zeitaufwändige Maskieren und Filtern der Fotografien zu optimieren, ist es ratsam, die Fotos generell mit einer einheitlichen Ausleuchtung, bei gleichen Kameraeinstellungen und mit einem Color Control Patch wie beispielsweise dem X-Rite ColorChecker aufzunehmen. ${ }^{196}$ So können in der Nachbearbeitung der Fotos die korrekten Farbwerte ermittelt werden und das Ergebnis ist somit deutlich farbechter. ${ }^{197}$ Im Falle des Bamberger Kaisersaals war dieser Prozess bisher nicht möglich. ${ }^{198}$

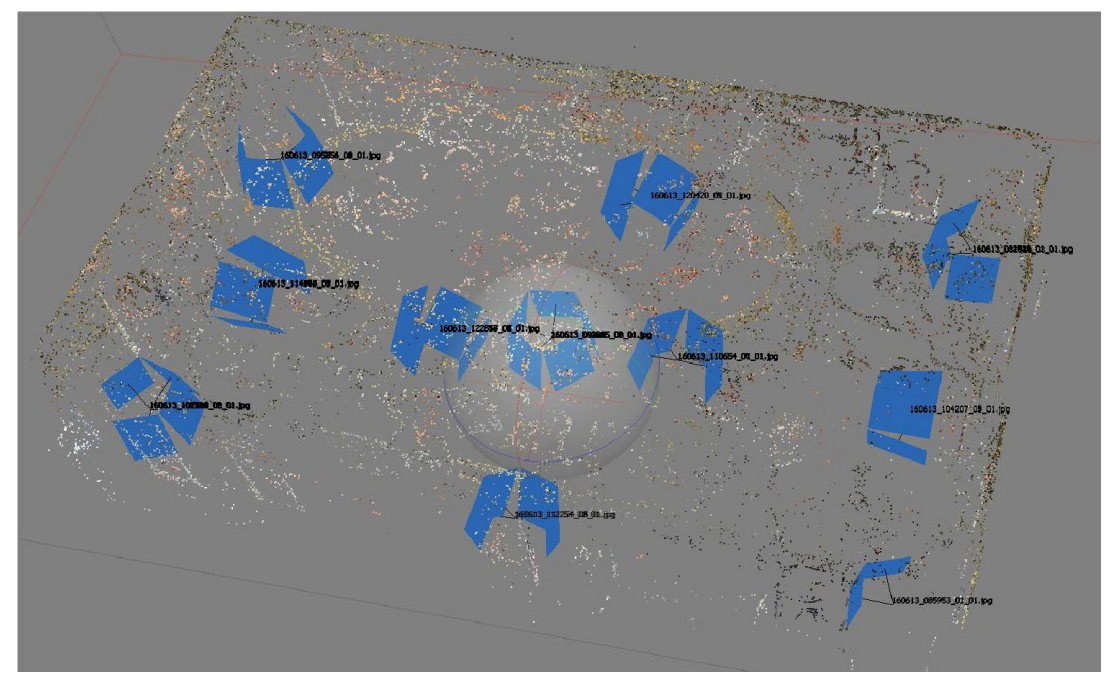

Abb. 09: Bildverband berechnet in Photoscan ${ }^{\odot} /$ Metashape $^{\odot}$. Blaue Flächen stellen die einzelnen Fotoaufnahmen dar (Max Rahrig).

\footnotetext{
196 Jeffrey Warda (Hg.), The AIC Guido to Digital Photography and Conservation Documentation, second edition, American Institute for Conservation, Washington 2011, S. $42 \mathrm{ff}$.

${ }^{197}$ Für detaillierte Informationen zur Aufnahme von Fotoserien für Image-Based Modeling siehe Geert Verhoeven, Basics of Photography for Cultural Heritage Imaging, in: Efstratios Stylianidis, Fabio Remondino (Hg.), 3D Recording, Documentation and Management of Cultural Heritage, Whittles Publishing, Dunbeath 2016, S. 127-251 und Stylianidis et al. 2016.

198 In einer weiteren Kooperation zwischen dem CbDD und dem KDWT konnte eine Dokumentationskampagne in Schloss Arnstorf (Niederbayern) durchgeführt werden, bei der auch eine optimierte Bildserie für den dortigen Kaisersaal aufgenommen wurde.
} 


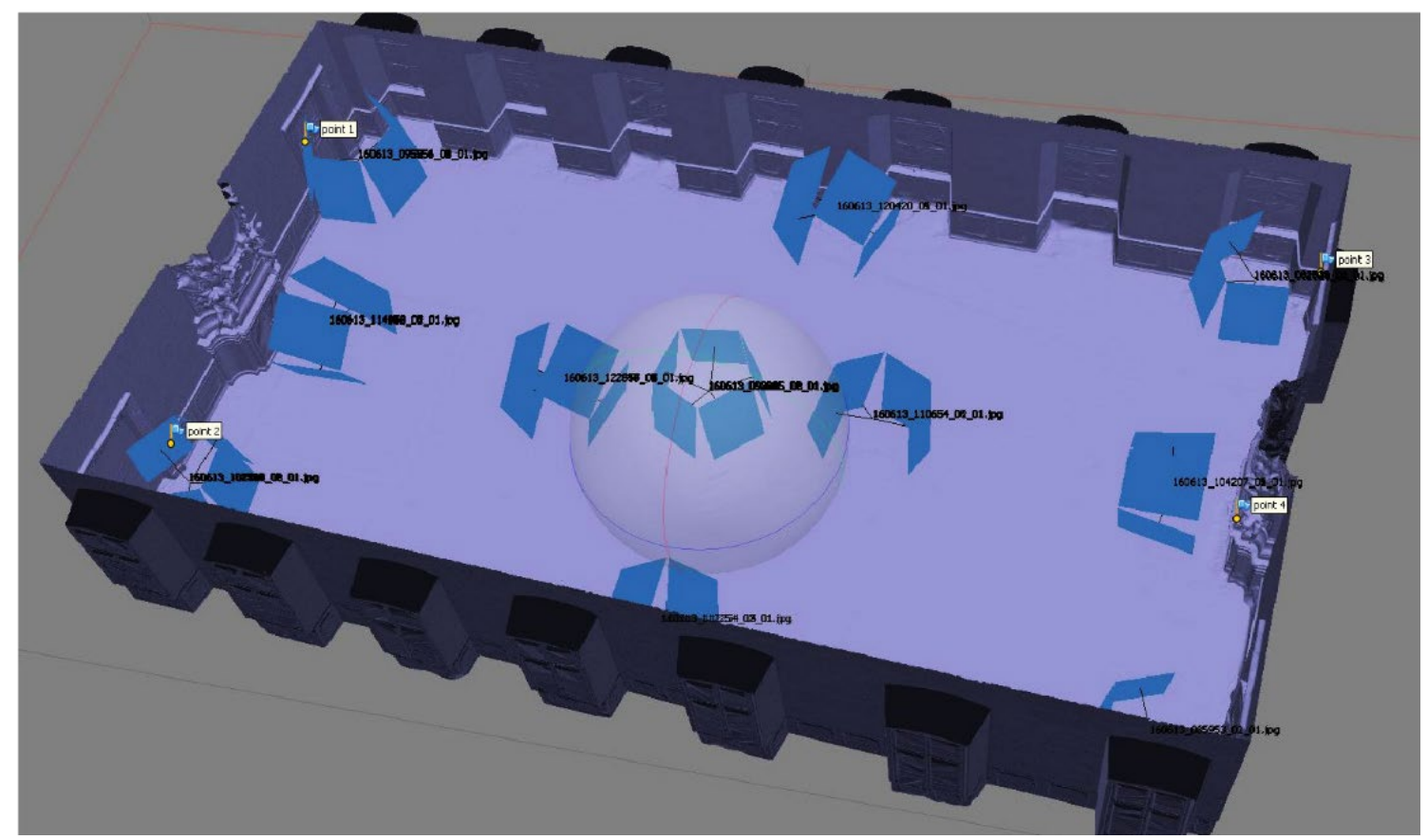

Abb. 10: Bildverband ausgerichtet zum 3D-Modell. Kontrollpunkte (Fähnchen) dienen zur Orientierung und Skalierung des Bildverbandes (Max Rahrig).

\section{Ergebnisse}

Die fertigen 3D-Modelle beider Varianten stehen anschließend zur Auswertung für diverse Fragestellungen zur Verfügung. ${ }^{199} \mathrm{OBJ}$ und VRML können in jede gängige 3D-Software importiert werden. ${ }^{200}$ So ist es möglich, bspw. in MeshLab oder Aspect3 ${ }^{\odot}$ mit wenigen Klicks verzeichnungsfreie Orthoansichten der Wand- und Deckenflächen (Abb. 11) zu berechnen und diese in AutoCAD ${ }^{\odot} z u$ einem vollwertigen Plansatz weiter zu verarbeiten. Dabei können Schnittlinien an jeder beliebigen Stelle und in jedem Winkel generiert und ebenfalls in CAD überführt werden, ohne dass die einzelne Schnittlinie aufwändig von Hand nachgezeichnet werden muss. Durch die im Vergleich zur Vertex Textur deutlich höher auflösende Oberflächendarstellung (Abb. 12) dienen solche Pläne als ausgezeichnete Planungsgrundlage z.B. für Befund- und Schadenskartierungen.

\footnotetext{
${ }^{199}$ Eduardo Zalama, Jaime Gómez-García-Bermejo, José Llamas, Roberto Medina, An effective texture mapping approach for 3D models obtained from laser scanner data to building documentation, in: Computer Aided Civil and Infrastructure Engineering, Vol. 26, 2011, S. 381-392, DOI: 10.1111/j.1467-8667.2010.00699.x.

${ }^{200}$ Max Rahrig, Wohin mit all den Scans? Über die dauerhafte Archivierung von 3D-Daten bedeutender Kulturgüter am Beispiel des Bamberger Kaisergrabs, in: Birgit Franz, Gerhard Vinken (Hg.), Das Digitale und die Denkmalpflege. Bestandserfassung - Denkmalvermittlung - Datenarchivierung - Rekonstruktion verlorener Objekte (= Veröffentlichung des Arbeitskreises Theorie und Lehre der Denkmalpflege e.V., Band 26), Holzminden 2017, S. 130-139, DOI: 10.11588/arthistoricum.263.348, hier S. 137.
} 


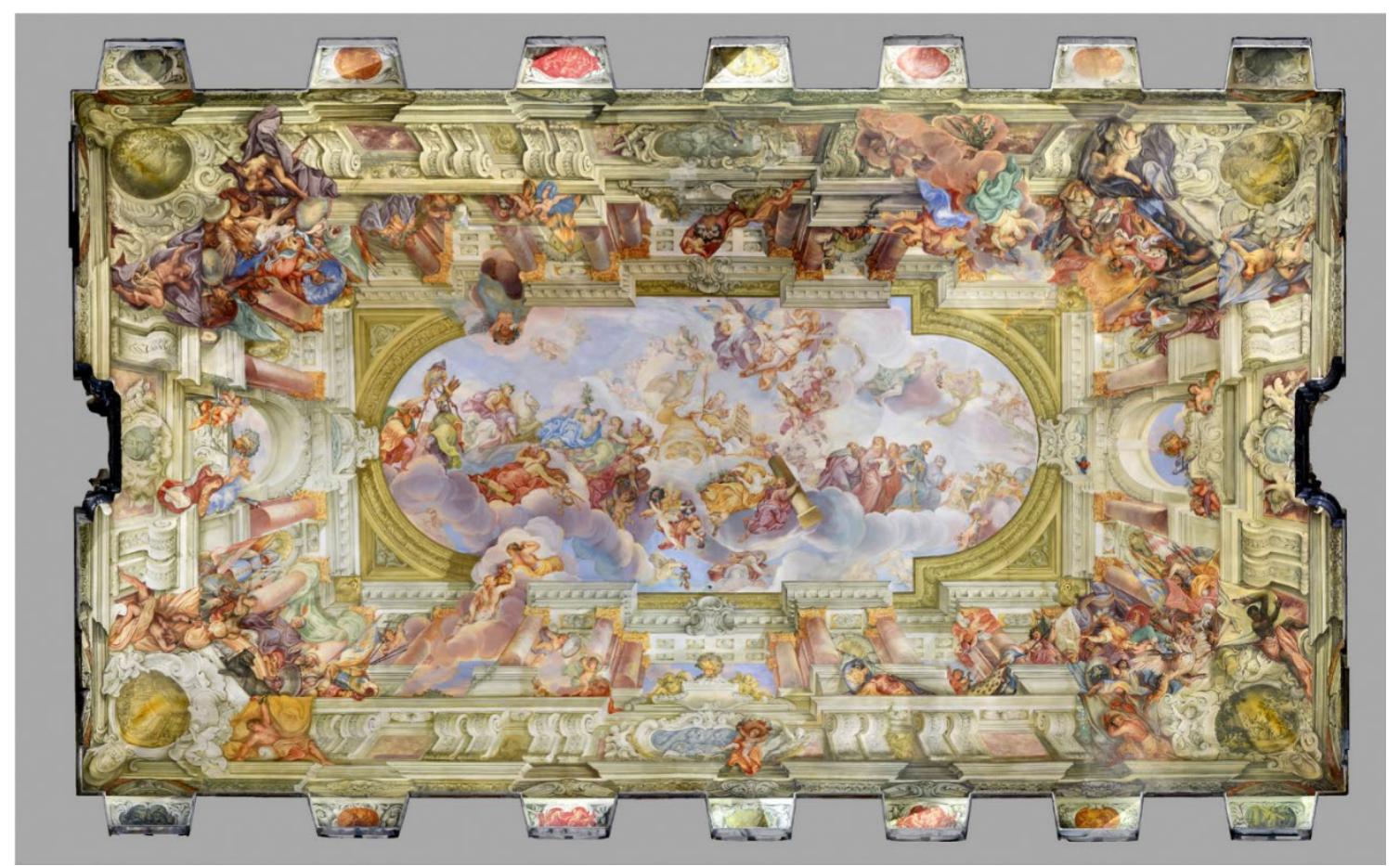

Abb. 11: Orthografische Ansicht des Deckengemäldes im Bamberger Kaisersaal, generiert aus dem 3D-Modell (Max Rahrig)

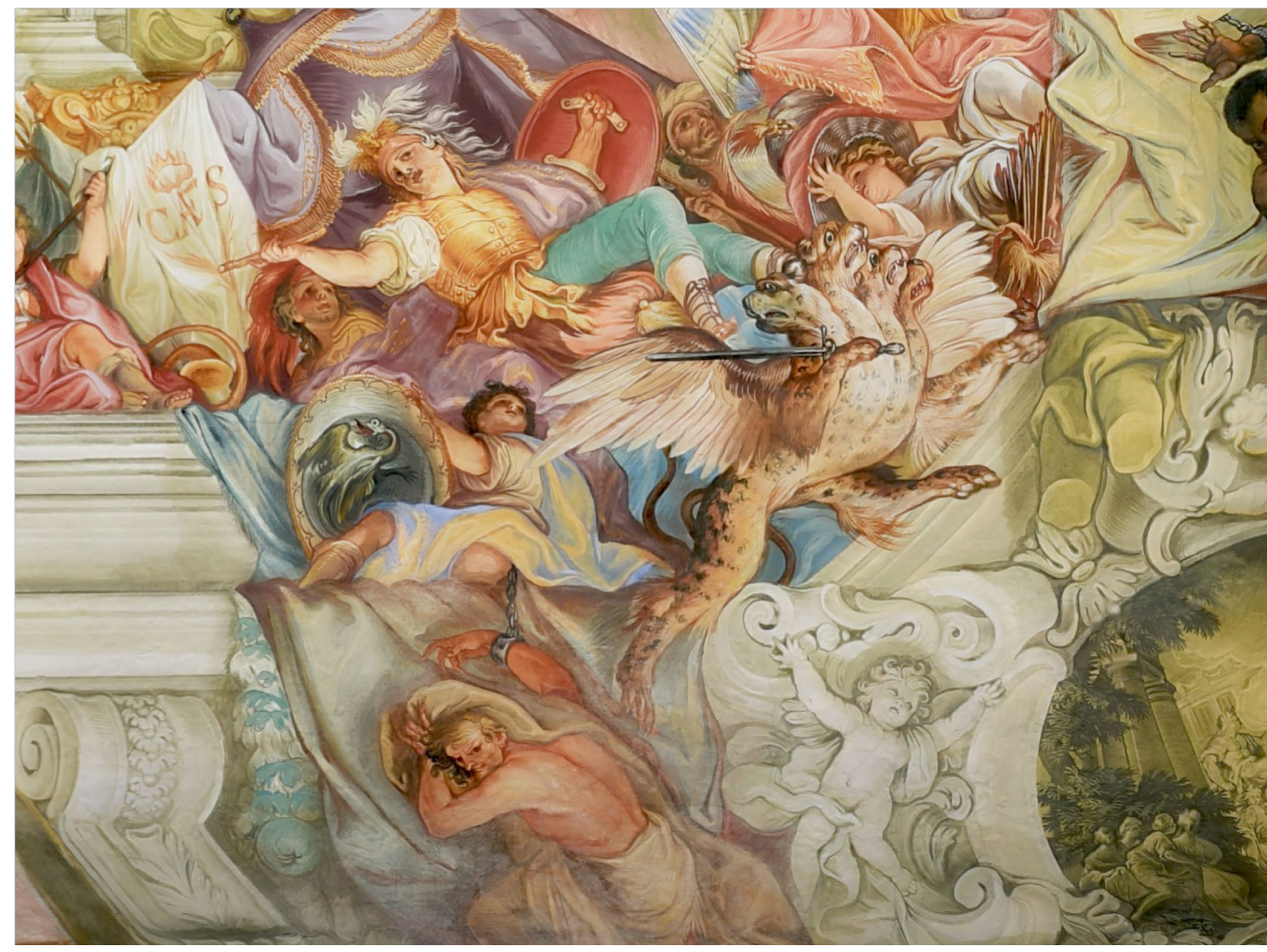

Abb. 12: Detailansicht des Texture Mappings. Ein Vergleich mit Abb. 04 offenbart eine deutlich erhöhte Auflösungsfähigkeit der Textur, welche durch das Texture Mapping erreicht werden kann. (Max Rahrig). 
Die gleichen Modelle lassen sich auch in VR-Anwendungen importieren und anschließend mit VRBrillen erkunden. Wissenschaftler können die Räume auf diese Weise digital aus jeder nur erdenklichen Perspektive betrachten und die Malereien analysieren. Dies birgt besondere Vorteile bei der Betrachtung und Analyse von nur schwer zugänglichen Objekten. Auch für die Vermittlung an Touristen und interessierte Besucher lassen sich die Räume auf diese Weise virtuell erlebbar machen. Für eine Präsentation im Museum oder im Internet können in Programmen wie 3DStudiomax ${ }^{\odot}$, Blender ${ }^{201}$ oder Cinema $4 \mathrm{D}^{\odot}$ zudem virtuelle Rundgänge animiert und Videos generiert werden (Abb. 13).

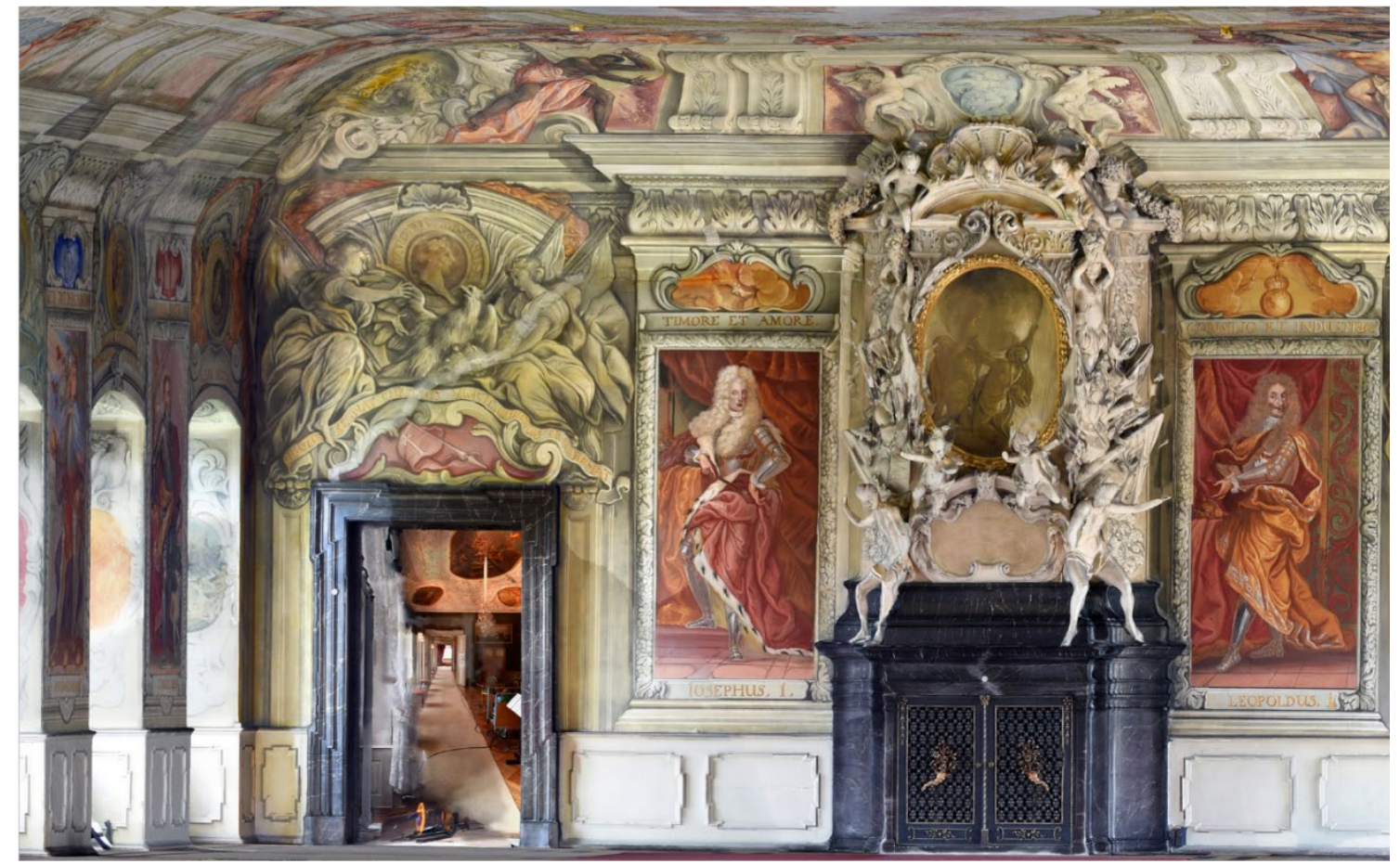

Abb. 13: Ansicht des 3D-Modells des Bamberger Kaisersaals (Max Rahrig).

Zusätzlich zur Darstellung des farbigen Oberflächenmodells kann zudem die Textur ausgeblendet werden, sodass im 3D-Modell die reine Oberflächentopografie angezeigt wird (Abb. 14). Diese Darstellung spiegelt im Falle des Bamberger Kaisersaals den Zustand des Saals vor 1707 wider, bevor Melchior Steidl mit der Ausmalung begann. ${ }^{202}$ Für eine möglichst authentische Darstellung dieses Vorzustands wurden die beiden Kamine aus dem 3D-Modell entfernt, da auch diese erst nach 1707 errichtet wurden. ${ }^{203}$ Zudem werden in dieser Ansicht weitere Informationen sichtbar gemacht, die sonst unter der ausgeführten Malerei verborgen bleiben wie der Verlauf der Deckenbalken oder der Gewölbeansatz im Übergang von Wand- zu Deckenflächen. Beides sind wichtige konstruktive Details, die bei einer Betrachtung des realen Raums nicht oder nur schwer wahrzunehmen sind.

\footnotetext{
${ }^{201}$ Siehe https://www.blender.org (GNU: General Public License).

202 Erichsen et al. 2007, S. $215 \mathrm{ff}$.

${ }^{203}$ Vgl. Dümler 2001, S. $175 f$ und Erichsen 2007, S. 36.
} 


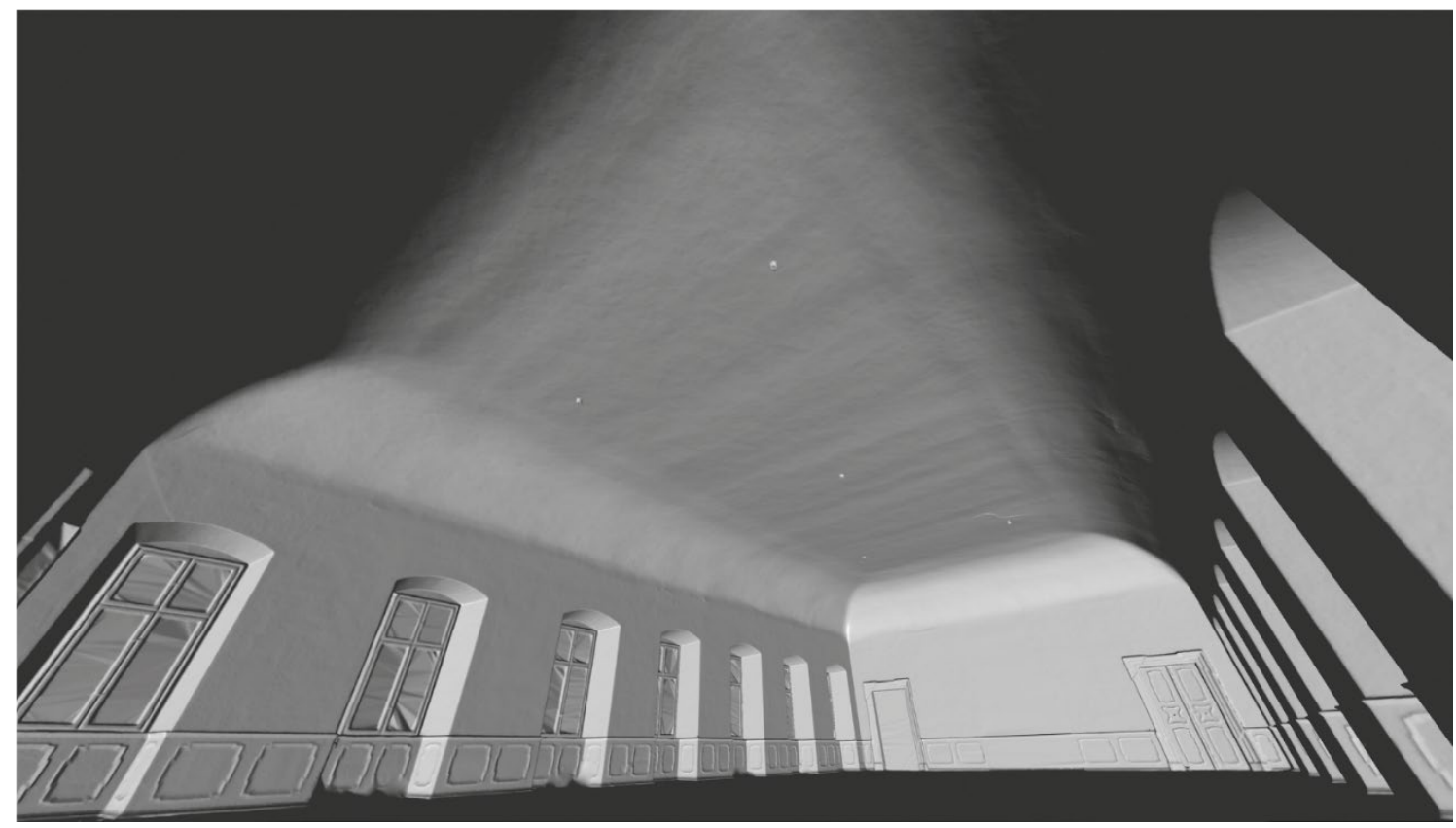

Abb. 14: Ansicht des 3D-Modells des Bamberger Kaisersaals im Zustand bevor mit der Ausmalung der Decke begonnen wurde, vor 1707 (Max Rahrig).

In einem zweiten Modell wurde lediglich die Decke des Kaisersaals texturiert (Abb. 15). ${ }^{204}$ Dieses Modell spiegelt den Zustand um 1707 wider, als Steidl die Ausmalung der Decke abgeschlossen, jedoch noch nicht den Auftrag für die Ausmalung der Wandflächen übernommen hatte. ${ }^{205}$ Die vergleichende Betrachtung der unterschiedlich texturierten 3D-Modelle mittels Virtual Reality ermöglicht den Wissenschaftlern nun erstmals, den Eindruck des Kaisersaals vor Beginn der Wandausmalung und in den Zwischenstadien zu untersuchen. Auf diese Weise können neue Erkenntnisse über die Planungsphase der Malereien oder den Arbeitsablauf des Malers Steidl bei der Ausgestaltung des Kaisersaals gewonnen werden.

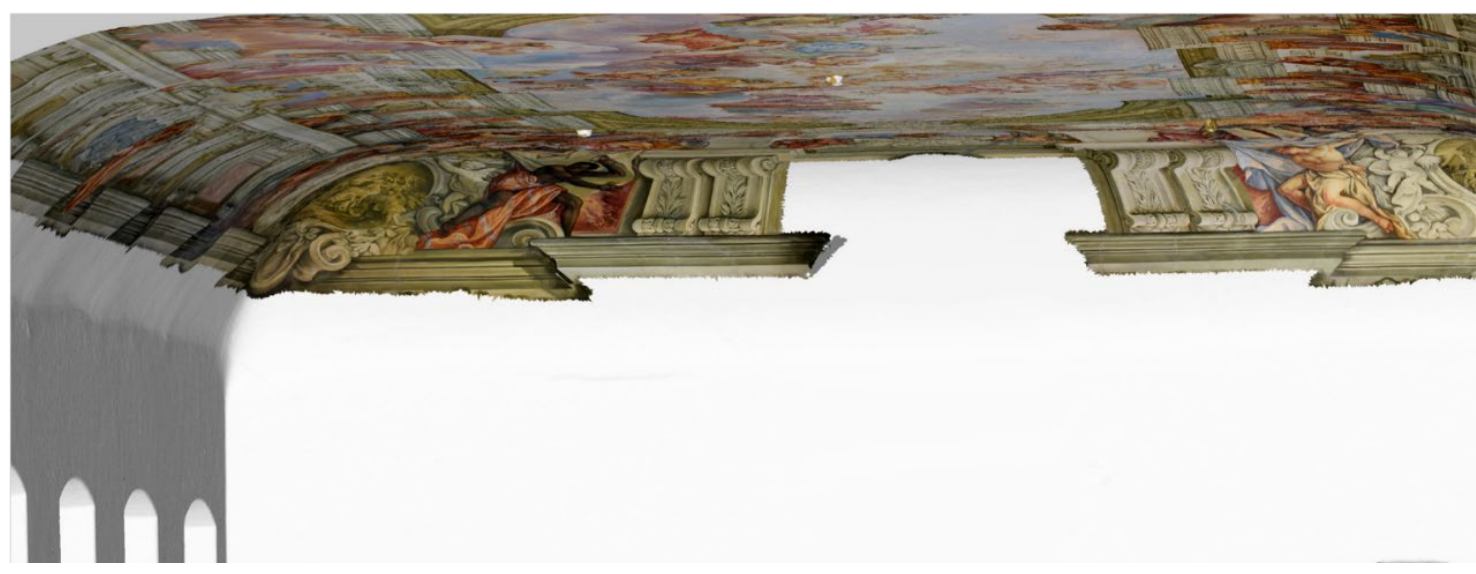

Abb. 15: Ansicht des 3D-Modells im Zustand nach Fertigstellung des Deckengemäldes um 1707 / 08 (Max Rahrig).

\footnotetext{
${ }^{204}$ Auch in diesem Modell wurden zur Steigerung der Authentizität die beiden Kamine aus dem 3D-Modell entfernt. Vgl. Dümler 2001, S. $175 f$ und Erichsen 2007, S. 36.

${ }^{205}$ Erichsen et al. 2007, S. $215 \mathrm{ff}$.
} 


\section{Arbeitsaufwand}

Die Datenaufnahme erfolgte im Juni 2016 innerhalb von drei Tagen. In dieser Zeit wurde nicht nur der Kaisersaal, sondern noch weitere Räume der Neuen Residenz in Bamberg dreidimensional dokumentiert (Abb. 16). Die Dokumentation umfasste zusätzlich das Audienzzimmer im 2. Obergeschoss, welches eben falls zum kaiserlichen Appartement zählte, zudem wurde das kurfürstliche Schlafzimmer aufgenommen. Im 1. Obergeschoss wurden darüber hinaus der äußere und innere Vorsaal sowie der Speisesaal als zusammenhängende Raumabfolge des fürstbischöflichen Appartements erfasst. ${ }^{206}$

Das Erstellen des hochauflösenden Oberflächenmodells des Kaisersaals dauerte etwa 2,5 Tage, wobei die automatisierten Rechenprozesse die meiste Zeit in Anspruch nahm. Die aktive Arbeitszeit für die Triangulation, das Schließen von Löchern, Entfernen der Bestuhlung und die generelle Optimierung des 3D-Modells lag bei etwa 8 Stunden. Das Ausrichten und Maskieren von Einzelbildern für die Berechnung des Texture Mappings in Variante 1 dauerte durchschnittlich etwa 30 Minuten pro Aufnahme, sofern ausreichend markante Bereiche für die Ausrichtung vorhanden waren. Im Falle des Kaisersaals dauerte dieser Arbeitsschritt jedoch deutlich länger, da in dem vollständig ausgemalten Raum außer den Fensternischen und Kaminen kaum eindeutig dreidimensional zu identifizierende Bereiche in der Geometrie fassbar waren, was die Ausrichtung der Fotografien für die Deckenbereiche deutlich erschwerte. Räume mit Wandvertäfelungen und Stuckdecken weisen dagegen eine deutlich plastischere Oberflächentopografie auf, wodurch die Orientierung der Fotos wesentlich schneller erfolgen kann. Die Vorausrichtung der Einzelaufnahmen durch die Scanner-Software half jedoch, diese Zeit deutlich zu reduzieren. Die Berechnung der Textur erfolgte anschließend mit einer Auswahl von etwa 20 Fotografien.

In Variante 2 dauerte die Ausrichtung der verwendeten 130 Einzelbilder ca. zwei Stunden. Aufgrund von deutlichen Farbunterschieden zwischen den Fotografien, die durch die Aufnahmesituation bei Tageslicht bedingt waren, mussten jedoch auch hier die Einzelbilder nach der Ausrichtung maskiert und selektiert werden. Beide Varianten hatten folglich einen vergleichbaren Zeitaufwand von ca. 24 Stunden.

Durchschnittlich kann ein Zeitbedarf von etwa fünf Arbeitstagen für die Aufnahme und Aufbereitung bis zum vollständig texturierten 3D-Oberflächenmodell eines Raums postuliert werden. Stark verwinkelte Räume wie bspw. Treppenaufgänge oder Arkadengänge, aber auch äußere Faktoren wie Mobiliar, Lichtverhältnisse, Zugänglichkeit des Raums und die Erfahrung des Bearbeiters können den benötigten Zeitaufwand deutlich beeinflussen.

\footnotetext{
${ }^{206}$ Vgl. Spicale 2016.
} 


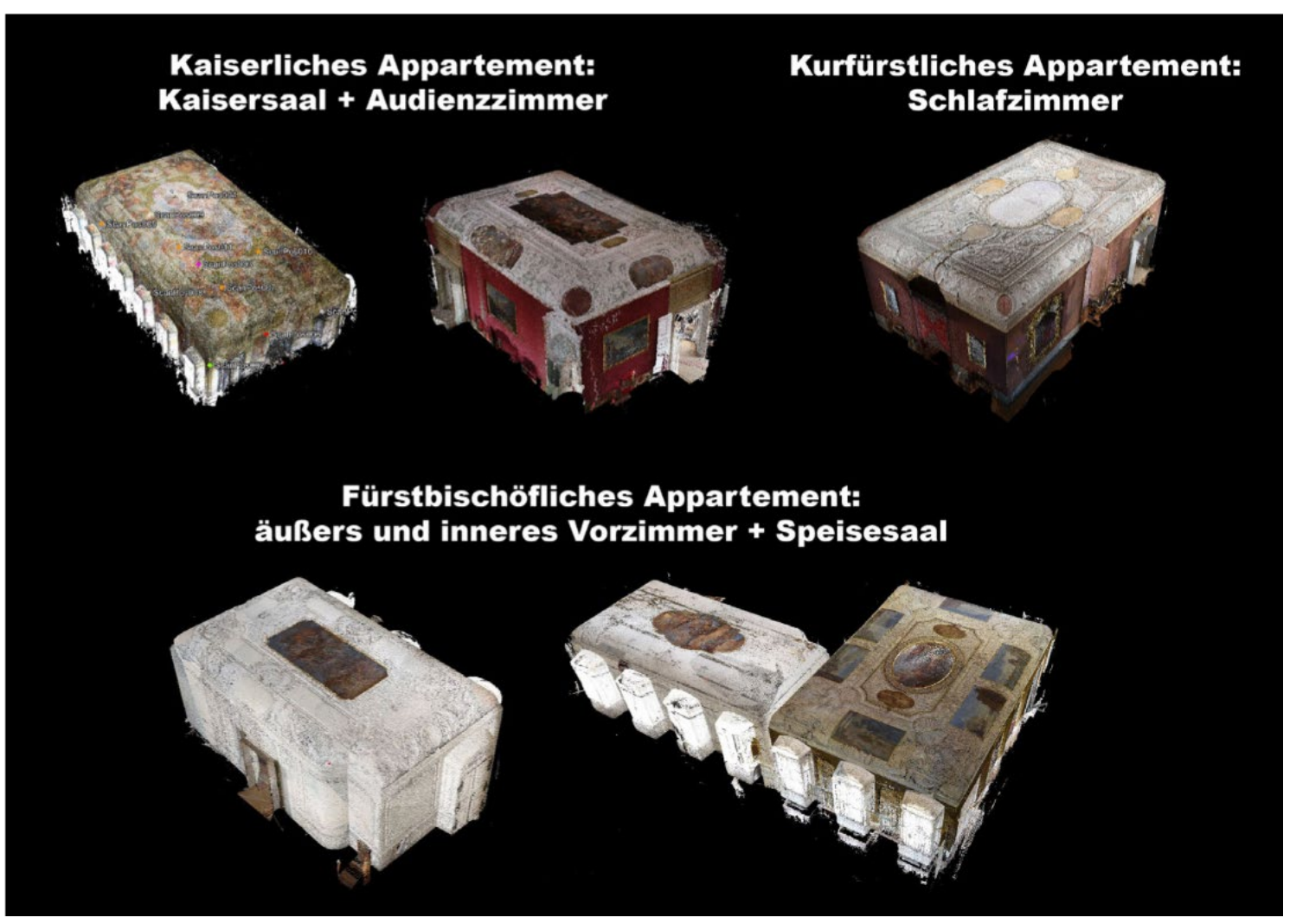

Abb. 16: Überblick der bisher vom KDWT digitalisierten Räume der Neuen Residenz in Bamberg (Max Rahrig).

\section{Ausblick}

Über eine farbgetreue, hochauflösende Oberflächendokumentation hinaus bieten die beschriebenen Varianten des Texture Mappings noch weitere Möglichkeiten zur umfassenden Analyse historischer Räume. So lassen sich neben den verwendeten Farbfotos auch UV-, IR- oder Thermografie-Bilder für die Texturierung eines 3D-Modells - oder einzelner Teilbereiche - heranziehen. Diese multispektralen 3D-Modelle würden eine zusätzliche Informationstiefe für Oberflächenanalysen, Befund- und Schadenskartierungen sowie die Untersuchung von Konstruktion und Statik liefern. ${ }^{207}$

\footnotetext{
${ }^{207}$ Erica Nocerino, Dirk H. Rieke-Zapp, Elisabeth Trinkl, Ralph Rosenbauer, Elisa Mariarosaria Farella, Daniele Morabito, Fabio Remondino, Mapping VIS and UVL Imagery on 3D Geometry for Non-Invasive, Non-Contact Analysis of a Vase, in: Int. Arch. Photogramm. Remote Sens. Spatial Inf. Sci., XLII-2, 2018, S. 773-780; Max Rahrig, Rainer Drewello, Andrea Lazzeri, Opto-Technical Monitoring - A Standardized Methodology to Assess the Treatment of Historical Stone Sur faces, in: Int. Arch. Photogramm. Remote Sens. Spatial Inf. Sci., XLII-2, 2018, S. 945-952; Talal Akasheh, José Luis Lerma, Miriam Cabrelles, Naif Adel Haddad, The multispectral and 3D study of the Obelisk Tomb in Petra, Jordan, in: Marinos loannides, Dieter Fellner, Andreas Georgopoulos, Diofantos Hadjimitsis (Hg.), 3rd International Conference dedicated on Digital Heritage. Short Papers, Limassol, Cyprus, 2010, S. 35-40; Miriam Cabrelles, S. Galcerá, Santiago NavarroJosé Luis Lerma, Talal Akasheh, Naif Haddad, Integration of 3D laser scanning, photogrammetry and thermography to record architectural monuments, in: 22nd CIPA Symposium, Kyoto, 11-15 October, Japan, 2009 und Zalama et al. 2011.
} 
Fazit

Mit vergleichsweise geringem Aufwand lassen sich mit der oben beschriebenen Methode 3D-Modelle erstellen (Abb. 17), die sowohl von Architekten und Restauratoren als Arbeitsgrundlage verwendet, aber auch von Kunsthistorikern, Wahrnehmungspsychologen oder von Museumspädagogen zur Erkundung, Vermittlung und Analyse von Räumen oder ganzen Raumabfolgen genutzt werden können. Es kann jedoch nicht pauschal gesagt werden, welche Variante zur Erstellung eines texturierten 3DModells die » richtige « ist. Wie eingangs erläutert, gibt es neben den beschriebenen Varianten noch weitaus mehr Möglichkeiten, um vergleichbare Ergebnisse zu erzielen. Die beiden beschriebenen Varianten können demnach als - in der Praxis bewährte - Vorschläge für die Erstellung hochauflösender Texture Mappings dienen, basierend auf einzelnen Fotos (Variante 1) oder ganzen Bildserien (Variante 2). Welche Methode zur Erstellung der 3D-Dokumentation letztlich verwendet werden soll, ist von diversen Parametern abhängig. Hierunter fallen die Fragestellungen und Anforderungen an das Ergebnis, aber auch die Beschaffenheit des zu dokumentierenden Objektes oder Raums an sich. Soll oder muss der Raum bspw. mit seinem gesamten Mobiliar und sonstiger beweglicher Ausstattung erfasst werden und dieses auch im 3D-Model dargestellt werden oder kann der Raum vorab ausgeräumt werden, um lediglich die Raumhülle dokumentieren zu können? Vor Beginn der Dokumentation sollte demnach exakt geplant werden, welche Ergebnisse erzielt werden sollen und welche äußeren Faktoren auf die Datenaufnahme einwirken können, um die richtige Herangehensweise zu wählen. ${ }^{208}$

\footnotetext{
${ }^{208}$ Fabio Menna, Erica Nocerino, Fabio Remondino, Matteo Dellepiane, Marco Callieri, Roberto Scopigno, 3D Digitization of an Heritage Masterpiece - A Critical Analysis on Quality Assessment, in: Int. Arch. Photogramm. Remote Sens. Spatial Inf. Sci., XLI-B5, 2016, S. 675-683; Fabio Remondino, Alessandro Rizzi, Reality-based 3D documentation of natural and cultural heritage sites - techniques, problems, and examples, in: Appl Geomat 2010 (2), S. 85-100.
} 


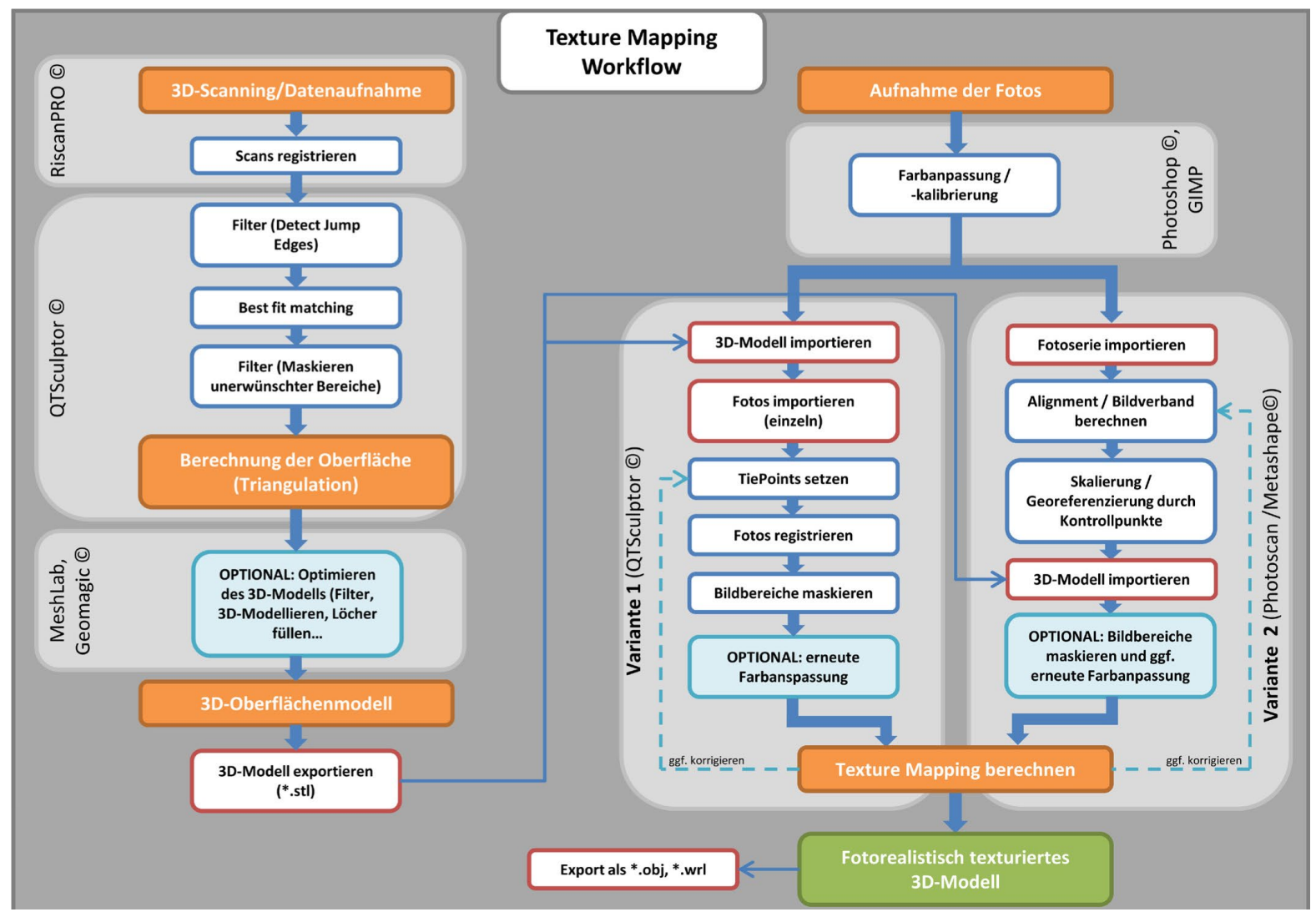

Abb. 17: Schematische Darstellung des Workflows zur Erstellung eines Texture Mappings. 


\section{Hochauflösende 3D-Oberflächenvergleiche}

Besonders in den archäologischen Wissenschaften sowie der musealen Forschung und Präsentation hat sich der Einsatz moderner, berührungsfreier 3D-Dokumentationsmethoden in den letzten Jahren gut etabliert. Aus den Datensätzen werden untere anderem 2D-Ansichten für Fundkataloge erstellt, die somit eine möglichst objektive und interpretationsfreie Darstellung der Fundstücke aufweisen. Darüber hinaus digitalisieren große Museen ihre Sammlungen und stellen sie für alle interessierten Betrachter*innen frei zugänglich auf Internetplattformen wie Sketchfab zur Verfügung. Für die Erstellung der 3D-Modelle von Objekten aus Sammlungen und archäologischen Grabungen können dabei die gleichen Arbeitsschritte wie für die Dokumentation komplexer Großobjekte verwendete werden. Es muss jedoch gezielt die passende Technik für die Generierung der Daten gewählt werden, um die erforderliche Genauigkeit und Detailschärfe zu gewährleisten. Es bietet sich für die Digitalisierung von Sammlungsobjekten daher der Einsatz von handgeführten Laserscannern, IBM oder SLS an.

Die hochauflösenden Datensätze bieten, über die Erstellung von Ansichten, Plänen und Visualisierungen hinaus, wesentlich weiterreichende Einsatzmöglichkeiten für eine wissenschaftliche Bearbeitung des Kulturguts. So können mit dem Einsatz von SLS Oberflächen in einer mikroskopischen Genauigkeit von bis zu wenigen $\mu \mathrm{m}$ Punktabstand erfasst werden. Aufgrund der Erfassung und Auswertung feinster Bearbeitungsspuren ermöglicht dies das Treffen von Aussagen zu Herstellungsprozessen. Die bisher in der Kulturerbeforschung nie ernsthaft genutzte, direkte, dreidimensionale Inspektion von Volumina und Oberflächenbeschaffenheit zwischen digitalen Derivaten bietet dabei die objektübergreifende Möglichkeit einer vergleichenden Analyse der Datensätzen. Der Nutzen und die Grenzen dieses innovativen Analysewerkzeugs werden nachfolgend für ihren Einsatz in den Fachbereichen der Kunstgeschichte und Restaurierungswissenschaft vertiefend dargelegt.

\subsection{D-Vergleiche für kunstwissenschaftliche Serienanalysen}

2014 konnten in der Galerie Peter Freeman, Inc. in New York zehn Ausführungen der Skulptur Bambino ebreo (jüdisches Kind) von Medardo Rosso (1858-1928) ausgestellt werden. Einige Varianten stammen aus privaten Sammlungen und wurden zuvor nie der Öffentlichkeit präsentiert. Initiiert von Dr. Sharon Hecker erfolgte im Kontext der Ausstellung ein zweitägiger Expertenworkshop für eine eingehende Untersuchung der Skulpturen. Hierbei wurden die Exponate von Ronald E. Street, Senior Manager of 3D Image, Molding, and Prototyping, Merchandise and Retail Department, des Metropolitan Museum of Art, New York (MET) mittels Structured-Light-Scanning hochauflösend dokumentiert. ${ }^{209}$ Ziel der zerstörungsfreien und berührungslosen Digitalisierung der Oberflächen waren innovative

\footnotetext{
${ }^{209}$ Vgl.<https://www.italianmodernart.org/2014-bambino-ebreo-qa/> letzter Zugriff 07.08.2019.
} 
vergleichende Untersuchungen zu den Fertigungsprozessen und der Arbeitsweise des Künstlers. Hierzu wurden erstmals virtuelle 3D-Vergleiche in Serie produzierter Skulpturen angefertigt. Anhand der 3DVergleiche können selbst kleinste Abweichungen zwischen den Skulpturen erfasst und dargestellt werden. Auf diese Weise konnten Cluster von Skulpturen, die aus identischen Formen stammen, gebildet werden. Es konnten aber auch neue Hinweise für den Schaffensprozess Rossos und der nachträglichen Überarbeitung der Skulpturen durch diesen erarbeitet werden. Darüber hinaus ließ sich eine Skulptur als Ur-Modell identifizieren, welches von Rosso als Grundlage für die Erstellung von Gussformen für die Serienproduktion verwendet wurde. Leider verstarb Ronald Street vor der Vollendung der Arbeiten, sodass die Erstellung der 3D-Vergleiche und ihre weitere Auswertung vom Verfasser durchgeführt wurde. 


\section{Publikation 3: Rethinking Uniformity: Analysis of Rosso's Serial Forms of the Bambino ebreo through Digital Surface Comparison (Rahrig/Street 2019)}

Der Artikel ist hier als Post-Print in einem angepassten Layout wiedergegeben. Für eine korrekte Zitierweise und Seitenzahlen bitte die Originalquelle verwenden:

Rahrig, M. / Street, R.: „Rethinking Uniformity: Analysis of Rosso's Serial Casts of the Bambino ebreo through Digital Surface Comparison." In: Hecker, S. (Hg.): Finding Lost Wax: the Disappearance and Recovery of an Ancient Casting Technique and the Experiments of Medardo Rosso, Brill Publishing, Studies in Art and Materiality, Vol. 3, S. 275-302, Doi: https://doi.org/10.1163/9789004439931.

(chapter in a peer reviewed Book)

\section{Introduction}

To gain better knowledge of Rosso's production technology and an understanding of his working methods, 3D documentation of twelve variants of the Bambino ebreo was carried out to enable highresolution surface comparisons. This technology originates from mechanical manufacturing, where it is used as a tool for quality control. In this research it is applied to art objects produced in series.

Rosso's Bambino ebreo casts are excellent objects for this study. From 1892/93 onwards, during his time in Paris, he created many versions of the sculpture in different materials. Most of the Bambino ebreo casts are wax, but there are also bronze casts and plaster versions preserved. ${ }^{210} \mathrm{It}$ is known that Rosso used gelatin molds for his serial production, but these are not easily reusable. ${ }^{211}$ After a few copies, a gelatin mold will deteriorate and lose its detail and sharpness. ${ }^{212} \mathrm{It}$ is obvious, therefore, that Rosso needed more than a single gelatin mold for casting his Bambino ebreo casts. For this reason, the following study will compare similarities between the sculptures and identify differences in order to gain new evidence for his way of working. The following variants of the Bambino ebreo are included in this study: the Ex-Monti, Nasher, Timken, Sussex, Ex-Brunauer, Ex-Pawlowski, and Ex-Meek waxes, the Cologne, Folkwang, Ex-Bergamo, and Kröller-Müller bronzes, and a Bambino ebreo called Black Plaster (fig. 13.1). ${ }^{213}$

\footnotetext{
${ }^{210}$ Sharon Hecker, A Moment's Monument: Medardo Rosso and the International Origins of Modern Sculpture (Berkeley: University of California Press, 2017), 132-33.

${ }^{211}$ Derek Pullen, “Gelatin Molds: Rosso's Open Secret," in Medardo Rosso: Second Impressions, ed. Harry Cooper and Sharon Hecker (New Haven, CT: Yale University Press, 2003), 96-102.

${ }^{212}$ A Ifred Bohnagen, Der Stukkateur und Gipser (Munich: Callway, 1987), 129-30. First published in Leipzig, 1914.

${ }^{213}$ The 3D scans were made by Ron Street. He also started a first processing of the data. The two sections, "Methodological Approach" and "Exploration of the Metrology," are based on his script. Unfortunately, he passed away before he could finish his work.
} 


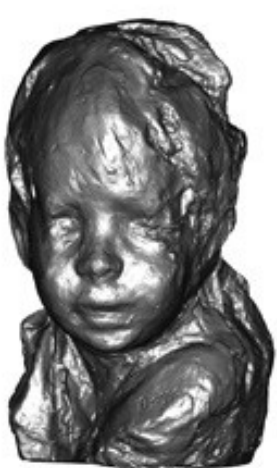

Ex-Monti wax

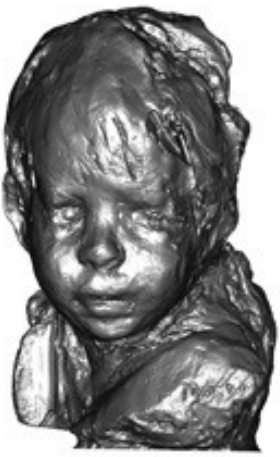

Sussex wax

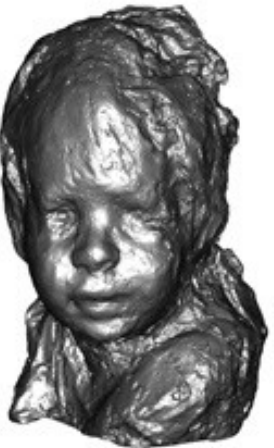

Cologne bronze

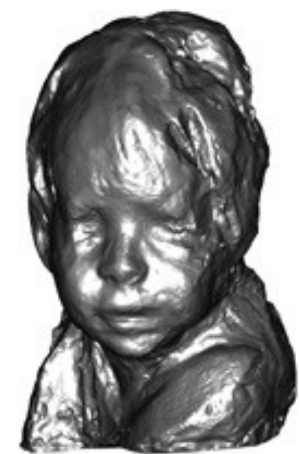

\section{Ex-Meek wax}

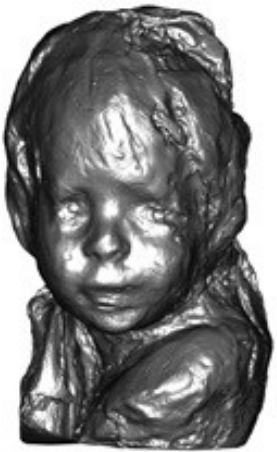

Timken wax

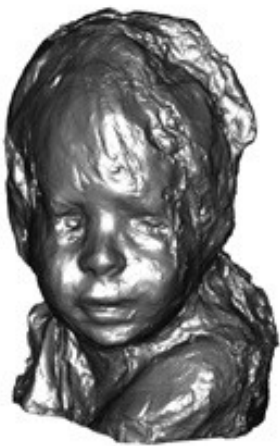

Ex-Bergamo bronze

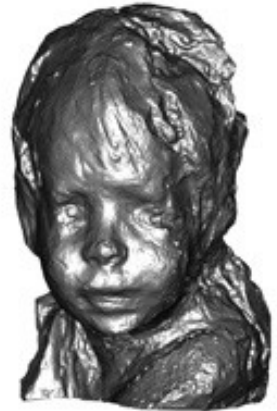

Nasher wax

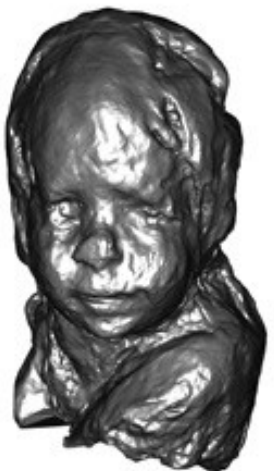

Ex-Brunauer wax

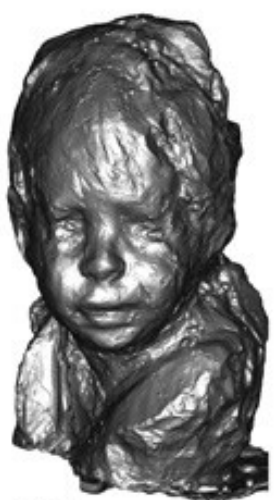

Folkwang bronze

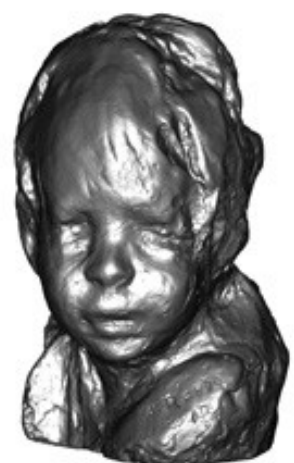

Ex-Pawlowski wax

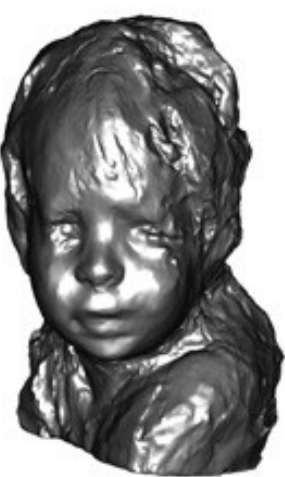

Black Plaster

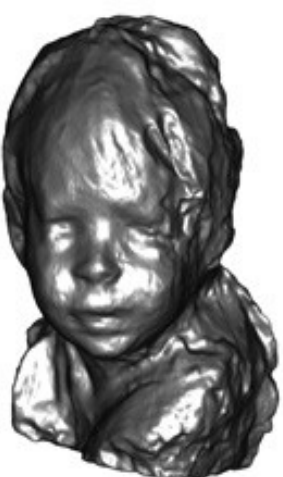

Kröller-Müller bronze

Figure 13.1 Overview of the twelve scanned Bambino ebreos (c) Max Rahrig

\section{Methodological Approach}

To undertake these metrology studies, which are often referred to in industry as "deviation studies," the geometry of each Bambino ebreo was captured with a Breuckmann smartSCAN structured light scanner (SLS). ${ }^{214}$ The captured 3D datasets, which define the geometry of the sculptures, are then compared in order to determine how one sculpture differs from the other. The industrial technique of comparing CAD models to scanned as-built parts, also known as "first-part inspections," has been developed over the last twenty years as both the accuracy of 3D imaging devices and computational

\footnotetext{
${ }^{214}$ Now called the Aicon SmartScan. See https://www.hexagonmi.com/products/white-light -scannersystems/aicon-smartscan
} 
power have increased significantly. Deviation studies are now a standard method of assuring that prototypes and as-built parts meet the specifications of the CAD drawings on which they are based. ${ }^{215}$

Deviation studies have been adopted by the cultural heritage, conservation, and science communities to better understand the relationship between objects of similar size and appearance. The first to use 3D comparisons for art history was Hans de Roos for the comparisons of different bronze sculptures of Rodin's The Thinker in 2003 and 2004. ${ }^{216}$ Tonny Beentjes, Ronald Street, David Thurrowgood and François Blanchetière supplemented this study in 2013. ${ }^{217}$ For example, other studies focused on Rodin's The Burghers of Calais and Matisse's Reclining Nude I (Aurora). ${ }^{218}$ This method can reveal important differences between objects previously unobtainable with standard measuring techniques. The method is also used for the monitoring of conservation measures and deterioration studies in heritage conservation. ${ }^{219}$

An SLS such as the Breuckmann SmartScan is a scanning device for measuring the 3D shape of an object using projected light patterns and a camera system. ${ }^{220}$ Projecting a narrow band of light onto a threedimensionally shaped surface produces a line of illumination that appears distorted when viewed from perspectives other than that of the projector, and this distortion can be used for an exact geometric reconstruction of the surface shape. ${ }^{221}$

Rosso's Bambino ebreo casts posed a unique set of problems for this method of 3D surface capture. Black or dark surfaces, as well as surfaces that are translucent and reflective, are extremely difficult to scan. The wax sculptures are both translucent and reflective, the bronzes are almost black, and one sculpture, a blackish wax, is all three. Therefore all sculptures required extensive testing, and the system's settings and parameters needed constant adjustment to achieve optimal results. One would

\footnotetext{
${ }^{215}$ See Timothy S. Newman and Anil K. Jain, "A System for 3D CAD-based Inspection Using Range Images," Pattern Recognition 28, no. 10 (1995): 1555-74, DOI: 10.1016/0031 -3203(95)00028-X; Lie Yadong and Gu Peihua, "Automatic Localization and Comparison for Free-Form Surface Inspection," Journal of Manufacturing Systems 25, no. 4 (2006): 251-68, DOI: 10.1016/S0278-6125(08)00007-1. ${ }^{216}$ Hans De Roos, "The Digital Sculpture Project: Applying 3D Scanning Techniques for the Morphological Comparison of Sculptures," Computer and Information Science 9, no. 2 (2004): 69-74.

217 Tonny P. C. Beentjes, Ronald E. Street, David Thurrowgood and François Blanchetière, "3-D imaging as a research tool for the study of bronze sculpture," METAL 2013: Interim Meeting of the ICOM-CC Metal Working Group, Conference Proceedings, 16-20 September 2013, ed. Ewan Hyslop, Vanesa Gonzalez, Lore Troalen and Lyn Wilson (2013): paper 25.

${ }^{218}$ Daisuke Miyazaki, Mawo Kamakura, Tomoaki Higo, Yasuhide Okamoto, Rei Kawakami, Takaaki Shiratori, Akifumi Ikari, Shintaro Ono, Yoshihiro Sato, Mina Oya, Masayuki Tanaka, Katsushi Ikeuchi, and Masanori Aoyagi, "3D Digital Archive of the Burghers of Calais," 12th international conference on Interactive Technologies and Sociotechnical Systems, VSMM (Virtual Systems and Multimedia) (2006): 399-407. Ann Boulton, "Altered states: Henri Matisse's sculpture Aurora," AIC Objects Specialty Group postprints, Vol. 14, (2007): 110-129. ${ }^{219}$ Max Rahrig, Rainer Drewello and Andrea Lazzeri, "Opto-Technical Monitoring: A Standardized Methodology to Assess the Treatment of Historical Stone Surfaces," International Archives of Photogrammetry, Remote Sensing and Spatial Information Sciences 42-2 (2018): 945-52, DOI: 10.5194/isprs-archives-XLII-2-945-2018 ${ }^{220}$ Borko Furht, Encyclopedia of Multimedia, 2nd ed. (New York: Springer, 2008), 222.

${ }^{221}$ Rahrig, Drewello and Lazzeri, “Opto-Technical Monitoring," 945-46.
} 
perhaps have assumed that the settings would have been interchangeable across similar objects, for example, the yellowish wax sculptures, but each individual sculpture required substantially different settings to optimize the scan results.

A completed digital model of a Bambino ebreo is composed of between sixty and ninety individual scans. These are aligned into a set of 3D data points called a point cloud. Each point is assigned a corresponding $\mathrm{X}-\mathrm{Y}-\mathrm{Z}$ coordinate. The point cloud is then processed to create a closed polygon mesh. For the Bambino ebreo casts, the surface models are comprised of over ten million tiny polygons.

\section{Exploration of the Metrology}

A comparison of the sculptures' dimensions, as exemplified by their volumes, can give a first, rough indication of their similarities and differences. In order to calculate the volume of the objects it was necessary to remove any scanned parts of the bases and close the resulting holes. Some of the sculptures are solid and filled with plaster, while others, especially the casts, have a certain material thickness of bronze, but are mostly hollow. This process therefore provides only a relative approximation of the true volume, but it does offer a good place to begin to understand the geometric differences between the sculptures. For example, the Ex-Meek Wax has the greatest volume and the Cologne Bronze the least. On the other hand, some of the wax sculptures have added plaster at the bottom to change their orientation and angle of view, which also causes differences in volume.

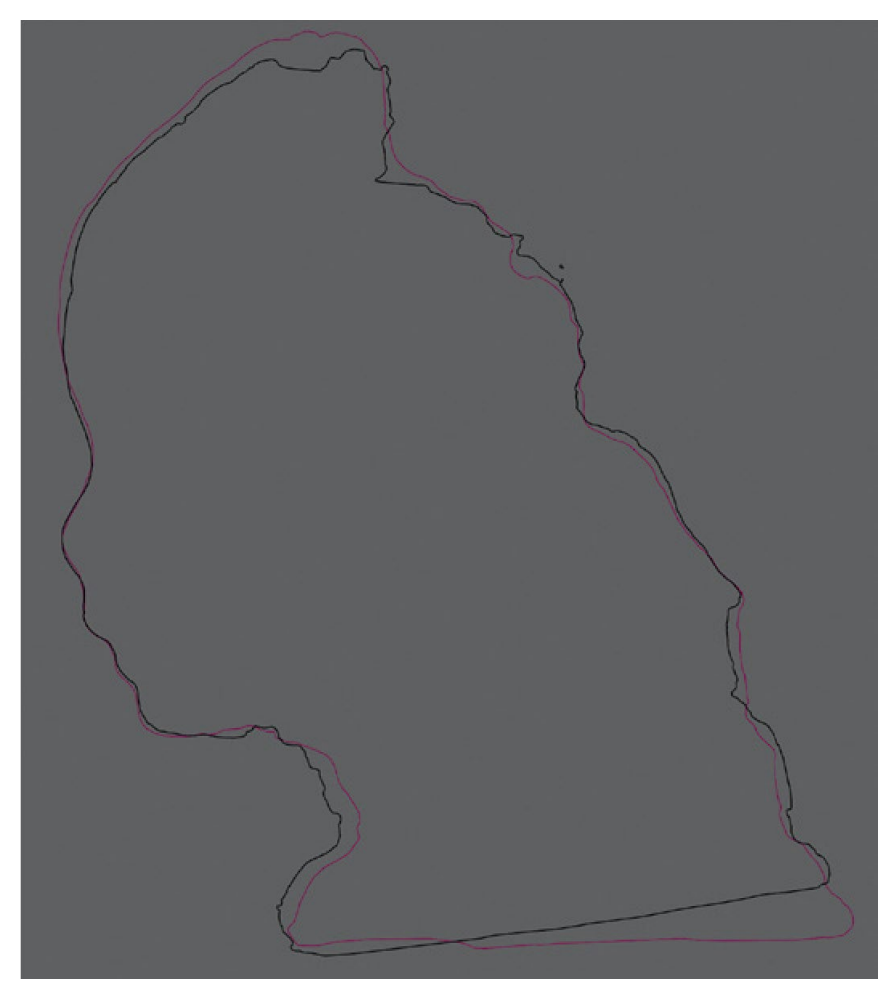

Figure 13.2 Comparison of cross-sections through Ex-Meek Wax (red line) and Cologne Bronze (black) @ Ronald Street 
Better results come from a comparison of the surface topography of the sculptures. To compare two models, a combination of best-fitting algorithms and manual alignments was deployed to position one object onto the other. One of the techniques used is to cut sections through the aligned models to see how well they are aligned, and how far they differ from each other. In the case of the Ex-Meek Wax and the Cologne Bronze, one can see graphically how close the two objects are in profile (fig. 13.2). The perplexing problems associated with the Rosso sculptures are also visible here: while the sculptures have, to a certain extent, very similar underlying structures, the surfaces are somewhat different. As can be seen in the profiles, the surfaces are not identical and diverge in many areas of the profile sections.

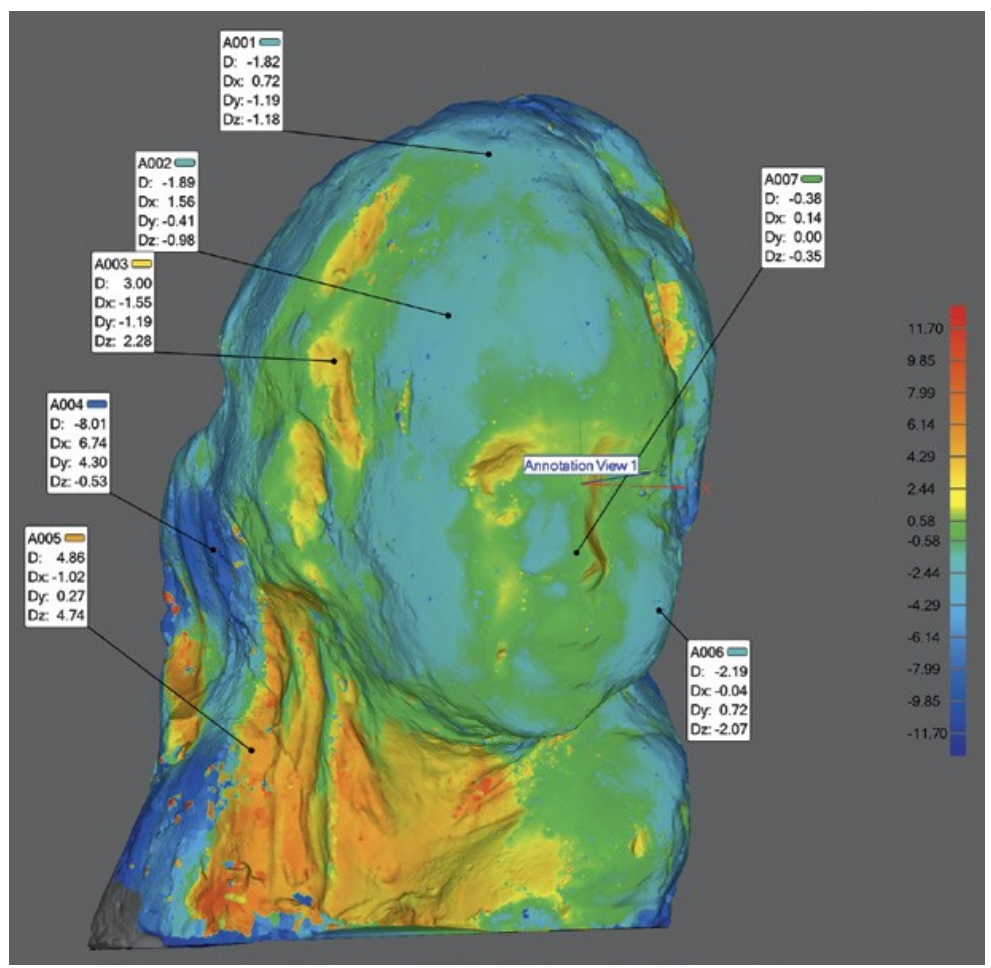

Figure 13.3 Quantified 3D comparison of the two sculptures (C) Ronald Street

The deviations between the objects can be further quantified by creating false color images, where the color represents the distance between one surface and the other (fig. 13.3). Profile sections can also be quantified with this method. Annotations show accurately at any location how one model deviates from the other. The 3D deviations for this model show on average a maximum of $+2.62 /-2.74$ $\mathrm{mm}$, a standard deviation ${ }^{222}$ of $3.4 \mathrm{~mm}$, and a root mean square ${ }^{223}$ of $3.5 \mathrm{~mm}$. Deviation distributions can also be calculated (fig. 13.4). For this model, $74 \%$ of the deviation distribution is within a +/- range of $2 \mathrm{~mm}$, meaning that $74 \%$ of the surfaces deviate no more than $4 \mathrm{~mm}$ in any one place. ${ }^{224}$

\footnotetext{
${ }^{222}$ Standard deviation is quantity calculated to indicate the extent of deviation for a group as a whole.

${ }^{223}$ Root mean square is a statistical measure of the magnitude of a varying quantity. It is especially useful when variates are positive and negative.

${ }^{224}$ Surface comparisons were processed by using Geomagic Qualify software.
} 


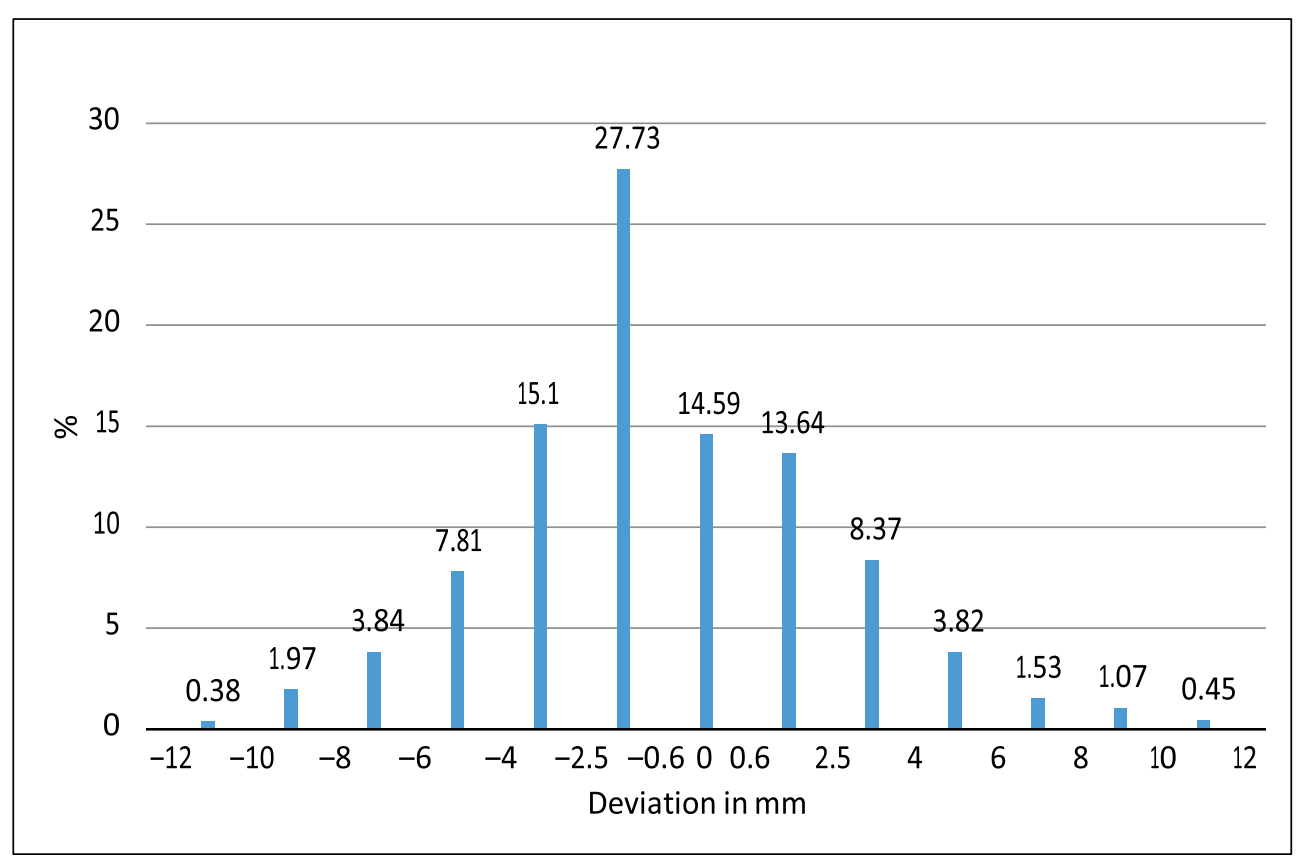

Figure 13.4 Deviation distribution. Calculation based on the surface comparison of Fig. 13.2 (C) Ronald Street

One of the noteworthy observations is that the profiles made vertically through the front of the face seemed to correspond very well from the forehead to the bottom of the chin (fig. 13.5). Starting with the Ex-Meek Wax and the Timken Wax, one can immediately see the similarities and differences between the two sculptures. The fronts of the faces are almost perfectly aligned, and although the Timken sculpture is somewhat smaller front to back, the profiles of the back side of the sculptures are almost identical. When the Sussex Wax is added to the group, one again sees that the front profiles, particularly the Sussex and Timken waxes, are almost indistinguishable. Yet the almost perfect alignment of the front portion of the sculptures is not continued throughout: the shoulder of the Sussex Wax protrudes far beyond those of the Ex-Meek and Timken.

When adding the Ex-Brunauer Wax and the Cologne Bronze to the group (see fig. 13.5), the front profiles are again almost identical, with the Ex-Meek only slightly offset. The damage to the ExBrunauer Wax and the subsequent slumping of the wax around the neck area is evident. The Cologne Bronze corresponds well with the other four sculptures. In comparisons between the foreheads of the five sculptures, there is only a $3 \mathrm{~mm}$ distance between the innermost and outermost profile. In the area just below the nose, this difference is reduced to less than $2 \mathrm{~mm}$. 


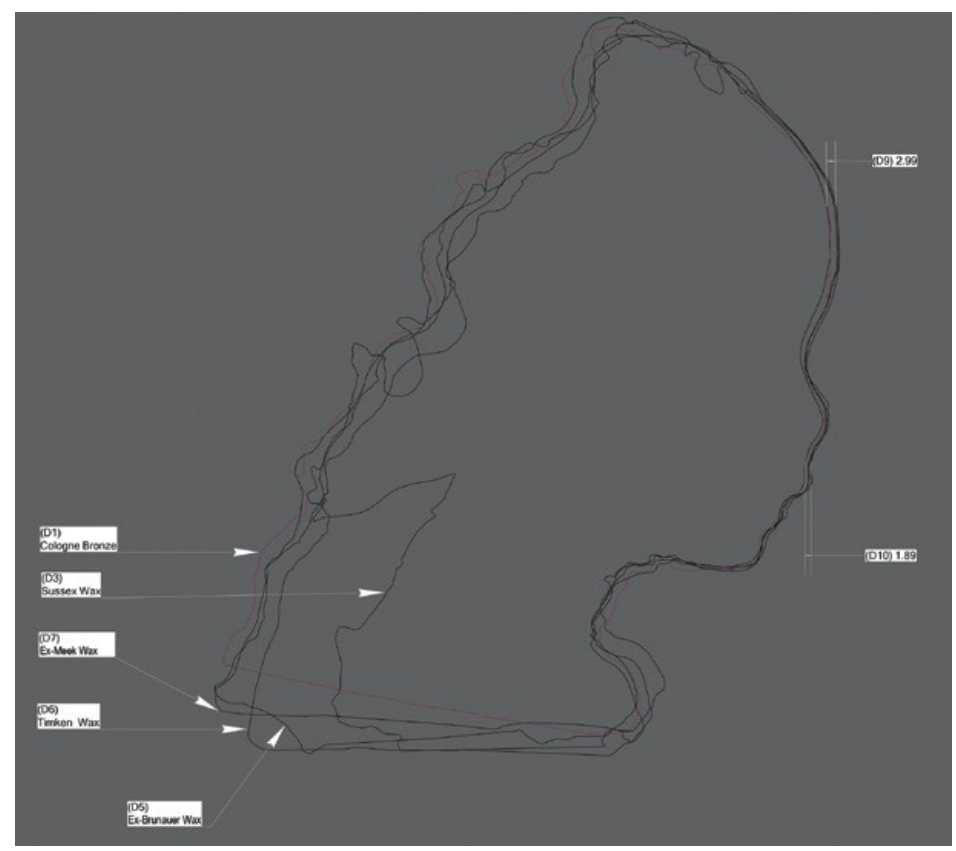

Figure 13.5 Cross-section comparison of five Bambino ebreos (c) Ronald Street

An interesting result is the obvious similarity between both the sculptures' faces, where the models overlay each other nearly perfectly, and the backs of the heads. However, at the same time, the profiles of the backs of the heads are displaced by a distance of several millimeters. This is clearly visible in the Ex-Meek and Timken waxes (fig. 13.6). If both sculptures were made out of the same mold, they should have similar dimensions, but the Ex-Meek Wax is larger. To better understand the results of these surface comparisons, a proper investigation into Rosso's process is needed.

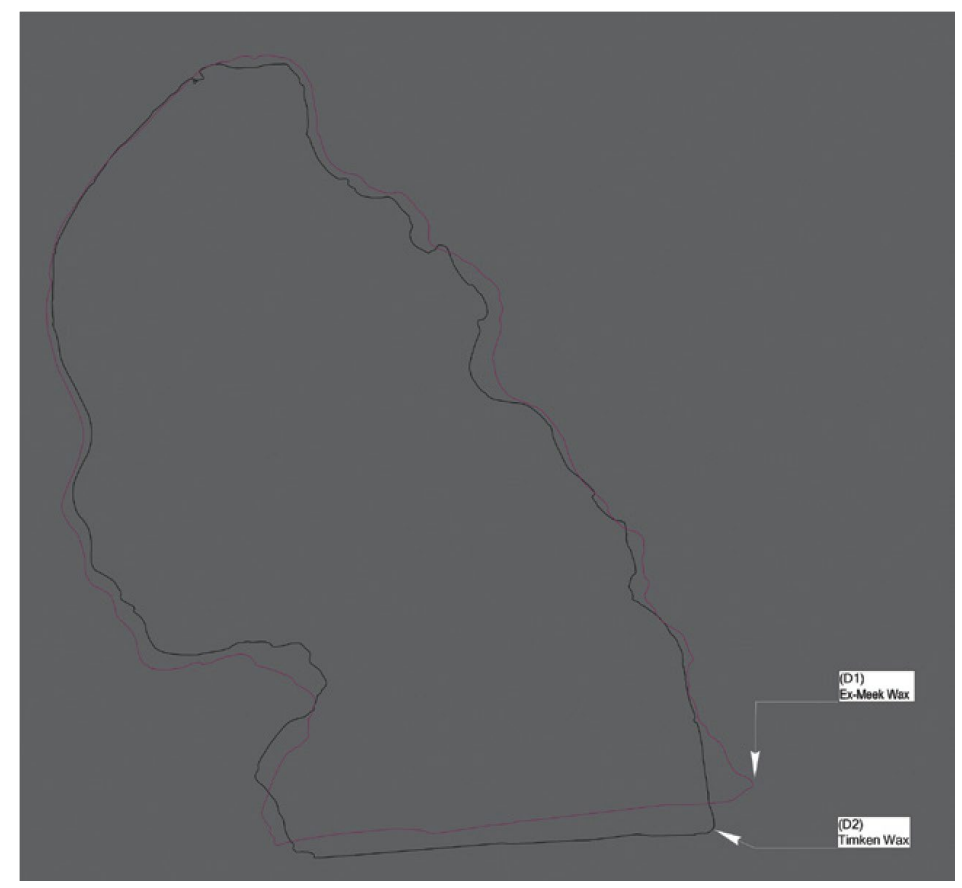

Figure 13.6 Cross-section comparison of the Timken and Ex-Meek waxes. Similarities are clearly visible in the front and back, but the sculptures differ in size @ Ronald Street 


\section{Contextualizing the Digital Repositories}

Henry Lie ${ }^{225}$ and Derek Pullen ${ }^{226}$ have already provided an overview of how Rosso produced his casts: he made the bronze casts using the lost-wax method. During this process, wax models of the sculpture are needed as an intermediate step. This is why the same working method can be postulated for producing the wax variations of the Bambino ebreo. For the creation of a new sculpture, Rosso made a first version in clay. Clay is easy to handle, sculpt, and model, but it is not durable or consistent in form and therefore unsuitable for making casting models. Thus a first model is built around the clay, and after drying, the clay must be washed out and the model filled with plaster. This results in a plaster master copy, called by Lie a "primary plaster."227 Around this plaster sculpture the gelatin mold is applied, which is needed for serial production. The next step involves filling the gelatin mold with a wax layer and then filling the wax with plaster. The result may be a finished wax sculpture, or when supported with "core pins" and surrounded with additional plaster, it will create a model used for bronze casting. ${ }^{228}$ Gelatin molds only have a limited durability before they dry out, and they lose detail and definition and become damaged during use. Plasters are more durable and can be used more often to produce new gelatin molds, providing a perfect basis for serial production. ${ }^{229}$

Especially for the Bambino ebreo, which Rosso cast in a bigger series, the evidence for the use of plaster models and gelatin molds is convincing. Lie used a cast of Rosso's Bookmaker from Galleria Nazionale d'Arte Moderna in Rome and a Bambino Malato from the Civica Galleria d'Arte Moderna in Milan to point out artifacts (accidentally produced features) of the casting process, which are also part of Rosso's creative process. ${ }^{230}$ In these samples, both sides of the gelatin molds were "completely out of registration, resulting in a large step or offset along the front-to-back dividing line at both sides of the figure." ${ }^{231}$ This is another important detail about Rosso's process: the offset may result in variations in the size and volume of the sculpture even when using the same gelatin mold for two or more casts.

For a proper digital comparison of the Bambino ebreo casts, these aspects of Rosso's process must be considered. What are the possible issues? The casts with the closest similarities may come from identical gelatin molds, although this is impossible to determine purely from the casts. Or the similarities may result from the fact that the sculptures come from different gelatin molds applied to the same plaster. This is easier to determine from defects or small irregularities on the plasters that are recorded in the gelatin molds and then transferred to the final casts. Although normally in casting

\footnotetext{
${ }^{225}$ Henry Lie, "Technical Features in Rosso's Work," in Cooper and Hecker, Medardo Rosso: Second Impressions, 69-93.

226 Pullen, “Gelatin Molds," 96-102.

227 Lie, “Technical Features in Rosso's Work," 70-71.

228 Ibid.

229 Bohnagen, Der Stukkateur und Gipser, 114-30.

230 Lie, "Technical Features in Rosso's Work," 77.

231 Ibid., 76.
} 
only one primary plaster is produced, from which secondary casts are then taken, Rosso may have made more than one plaster to create several copies of the same sculpture, perhaps even at the same time. These multiple plasters may have been created by using existing wax casts or plaster models of the sculpture to make new gelatin molds or new plasters. Furthermore, Rosso may have combined parts or halves of different gelatin molds, leading to misalignment of the molds and subsequent differences in the volumes. It is also possible that he reworked the waxes after casting. ${ }^{232}$ Further casts were produced from Rosso's plaster models by his son Francesco after his death. ${ }^{233}$

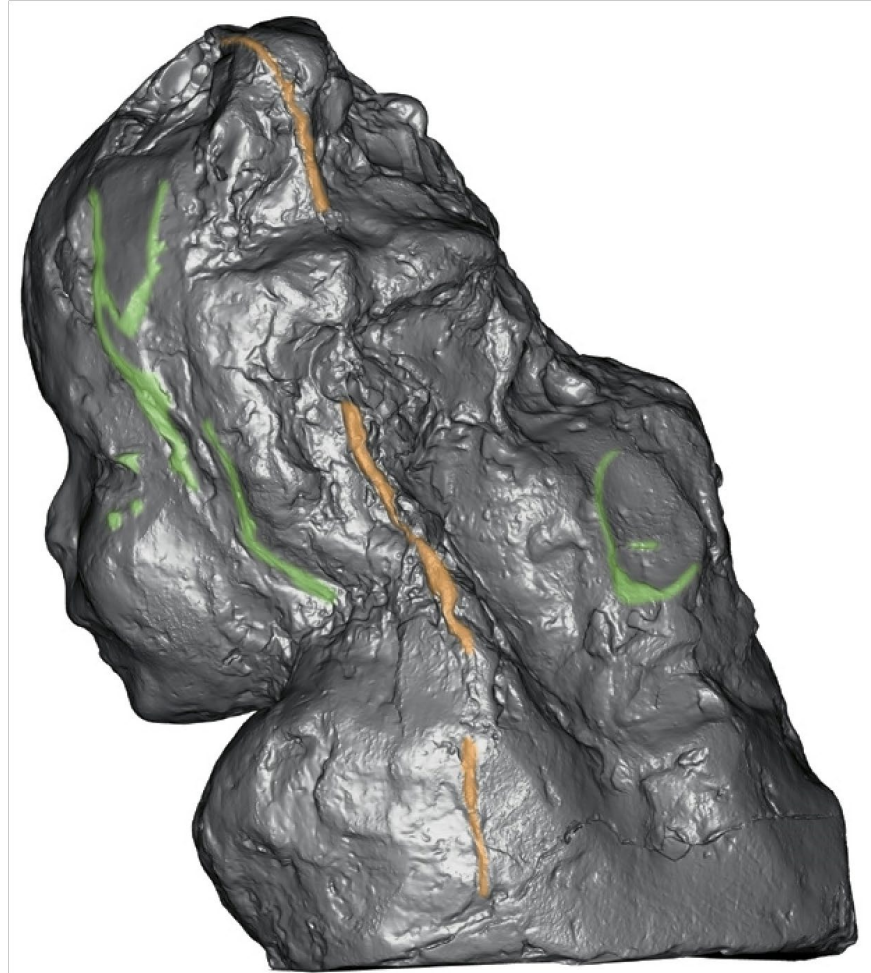

Figure 13.7 Timken Wax. Border line of the halves of the mold is traced in orange (c) Max Rahrig

Special methods are required for processing the alignments to achieve surface comparison of the 3D models. First of all, in order to understand how many parts where used for the gelatin molds, variants with artifacts of misaligned molds are helpful. In the case of the twelve Bambino ebreo casts of this study, artifacts are found on seven sculptures: the Ex-Monti, Nasher, and Timken waxes and the Cologne, Ex-Bergamo, Folkwang, and Kröller-Müller bronzes. All of the artifacts divide the sculpture into two halves only. The borderlines run exactly between the more natural and realistically modeled faces and the rather more abstract backs of the heads (fig. 13.7). Since there are no complicated undercuts existing in the sculpture, there is no need to split the molds into more than two parts.

\footnotetext{
232 Ibid., 71.

233 Sharon Hecker, "The Afterlife of Sculptures: Posthumous Casts and the Case of Medardo Rosso (18581928)," Journal of Art Historiography 16 (June 2017), 1-18, https://arthistorio graphy.files.wordpress.com/2017/06/hecker.pdf.
} 


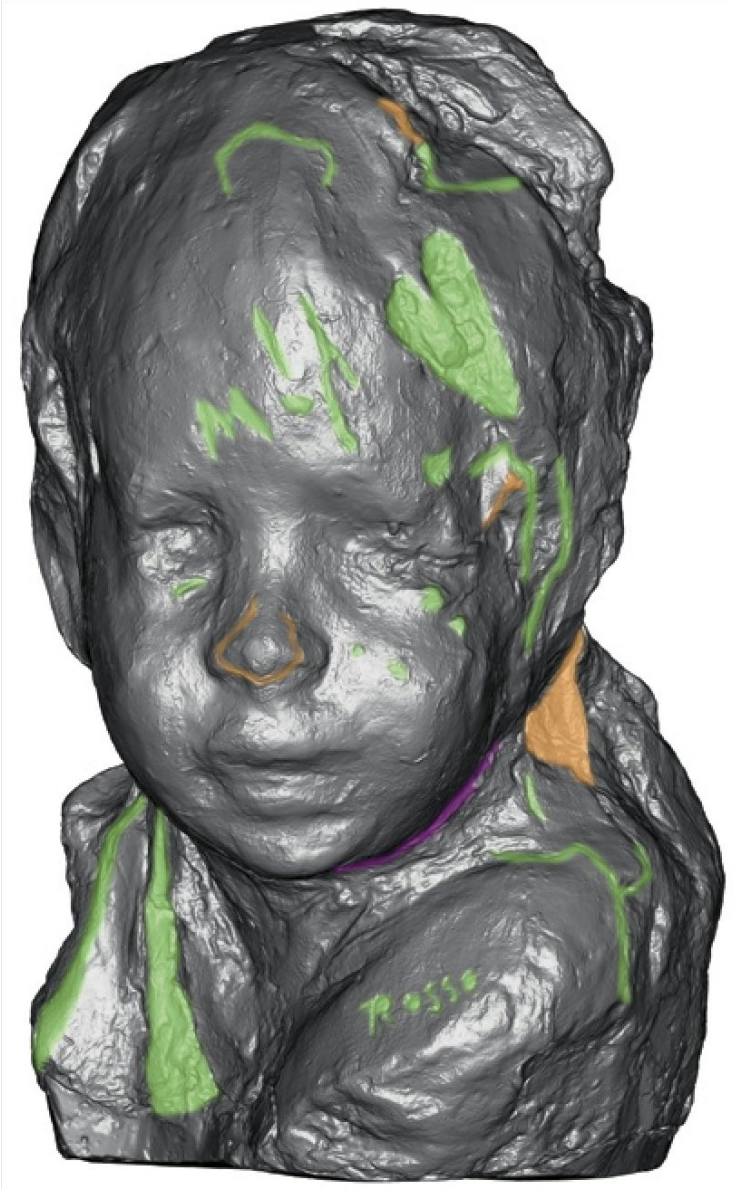

Figure 13.8 Ex-Monti Wax with a mapping of key features (green) and unique characteristics (orange) (C) Max Rahrig

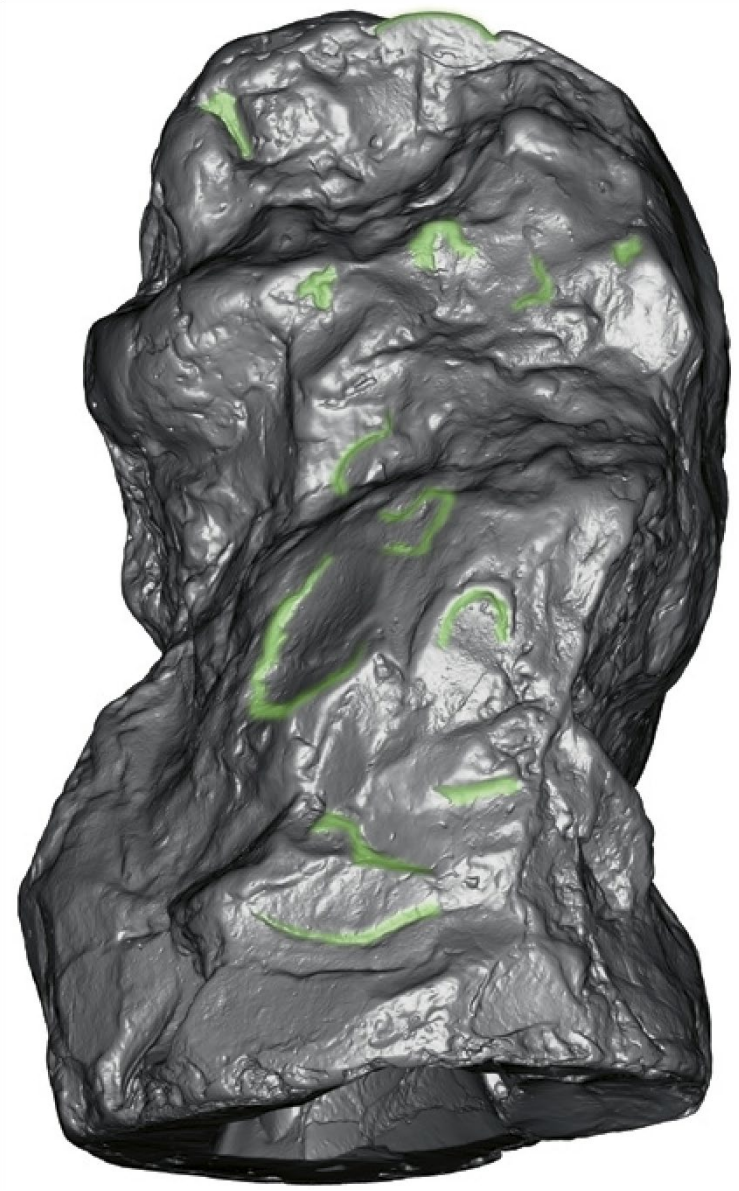

Figure 13.9 Ex-Pawlowski Wax with a mapping of key features (green) (C) Max Rahrig

Based on this observation, it should therefore be sufficient to calculate the comparisons based on the alignment of the faces and backs separately. A detailed observation of surface details may also give a first basis for a pre-selection into possible groupings. If small irregularities and damages are found on different Bambino ebreo casts, they may work as key features indicating the use of the same plaster model from which gelatin molds were taken. Possible key features are the details on the brow, the nearly heart-shaped detail on the right side of the forehead, and the slightly protruding structure a little further up the head (fig. 13.8). (Details could result from direct modeling or touching up of the surface at an earlier stage in a version's production, or they could be cast from features in a mold surface. If one has more than one version with fine detail, differences in the crispness of the detail can give a clue as to the relationship between the examples.) The pea-like structure in the left eye, the irregularities on the right cheek, and the shape of the left collar can also be used as key features. On the back of the head, possible key features include the fingerprint on the right and the surrounding structures and the shape and details in the upper area (fig. 13.9). This fingerprint may also be a result of handling the finished wax cast. 


\section{Comparison of the Faces}

The Ex-Monti Wax provides very sharp surface details, which may indicate that it was cast from mold that had not been used many times before. Thus this sculpture may function well as the reference model for surface comparisons of the sculptures' fronts. For the alignment, only the area of the face (brow, eyes, nose, mouth, and cheeks) was used. Four Bambino ebreo casts have strong similarities to the Ex-Monti Wax, the faces of the Nasher Wax and the Cologne, Folkwang, and Ex-Bergamo bronzes fitting nearly perfectly. All of them have identical key features regarding the details on the brow, the dimension of the heart-shaped detail on the right side of the forehead (especially its inner part), as well as the slightly protruding structure a little further up the head.

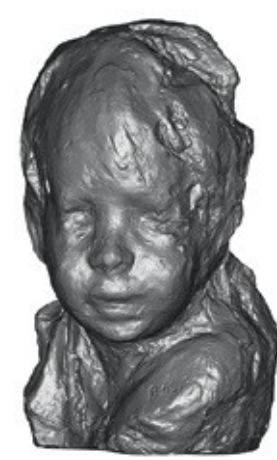

Ex-Monti wax (reference)

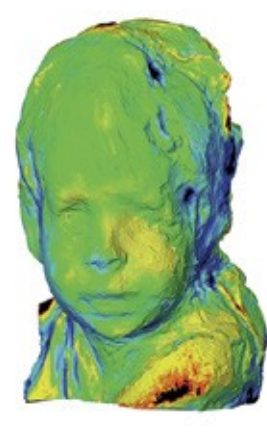

Nasher wax

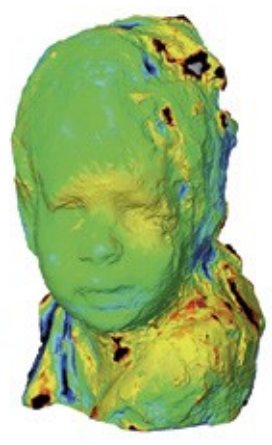

Cologne bronze

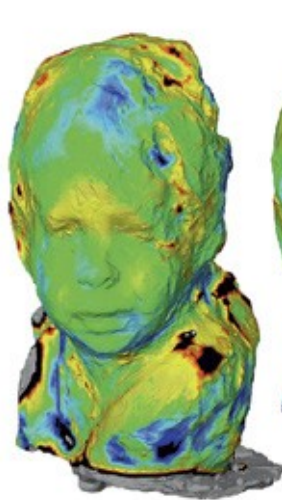

Folkwang bronze

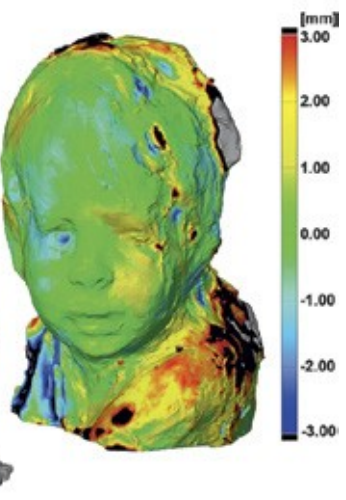

Ex-Bergamo bronze

Figure 13.10 3D comparison of the Ex-Monti Wax to the Nasher Wax and the Cologne, Folkwang, and Ex-Bergamo bronzes (C) Max Rahrig

For processing all further 3D surface comparisons, GOMinspect software was used with the same color-scale for deviation mapping. The color-scale shows consistencies of $+/-1 \mathrm{~mm}$ in green, deviations from $+1 \mathrm{~mm}$ up to $+3 \mathrm{~mm}$ are yellow to red, and deviations between -1 down to $-3 \mathrm{~mm}$ are light to dark blue. All larger deviations are shown in black and gray. The surface comparisons of the four sculptures to the Ex-Monti Wax reveal how exactly they fit together: in all four cases most of the face has a consistency of under $+/-1 \mathrm{~mm}$ to the Ex-Monti (fig. 13.10). The light blue and yellow areas in the faces result from deviations between $+/-1-2 \mathrm{~mm}-$ a range of deviation that can be caused by the flexible gelatin mold if the wax was filled in under pressure. In addition, different wax compositions and variations in the ambient and mold temperature affect the flexibility and viscosity, resulting in small deviations. The neck and bust vary more, perhaps because Rosso reworked them after wax casting, or possibly because he treated these areas less carefully than the face when he applied the wax to the mold. One can model additional detail or make changes directly in the wax after casting. Small surface cutting or scratching or stamping would be easy. However, real modeling of shapes would require a soft or warmed wax and seems less likely in Rosso's case.

Also of interest are the similar deviations between the two bronzes, Ex-Bergamo and Cologne. A direct comparison shows more clearly how accurately they fit together. The Ex-Bergamo Bronze has more 
highly detailed key features, so it was used as the reference model for processing the 3D comparison. There are only minor deviations in the shape and dimensions of the two bronzes (fig. 13.11); some parts of the Cologne Bronze are slightly smaller, maybe because of a different shrinking behavior during the casting process. It is therefore possible that both bronzes were cast from the same plaster model.

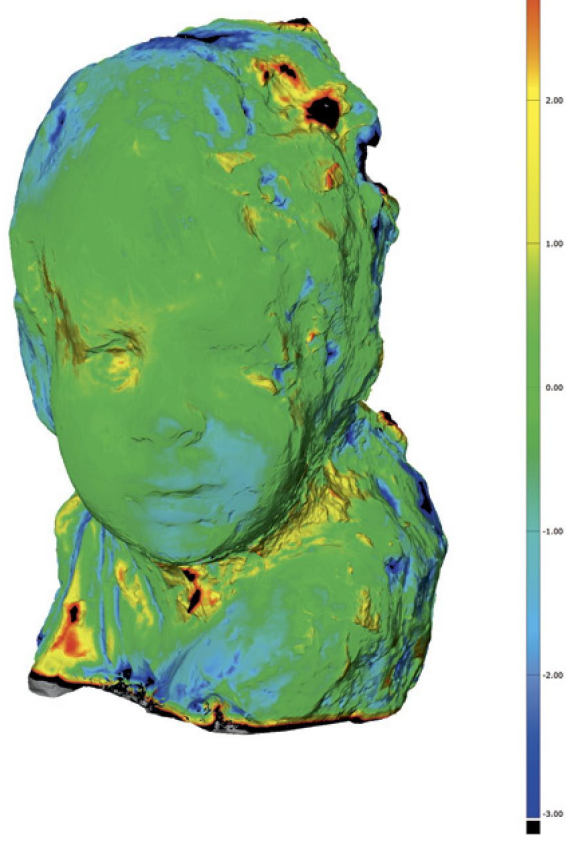

Figure 13.11 3D comparison of Ex-Bergamo and Cologne bronzes. Visualization of the comparison is shown on the Cologne model (C) Max Rahrig

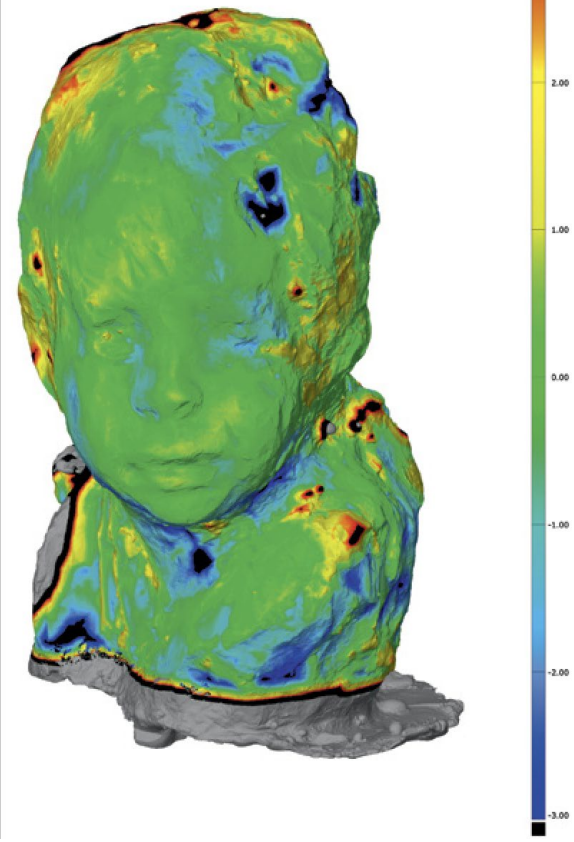

Figure 13.12 Comparison of Cologne and Folkwang bronzes. Visualization based on Folkwang Bronze@ Max Rahrig

Many parts of the Folkwang Bronze look similar to the Cologne Bronze (fig. 13.12). Proportions of the head and even parts of the bust appear similar, but a closer look at the Folkwang Bronze reveals obvious differences. The Folkwang Bronze has a curved left collar instead of a straight one; furthermore, the bust is several centimeters taller and the right part of the bronze has a flange with holes for aligning a gelatin mother mold. In this case, the excess wax for creating the lost-wax form may have been applied over the edge of the mother mold, perhaps to improve it or repair an area of loss. ${ }^{234}$

It is conceivable that the two sculptures were created from the same plaster model. The wax in the area of the collar in the Cologne Bronze was not applied to the mold completely, leading to a smaller model in comparison with the other bronzes. One explanation for the differences in surface details between the Cologne and Folkwang bronzes is that the plaster model could have been damaged, perhaps the plaster model was damaged, which would suggest that the Cologne Bronze was made

\footnotetext{
${ }^{234}$ Lie, "Technical Features in Rosso's Work," 80-81.
} 
after the Folkwang Bronze. This might explain why the details on the forehead and the heart-shaped structure of the Cologne Bronze are more blurred. Due to the similarities in the traces of bronze casting, one might imagine that the two versions were cast in the same workshop. However, metallurgical analysis of the composition of the two bronzes revealed that they were not made out of the same melt. ${ }^{235}$ The strong deviations in some places between the two sculptures can be explained by residues of plaster investment left over from the casting process, which still adhere very strongly to the Folkwang Bronze.

A second group is represented by the Ex-Pawlowski, Ex-Meek, Sussex, and Timken waxes (fig. 13.13). Their faces have similar proportions, and key features like the heart-shaped detail on the right side of the forehead are different from the Ex-Monti group. All four sculptures have a scratch under the left eye and two artifacts under the right eye instead of the four artifacts found in the Ex-Monti group. But there are huge differences between the objects in this group, too, especially in the shape of the busts. Perhaps Rosso created the sculptures by using the same plaster model for the faces but reworked the wax busts after casting the waxes or while filling the waxes with plaster.

Two Bambino ebreo casts were impossible to compare to the others: the Ex-Brunauer Wax was in a very poor condition while scanning, and due to the deformations and degradation of the surface, no accurate comparison to the other sculptures was possible. In the case of the Kröller-Müller Bronze, another scanning device with a lower resolution was used. As a result the 3D model does not contain enough surface detail for a straight comparison with the others. But in both cases, the proportions and size of the Bambino ebreo cast are similar to the others, and therefore a casting from plaster models similar to the other sculptures is obvious.

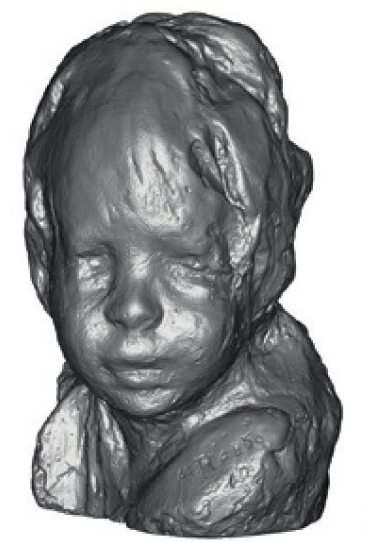

Ex-Pawlowski wax (reference)

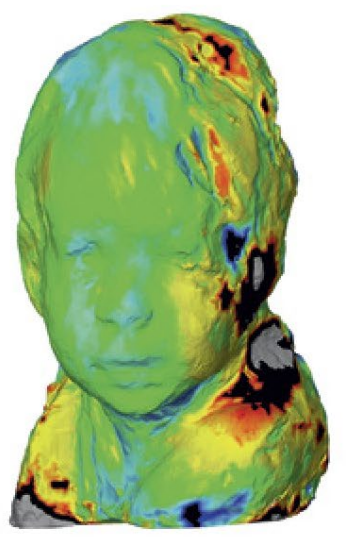

Ex-Meek wax

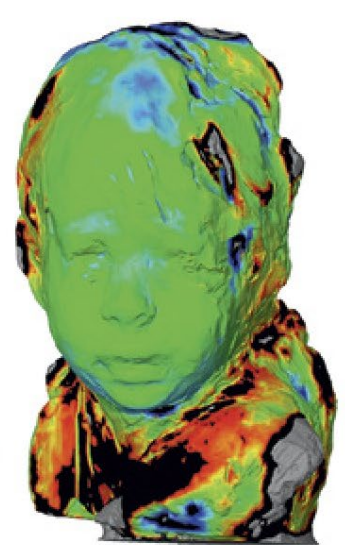

Sussex wax

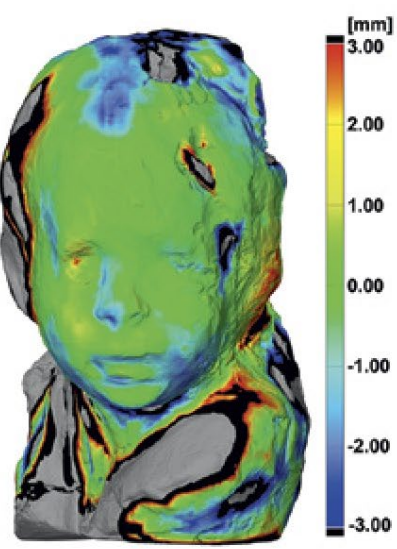

Timken wax

Figure 13.13 Comparison of the Ex-Pawlowski Wax to the Ex-Meek, Sussex and Timken waxes (C) Max Rahrig

\footnotetext{
${ }^{235}$ See Federico Carò and Luc Megens, "Towards an Understanding of Rosso's Casting Practice: Surface XRF of Four Bronze Casts of Bambino ebreo," in this book, 272.
} 


\section{Comparison of the Back Sides}

Regarding the more abstract shape of the back of the heads, observation of key features is more difficult. Nevertheless, there are some characteristic scratches, fingerprints, and surface details that can be found in several casts. In figure 13.9, these key features are highlighted on the Ex-Pawlowski Wax, which does not have many unique characteristics. The series comparison of the reverses of the Bambino ebreo casts can be separated into three groups.

First of all there is the group with characteristic similarities to the Ex-Pawlowski Wax. Four sculptures belong to this group: the Ex-Bergamo and Kröller-Müller bronzes, the Ex-Meek Wax, and the Black Plaster (fig. 13.14). In the comparison between the Ex-Pawlowski and Ex-Meek waxes, it can be seen that the basic shape is remarkably similar, but in the Ex-Meek the bulge above the left ear is missing. In general, the Ex-Meek has some smaller features compared to the Ex-Pawlowski. The Ex-Bergamo Bronze also has a very similar basic shape to the Ex-Pawlowski, but it is noticeable that the key features are all less accentuated, probably due to the additional steps involved in going from the wax model to the finished bronze casting, and the resulting loss of sharpness of detail. The Kröller-Müller bronze matches the Ex-Pawlowski Wax very well. Some areas are larger, but these are mostly casting artifacts. The key features are partly smaller, but this can perhaps be explained by the oscillation process in bronze casting. ${ }^{236}$ The last object in this group of well-matching Bambino ebreo casts is the Black Plaster version. The proportions match well with the Ex-Pawlowski Wax, but it is noticeable that the key features are larger. This fact will be discussed in more detail below.

The second group consists of the Bambino ebreo casts that do not match quite as well with the ExPawlowski Wax (fig. 13.15). These are the Nasher and Ex-Monti waxes as well as the Folkwang Bronze. All three models differ from the Ex-Pawlowski in similar ways. They are generally somewhat smaller in size, which also makes the key features smaller.

The third group includes all the Bambino ebreo casts that deviate substantially from Ex-Pawlowski, so that no real similarities or indications of the use of the same plaster model can be inferred. This group includes the Timken, Sussex and Ex-Brunauer waxes as well as the Cologne Bronze (fig. 13.16). ExBrunauer shows such striking deviations in the geometry, due to the large damaged area on the back, that a clear comparison of the surfaces is not possible. In many areas the Timken Wax is larger, and while the upper area shows some similarities to Ex-Pawlowski, the middle area especially, where most key-features are located, differs in size. The Cologne Bronze, on the other hand, matches Ex-Pawlowski comparably well in the middle part. What is particularly noticeable here, however, is that the

\footnotetext{
${ }^{236}$ Paul Bellendorf, Metallene Grabplatten aus Franken und Thüringen aus dem 15. bis 18. Jahrhundert: Eine interdisziplinäre Studie zum Denkmalbestand und seiner Gefährdung durch Umwelteinflüsse (Hamburg: Saarbrücken Südwestdeutscher Verlag für Hochschulschriften, 2011), 29.
} 
fingerprint is missing, and while the upper part is clearly smaller, the lower part of the sculpture is again larger. While it is important to record this difference, something as fine as this might be lost in any of the steps for making a wax, plaster or bronze. Finding it on two casts would have meaning. Not finding it on a cast might mean it has simply been lost or not transmitted. The Sussex Wax shows the strongest deviations: it is obvious that the back does not show even the slightest similarities to the other Bambino ebreo casts.

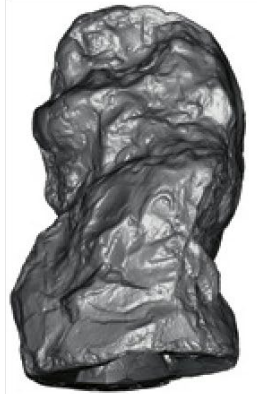

Ex-Pawlowski wax (reference)

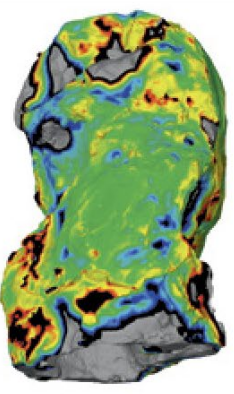

Ex-Bergamo bronze

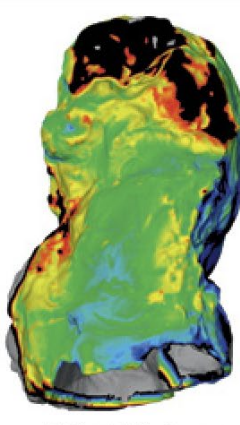

Krö̈ller-Müller bronze

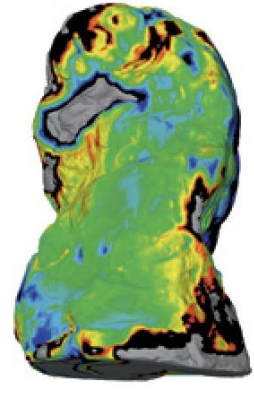

Ex-Meek wax

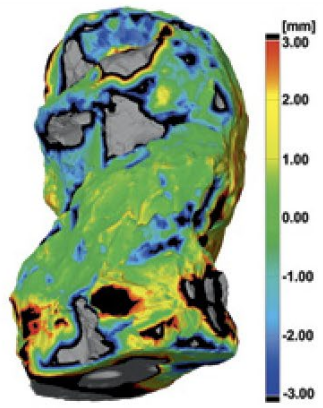

Black Plaster

Figure 13.14 Comparison of the Ex-Pawlowski Wax to the Ex-Bergamo and Kröller-Müller bronzes, the Ex-Meek Wax and Black Plaster (C) Max Rahrig

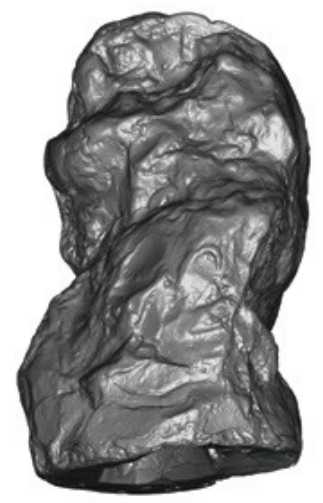

Ex-Pawlowski wax (reference)

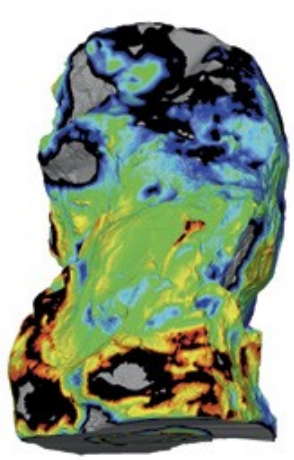

Nasher wax

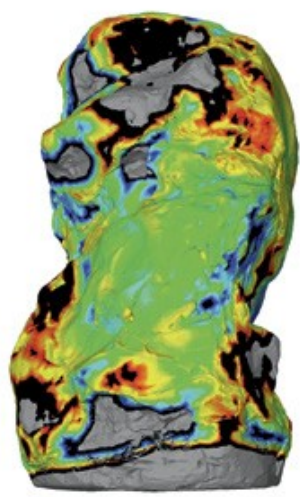

Ex-Monti wax

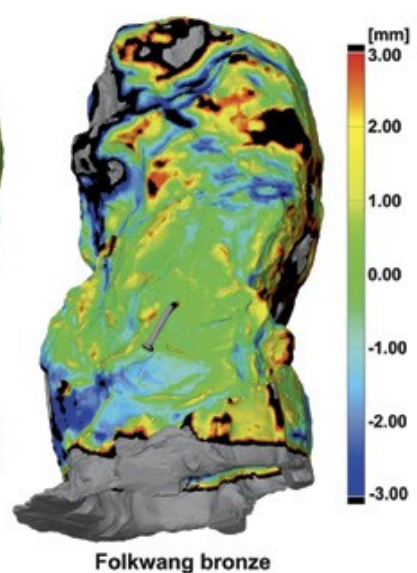

Folkwang bronze

Figure 13.15 Comparison of the Ex-Pawlowski Wax to the Nasher and Ex-Monti waxes and the Folkwang Bronze (c) Max Rahrig

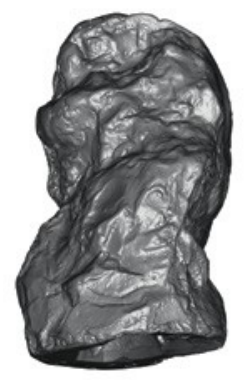

Ex-Pawlowski wax (reference)

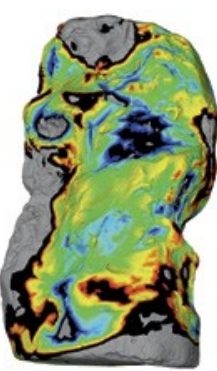

Timken wax

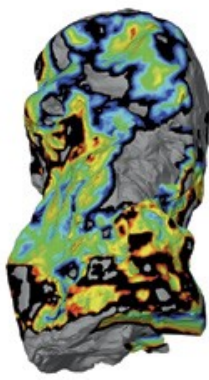

Ex-Brunauer wax

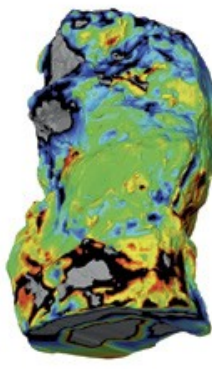

Cologne bronze

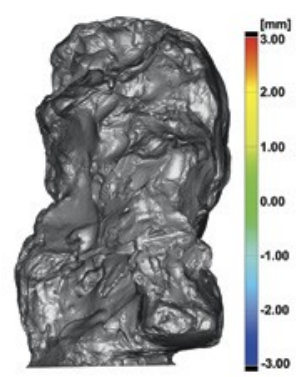

Sussex wax

Figure 13.16 Comparison of the Ex-Pawlowski Wax to the Timken, Ex-Brunauer and Sussex waxes and the Cologne Bronze (C) Max Rahrig 
A comparison of the back sides of all these waxes apart from the Sussex and Ex-Brunauer shows that similarities can only be found in the middle area around the fingerprint, while the upper parts vary considerably. This may be due to damage to the wax casts within the last hundred years, but the deviations are also striking in the dimensionally stable bronzes. The same applies to the lower part and the base of the sculpture. It can therefore be hypothesized that Rosso either used only a partial plaster model from which he made a gelatin mold for the middle area for the design of the reverse sides, or that the reverse sides were heavily reworked by hand after casting, with portions, mounts and bases removed or added. It is hard to think of these reworkings as the careful improvements to modeling a wax that might happen with a more traditional artist/studio. Rather, they suggest cruder changes and repairs of problems. It is also possible that Rosso cast the Bambino ebreo by using only a one-sided or open gelatin mold, as Lie assumed for the Grand Rieuse sculpture. ${ }^{237}$ In this case, the similarities in the middle part may be due to ordinary processing reasons. It is possible that Rosso applied the wax into an open gelatin mold for the face. After the wax set he may have applied the plaster core of the sculpture and reworked the back side by hand before applying the wax there. The shape of the middle part strongly recalls a negative form of the palm of a left hand. If it were assumed that Rosso's palm did not change significantly in size over the years, and if he worked in a recurring pattern due to serial production, this could also provide an answer to the strong similarities between the sculptures even without using a mold. This could also explain the fingerprint, which is always in the same place but differently accented. It could therefore be the print of Rosso's left thumb, leaving its negative form on the wax while holding the sculpture in his warm hand during the reworking process of the face. This theory is corroborated by the strong variations in the design of the back of the Sussex Wax, where Rosso may have simply deviated from his process. It is also possible that the Sussex Wax was one of the early versions of Rosso's Bambino ebreo, at a time when his process was not yet optimized.

\section{Surface Comparison to a Plaster Model}

The data set of one Bambino ebreo, the Black Plaster, raises questions and possibilities that will now be examined in more detail. Unfortunately, the exact circumstances regarding the origin of the dataset cannot be traced in detail at present. But it is the only 3D scan of a Bambino ebreo plaster model in this study, representing one of the two plaster models known. The surface resolution of the 3D dataset is lower than the other Bambino ebreo sets. The dataset was probably not digitized during the workshop and a different scanning device was used. ${ }^{238}$

The key features are relatively unclear in the dataset, but there are still some recognizable characteristics, such as the two artifacts under the right eye. Nevertheless, the overall geometry of the

\footnotetext{
237 Lie, "Technical Features in Rosso's Work," 75.

${ }^{238}$ Correspondence on the background of the dataset can probably be found in Ron Street's documents, but they were not accessible posthumously.
} 
Black Plaster in comparison with the other Bambino ebreo casts provides some interesting results (fig. 13.17). ${ }^{239}$ The Ex-Brunauer Wax shows the greatest deviations from the Black Plaster. This is due to surface loss, particularly in the area around the eyes, and is probably directly related to its poor condition. Apart from artifacts of the casting process, such as casting welds or the presence of plaster investment, it is noticeable that the faces of all the other Bambino ebreo casts made of wax and bronze are slightly smaller compared to the Black Plaster. The deviations range from 1 to $3 \mathrm{~mm}$ and are found under the chin as well as on the sides and at the top of the forehead. It is therefore a uniform deviation spread around the whole face. In a historical workshop book about the stuccoer's craft, it is pointed out that wax models are subject to shrinkage. The reason for this can be found in the processing of the wax, partly mixed with additional materials and heated up for processing and application in the mold. Afterwards, the wax shrinks as it sets. ${ }^{240}$ The same can be said for the bronze casting process, where there is an obvious loss of volume between the hot molten bronze and the finished cooled one. ${ }^{241}$

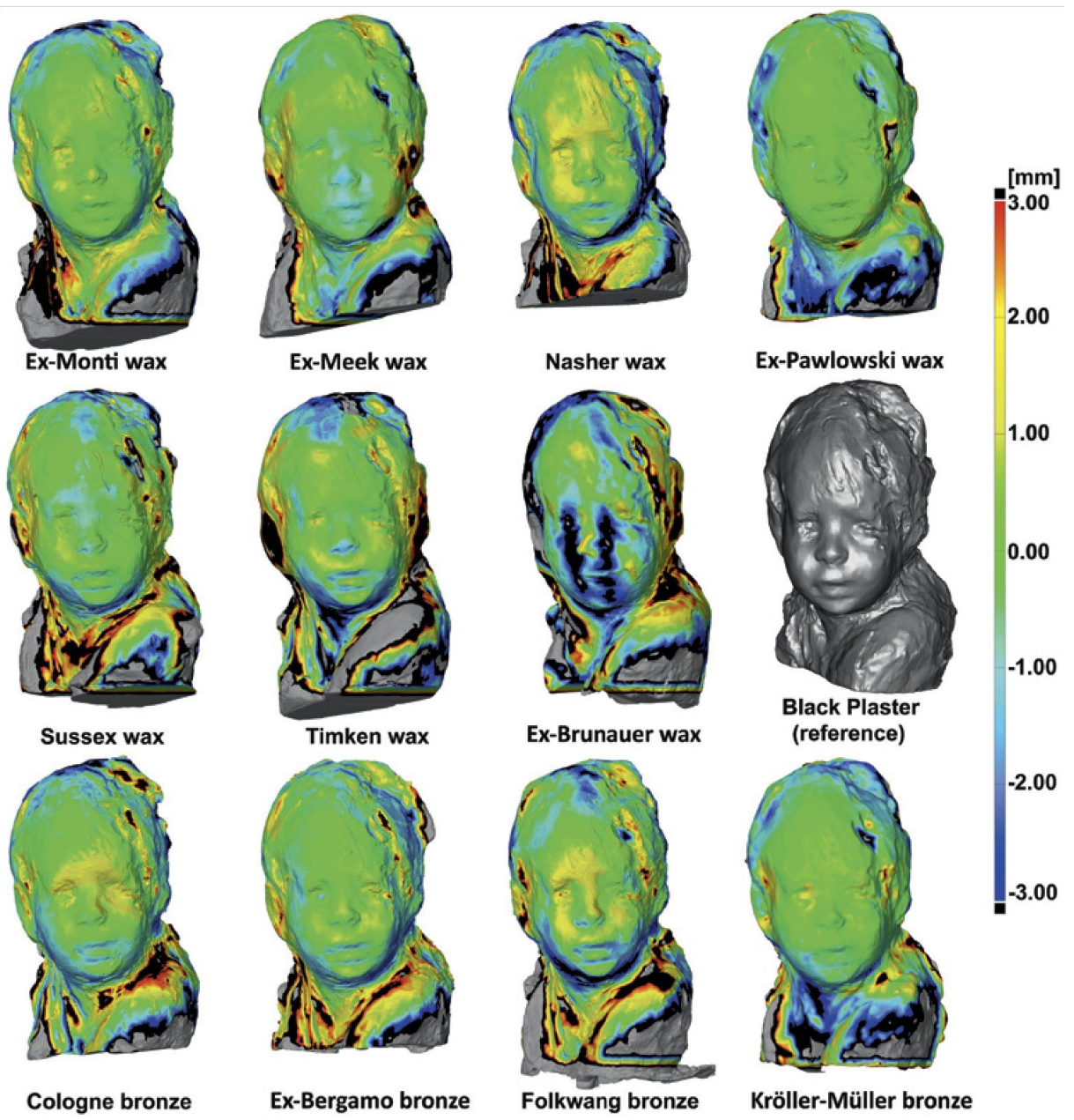

Figure 13.17 Comparison of the Bambino ebreos to Black Plaster@ Max Rahrig

\footnotetext{
${ }^{239}$ Due to the generally very high differences between the models in the backs of the heads, the following comparisons are limited to the faces of the Bambino ebreo casts.

${ }^{240}$ Bohnagen, Der Stukkateur und Gipser, 114.

${ }^{241}$ Bellendorf, Metallene Grabplatten aus Franken, 29.
} 
Regarding this, a detailed consideration of Lie's article reveals some interesting aspects regarding the reasons why Rosso and other artists made models out of plaster: as a basis for casting in wax and bronze; or to obtain a cheap reproduction of a sculpture, which, after casting, can be painted in any color, or, less likely in Rosso's case, painted bronze as a preliminary study to check whether the arrangement of light and shadow or the general effect of the sculpture fulfills the idea of the artist before carrying out an expensive bronze cast. ${ }^{242}$ Such studies are practical and useful for sculptures that are to be cast only once or in a small series, but Rosso is not known to have made preliminary studies for other works. There is another reason why a plaster model is needed: as the primary plaster in Rosso's process, used as the basis for creating the gelatin molds. ${ }^{243}$ As Lie writes:

Coming directly from the artist's unique models, they offer the most accurate renditions of Rosso's initial concepts for his limited number of sculptural themes. And they serve as reference points for judging the degree of detail preserved in subsequent casts. Later versions will always offer detail diminished by an amount corresponding to the number of generations removed from the primary plaster. ${ }^{244}$

A hint that the Black Plaster most likely belongs to the group of primary plasters is provided by its key features, which are exclusively those that can be found on almost all the other Bambino ebreo casts. Features like the two additional artifacts on the right cheek next to the nose found on the Ex-Monti and Nasher waxes and Cologne, Folkwang, and Ex-Bergamo bronzes are missing, and perhaps these "secondary features" are due to damages in the gelatin mold used.

A second indication that this is a primary plaster is given by the dark color of its surface. In the workshop book from 1914, Bohnagen mentions that it is necessary to apply siccative (oil drying agents) made from oil or shellac onto the plaster before applying the gelatin mold. The oil layer acts as a barrier preventing the gelatin from sticking to the plaster. This layer will certainly lead to tanning or darkening of the plaster. ${ }^{245}$ An example for such tanning is given by Harry Cooper and Sharon Hecker in their analysis of Rosso's Bookmaker sculpture. ${ }^{246}$ It is known that Rosso needed more than one primary plaster of the Bambino ebreo. Due to the abrasion of the surface and a gradual loosening of the detail sharpness caused by frequent copying, several plaster models were necessary. It is also conceivable that Rosso used several primary plasters of the same sculpture at the same time in order to be able to create several copies simultaneously. In Lie, for example, another plaster or clay version of the

\footnotetext{
242 Lie, "Technical Features in Rosso's Work," 71.

243 Ibid., 70.

244 Ibid., 80.

245 Bohnagen, Der Stukkateur und Gipser, 114.

${ }^{246}$ Harry Cooper and Sharon Hecker, “Catalog No. 13: Medardo Rosso, Bookmaker (L'uomo alle corse), c. 1894, plaster," in Cooper and Hecker, Medardo Rosso: Second Impressions.
} 
Bambino ebreo is shown, which unfortunately could not be included in the study here. ${ }^{247}$ The uniform deviations on the forehead of the Nasher Wax and the Cologne and Folkwang bronzes could indicate that there was another primary plaster.

A closer look at the surface comparisons of the Bambino ebreo casts with the Black Plaster suggest that the uniform deviations and similarities between the sculptures only affect the face and the area where the child's skin is portrayed. The chest and collar look superficially similar from one sculpture to another. The 3D comparisons, however, reveal that in fact there are substantial differences. A clear line can be followed along the boundary between the areas that match well and the areas with large differences. This line runs around the face, especially on the left side of the head, and it is clearly visible on the Ex-Monti, Timken, Nasher, and Ex-Brunauer waxes and also the Cologne and Ex-Bergamo bronzes (fig. 13.18) and under the chin of the Folkwang Bronze. This finding reveals another aspect of Rosso's process. It is to be hypothesized that only the face was cast using a gelatin mold, and either he made a rough copy of the other areas, or he reworked them considerably after casting. He seems to have taken a haphazard approach, making a few casts and then fixing them in whatever way needed if they had problems.

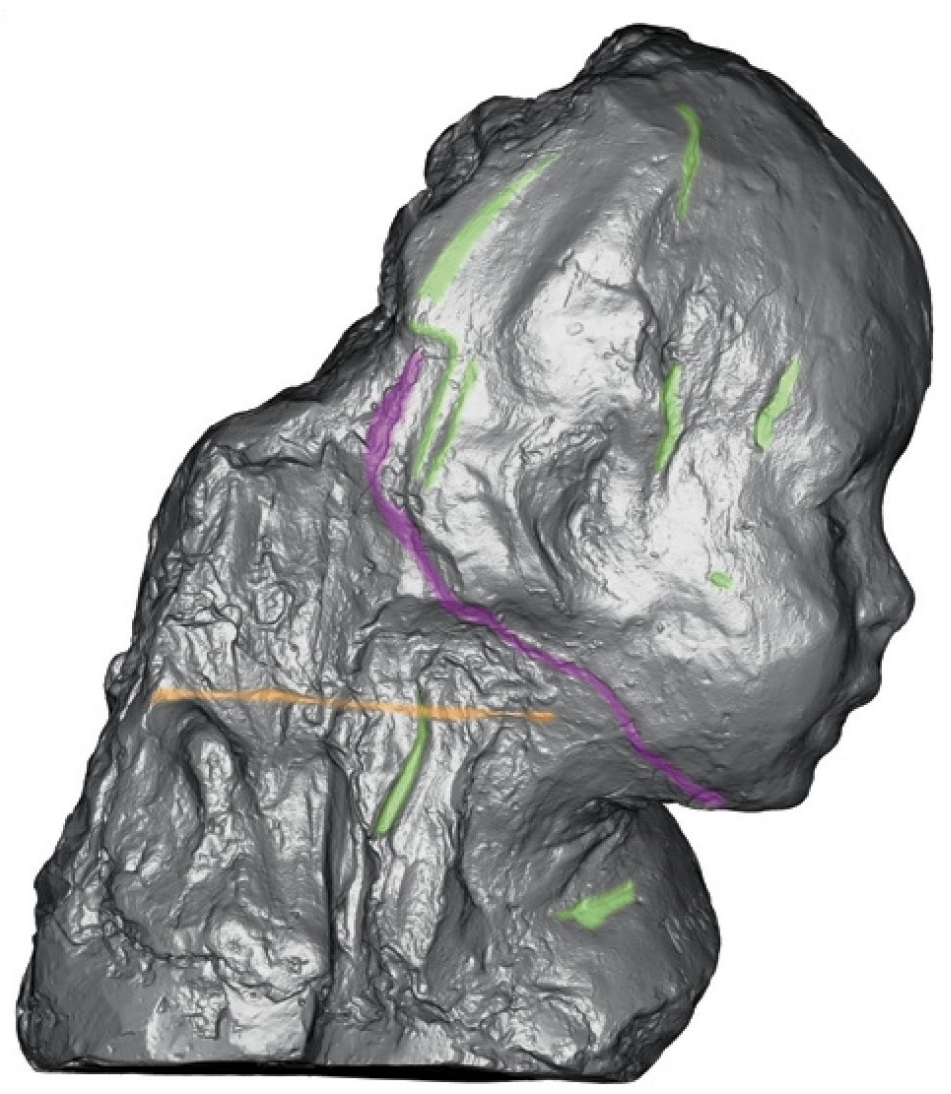

Figure 13.18 Ex-Monti Wax with a mapping of key features (green), unique characteristics (orange) and the border line of the gelatin mold (pink) (C Max Rahrig

${ }^{247}$ Lie, "Technical Features in Rosso's Work," 78. 


\section{Surface Comparisons as a Helpful Tool for Provenancing}

For sculptures whose object history is completely known and traced back to their production, it is very easy to give a statement on whether they were actually cast by Rosso or by someone else. However, the origin of some of Rosso's sculptures is not completely clear. This often leaves the question of the provenance unanswered. In some cases, digital surface comparison may provide helpful indications for the complex studies of provenance and connoisseurship of works of art.

For example, the specific provenance of the Ex-Pawlowski Wax could not be confirmed through external documentation. The comparisons between the front of this wax and the Ex-Meek, Sussex, and Timken waxes (see fig. 13.13) demonstrate a remarkable closeness, with Ex-Pawlowski and Ex-Meek particularly similar. If it can be hypothesized that Rosso created the faces by using gelatin molds and reworked especially the back sides, the greatest deviations would be expected on the back, particularly when the sculpture was not cast by Rosso. However, the comparison shows that the back sides of the Ex-Pawlowski and Ex-Meek waxes, the Ex-Bergamo and Kröller-Müller bronzes, and the Black Plaster (see fig. 13.14) are also very similar. This suggests instead that they were cast from the same plaster model.

Another sculpture with an unclear provenance, where the surface comparison may provide helpful information, is the Cologne Bronze. The distinctive similarities between the Folkwang and Cologne bronzes have already suggested that they were cast from the same plaster model. If the Cologne Bronze was cast after the Folkwang Bronze it would be smaller due to the shrinking behavior of the materials (bronze shrinks as the pour changes). This has already been shown with the Black Plaster, which is bigger than all of the wax and bronze sculptures. However, it is not possible to say definitively when the Cologne Bronze was cast. It could have been cast by Rosso himself, or later by someone else using an existing plaster model or wax version of a Bambino ebreo for a lost-wax casting.

These two examples show how 3D surface comparisons between pieces with a well-known history and those with an unclear history can help to find indications for further research in provenance and connoisseurship studies because they can display linkage or the lack of linkage between the objects. While 3D surface comparisons will not solve the complex study of the provenance of a work of art on their own, they may deliver essentials for further research.

\section{Conclusion}

This study has demonstrated that 3D comparison is an effective and useful tool for scientific observation and analysis of art objects and sculptures produced in series, verifying mathematically and analytically observations and assumptions whose statements were significantly confirmed. But the possibilities of digital surface comparisons are not only limited to the field of art history; they can also be used for comparative studies in other disciplines such as archaeology and building archaeology. It 
would be conceivable to use this method to compare building decorations or pottery produced in series. The method has the potential to reveal new information about the production of objects with stamped decorations from antiquity or the Roman period. ${ }^{248}$

In order to give clear statements about manufacturing techniques, however, it is necessary to consider all the information about the process. This may come from the literature and extensive studies of the objects. In the case of the Bambino ebreo casts, the knowledge that Rosso worked with misaligned molds during casting was essential in separating the surface comparisons between single parts of the mold. Without this information, the results of the surface comparison would have been misleading, because a best-fit matching calculated for the entire volume of the sculptures would try to compensate for the deviations caused by the misalignment.

This study provides some new evidence regarding Rosso's process in the creation of the Bambino ebreo. It has shown that when casting the sculptures he was focusing on keeping the shape and level of detail in the child's face as high as possible; the deviations in this region are negligible throughout the entire series of sculptures in this study. ${ }^{249}$ The other areas are reworked, which can be seen clearly in the back of the Sussex Wax. The Bambino ebreo casts are very similar, in that they share the same basic features and proportions. Nevertheless, Rosso has attached great importance to the casting process and reworking, whereby each Bambino ebreo has its own character. Despite the fact that the Bambino ebreo casts were produced in series, there exists no one hundred percent doppelganger.

Every single Bambino ebreo is characterized by Rosso's artistic freedom and his desire to create his own unique works of art. In his creative process, and in keeping with the spirit of his time, Rosso makes use of the technical possibilities and innovations of progressive industrialization. However, his works of art, even as serial products, retain their authenticity and uniqueness, avoiding the danger considered by Benjamin in "The Work of Art in the Age of Mechanical Reproduction." 250

\section{Acknowledgements}

First and foremost, my thanks go to Ronald E. Street, my co-author and the former editor of this fascinating study, who sadly passed away before the completion of the project. Ron created the 3D data sets of the Bambino ebreo casts and was already in the early stages of the comparative evaluation; he made some exciting observations and asked all the right questions. Many thanks also to Lluisa

\footnotetext{
248 See Dirk H. Rieke-Zapp and Elisabeth Trinkl, “Face to Face: Close Range Inspection of Head Vases," International Archives of Photogrammetry, Remote Sensing and Spatial Information Sciences 42-2/W5 (2017): 601-4, DOI: 10.5194/isprs-archives-XLII-2-W5-601-2017.

${ }^{249}$ Except for the differences in the Ex-Brunauer Wax, which are not due to the process of creation, but to the object's history over the last 100 years.

${ }^{250}$ Walter Benjamin, "The Work of Art in the Age of Mechanical Reproduction," in Illuminations: Essays and Reflections, ed. Hannah Arendt, trans. Harry Zohn (New York: Harcourt, Brace and World, 1969), $217-251$.
} 
Sarries Zgonc and Sharon Hecker, who gave me the opportunity to work on these studies. I hope Ron would be pleased with the results. I would also like to thank John Hindmarch, Ruth Tenschert and Chris Altmann from the Centre for Heritage Conservation Studies and Technologies (KDWT), University of Bamberg for their support.

\section{Bibliography}

Beentjes, Tonny P. C., Ronald E. Street, David Thurrowgood, and François Blanchetière. "3-D imaging as a research tool for the study of bronze sculpture." METAL 2013: Interim Meeting of the ICOM-CC Metal Working Group, Conference Proceedings, 16-20 September 2013. Edited by Ewan Hyslop, Vanesa Gonzalez, Lore Troalen, and Lyn Wilson. Edinburgh: Historic Scotland and International Council of Museums, 2013.

Bellendorf, Paul. Metallene Grabplatten aus Franken und Thüringen aus dem 15. bis 18. Jahrhundert: Eine interdisziplinäre Studie zum Denkmalbestand und seiner Gefährdung durch Umwelteinflüsse. Hamburg: Saarbrücken Südwestdeutscher Verlag für Hochschulschriften, 2011.

Benjamin, Walter. "The Work of Art in the Age of Mechanical Reproduction." In Illuminations: Essays and Reflections. Edited by Hannah Arendt. Translated by Harry Zohn. New York: Harcourt, Brace and World, 1969, 217-51.

Bohnagen, Alfred. Der Stukkateur und Gipser. Munich: Callway, 1987. First published in Leipzig, 1914.

Boulton, Ann. "Altered states: Henri Matisse's sculpture Aurora." American Institute for Conservation of Historic \& Artistic Works, Objects Specialty Group postprints, Vol. 14. Suite: 2007: 110-129.

Cooper, Harry, and Sharon Hecker, eds. Medardo Rosso: Second Impressions. New Haven: Yale University Press, 2003.

De Roos, Hans. "The Digital Sculpture Project Applying 3D Scanning Techniques for the Morphological Comparison of Sculptures." Computer and Information Science 9, no. 2 (2004): 1-84.

Furht, Borko. Encyclopedia of Multimedia. 2nd ed. New York: Springer, 2008.

Hecker, Sharon. A Moment's Monument: Medardo Rosso and the International Origins of Modern Sculpture. Berkeley: University of California Press, 2017.

Hecker, Sharon. "The Afterlife of Sculptures: Posthumous Casts and the Case of Medardo Rosso (18581928)." Journal of Art Historiography 16 (June 2017): 1-18, https://arthistoriography.files.wordpress.com/2017/06/hecker.pdf. 
Lie, Henry. "Technical Features in Rosso's Work." In Medardo Rosso: Second Impressions. Edited by Harry Cooper and Sharon Hecker. New Haven, CT: Yale University Press, 2003, 69-93.

Miyazaki, Daisuke, Mawo Kamakura, Tomoaki Higo, Yasuhide Okamoto, Rei Kawakami, Takaaki Shiratori, Akifumi Ikari, Shintaro Ono, Yoshihiro Sato, Mina Oya, Masayuki Tanaka, Katsushi Ikeuchi, and Masanori Aoyagi. "3D Digital Archive of the Burghers of Calais." 12th international conference on Interactive Technologies and Sociotechnical Systems, VSMM (Virtual Systems and Multimedia), October 18-20, 2006, New York: Springer, 2006: 399-407.

Newman, Timothy S., and Anil K. Jain. "A System for 3D CAD-based Inspection Using Range Images." Pattern Recognition 28, no. 10 (1995): 1555-74, DOI: 10.1016/ 0031-3203(95)00028-X.

Pullen, Derek. "Gelatin Molds: Rosso's Open Secret." In Medardo Rosso: Second Impressions. Edited by Harry Cooper and Sharon Hecker. New Haven, CT: Yale University Press, 2003, 96-102.

Rahrig, Max, Rainer Drewello, and Andrea Lazzeri. "Opto-Technical Monitoring: A Standardized Methodology to Assess the Treatment of Historical Stone Surfaces." International Archives of Photogrammetry, Remote Sensing and Spatial Information Sciences, 42-2 (2018): 945-52, DOI: 10.5194/isprs-archives-XLII-2-945-2018.

Rieke-Zapp, Dirk H., and Elisabeth Trinkl. "Face to Face: Close Range Inspection of Head Vases." International Archives of Photogrammetry, Remote Sensing and Spatial Information Sciences, 42-2/W5 (2017): 601-4, DOI: 10.5194/isprs-archives -XLII-2-W5-601-2017.

Yadong, Lie, and Gu Peihua. "Automatic Localization and Comparison for Free-Form Surface Inspection." Journal of Manufacturing Systems 25, no. 4 (2006): 251-68, DOI: 10.1016/S02786125(08)00007-1. 


\subsection{D-Vergleiche für die Oberflächeninspektion und Qualitätskontrolle im laufenden Restaurierungsprozess}

Ein weiteres Anwendungsgebiet für 3D-Oberflächenvergleiche stellen die Fachbereiche der Restaurierung/ Konservierung sowie der Restaurierungswissenschaft dar. Durch den geometrischen Vergleich zeitlich versetzt erfasster Datensätze lassen sich Aussagen zu Verformungen und den Verlauf von Verwitterungs- und Schadensprozessen eines Objektes treffen. Wird der Zeitpunkt der digitalen Abtastung mit Klimadaten (relative Luftfeuchte und Temperatur; rH, T) korreliert, erlaubt dies sogar Rückschlüsse zu klimatisch bedingten Verformungen. ${ }^{251}$ Das Verfahren kann aber auch im Sinne einer Qualitätskontrolle für die Dokumentation von Restaurierungsmaßnahmen verwendet werden. So kann der Vorzustand mit der Oberflächenbeschaffenheit nach Abschluss einer Maßnahme verglichen werden, um die Intensität eines Eingriffs und damit die Veränderung der historischen Substanz darzulegen und präzise zu dokumentieren. Hierdurch wird die verwendete Technik zu einem Werkzeug der ethischen Grundsätze fünf und sieben. ${ }^{252}$ Diese innovative Möglichkeit wird nachfolgend am Beispiel der Restaurierung polnischer Glasmalerei eingehend vertieft, wobei zudem die Möglichkeiten und Grenzen des Einsatzes von optischen Messmethoden zur Dokumentation von Glas thematisiert werden. Bislang wurde der Einsatz von SLS zur Dokumentation historischer Gläser häufig direkt ausgeschlossen, da das projizierte Lichtmuster durch das Glas hindurch zu strahlen droht, wodurch die Messungen verfälscht oder gar unmöglich werden. Dass die Dokumentation der historisch gealterten Glasoberflächen aber sehr wohl mittels SLS erfolgen kann, und dies ohne einen für das Objekt unzumutbaren Aufwand, konnte durch das Projekt deutlich herausgearbeitet werden. Die Arbeiten erfolgten im Rahmen des Forschungsprojektes „Weiterbildung von polnischen Fachkräften zur Restaurierung umweltgeschädigter Glasmalereien und nachhaltige Maßnahmen zur Rettung gefährdeter Farbverglasungen von hohem Wert", gefördert von der Deutschen Bundesstiftung Umwelt (DBU) ${ }^{253}$ und der Deutsch-Polnischen Stiftung Kulturpflege und Denkmalschutz. Das Projekt erfolgte in Kooperation zwischen der Bundesanstalt für Materialforschung und -prüfung (BAM) und dem Kompetenzzentrum für Denkmalwissenschaften und Denkmaltechnologien der Universität Bamberg (KDWT). Die Projektleitung und -koordination oblag Dr. Manfred Torge (BAM), die Durchführung und Auswertung der 3D-Dokumentation wurde vom Verfasser durchgeführt.

\footnotetext{
${ }^{251}$ So geschehen im DBU-Projekt „Wissenschaftliche Begleitung einer Maßnahme zur Präventiven Konservierung in Schloss Linderhof“, bei dessen Untersuchungen auch der Verfasser involviert war. Leider konnten die Ergebnisse noch bisher nicht umfassend veröffentlicht werden, daher sei hier auf den Abschlussbericht des Projektes verwiesen: BSV 2018, S. 7ff, S. 15ff, S. $23 f$ und S. 29.

252 Vgl. Kapitel 2.4. Ethische Grundsätze der Kulturerbeforschung: Grundsatz Nr. 5: „Jegliche Entnahme oder Veränderung von originaler Substanz muss gründlich überlegt und die tatsächliche Notwendigkeit eindeutig begründet sein." und Grundsatz Nr. 7: „Alle Maßnahmen an einem Kulturerbe sollen ausführlich dokumentiert und angemessen veröffentlicht werden." S. 19.

253 DBU-Aktenzeichen 33822/01.
} 


\section{Publikation 4: 3D Inspection of the Restoration and Conservation of Stained Glass Windows using High Resolution Structured Light Scanning (Rahrig/Torge 2019)}

Der Artikel ist hier als Post-Print in einem angepassten Layout wiedergegeben. Für eine korrekte Zitierweise und Seitenzahlen bitte die Originalquelle verwenden:

Rahrig, M. / Torge, M.: „3D Inspection of the restoration and conservation of Stained Glass Windows using high resolution Structured Light Scanning." In: Int. Arch. Photogramm. Remote Sens. Spatial Inf. Sci., XLII-2/W15, 2019, S. 965-972, Doi: https://doi.org/10.5194/isprs-archives-XLII-2-W15-965-2019.

(peer reviewed Journal)

\section{Abstract:}

The initial focus of this research was on the development of a general workflow for the documentation and monitoring of historical stained glass windows using structured light scanning. Therefore windows from different churches, time periods and with different corrosion and damage phenomena were scanned before and after conservation measures. To evaluate the execution of the restoration measures the data was compared using 3D inspection software to examine the differences in geometry between the two scans. Various problems had to be solved, for example, how to deal with heavily reflective surfaces and the extreme contrast between light and dark surfaces, as seen in the borders between 'Schwarzlot' painting and plain glass. The application of materials for matting the surfaces, such as Cyclododecane spray, was impossible due to the high accuracy of the surface measurement required for 3D inspection. Regarding the contrast differences of the surfaces, the creation of exposure fusions and the use of polarization filters to reduce reflections were tested. In addition to the general problems encountered when recording translucent surfaces, the historical glasses caused additional problems in calculating surface comparisons. For example, the windows have to be moved and turned around several times, both during the conservation process and while scanning, causing deformations of the geometry due to the flexible lead rods allowing a certain degree of movement.

\section{Introduction}

As part of a research project for the training and qualification of Polish specialists in the restoration of glass paintings, funded by the 'German Federal Environmental Foundation' (DBU) and the 'DeutschPolnische Stiftung Kulturpflege und Denkmalschutz' (DPS) with funds from the Federal Republic of Germany, and in cooperation with the 'Bundesanstalt für Materialforschung und -prüfung' (BAM) and the KDWT/ University of Bamberg, high-resolution 3D documentation was used to evaluate the execution of the restoration measures. For this purpose, historical stained glass windows were recorded using structured light scanning (SLS) before and after the conservation treatment. The data was then analysed using 3D inspection software in order to examine the differences in geometry between the two scanning campaigns. 
The windows are from three churches in Poland, and different time periods; the medieval ones are located in Koszewko, the glasses from the early $20^{\text {th }}$ century in Legnica, and the glasses from Oswiecim date back to the mid- $20^{\text {th }}$ century. They all exhibit different corrosion and damage phenomena.

\subsection{The windows from Koszewko}

In the village church of Koszewko, stained glass paintings showing the coats of arms of the 'von Küssow' family, dating back to the $15^{\text {th }}$ century, have been preserved (Fig 1). They display environmental corrosion damage and loss of the painting layer as well as glass breakage and defects in the lead rods. In the course of their restoration, areas with darkening were brightened by manual cleaning. The brightening process causes particular difficulties in the 3D recording after restoration, as it leads to increased reflection.

\subsection{The windows from Legnica}

The windows from the Liebfrauenkirche in Legnica (Fig 1) have high-quality glass paintings dating from 1905/6. They were manufactured in various well-known German glass workshops: Franke, Naumburg; Müller, Quedlinburg; Geiges, Freiburg; Oetken, Oldenburg; Linnemann, Frankfurt/M. Due to the lack of protective glazing, the 'Schwarzlot' paintings are at risk and suffer particularly from flaking. 'Schwarzlot' is the colour used for stained glass and consists of glass particles and metal compounds burnt into the glass surface after application (Brepohl, 2013). Therefore the main focus of the conservation was a careful cleaning of the glasses and consolidation of the paintings. The 3D inspection was carried out to determine whether the removal of the dirt layers is measurable.

\subsection{The windows from Oswiecim}

The stained glass windows in the parish church of Oswiecim (Fig 1) date back to 1940. They were produced by Müller, Quedlinburg. Due to thermal stress, presumably caused by fire, the glass has a very strong craquelé, many cracks and flaws, and the paint is deteriorating. During conservation, the complex crack pattern was strengthened with acrylic, and the 3D inspection was used to check whether the acrylic resin is only inside the cracks or has been additionally deposited as a layer on the surface. 

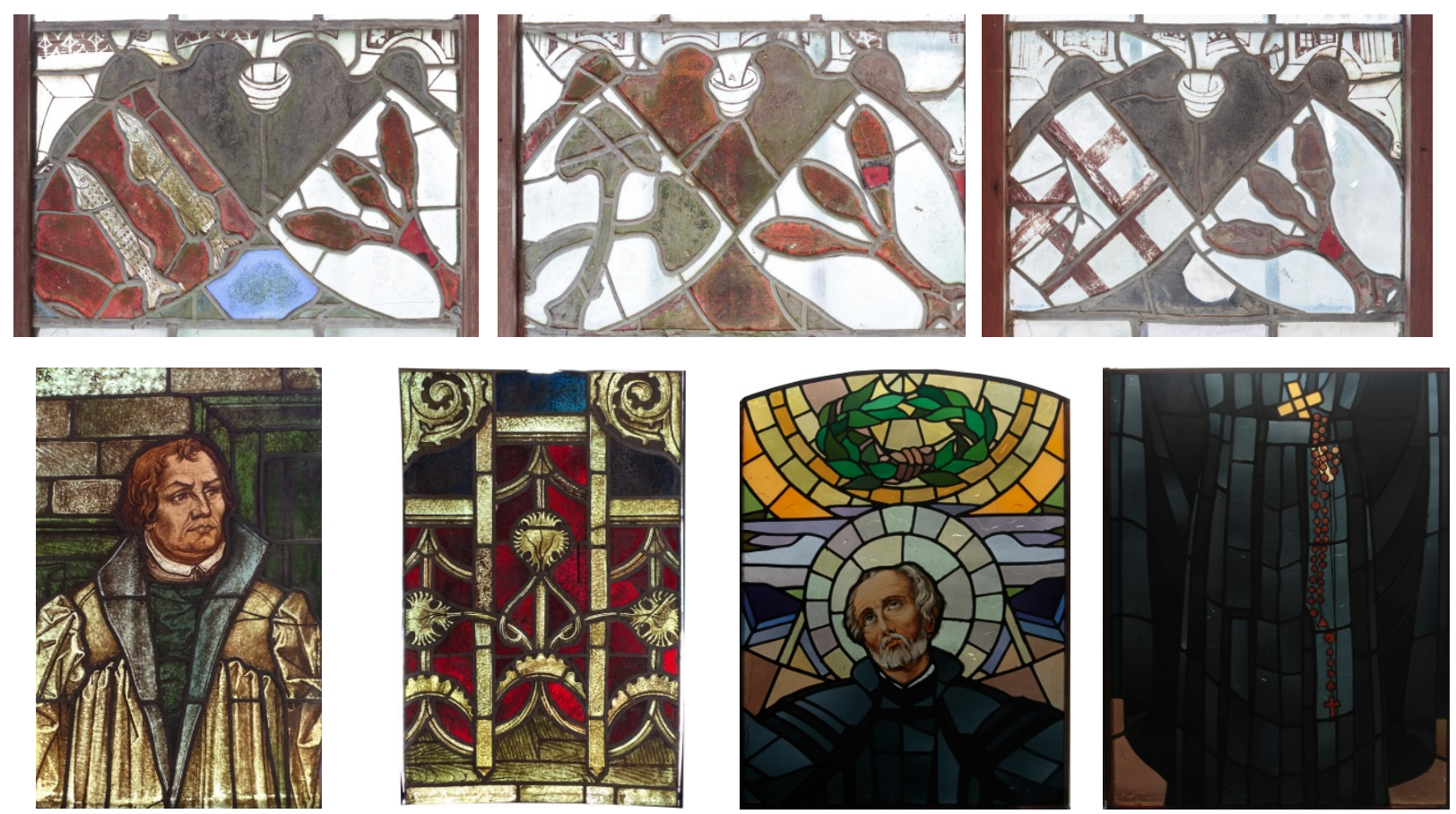

Figure 1. Overview of the Polish stained glass windows. In the upper line from left to right: Koszewko $n I I, n I I I$, sIII. In the bottom line from left to right: Legnica $n \times 3 b, n \times 4 b$ and Oswiecim $3 b$ and $2 b$.

(Oleszczuk 2017-2019)

\section{Technical Background}

The three-dimensional measurement of glass surfaces is a relatively complex problem. Common sensors used for non-contact measurement of surfaces are based predominantly on two basic techniques; active and passive systems. Active sensors include techniques that apply an impulse to the surface to be documented and then detect its reflection. The impulse can be a laser beam or a light pattern, so this category includes both laser and structured light scanners. In passive systems, the surface is not stimulated; the sensors detect the surface on the basis of shape from shading, shape from motion and comparable methods. Passive systems include, for example, stereo cameras, but also the calculation of image groups from individual images; both based on Structure from Motion (SfM) and Image based Modeling (IbM). In both cases, the surface of the object to be documented must be defined clearly, i.e. it should be opaque and not translucent (Stylianidis et al., 2016).

Glass, on the other hand, is characterised by its optical properties as a translucent material. Due to its translucency, the glass surface is difficult to capture optically, which considerably impairs the common systems used for 3D measurement. Over the past several years, various systems have been developed to solve this problem (Eren, 2010; Ihrke et al., 2010; Yeung, 2011; Mériaudeau et al., 2012). These are, for example, processes that stimulate the surface thermally or with UV light (Rantson et al., 2010), while other systems make use of the light refraction properties of the glass object in a bath of fluorescent liquid (Hullin et al., 2008). All these procedures share two fundamental problems. The devices are usually custom-made or prototypes and therefore not freely available on the market, and 
they have extremely limited usability in the context of the documentation of cultural heritage. It is usually impossible to either thermally stimulate fragile historical objects, or immerse them in liquid.

In various projects undertaken in the field of preservation sciences at the University of Bamberg, it has been observed that corrosion phenomena alter the optical properties of historical glass paintings in a way that is detectable using high-resolution, three-dimensional measurement with conventional structured light scanners (Drewello, Kleine et al., 2010; Drewello, Wetter et al., 2010; Drewello, Kleine et al., 2016). Due to the centuries of exposure to environmental phenomena weathering crusts, lime, gypsum and dust deposits form on the windows, result in a wafer-thin, opaque layer on the surface. This layer can be used to measure the surface with optical systems. Salemi et al. achieved similar results using a Konica Minolta Laser Scanner (Salemi et al., 2008).

In structured light scanning, a projector transmits a pattern of light onto the surface to be measured; the deformation of the pattern on the surface is then captured by a camera. In this way, 3D coordinates can be calculated (Rahrig et al., 2018; Gühring, 2002; Akce, 2007; Floth et al., 2011). The scanner manufacturers generally recommend that the scanner is placed as straight as possible, orthogonal to the surface to be measured - this ensures that the largest possible area can be captured within a single scan, and the surface reflects the light of the projector optimally to the camera. In this way opaque surfaces can be captured with comparatively short exposure times for single scans. In the case of glass surfaces, however, this setup is problematic; strongly reflecting spots are created, leading to an overexposure of the scan and thus holes in the data. If, however, the scanner is placed at an angle between $80^{\circ}$ and $45^{\circ}$ to the surface to be documented, the highlights and specular reflections are not reflected directly into the camera, avoiding overexposure. The drawback with this setup is that the whole field of view of the scanner is not used optimally and therefore the area recorded is a little smaller. However, the data recorded in this area are more homogeneous so the overlaps between individual scans can be reduced and fewer additional scans are needed to fill holes caused by reflective hotspots.

Another problem is that the heterogeneous thickness and colour of the corrosion and dirt deposits adjacent to non-corroded surfaces, as well as glossy lead rods and both dark and light 'Schwarzlot' paintings, require very different exposure settings in order to document the glass as completely as possible. Dark areas require longer exposure times, bright surfaces shorter. Therefore a combined scan of the glass surface with different exposure settings can be helpful. With the device used, the Comet L3D from Steinbichler, it is possible to create a so-called exposure fusion analogous to an HDR photo. Here, two or three recordings with different exposure settings are merged into one single scan, which thus contains better surface information over the entire area captured. 


\subsection{Cyclododecane for matting the glass surface}

The use of matting sprays, which are frequently used in industry for scanning glossy surfaces, is problematic in the field of heritage preservation. In general the components of the sprays are not fully known and thus potentially contain solvents which could react negatively with the historical objects and materials. In addition, in order to remove the sprays after scanning, a mechanical cleaning of the surfaces is required; which could lead to additional damage. Only Cyclododecane, a volatile binder that has long been used by restorers for temporary consolidation, can be used as a matting spray (DíazMarín et al., 2015). As it sublimates residue-free within a few hours, no mechanical cleaning is necessary and, with the exception of some modern plastics, it does not react with materials. Cyclododecan has been used at the University of Bamberg for matting surfaces since 2005 (Bellendorf, 2007). However, experience has shown that the available sprays do not usually apply a uniformly thin film, but tend to form (small) lumps. The use of Cyclododecane had to be dispensed with in the case of the stained glasses documented here as the uneven distribution and layer thickness would falsify the results of the 3D comparison of the condition before and after the cleaning and preservation measures.

\subsection{Polarization filters to reduce reflections}

Compared to the glass paintings from Koszewko, Straubing (Drewello, Kleine et al., 2010 and 2016) and Erfurt (Drewello, Wetter et al., 2010), the glasses from Legnica and Oswiecim are relatively young, dating back only as far as the beginning and first half of the $20^{\text {th }}$ century. Due to technical developments and advancing industrialisation, the raw materials for glass production were much purer by that time, making it possible to produce higher quality and more stable glasses (Wedepohl, 2003). In addition, these glasses have been exposed to the weather for a far shorter time than the medieval examples. Thus these glasses are in a better condition; their luminosity is more intense, but the corrosion crusts on the surfaces are less pronounced. Therefore, scanning was expected to produce significantly stronger reflections. In order to reduce the mirror effects of these young stained glasses, the use of polarization filters was tested.

Light sources such as LED, light bulbs and even the sun emit light rays in disordered waves. When these light rays are reflected by a surface, for example water, the beam is fanned out and emitted in different directions as scattered light. Polarising filters have the property of only allowing light with a single wave orientation to pass through, with other wave orientations being blocked (Chen et al., 2007). Three setups were tested for the documentation of the stained glasses: A polarising filter in front of either the projector or camera, and a combination of both. The filter in front of the projector should reduce the reflections on the glass surface, while the filter in front of the camera should filter the light to the sensor, reducing the scattered light reflected by the glass surface. Chen et al. has already shown 
the possibilities of polarising filters for scanning translucent objects and has achieved good results for marble, fruits and a modern glass vase (Chen et al., 2007).

The empirical studies in this project, using filters to scan the glass paintings were unfortunately not that successful. With the use of two polarising filters, one in front of the projector and one in front of the camera, not enough light was transmitted to the image sensor using either crossed or parallel filters, making data acquisition impossible. Using a single polarising filter in front of the projector or in front of the camera produced similar results. In both cases the reflections were reduced, but the filters blocked too much light. Thus, the exposure time and light intensity of the projector had to be increased to a degree impossible with the highest possible light settings supported by the scanner used (Fig 2). The best results for scanning the glass surfaces were therefore achieved without any filters, and with the scanner positioned at an angle of $80^{\circ}$ to $45^{\circ}$ to the object.
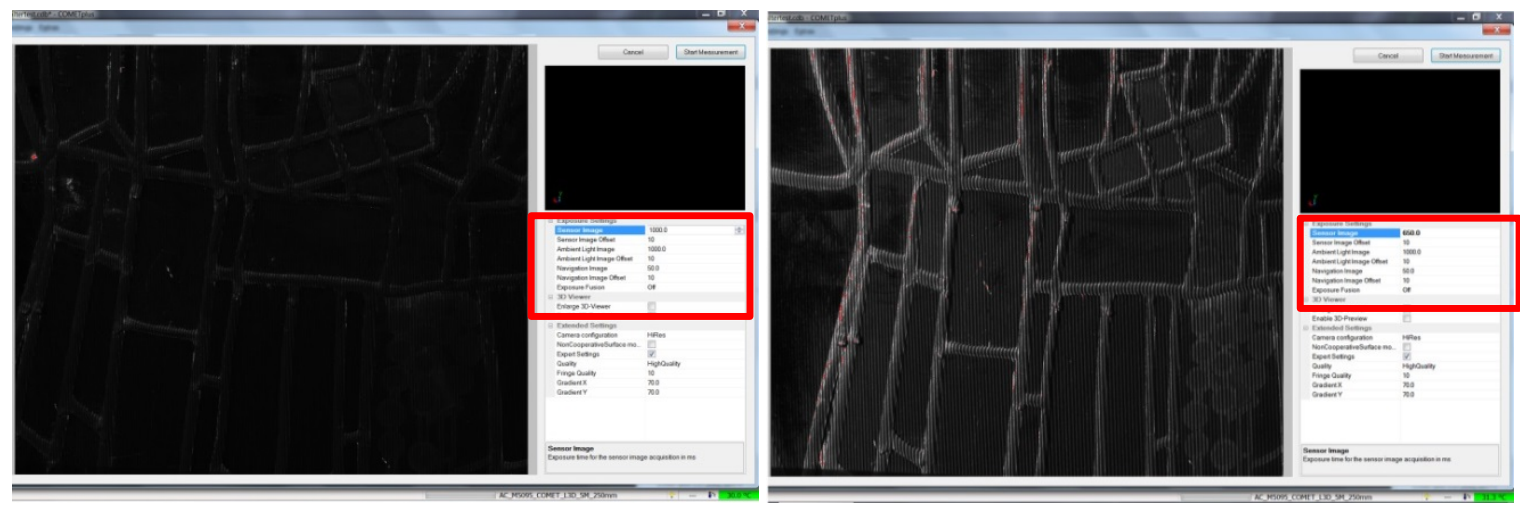

Figure 2. Oswiecim 2b; Comparison of different light setups, within the scanner software, with and without the use of polarising filters. Left part: Setup with filter; highest possible light settings don't provide enough light for scanning. Right part: without filter, but scanner located $70^{\circ}$ to surface; ideal light settings.

\subsection{Data processing}

The aim of the 3D documentation of the stained glass paintings was a comparison of the surfaces before and after the restoration. The very small differences between the two measured surfaces required the data to be analysed extremely carefully. For example, the structured light scanner was calibrated according to the manufacturer's specifications at regular intervals and after every transport and change of lenses. After completion of the measurements, an iterative-closest point matching (ICP/'best-fit') between individual scans was carried out to ensure the best possible alignment. Once the point cloud scans were converted into a surface model, the resolution of the mesh was adapted to the resolution of the lenses used; $100 \mu \mathrm{m}$ for the $250 \mathrm{~mm}$ lens which captured both the front and back of the windows in their entirety; and $45 \mu \mathrm{m}$ for the $75 \mathrm{~mm}$ lens used for partial areas of a few individual glass panes per window. 
The data sets were neither smoothed nor were holes interpolated and closed. If some individual glass panes had particularly strong reflections, it was checked during post-processing whether the glass surface had been captured adequately, or whether the data was noisy, and the noisy areas were removed manually. The overview of the windows is therefore partially incomplete, but this is preferable to inserting interpolated data which would falsify the surface comparisons. The postprocessing of the data was carried out using the COMETplus v.9.91 software by Steinbichler, and Geomagic Wrap 2017. The data were saved as STL-files and imported into GOM Inspect 2018 for the calculation of the $3 \mathrm{D}$ comparisons.

\section{General Results of the single campaigns}

The high-resolution documentation of stained glasses in individual campaigns has already shown potential in providing informative surface observations. As already demonstrated by Drewello, Kleine et al. with the example of the medieval Moses window at St Jacob in Straubing, the stained glass can be recorded accurately with the help of structured light scanning. Due to the difference in topography, not only can 'Schwarzlot'-painting be separated from the glass surface, but statements on the painting technique can also be made. For example scanning can reveal which tools were used to apply the 'Schwarzlot' or how luminous accents were set. Furthermore the 3D surface documentation can help in the reconstruction and retouching of faded areas (Drewello, Kleine et al., 2010 and 2016).

'Schwarzlot' is a colour that has been used for glass painting since the Middle Ages. It consists of a mixture of finely ground glass powder, carbon, metal and a variety of other components. The viscous paint is applied to the glass panes, and can be drawn on using brushes, or as a thin layer with highlights and details scratched in using soft tools such as wooden sticks. After drying, the glasses are heated, whereby the glass particles of the 'Schwarzlot' form a stable and long-lasting bond with the glass surface (Brepohl, 2012). 


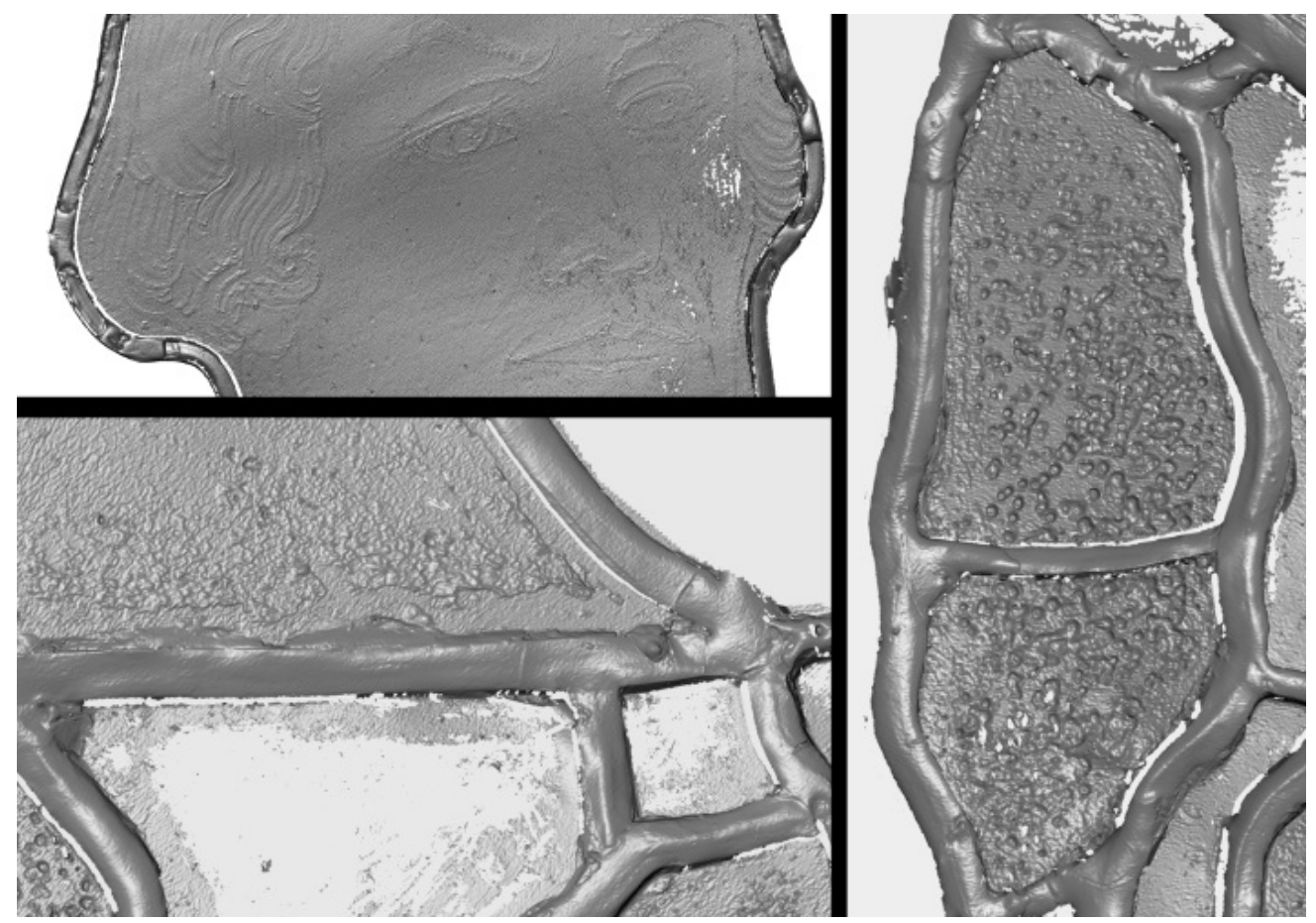

Figure 3. Overview of different surface details visible in the 3D scan; top left: 'Schwarzlot' painting of a face; bottom left: dust and dirt layers on the glass surface, next to clean glass panes; right: strongly corroded glass pane with a repair lead rod in the middle.

The paintings of the stained-glass windows in Koszewko and Legnica are perfectly visible in the 3D model (Fig 3, top left). Further surface information can be found in the 3D models, for example the effects of different corrosion phenomena. These can be weathering crusts and dust and dirt layers that are deposited on the glass surface (Fig 3, bottom left), but also corrosions that decompose the glass surface piece by piece and leave a craterlike landscape in the glass (Fig 3, right). Cracks in the glass and historical repairs, such as those using lead rods, can also be detected (Fig 3, right). Area in which the glass surface is in an excellent condition, are represented in the 3D scan as negative findings, without surface information (Fig 3, down left). Due to the lack of weathering crusts and other deposits, this glass is not opaque but still completely translucent, making measurement of the surface impossible.

\section{3D inspections}

\subsection{D Inspections of the whole window}

The main aim for the 3D documentation of the historical stained glasses was to compare the surfaces before and after conservation. An initial juxtaposition of the two data sets for a visual comparison provides at first only limited information. It can be seen clearly that in some areas the cleaning of the surfaces has significantly increased the light transmittance, and that the scans from after the conservation have relatively more holes or missing parts due to areas that cannot be scanned (Fig 4). However, further differences between the two campaigns can be detected only to a very limited extent in this way. A mathematical comparison of the models by means of 3D inspection software is therefore used to objectively record changes. 

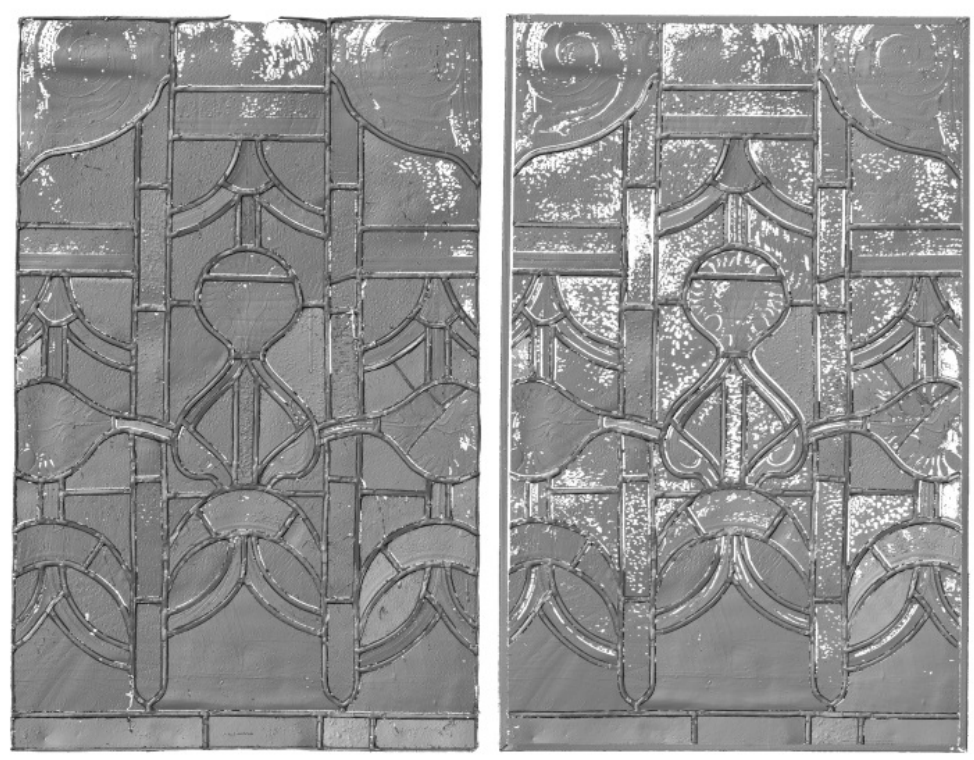

Figure 4. Juxtaposition of window $n \times 4 b$ from Koszewko before (left) and after the conservation (right).

GOMinspect 2018 software was used to calculate the comparisons. For this purpose, the STL data of the initial state was loaded as the reference model and the second model from after conservation and cleaning as the so-called actual model. In these comparisons, the geometric differences between the two 3D models are visualised in a false colour image. Blue areas show shrinkage of the surface and yellow and red areas an increase (Fig 5).

Due to the work processes in the conservation environment, it was not possible to set up a static reference system for the orientation of the scans between the different campaigns; the glasses had to be turned around several times during their conservation in order to work on the front and back sides. Additionally both sides were documented photographically on multiple occassions. Due to these many transports and movements within the restoration workshop, the 3D models of the glasses had to be aligned to each other digitally by means of an iterative-closest point (ICP) or 'best-fit' method. The glasses were first aligned roughly by hand using a three-point pre-alignment, after which the ICP could be calculated.

The standard deviation of the scans using the $250 \mathrm{~mm}$ lens in a resolution of $0.1 \mathrm{~mm}$ is disproportionately large after alignment, on average about $0.8 \mathrm{~mm}$. A closer look into the surface comparison shows the reason for this (Fig 5). The large deviations between the 3D data from the initial condition and after conservation do not result from the conservation measures themselves, but rather from the freedom of movement of the lead rods. Since lead is not a rigid metal but soft, slight movements of the lead rods occur during the handling of the windows. The middle part of the glass in particular tends to sag slightly, which leads to bowl-shaped deviations in the 3D comparison. Similar effects have already been experienced with the medieval windows from Erfurt (Drewello, Wetter et 
al., 2010). For the 3D comparisons, this movement is counterproductive, but for the historical glass windows it is an important protective factor. This flexibility, for example, compensates for wind or storm gusts which can press against the windows, thus preventing the individual glass panes from breaking.

Nevertheless, certain changes, for example the reinforcements on the edges of the stained glass windows, can be seen in the overall view of the panes, Here, copper sheet frames were placed around the windows during conservation to give them more stability, making it easier to reinstall them in the church. Changes in the lead net can also be recorded (Fig 5). These may be areas where lead rods were exchanged, i.e. where new rods were added. However, there are also places where lead rods used for repair have been removed, as cracked glasses that were secured with a lead rod during a previous historical restoration were now glued during the modern restoration.

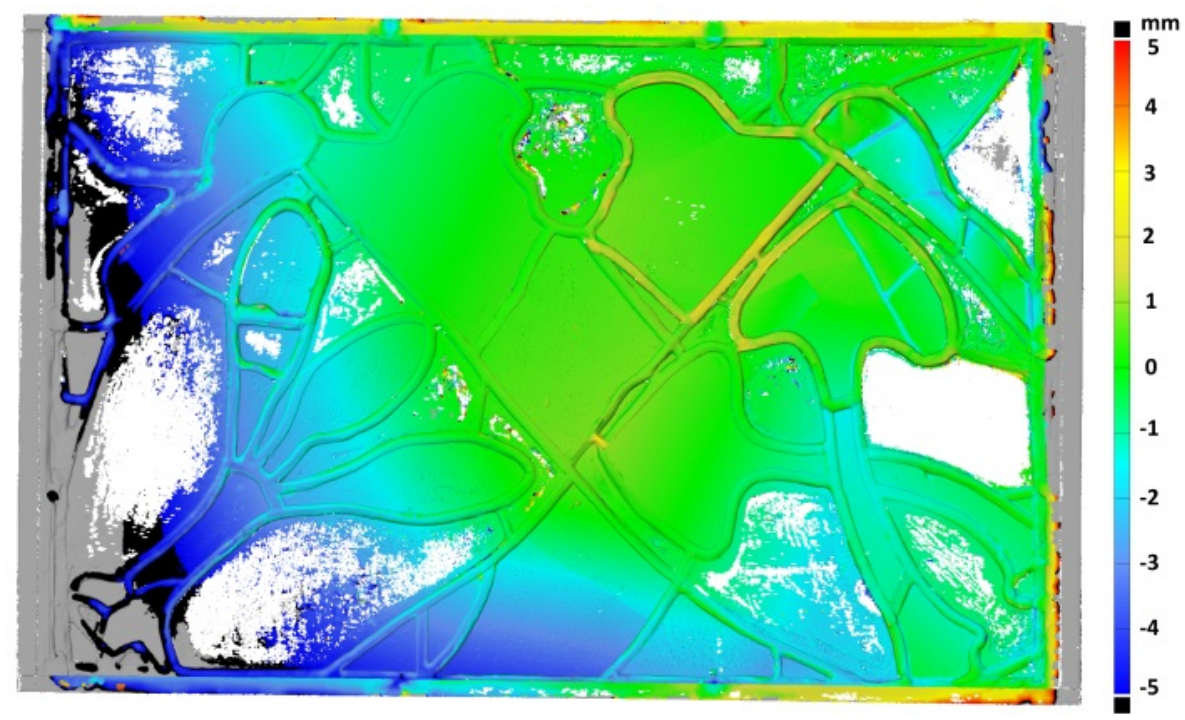

Figure 5. 3D inspection of the outside of the stained glass window nIII from Koszewko before and after its conservation.

\subsection{D inspections of single glass panes}

Since the corrosion layers are thin on the historical glass surface, in addition to the scans of the entire windows, single individual glass panes were documented with a higher resolution. A $75 \mathrm{~mm}$ lens with a resolution up to $45 \mu \mathrm{m}$ was used for this purpose. This lens captures a much smaller area per single scan than the $250 \mathrm{~mm}$ lens, with a field of view of about $5 \times 8 \mathrm{~cm}$, compared to $18 \times 25 \mathrm{~cm}$ with the $250 \mathrm{~mm}$ lens. With a constant image sensor of 5 megapixels inside the scanner, the surface resolution increases from 100 to $45 \mu \mathrm{m}$. For each church and documentation campaign, a selection of individual glass panes to be documented was made in consultation with the restorers. Glass panes were selected specifically to show representative damage phenomena for the respective windows. During scanning the surrounding lead rods were also recorded in order to detect changes both on the glass surface and on the rods themselves. 
The scans were processed in the same way as the scans of the entire windows, and the alignment of the scans in GOMinspect 2018 also carried out using ICP. However, only the surface of the glass, without lead rods, was used to calculate the alignment. This selection-based alignment serves to calculate the 3D comparisons much more exactly, as it ignores the movement of the lead rods.

The restoration measures for the Polish glasses were not carried out as a comprehensive removal of entire layers; instead, individual measures were taken at corroded areas. It was therefore expected that the geometry of a single glass pane would not change significantly. Deviations and falsifications of the 3D comparisons due to slippage of the individual glass panes between movable lead rods are also counteracted by the selection-based 'best-fit'. The standard deviation for the alignment of the scans between the two campaigns was thus about $0.05 \mathrm{~mm}$ on average.

\subsubsection{Koszewko}

Information regarding several different conservation measures can be captured in the high-resolution $3 D$ inspection of the individual glass panes. Figure 6 shows the 3D comparison of the inside and outside of a single pane from a coat of arms representation from window $\mathrm{nll}$ from Koszewko. The pane shows one of the two fish (pikes) from the coat of arms. Since the glass pane was broken in the middle, the alignment was only calculated on the front part of the fish, and. five conservation treatments can be clearly identified. When looking at the outside surface, it can be seen that the left part shows extreme changes. They extend from more than $-1 \mathrm{~mm}$ in the lower area of the glass pane up to $+0.6 \mathrm{~mm}$ in the upper area. Here, it is clear that movement of one of the glass panes took place. The movement can be traced back to the gluing of the two divided glass panes together. After conservation, they form a uniform plane surface.

It was necessary to first remove the two glass pieces in order to glue them together. To do this, the lead rods had to be carefully removed, resulting in deformations. The lower rod was merely bent up, resulting in changes of up to $+/-1 \mathrm{~mm}$ in the shape of the lead. The upper rod, on the other hand, was replaced, resulting in significantly greater changes in the surface.

The comparison of the inner side of the window also shows a significant change in the transition between the two partial glasses. During the restoration a repair lead that was no longer necessary, was removed after the glass panes were reassembled. 


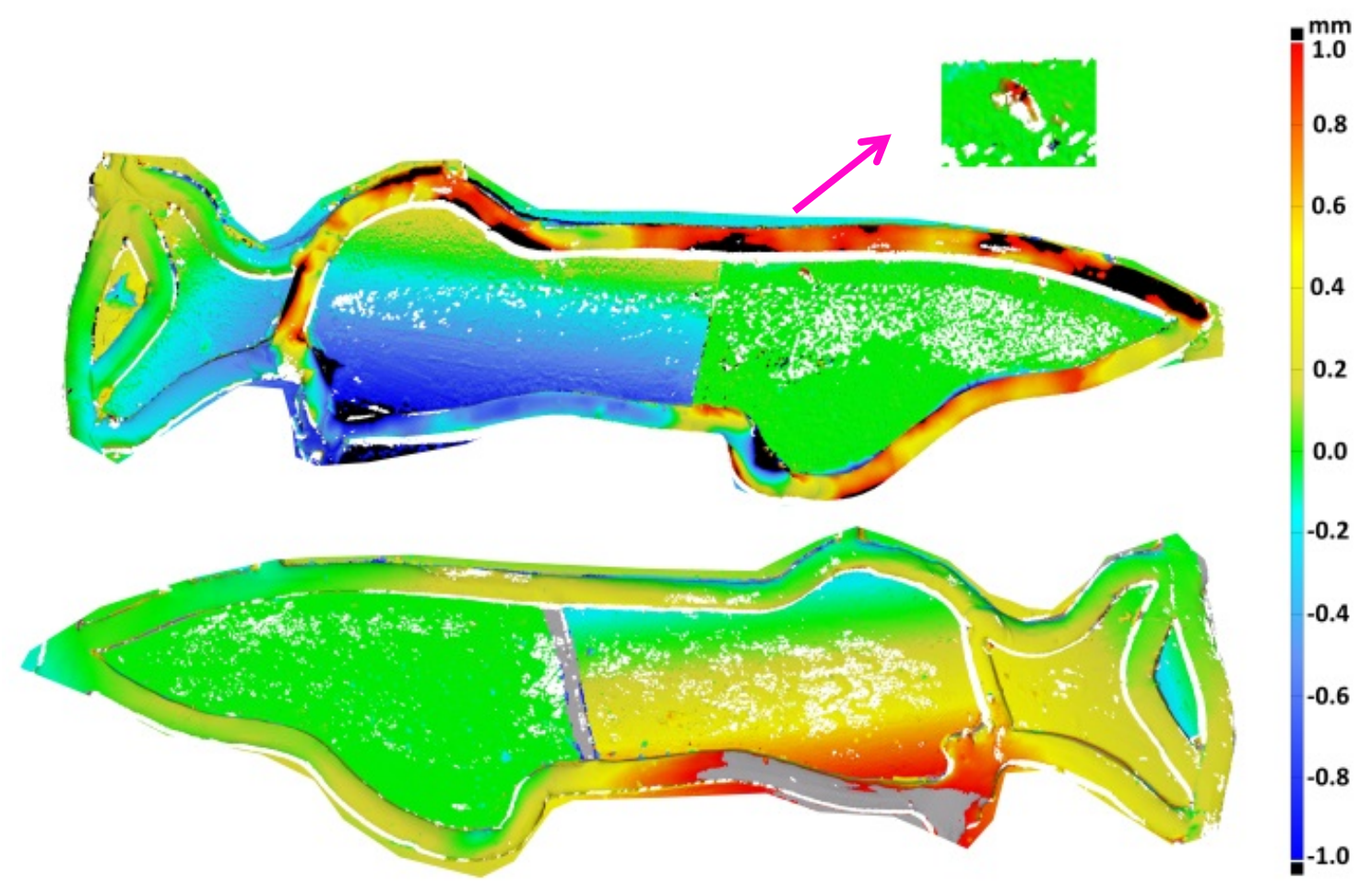

Figure 6. 3D inspection of a single glass pane from $n l l$, Koszewko. Top: comparison of the outside; bottom: comparison of the inside.

Another anomaly on the surface can be detected: On the right part of the glass pane (Fig 6, detail), near the upper lead rod, there is an area in which an increase of the surface compared to the initial state is visible. This is most likely leftover window putty. After the glass pane had been reassembled and inserted into the lead net, the space between the glass pane and the lead rod was filled up with putty, creating a stronger connection between the glass and the surrounding leads, thereby increasing the stability of the windows. This also prevents the individual glass panes from slipping and falling out.

The white areas are areas that could not be scanned during the second campaign. Here, after conservation, the light transmission of the glass was too strong to allow the detection of the surface.

In another single glass pane it can be clearly seen how carefully and cautiously the conservation was carried out. When looking at the entire pane, hardly any changes are noticeable, so a part of the image has been enlarged (Fig 7). The partial area shows a section from the outside of the window. Logically, the exterior areas are more exposed to the weather, which is why stronger corrosion products are to be assumed. The detail shows the surface of the glass with various small structures. These are the edges of the weathering crust. The $3 \mathrm{D}$ inspection shows that only a very few loose areas of the crust have been removed. The other areas seem to have a stable connection with the glass, so that an overall removal of the corrosion layer was not necessary and might have damaged the glass. The black areas are due to small holes in the initial condition scan, and in the left corner of the detail, a small particle of window putty is again visible. 


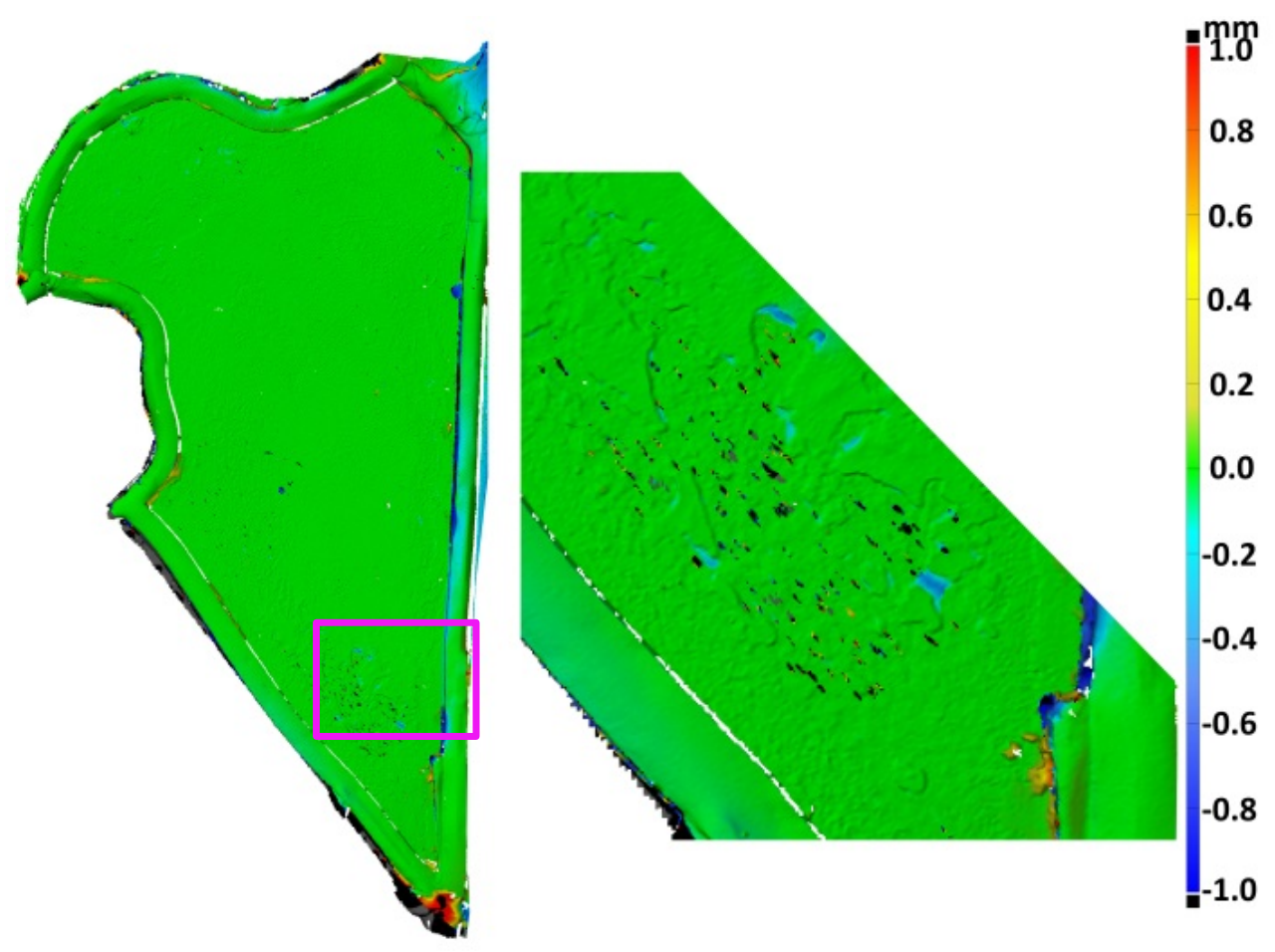

Figure 7. Overview and detail of the 3D inspection of a single glass pane from $n I l$, Koszewko.

The window $n$ III from Koszewko was in a poor condition before conservation (Fig 5). Various glass panes were broken, and some fractures were already fixed by repair leads. In the course of conservation, the repair lead was removed and, as the detail section shows (Fig 8), the highly fragmented panes were reunited with great care. No residues of the adhesive are visible on the glass surfaces, demonstrating that the acrylic resin (Araldit $2020^{\odot}$ ) was applied very carefully to the edges of the fractured fragments without running over the surfaces.

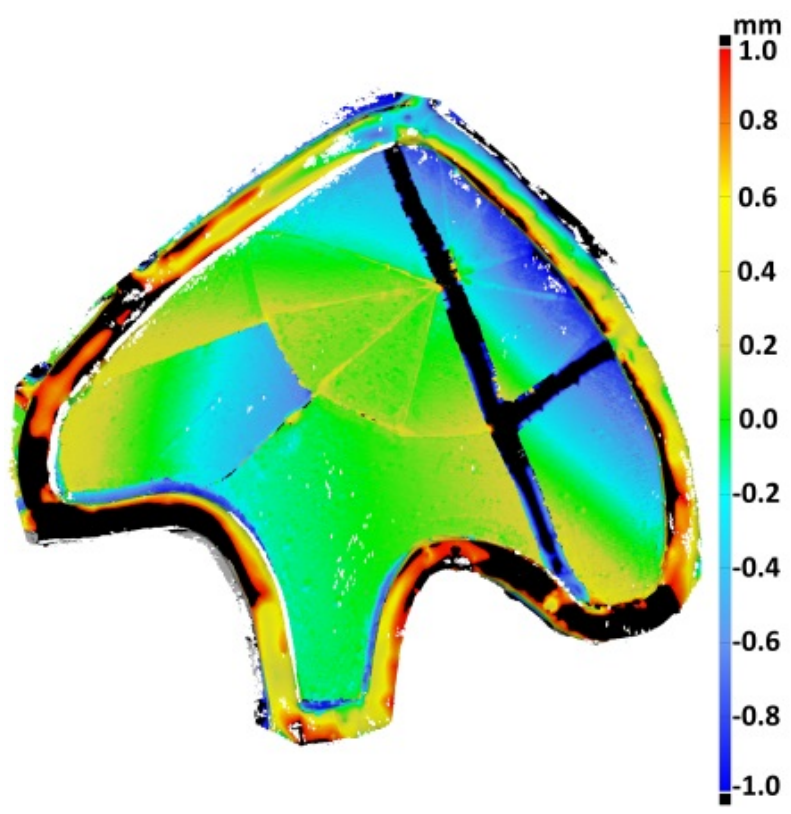

Figure 8. 3D inspection of $n I I I$, Koszewko, showing the restoration of strongly fragmented glass panes. 


\subsubsection{Legnica}

The surface comparison of the inside of the portrait of Martin Luther in window $n \times 3 b$ of the church of Legnica shows no measurable changes (Fig 9). Here the 'Schwarzlot' painting was consolidated, and the works left no residue on the surface. The scans of a single campaign clearly reveal the filigree line drawings of the face (Fig 3, top left). In comparison to the transmitted light photo, strong brightness gradients in the glass are visible, but it is only one single glass pane and not a composition of several different coloured panes. These colour differences are instead due to different glass thicknesses. On the reverse side a clear step can be seen in the glass (Fig 10). Here, during the production of the glass painting, a part of the surface was etched off, resulting in a different refraction behavior of the glass.

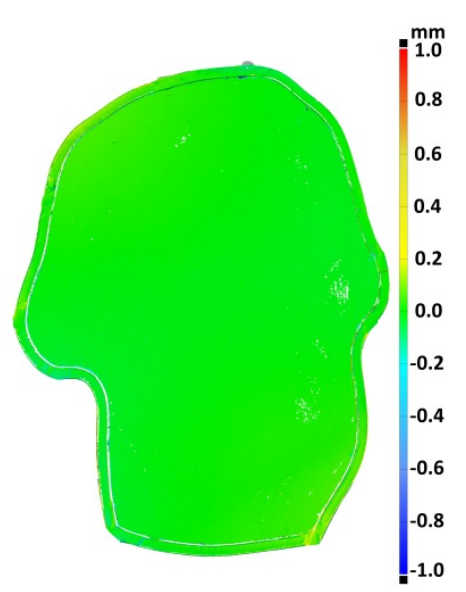

Figure 9. 3D inspection of a glass pane of $n X I 3 b$ from Legnica.
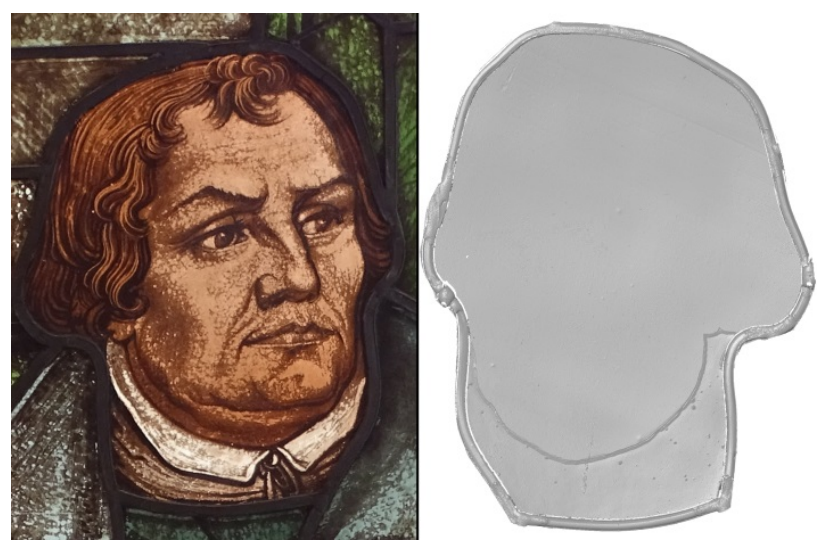

Figure 10. Left: transmitted light image of the glass pane from $n X I 3 b$ (Oleszczuk 2019). Right: view of the outside (3D scan).

\subsubsection{Oswiecim}

In the 3D scans of the Oswiecim windows, the extreme damages of the craqueled glass panes are clearly visible in the overall view (Fig 11, 12). The cracks are spread chaotically through the panes, but the representation of the inner side with the various missing parts in the scan also shows that the glasses are otherwise in a relatively good condition. They are much more translucent than the medieval windows from Koszewko. 


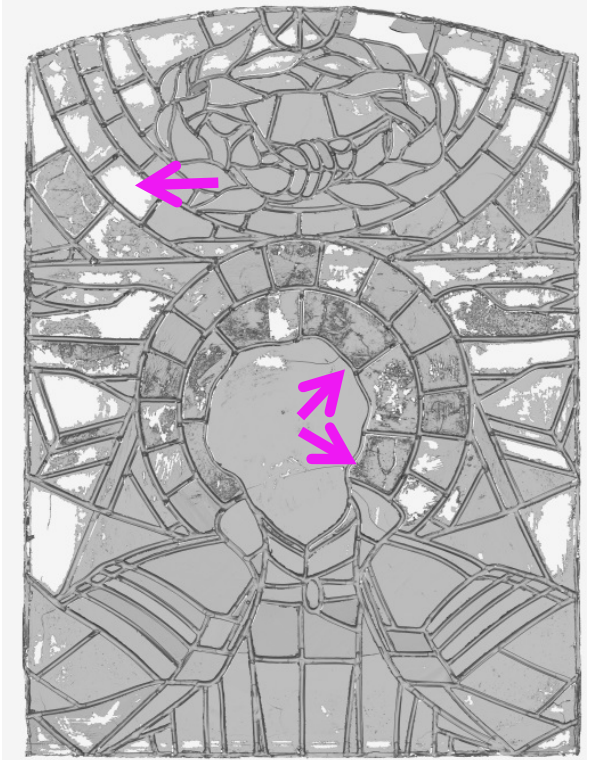

Figure 11. Overview of window $3 b$ from Oswiecim before conservation (inside). Some cracks are marked pink.

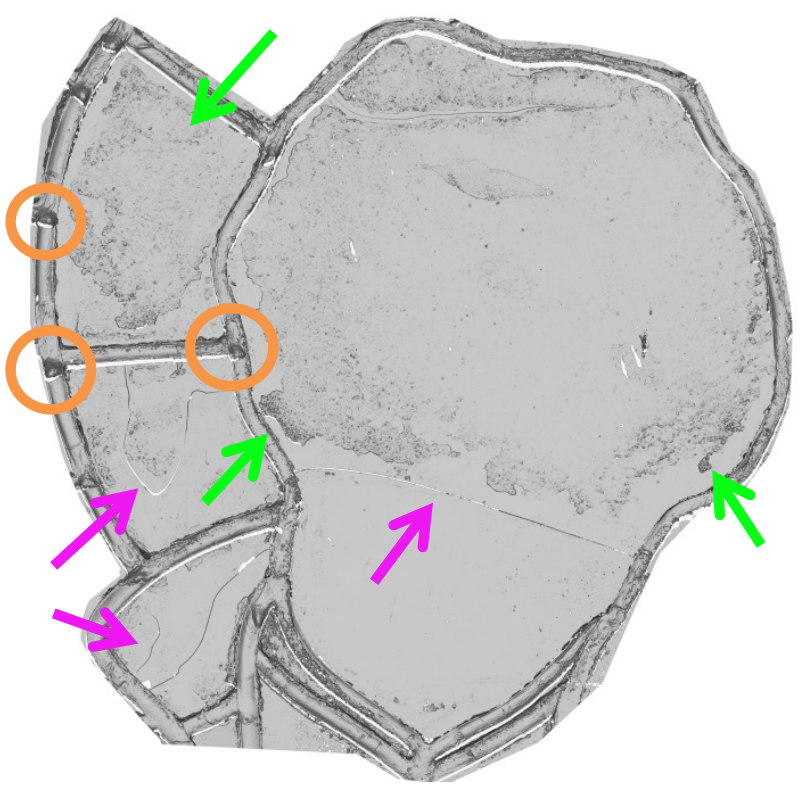

Figure 12. Detail of window $2 b$ from Oswiecim (outside). Orange: The solder drops caused strong heat; Green: the thin lime slurry; pink: craqueled glass panes

The detailed examination of the high-resolution scans provides further information on the reason for the cracks. At the junctions between the individual lead rods, drops of solder are located on both the inside and outside (Fig 12). The drops are all on the lower edge of the solder joints, and therefore seem to have formed only when the windows were already installed upright in the church. If the droplets had instead formed when the stained glasses were leaded in the glazier's workshop, there would have to be differently oriented droplets as the windows would have been processed lying horizontally on a table. It can therefore be assumed that the windows were exposed to a strong source of heat at some point during their time in the church, presumably from a fire. However, no fire is recorded in the church itself since the glass was installed in the 1940s and therefore it is possible that it must instead have taken place outside, in the immediate vicinity of the windows.

On the outside of the Oswiecim windows, extremely uneven structures are clearly visible in the 3D scan (Fig 11). Analysis has shown that this is gypsum slurry applied over large areas of the windows, leading to strong darkening of the glass. During restoration, this lime layer has to be removed in order to restore the original luminosity of the glasses. Unfortunately, the documentation of the conservation is still pending, which is why no 3D inspection of the Oswiecim windows can be presented here.

\section{Conclusion}

Within the research project it was shown that the three-dimensional documentation of historical (painted) stained glass windows with a commercial structured light scanner is possible. Scanning can be done without any special constructions, modifications of the scanner or coating of the historical 
objects. The high-resolution observation of the glass can provide useful information regarding the production of the glass painting and on damage and corrosion phenomena.

Large-scale calculation of 3D surface comparisons of historical stained glass before and after conservation, or for monitoring of weathering is, however, problematic, as the flexible lead net offers too much scope for movement. When installed in the churches, this freedom of movement is required as a shock absorber against strong wind loads, and during work in conservation workshops, free access to the front and rear sides of the windows must be ensured for a smooth workflow. For these practical reasons, it is therefore not possible to install a fixed referencing system on the windows.

Therefore, only extreme changes or interventions can be detected in the comparisons of the entire windows. For example, changes in the lead rods and auxiliary constructions such as reinforcements at the edges of the windows can be detected. In addition, the change in the light transmission behavior of the glass can be measured.

Observations of 3D inspections of single glass panes, however, provide impressive results, revealing details about the conservation process. Here, not only small changes to the lead rods, but also the careful restoration measures conducted on the glass surfaces can be documented in high resolution. The removal of corrosion products, the bonding of cracks as well as traces of window putty from fixing the individual panes in the lead net can be recorded.

Since the 3D measurement and calculation of surface comparisons in the context of the conservation of historical stained glass is comparatively complex, it can be assumed that such documentation is not applicable to the entirety of a medieval church's windows. Rather, this method should be carried out specifically on individual, representative windows in order to provide meaningful results for monitoring surface changes and, if necessary, for random quality control of conservation measures.

\section{Acknowledgements}

Our special thanks go to the 'German Federal Environmental Foundation' (DBU) and the 'DeutschPolnische Stiftung Kulturpflege und Denkmalschutz' (DPS) in Görlitz, funded by the Federal Government Commissioner for Culture and the Media (BKM), for funding the project. Further thanks to the glass conservators Sławomir Oleszczuk and Katarzyna Wójcik for their great cooperation and warm welcome in the glass restoration workshop in Wroclaw.

Furthermore, we want to thank Ruth Tenschert, John Hindmarch, Leander Pallas, Christoph Altmann and the Centre for Heritage Conservation Studies and Technologies (KDWT) for their support during the project. 


\section{References}

Akce, D., Remondino, F., Novák, D., Hanusch, T., Schrotter, G., Gruen, A., 2007. Performance Evaluation of a coded structured light system for cultural heritage applications. In: Proc. SPIE 6491, Videometrics IX, 64910V, pp. 1-12, http://doi.org/10.1117/12.705578.

Bellendorf, P., 2007. Metallene Grabplatten aus Franken und Thüringen aus dem 15. bis 18. Jahrhundert - eine interdisziplinäre Studie zum Denkmalbestand und seiner Gefährdung durch Umwelteinflüsse, Bamberg, Univ., Diss., pp. 122-123, https://nbn-resolving.org/urn:nbn:de:bvb:473opus-1368 (14. July 2019).

Brepohl, E., 2013. Theophilus Presbyter und das mittelalterliche Kunsthandwerk, Böhlau Verlag Cologne/ Weimar/ Vienna.

Chen, T., Lensch, H. P. A., Fuchs, C., Seidel, H.-P., 2007. Polarization and Phase-Shifting for 3D Scanning of Translucent Objects. In: Proceedings of IEEE Computer Society Conference on Computer Vision and Pattern Recognition (CVPR) Minneapolis, pp. 1-8.

Díaz-Marín, M. D. C., Aura Castro, E., Sánchez Belenguer, C., Vendrell Vidal, E., 2016. Cyclododecane as opacifier for digitalization of archaeological glass. In: Journal of Cultural Heritage. 17 pp. 131-140, https://doi.org/10.1016/j.culher.2015.06.003.

Drewello, R., Kleine, M., Bellendorf, P. 2010. Das mittelalterliche Mosesfenster in Straubing. In: Pilosi, L., Shepard, M. B., Strobl, S. (Eds.), The Art of Collaboration Stained-Glass Conservation in the Twentyfirst century, Harvey Miller Publishers, pp.183-192.

Drewello, R. Wetter, N., Rahrig, M., Bellendorf, P. 2010. 3D-Dokumentation mittelalterlicher Glasmalerei mit der Methode der 3D-Weißlicht-Streifenprojektion. In: Bornschein, F., Torge, M., Sabel, M., Feldmann, I., Kohl, A., Sterzing, N., Hahn, O., Drewello, R., Wetter, N., Rahrig, M., Bellendorf, P. (Eds.) Konservierung mittelalterlicher Glasmalerei im Kontext spezieller materieller und umweltbedingter Gegebenheiten. Dom zu Erfurt St. Marien, Domkapitel, pp. 142-154, https://doi.org/10.5165/hawk-hhg/epublication/43.

Drewello, R., Kleine, M., Bellendorf, P. 2016. Das Mosesfenster in St. Jakob in Straubing im Schnittpunkt von Wissenschaft, Restaurierung und topografischer Dokumentation. In: Corpus Vitrearum Deutschland / Germanisches Nationalmuseum (Eds.), Originale Kaltmalerei auf historischen Glasmalereien, arthistoricum.net, Heidelberg pp. 73-80, https://doi.org/10.11588/arthistoricum.383.545.

Eren, G., 2010. 3D scanning of transparent objects. Université de Bourgogne, 2010DIJOS029, tel00584061, https://tel.archives-ouvertes.fr/tel-00584061(14.July 2019). 
Floth, M., Breuer, M., 2011. Optische 3D-Messtechniken für die berührungslose, detaillierte Erfassung von Objektoberflächen in Archäologie und Denkmalpflege. In: Heine, K., Rheidt, K., Henze, F., Riedel, A. (Eds.) Von Handaufmass bis High Tech III, 3D in der historischen Bauforschung, Verlag Philipp von Zabern, Darmstadt/Mainz, pp. 8-13.

Gühring, J., 2002. 3D-Erfassung und Objektrekonstruktion mittels Streifenprojektion, In: Deutsche Geodätische Kommission (Eds.) Reihe C Heft Nr. 560.

Hullin, M.B., Fuchs, M., Ihrke, I., Seidel, H.P., Lensch, H.P.A. 2008. Fluorescent Immersion Range Scanning. In: ACM Transactions on Graphics 27, Issue 3, Article 87, https://doi.org/10.1145/1360612.1360686.

Ihrke, I., Kutulakos, K. N., Lensch, H. P. A., Magnor, M., Heidrich, W., 2010. Transparent and Specular Object Reconstruction. In: Computer Graphics forum, Vol. 29, 8, pp. 2400-2426, https://doi.org/10.1111/i.1467-8659.2010.01753.x.

Mériaudeau, F, Rantoson, R., Fofi, D., Stolz, C., 2012. Review and comparison of non-conventional imaging systems for three-dimensional digitization of transparent objects. In: J. Electron. Imag. 21 (2), 021105, pp. 1-6, https://doi.org/10.1117/1.JEl.21.2.021105.

Rahrig, M., Drewello, R., Lazzeri, A., 2018. Opto-Technical Monitoring - A Standardized Methodology to assess the Treatment of Historical Stone Surfaces. In: Int. Arch. Photogramm. Remote Sens. Spatial Inf. Sci., XLII-2, pp. 945-952, https://doi.org/10.5194/isprs-archives-XLII-2-945-2018.

Rantoson, R., Stolz, C., Fofi, D., Mériaudeau, F., 2010. Non Contact 3D Measurement Scheme for Transparent Objects Using UV Structured light. In: 20th International Conference on Pattern Recognition, Istanbul, IEEE, pp. 1646-1649, https://doi.org/10.1109/ICPR.2010.407.

Stylianidis, E., Remondino, F., (Eds.), 2016. 3D Recording, Documentation and Management of Cultural Heritage, Whittles Publishing, Dunbeath.

Salemi, G., Achilli, V., Boatto. G. 2008. 3D Virtual Modelling of a Gothic Stained-Glass Panel. Int. Arch. Photogramm. Remote Sens. Spatial Inf. Sci., Vol. XXXVII, Part B5, pp. 297-302.

Wedepohl, K. H., 2003. Glas in Antike und Mittelalter. Geschichte eines Werkstoffs, E. Schweizerbart'sche Verlagsbuchhandlung, Stuttgart.

Yeung, S.K., Wu, T.P., Tang, CH. K., Chan, T. F., Osher, S., 2011. Adequate reconstruction of transparent objects on a shoestring budget. CVPR 2011, Colorado Springs, CO, USA, IEEE, pp. 2513-2520. 


\section{Opto-Technical Monitoring - 3D-Techniken und multispektrale Bildgebung}

Wie in den vorangegangenen Kapiteln dargelegt, bietet die Verwendung einer einzelnen NDT bereits weitreichende Möglichkeiten für die Untersuchung und Dokumentation von Kulturerbe. Besonders die Erstellung von 3D-Vergleichen ist dabei ein ausgesprochen wertvolles Werkzeug für Ähnlichkeitsstudien und die Untersuchung von Veränderungen eines Objektes. Bei fortschreitenden Schadens- und Korrosionsprozessen handelt es sich jedoch um äußerst komplexe Mechanismen, die auf das Kulturerbe einwirken. Hier bedarf es häufig einer Kombination verschiedener Untersuchungsmethoden, um in der gemeinsamen Auswertung Rückschlüsse über die Intensität und die Ursache von Schadens- und Korrosionsprozessen zu ermitteln. Bislang ist hierzu häufig die Entnahme von Probenmaterial für Analysen im Labor oder andere objektschädigende Maßnahmen, wie etwa die Bohrwiderstandsmessung, notwendig. Der Einsatz dieser Methoden hat dabei freilich seine Berechtigung, da die Ergebnisse helfen können, das Voranschreiten der weiteren Schädigung zu stoppen. Häufig lassen sich über diese minimalinvasiven Eingriffe jedoch nur punktuelle Aussagen zum Zustand des Kulturerbes treffen, welche dann auf das große Ganze übernommen werden müssen. Untersuchungsmethoden, die eine flächendeckende Analyse der Veränderung von Kulturerbe erlauben, fehlten bislang.

Mit der Entwicklung des Opto-Technical Monitorings konnte dieses Desiderat aufgehoben werden. Hierzu wurden verschiedene NTDs auf der Basis von optischen Untersuchungsmethoden kombiniert. Zum Einsatz kam hochauflösendes 3D-Scanning mit einem SLS sowie die multispektrale Bildgebung der Wellenlängen im UV-, VIS- und IR-Spektrum. Die Korrelation wiederkehrender Messungen aus 3DVergleichen und Multispektralbildern erlaubt dabei, ein flächendeckendes Monitoring und eine tiefergehende Analyse der Veränderungen über das gesamte Untersuchungsareal einer Monitoringfläche. Auf diese Weise können witterungsbedingte Veränderungen von Oberflächen erfasst und charakterisiert werden.

Das Opto-Technical Monitoring wurde vom Verfasser im Rahmen des Forschungsprojektes NanoCathedral entwickelt, wo es zur Untersuchung der Einflüsse neu entwickelter Konsolidierungs- und Hydrophobierungsmittel auf historische Natursteinoberflächen genutzt wurde. Das Projekt wurde von der Europäischen Union im Forschungsrahmenprogramm ,Horizon 2020' als research and innovation action gefördert. Das Kooperationsprojekt mit 19 Partnern stand unter der Leitung von Prof. Dr. Andrea Lazzeri von der Universität Pisa. Die Universität Bamberg war als einer der Kooperationspartner unter anderem für das Monitoring zuständig. Die Koordination der Projektaufgaben für die Universität Bamberg oblag Prof. Dr. Rainer Drewello. 
Publikation 5: Opto-Technical Monitoring - A Standardized Methodology to Assess the Treatment of Historical Stone Surfaces (Rahrig/Drewello/Lazzeri 2018)

Der Artikel ist hier als Post-Print in einem angepassten Layout wiedergegeben. Für eine korrekte Zitierweise und Seitenzahlen bitte die Originalquelle verwenden:

Rahrig, M. / Drewello, R. / Lazzeri, A.: „Opto-Technical Monitoring - A standardized methodology to assess the treatment of historical stone surfaces." In: Int. Arch. Photogramm. Remote Sens. Spatial Inf. Sci., XLII-2, 2018, S. 945-952, Doi: https://doi.org/10.5194/isprs-archives-XLII-2-945-2018.

(peer reviewed Journal)

\section{Abstract:}

Monitoring is an essential requirement for the planning, assessment and evaluation of conservation measures. It should be based on a standardized and reproducible observation of the historical surface. For many areas and materials suitable methods for long-term monitoring already exist. But hardly any non-destructive testing methods have been used to test new materials for conservation of damaged stone surfaces. The Nano-Cathedral project, funded by the European Union's Horizon 2020 research and innovation program, is developing new materials and technologies for preserving damaged stone surfaces of built heritage. The prototypes developed are adjusted to the needs and problems of a total of six major cultural monuments in Europe. In addition to the testing of the materials under controlled laboratory conditions, the products have been applied to trial areas on the original stone surfaces. For a location-independent standardized assessment of surface changes of the entire trial areas a monitoring method based on opto-technical, non-contact and non-destructive testing methods has been developed. This method involves a three-dimensional measurement of the surface topography using Structured-Light-Scanning and the analysis of the surfaces in different light ranges using high resolution VIS photography, as well as UV-A-fluorescence photography and reflected near-field IR photography.

The paper will show the workflow of this methodology, including a detailed description of the equipment used data processing and the advantages for monitoring highly valuable stone surfaces. Alongside the theoretical discussion, the results of two measuring campaigns on trial areas of the Nano-Cathedral project will be shown.

\section{Introduction}

Monitoring is needed for the planning and assessment of a successful implementation of restoration measures. It has to be a standardized and reproducible observation, acquisition and controlling of processes or changes of historical objects. Depending on the object and the leading questions, there 
are a variety of different techniques and procedures used. These are, for example, combinations of visual anamnesis combined with technical and scientific examination methods (Nappi, Côte, 1997 and Van Balen, 1997).

Within the Nano-Cathedral project (www.nanocathedral.eu), funded by the European Union's Horizon 2020 research and innovation program, new materials and technologies for preserving damaged stone surfaces of built heritage were developed and tested on original stone surfaces of the Cathedral of Pisa (IT), the Cathedral of St. Peter and Mary in Cologne (DE), St. Stephen's Cathedral in Vienna (AT), Sint Baafs Cathedral of Ghent (BE), Santa Maria's Cathedral of Vitoria (ES) and the Oslo Opera House (NO). On average these trial areas were around $2 \mathrm{~m}^{2}$ in size. At present, location-independent assessment of preservation treatments still requires destructive methods such as drilling resistance measurement or the extraction of sample material for cross sections and scientific analysis (Auras, Meinhardt, Snethlage, 2010). As a result, only very small areas of the treated surfaces can be examined and so statements on the effects of the materials on larger areas are merely hypothetical. Therefore a suitable workflow using non-destructive testing methods (NDTs) to monitor the entire treated areas was developed.

\section{Functionality of the method}

Four opto-technical analytical methods regarded as NDTs were used for the monitoring. All technologies used result in images, and by using photogrammetry the different outputs are superimposed distortion-free and combined in a layer-based CAD-plan. In addition this methodology allows the overlaying of the different monitoring campaigns for a better visualization of changes.

The NDTs used are:

- 3D-Scanning: three-dimensional measurement of the surface topography

- VIS photography: high-resolution photography in the visible light spectrum

- UV-A-fluorescence photography: ultra violet fluorescence photography

- Reflected IR photography: reflected near-field infrared photography

\subsection{D-Scanning}

3D scanning is needed for the visualization of changes in the surface topography caused by continuous damage processes or a growth of the surface e.g. biogenic colonization or flaking and blistering. Furthermore the 3D measurement is used as the basis for rectifying the photographs of the other measurement techniques used. More precisely, Structured-Light-Scanning is used for the submillimetre-accurate, high-resolution documentation of the surface topography in 3D. Originally developed for quality control in manufacturing industry, this technology has been used in the field of heritage preservation and restoration for several years. The technique uses a projector which transmits 
a defined structured light pattern onto the surface of the object at different frequencies. With one or more cameras oriented at a defined angle to the projector, individual three-dimensional points on the surface are calculated using triangulation. The result is a single scan consisting of a point cloud, and by matching several individual scans, the complete object can be recorded. The individual scans are combined into an overall point cloud, which after further processing will result in a 3D surface model. Depending on the resolution of the digital image sensor and the camera lenses used, the resolution of the 3D measurement may vary within a range of approximately $1 \mathrm{~mm}$ to $15 \mu \mathrm{m}$. In order to ensure the desired resolution and accuracy of the measurement, it is necessary to calibrate the system before starting the measurement (Gühring, 2002, Akce, 2007, Vloth,Breuer, 2011).

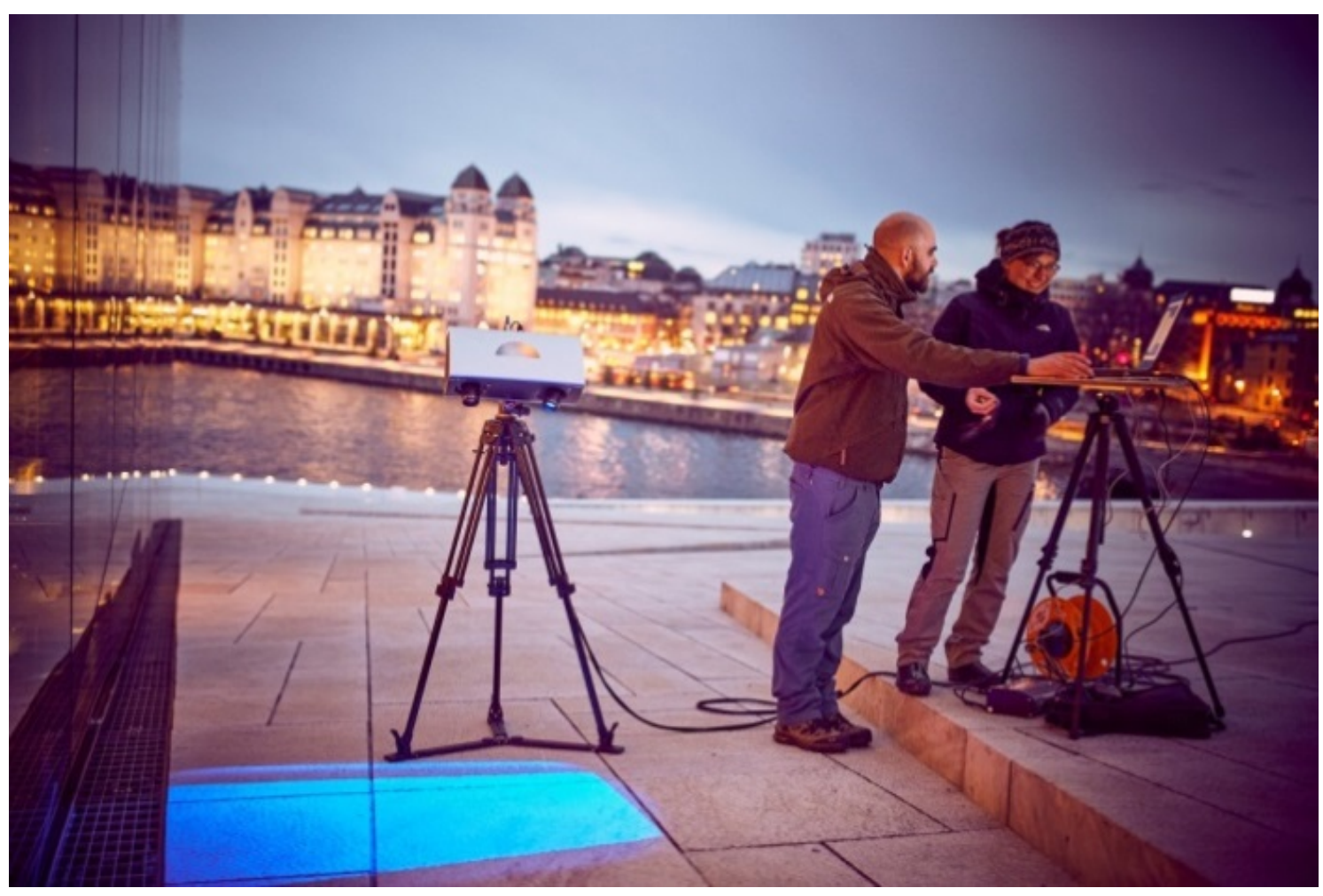

Figure 1. Capturing a trial area at the Oslo Opera House by using the Structured-Light-Scanner Comet L3D

For a three-dimensional measurement of the surfaces of trial areas in Nano-Cathedral a Comet L3D $5 \mathrm{M}$ from Zeiss Optotechnik was used (Figure 1). In this scanning system both the camera and the projector are fixed in the sensor head. By replacing the lenses, the measuring field of the scanner can be adapted to the required surface resolution. For capturing the trial areas in this project a measuring field with a resolution of $0.3 \mathrm{~mm}$ was used. In this case a single scan has a width of about $800 \mathrm{~mm}$. The system uses a blue LED as the light source, so it is able to capture reflective surfaces such as polished marble. The scanner can be operated on a simple photo tripod and a laptop for controlling. The system can easily be operated on tight scaffoldings. 
In general, the data was recorded during evening and nighttime to prevent over-irradiation of the structured-light pattern by sunlight. Approximately 10 to 15 individual scans were captured from different angles and positions in order to document the entire trial area. The individual scans were registered to each other as they were acquired.

After acquisition the scan data was processed further on high performance computers in the office. To reduce and compensate for possible errors due to the rough matching carried out on site, a so-called best-fit matching was carried out. Subsequently, the point cloud of the single scans was combined and processed in to a coherent surface model by triangulation. In the case of the Nano-Cathedral trial areas the surface models were created with a resolution of up to $0.3 \mathrm{~mm}$. All these steps are carried out in the scanner's own software, CometPLUS v.9.96.

The surface model was then imported to Geomagic Wrap 2017 to remove triangulation errors, i.e. intersections of triangles and spikes. Intentionally no holes were closed in the 3D model so that the data set consists only of measured data with no interpreted or reconstructed areas. Afterwards the surface model was exported as an STL-file and a distortion-free orthoimage was created by using Aspect3D v.16 software. This surface image shows the entire geometry of the trial area (Figure 2). This is used for observing the surface roughness, which is usually more difficult on textured stone surfaces. The generated view of the 3D model was imported to CAD software, providing the basis for rectification of the other images.

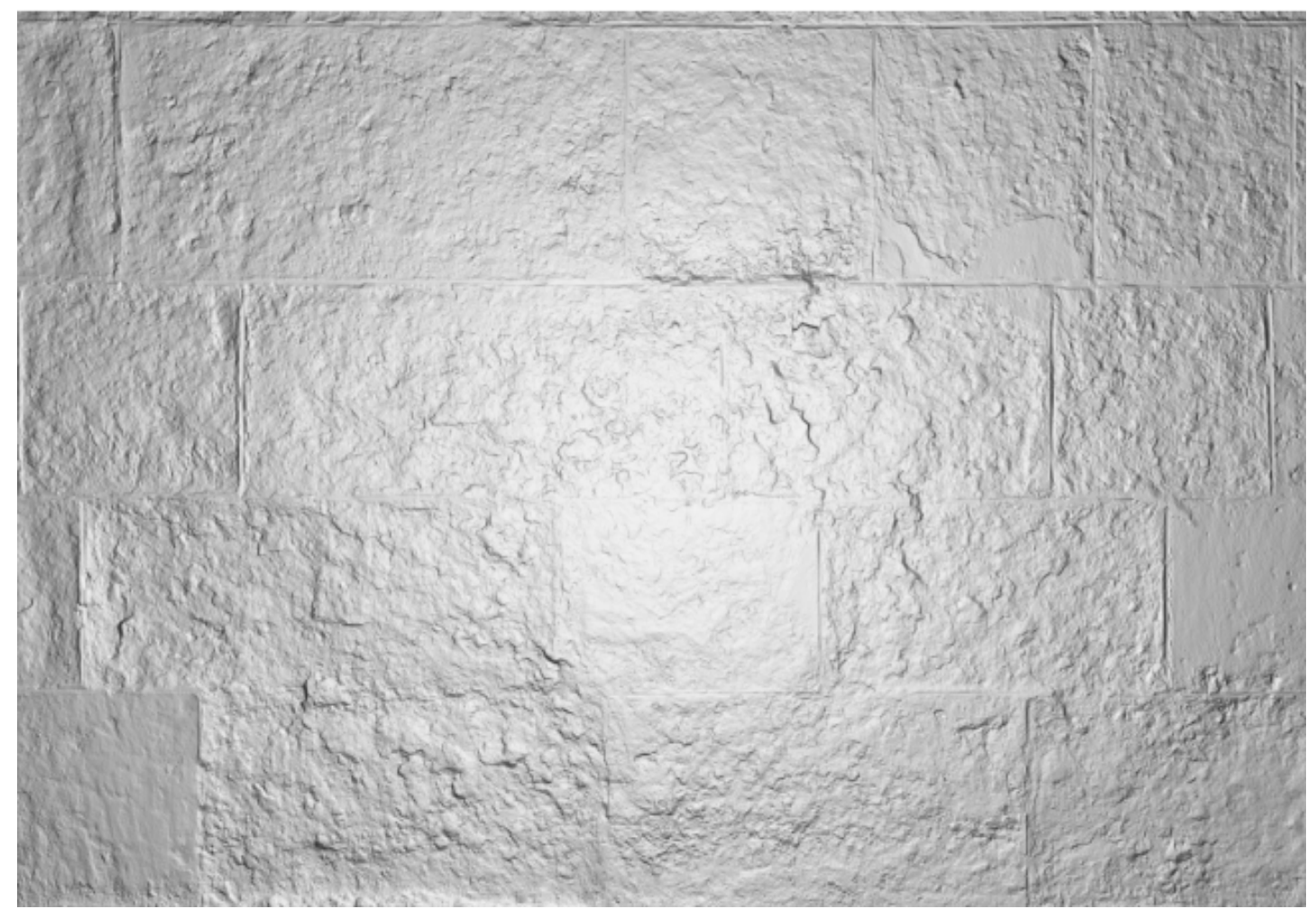

Figure 2. Orthoimage of the scan data of trial area 1 at Sint Baafs Cathedral in Ghent 
Furthermore the surface models are used for a mathematical 3D comparison. By using 3D inspection software, two data sets can be examined revealing differences in the surface topography. With this workflow, changes up to the $\mu \mathrm{m}$-range that have occurred between different monitoring campaigns can be recorded and visualized easily. In the case of Nano-Cathedral it was possible to capture the initial conditions of the trial areas in 2016 and again in 2017, after cleaning and treatment with newly developed consolidants and protectives.

The 2016 and 2017 data sets were imported into the software and aligned using best-fit matching. It should be noted that the matching was based on stable reference areas where no changes had occurred between the campaigns. In the case of trial area 1 at Sint Baafs Cathedral in Ghent (Figure 3), the matching was processed via the cement mortar joints between the stones. Subsequently, differences between the 3D models can be displayed in a color grid. The green parts show the areas where changes are less than the surface resolution and inside the tolerance $(+/-0.15 \mathrm{~mm})$. Yellow to red shows a growth of the surface in steps from $+0.15 \mathrm{~mm}$ up to $+15 \mathrm{~mm}$ and turquoise to dark blue show a loss of material in steps up to $-15 \mathrm{~mm}$. In this way sanding or spalling of the surface, as well as the growth of crusts and lifting of flakes can be measured and visualized in submillimeter accuracy. Processing the 3D comparison of the Nano-Cathedral trial areas was done by using InspectPRO v.5.22 software.

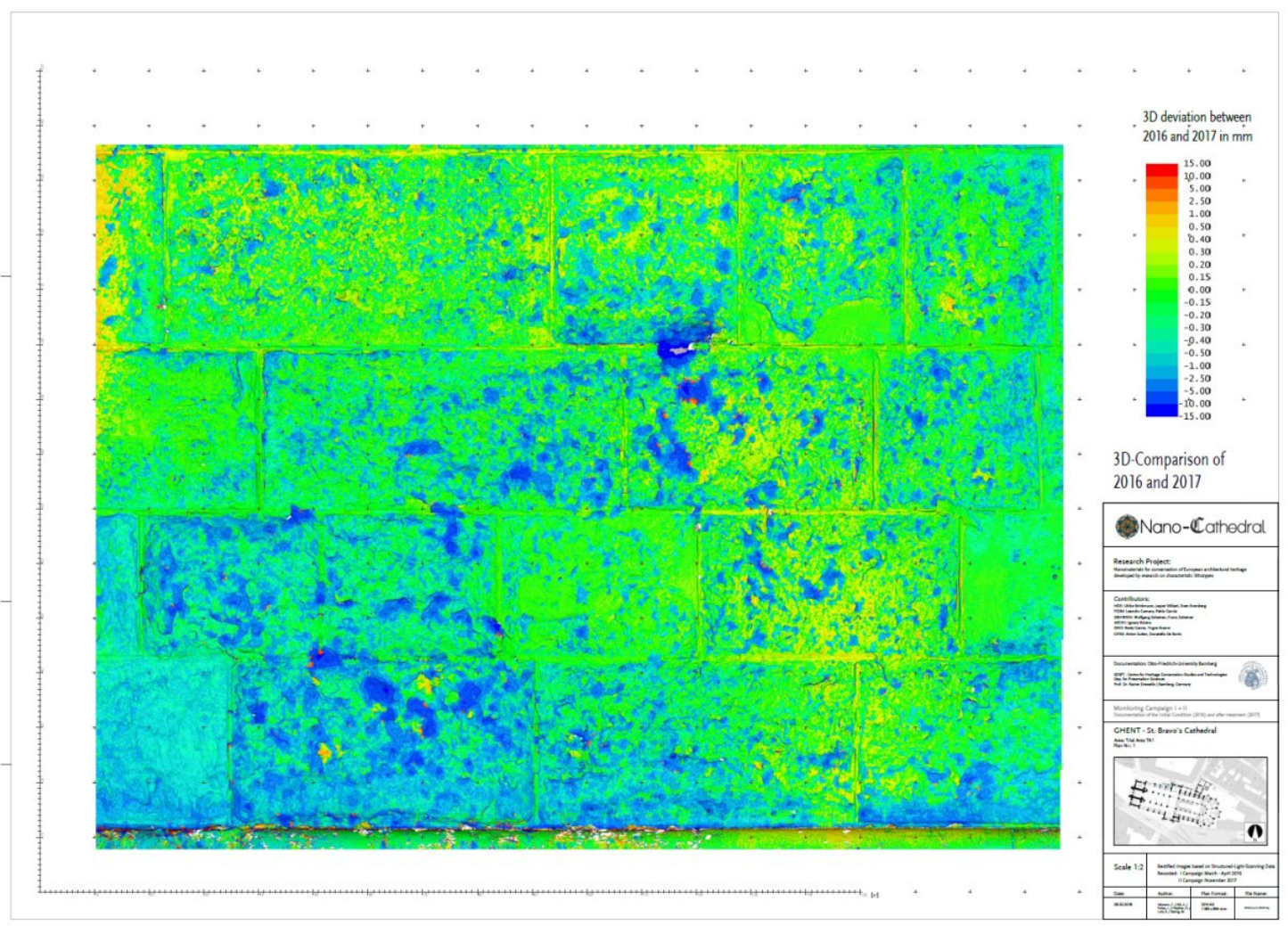

Figure 3. Trial area 1 at Sint Baafs Cathedral: 3D comparison of campaign 2016 and 2017. Stable areas are shown in green, red to yellow shows a growth and turquoise to blue a loss of the surface 


\subsection{VIS photography}

VIS photography is equivalent to well-known, classical color photography where only that part of the electromagnetic spectrum visible to the human eye is captured during image acquisition. The visible light spectrum includes electromagnetic waves in the range of about 400 to $700 \mathrm{~nm}$ (Figure 4). Shorter wavelengths in the ultraviolet and longer waves in the infrared are blocked using UV- and IR-filters, often preinstalled directly in the digital camera or its lenses (Verhoven, 2012, Verhoven, 2016).

\section{Electromagnetic spectrum}

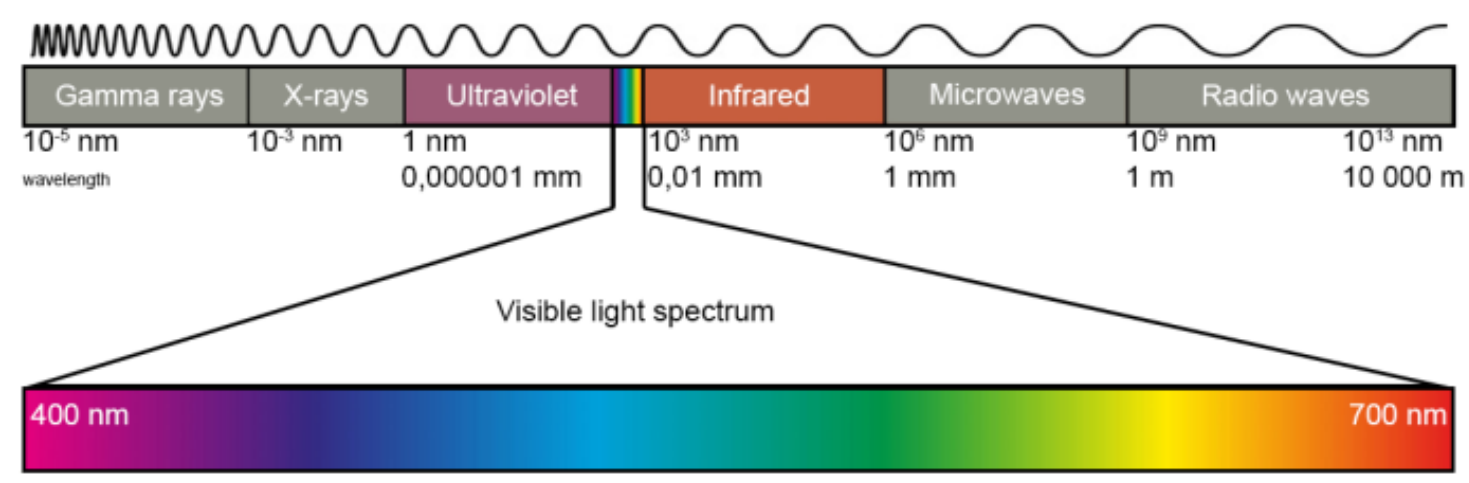

Figure 4. The electromagnetic spectrum

Many factors influence image acquisition, including exposure time, lens aperture, photosensitivity (ISO), white balance, color temperature, color management profiles (ICC, Adobe RGB) and external factors such as ambient light (daylight, cloudy or sun, artificial light, flash, etc.) (ibid.). For a standardized and repeatable VIS documentation of the monitoring areas, a complete documentation of these factors is essential. In addition the use of color management tools, such as "Kodak Color Control Patches" or the "X-Rite ColorChecker" with calibrated color patches and gray scales is necessary to ensure comparable color settings across all the surfaces. All images must be recorded in RAW format to avoid format-related, automated image processing (ibid. and Verhoven, 2010).

In the Nano-Cathedral project a Hasselblad H2 camera with a digital iXpress CFH back (39 megapixel image sensor) and an HC 3.5/50mm II lens was used for the VIS-photography of the trial areas. To ensure uniform lighting conditions and consistent color settings across the campaigns, the images were recorded at night. A BronColor Grafit A4 Power Pack with two Pulso G 3200J flashbulbs and softboxes was used as a light source (Figure 5). Camera and flashbulbs were mounted on tripods. To ensure color consistency as well as balance and exposure adjustment, all photos were recorded twice. In the first shot both the "Kodak Color Control Patch" and "QPcard 101 v3" were manually placed in the center of the image. The second shot used the same settings but without the control patches. Placing the patches in the image center ensures the most uniform illumination. If the corner or sides of the image area are used, external scattered light or possible color changes in the flashbulbs could negatively influence the color processing. 
Subsequent processing of the RAW images was carried out in Adobe Lightroom software using a calibrated and profiled monitor. During image processing, initial color adjustments were made based on the gray fields of the control patches. The use of two different patches in the same picture compensates potential errors. Afterwards the same settings were applied to the photo without patches to ensure color consistency. Finally the lens distortion was removed and the photos exported as high-resolution Tiffs using Adobe RGB color space.

The images for the second campaign were recorded using the same set up and settings to ensure color consistency. In some cases the trial areas of Nano-Cathedral were covered with dark crusts and therefore cleaned by micro abrasive blasting before treatment. In this case images of the second monitoring campaign might tend to be over-exposed compared to the first campaign. Because of this, stable reference areas of the stone surface where no cleaning and treatment had occurred were required. The color between campaigns was aligned using these areas and the color patches (Figure $6)$.

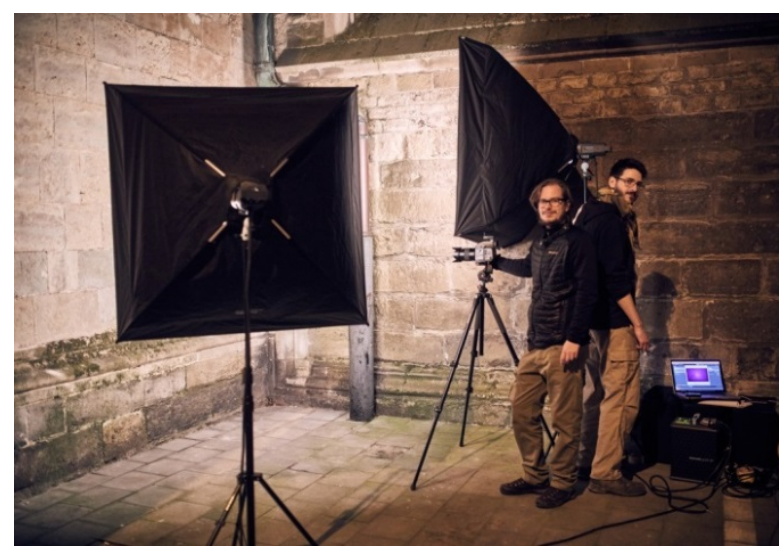

Figure 5. VIS-documentation of a trial area at Sint Baafs Cathedral in Ghent

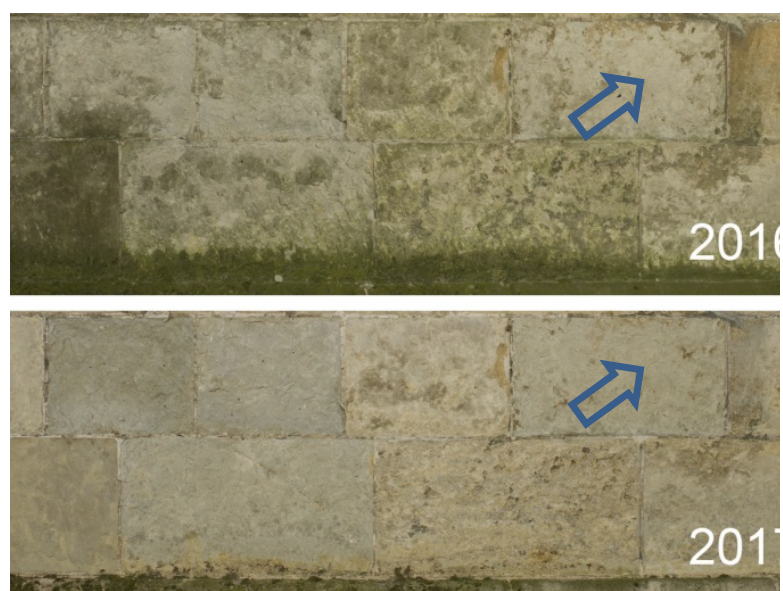

Figure 6. Trial area 1 at Sint Baafs Cathedral. Detail of VIS documentation 2016 and 2017. Blue arrow: reference area for color adjustment

\subsection{UV-A-fluorescence photography}

The electromagnetic wavelengths below $400 \mathrm{~nm}$ to about $1 \mathrm{~nm}$ include the ultraviolet (UV) spectrum (Figure 4). It is further divided into three to four categories but only two of them are relevant for photography. These are Near UV or UV-A with wavelengths between 320 and $400 \mathrm{~nm}$ and Middle UV or UV-B in the range of 280 to $320 \mathrm{~nm}$. Normal camera lenses start transmitting at around $320 \mathrm{~nm}$, conventional image sensors can acquire this wavelength too, so it is possible to record UV-A photographs without too much additional technical equipment. UV-A photography differs, however, from direct UV-A photography and UV-A-fluorescence photography (Dorell, 1994). 
For direct UV-A photography a UV-pass filter in front of the lens will restrict the transmitted light to the UV spectrum. The method is also called UV-reflectance-photography because only the UV radiation reflected by the object will be captured. Therefore, whilst the light source used must emit a huge amount of UV light, it can also emit additional wavelengths, since all other interfering wavelengths are blocked by the UV-pass filter. UV-reflectance-photography can be used for localization of organic material such as biological colonization, but until recently it has rarely been used in the field of heritage preservation.

With UV-fluorescence photography the fluorescent behavior of materials is used for image acquisition. During excitation with ultraviolet light, the object might reflect the energy as radiation in longer wavelengths in the visible light spectrum. This may result in distinct color differences which depend on the fluorescent behavior of different materials. For this method it is necessary that the light source emits only UV light and scattered light of other wavelengths has to be avoided. In addition a UV blocking filter is needed in front of the lens to capture only the UV fluorescence reflection in the visible spectrum. For heritage conservation UV-fluorescence photography is used to detect worn decorations, overwritten inscriptions on paper and certain pigments, as well as organic materials and the growth of gypsum crusts which is important for the observation of the stone surfaces in Nano-Cathedral (ibid. and Warda, 2011, Isacco, Darrah, 1993, Bravo Pereira, 2010).

Within the project, UV-A-fluorescence photography was carried out using the same equipment as the VIS photography. In addition, a UV-cut filter was placed in front of the camera lens. To generate pure UV light, the UV cut filters were removed from the Pulso G bulbs and replaced by Broncolor UV adapters.

UV-A-reflectance photography is only used when dealing with highly fluorescent materials, which would lead to overexposure in UV-A-fluorescence photography. For example, lime incrustations and calcium carbonate exhibit strong UV fluorescence resulting in a very bright and shiny white (Dorell, 1994). In this case additional UV-reflectance images may provide more detailed information in those previously overexposed areas. Until now UV-A-reflectance photography has not been needed in the project.

The UV images were recorded in RAW-format. To avoid contamination by scattered light and to guarantee reproducible conditions all images were taken during the nighttime. Based on the same color control patches and reference areas, color adjustment was carried out analogously to the VIS photography and according to the AIC specifications for UV photography (Warda, 2011). These patches might also fluoresce under UV energy but affordable color stable control patches are rare (Warda, 2011). The "Target UV and UV Gray Gard" (UV Innovations, 2018) might guarantee more accurate color 
adjustment. Nevertheless, getting comparable and reproducible image series using identical control patches between the campaigns is essential.

During image processing there is a difference between UV-A-fluorescence and the UV-A-reflectance photography which should be mentioned. Images from reflectance photography are artificially created to display the UV range normally invisible to the human eye. Therefore these images should be displayed in gray scale to avoid ambiguities. Fluorescence photography, however, shows reflection behaviors in the range of the visible light spectrum. Therefore these must be shown in color otherwise characteristic material differences will be lost (Figure 7; Warda, 2011, Isacco, Darrah, 1993, Bravo Pereira, 2010, Cosentino, 2014).
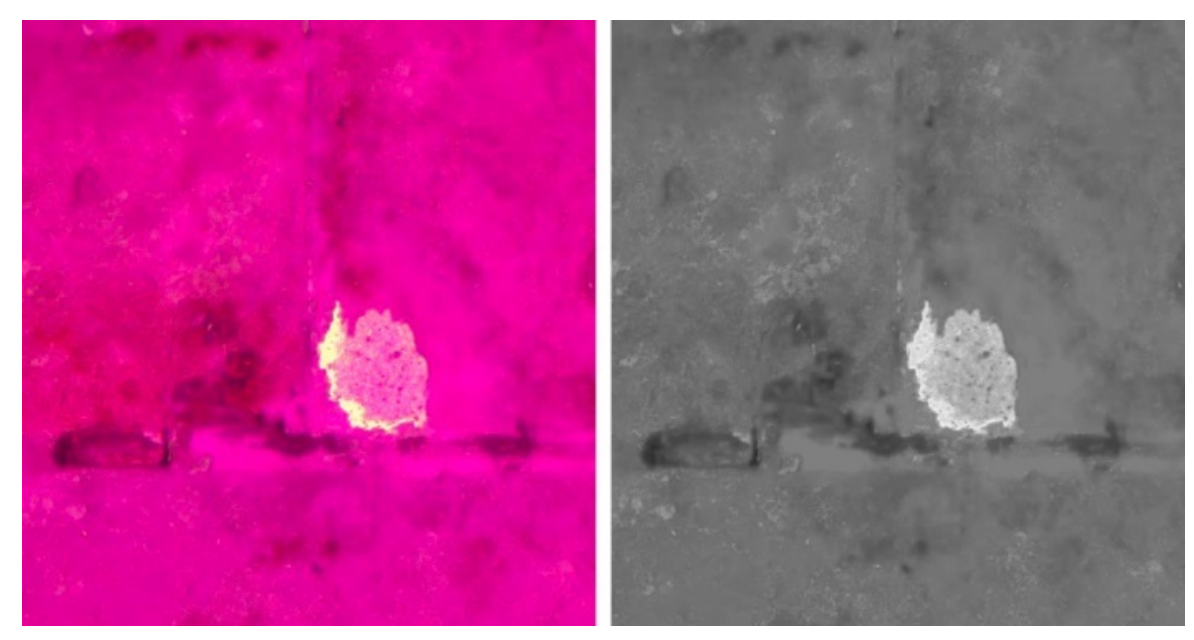

Figure 7. Ghent trial area 1, detail: Comparison of colored and gray scale UV-florescence image

\subsection{Reflected IR photography}

The infrared spectrum is located above the VIS up to a wavelength of about $1 \mathrm{~mm}$ (Figure 4). It is separated in to five parts, beginning with near infrared (NIR: 700-1000nm) via short-, mid- and longwavelength infrared (SWIR: 1.0-3.0 $\mathrm{m}$, MWIR: 3.0-5.0 $\mu \mathrm{m}$, LWIR: $5.0-14 \mu \mathrm{m}$ ) up to far infrared (FIR: $14 \mu \mathrm{m}-1 \mathrm{~mm})$. Photography of the different types of IR is used for thermography and in aerial photography to detect crops and soil marks or for differentiation of vegetation. Already in the NIR spectrum many materials and pigments have a different reflection behavior than in the VIS. Through this it is possible to distinguish between materials that look identical in visual light but differ in IR. With only a little effort it is possible to capture NIR using an ordinary digital camera. The camera has to be modified by removing the IR-cut filter in front of the image sensor, so that it is able to detect electromagnetic waves in a spectrum from around 320 up to $1100 \mathrm{~nm}$. For IR-reflectance photography the light source used has to provide IR radiation; though, sunlight, and also many conventional flash lamps, emits enough IR. IR-reflectance photography also requires an IR pass filter to ensure that only light in the IR wavelength range reaches the image sensor (Dorell, 1994, Cosentino, 2014, Sfarra, et al., 2015, Bloisi, et al., 2010, Falco, 2009). 


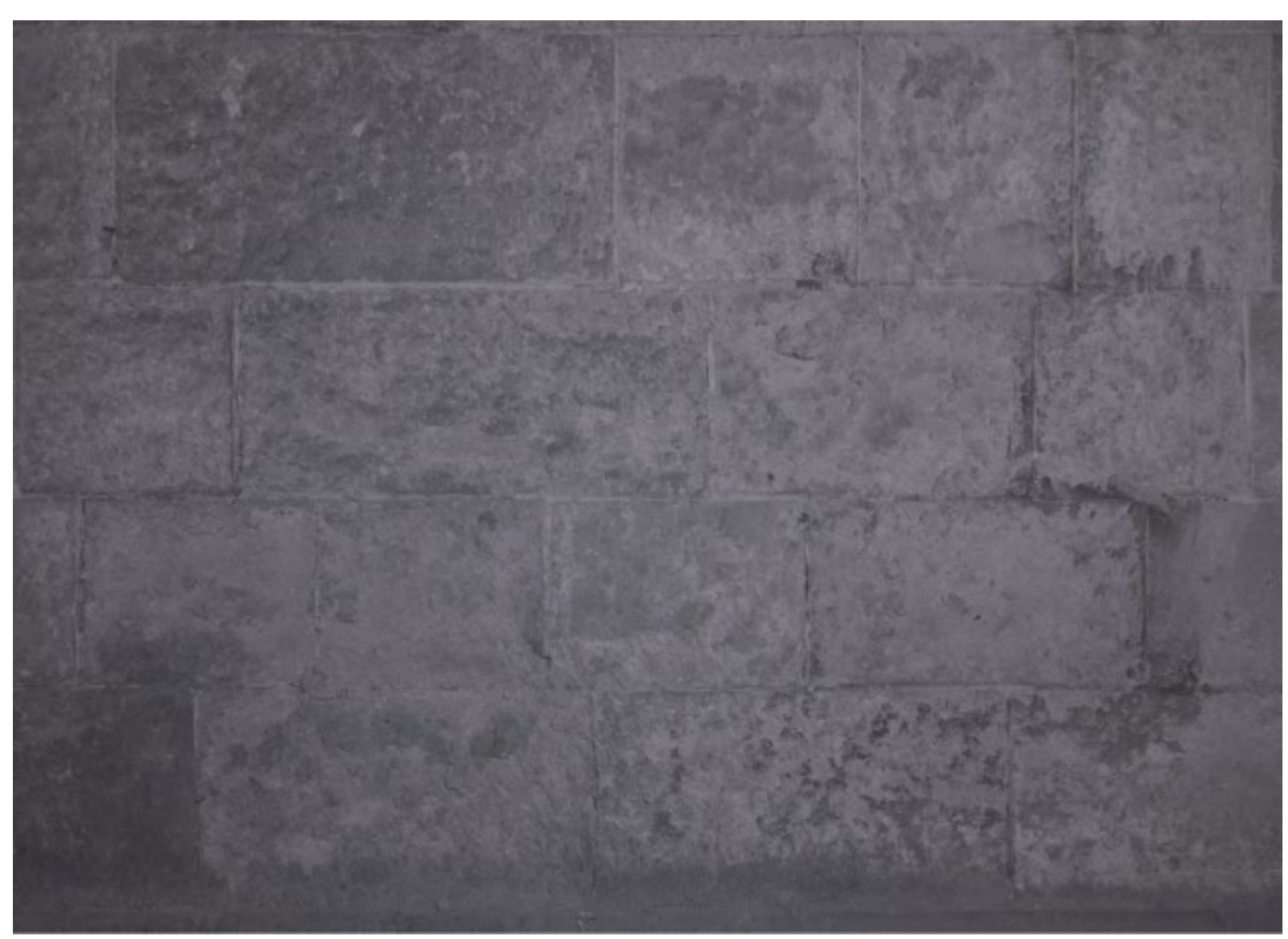

Figure 8. IR image of trial area 1 at Sint Baafs Cathedral in Ghent

For the reflected IR photography of the trial areas (Figure 8) a modified Canon EOS 5d Mark II with 21 megapixels and a Sigma Art 35 mm f1.4 DG lens in combination with the Broncolor flash system was used. To ensure that only electromagnetic radiation in the IR spectrum reaches the image sensor, a B + W 092 IR pass filter was used in front of the lens. This filter is similar to the often recommended Kodak Wratten 89B (Warda, 2011).

Image processing was done analogously to VIS and UV photography. Color adjustment via the gray patch on the control patches worked well and delivered stable results across the campaigns. IR images will not contain any surface information within the visible light spectrum. To avoid color ambiguity, the image has to be transferred in to gray scale.

\subsection{CAD plans}

After capturing and processing the images, stable, comparable and reproducible color conditions are available. But depending on the variety of cameras and lenses used for the different types of documentation, the single shots will not show exactly the same image section and depending on the camera angle and lens distortion the images are not right in scale. To guarantee an accurate, comparable analysis of the surfaces cross-technology and cross-campaign the images need to be superimposed distortion-free on each other. Therefore the images are further processed in CAD plans using photogrammetry. 
Usually this method needs targets or control points fixed to the surface in the images and which have been measured by total station for scaling (Wiedemann, 2004). However, scan data make these targets unnecessary. As described above, the scans are true in scale and it is possible to easily render orthoimages from them. These images were imported to AutoCAD 2016 and used as reference. In the next step a UV, VIS or IR image will be imported via the add-on Faro PhoToPlan 2017. By using natural control points such as edges, cracks or holes which are visible on the surface in both, the scan and the image, the images can be rectified. The individual image rectification was carried out with approximately 10 to 15 natural control points per photo, so a submillimeter-accurate rectification and localization of the surfaces was possible.

During the rectification process PhoToPlan creates a new image file in Tiff or Jpeg format. Unfortunately an automatic color manipulation was observed when the image was resampled. This color falsification needs to be compensated for. All images are linked as external references to AutoCAD, so it is possible to adjust the color of the rectified image to the correct values using Photoshop. During this color adjustment, the geometry and number of pixels of the image must not be changed otherwise the orientation and scaling in AutoCAD will be lost.

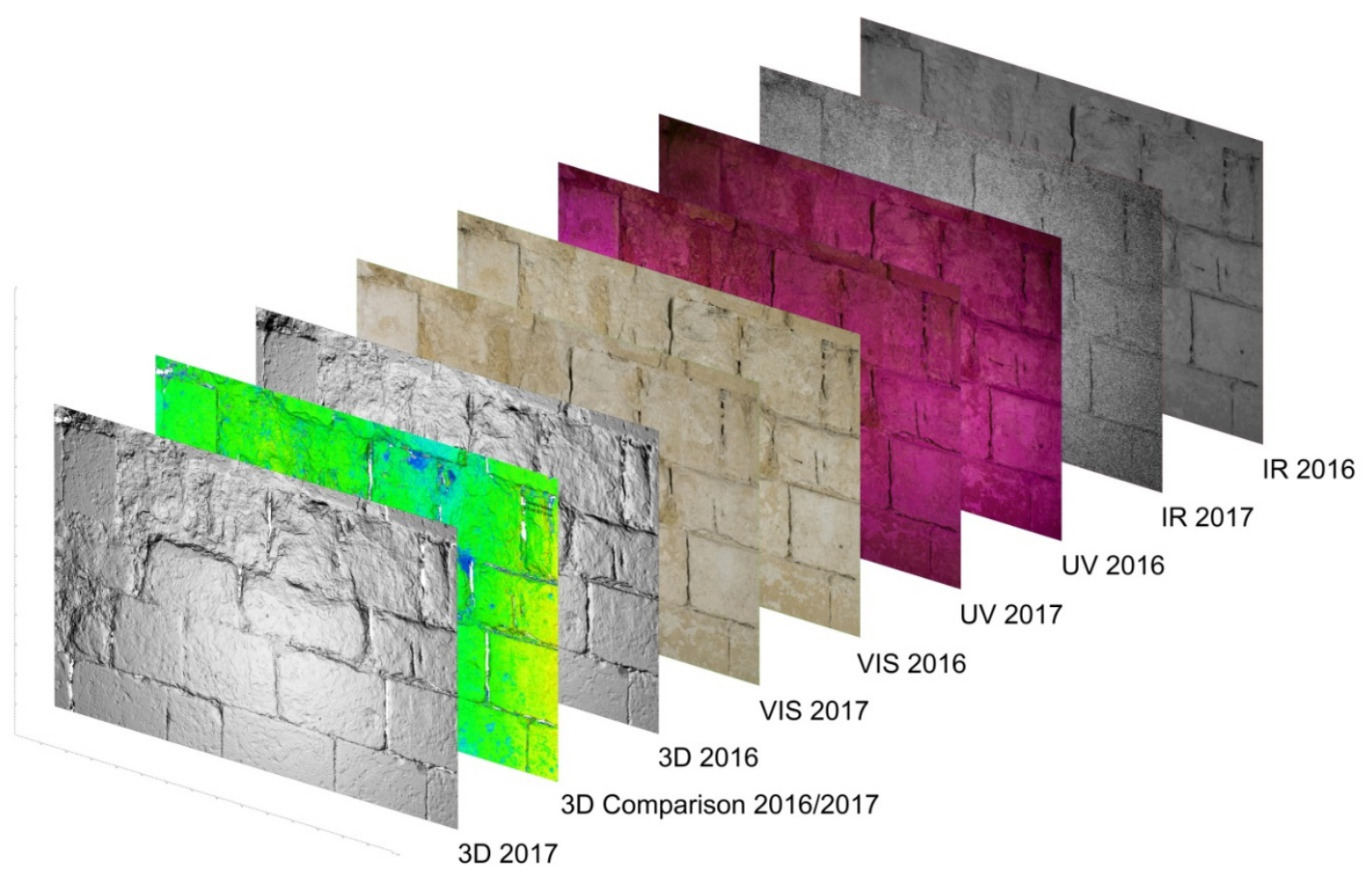

Figure 9. Trial area 3 at the Cathedral of Santa Maria de Vitoria; schematic representation of the superimposed images 
After all of the images had been rectified, readjusted and superimposed in CAD, they were uniformly cropped to show exactly the same area (Figure 9). Per campaign, each technology used is arranged on a separate layer. For easier analysis a $10 \mathrm{~cm}$ cross grid and a scale bar are included in the plan layout. This simplifies analysis, measurements and mapping of findings in the plan. The results are available as an AutoCAD DWG-file and layer based PDF.

\subsection{Report}

To guarantee cross-campaign comparable results, an accurate documentation is essential. Therefore the report must contain all information regarding the devices and settings used for each of the different techniques. For 3D-scanning it must include model designation, lenses, resolution and calibration procedures as well as the processing steps and settings. For all methods of photography and for each image the color control patches, camera model and lenses used including all settings i.e. exposure time, aperture, ISO, white balance, color temperature, camera profile (color values) as well as the flash system with its settings, lamps and size of soft boxes need to be noted. As well as the technological components, the surrounding conditions must be documented in the report too. This includes date and time of documentation, weather conditions and temperature as well as the surface conditions. These involve the actual conditions (dry or wet surface) and information about possible conservation measures carried out between the monitoring campaigns.

\section{Results}

Two opto-technical monitoring campaigns have been carried out for the Nano-Cathedral project. Their aim was to capture as much information as possible regarding the surface of the trial areas. The first campaign in April/May 2016 was used for documenting the initial condition of the trial areas. By comparing the images from the various technologies used, restorers of the cathedral workshops have carried out a preliminary investigation on site. Surface damage phenomena as well as surface details like paint residues were easily differentiated, characterized and mapped on the plan set. Using this information, the restorers could determine preparatory measures needed before treatment with new products. In some cases the surfaces needed just a pretreatment with biocides and were cleaned with distilled water. Other trial areas were covered by black crusts and a mechanical cleaning by micro abrasive blasting was required.

After completion of the preparatory measures, the testing fields for the application of the newly developed consolidants and protectives were defined and the treatment carried out in summer 2017. The exact location of the treatments was again documented in the CAD plans. In the case of trial area 3 at Vitoria, four different consolidants or combinations of consolidants and one protective were applied. Some of the new products take up to six weeks to bind and harden. Afterwards, the second monitoring campaign was carried out in October/November 2017. 
Now by comparing the two campaigns (Figure 9) surface changes caused by one year of weathering, as well as cleaning measures and the treatment with new materials can be detected and visualized. The 3D-Comparison (Figure 11) shows a fairly stable surface. The biggest material loss of up to $25 \mathrm{~mm}$ is located at the corners of the stone blocks and along the joints. Growth of the surface is only occasionally noticeable, but the thin application of the new conservation products is not visible. In the VIS image, on the other hand, it is difficult to detect the surface loss, but color changes due to the treatment can easily be detected. In some areas a yellowing of the mortar and stone block is recorded (Figure 12). However, the difference between the applied agents is not apparent for all the products. These can be visualized for instance in the UV fluorescence image (Figure 13). UV-fluorescence photography may be a proper method for documenting the weathering of UV-active treatments, whereas growth of biological colonization and crusts may be visualized using IR too.

Table 10 shows the advantages and disadvantages of each technique used. It can be stated that a comprehensive analysis of the changes is successful using a combination of the individual techniques.

\begin{tabular}{|c|c|c|c|c|}
\cline { 2 - 5 } \multicolumn{1}{c|}{} & $\begin{array}{c}\text { 3D } \\
\text { Model }\end{array}$ & $\begin{array}{c}\text { VIS } \\
\text { image }\end{array}$ & $\begin{array}{c}\text { UV-A- } \\
\text { fluores. } \\
\text { Image }\end{array}$ & $\begin{array}{c}\text { Refl. IR } \\
\text { image }\end{array}$ \\
\hline $\begin{array}{c}\text { Growth of the } \\
\text { surface }\end{array}$ & + & $/$ & $/$ & $/$ \\
\hline $\begin{array}{c}\text { Loss of the } \\
\text { surface }\end{array}$ & + & $/$ & $/$ & $/$ \\
\hline $\begin{array}{c}\text { Color changes } \\
\text { Treatment by } \\
\text { cons. products }\end{array}$ & - & + & $/$ & - \\
\hline $\begin{array}{c}\text { Weathering of } \\
\text { the surfactants }\end{array}$ & $/$ & + & + & - \\
\hline $\begin{array}{c}\text { Growth of crusts } \\
\text { Brological } \\
\text { colonization }\end{array}$ & $/$ & $/$ & + & + \\
\hline
\end{tabular}

Table 10. Suitability (+), limitations (/) and disadvantages (-) of the single NDTs in an optotechnical monitoring 


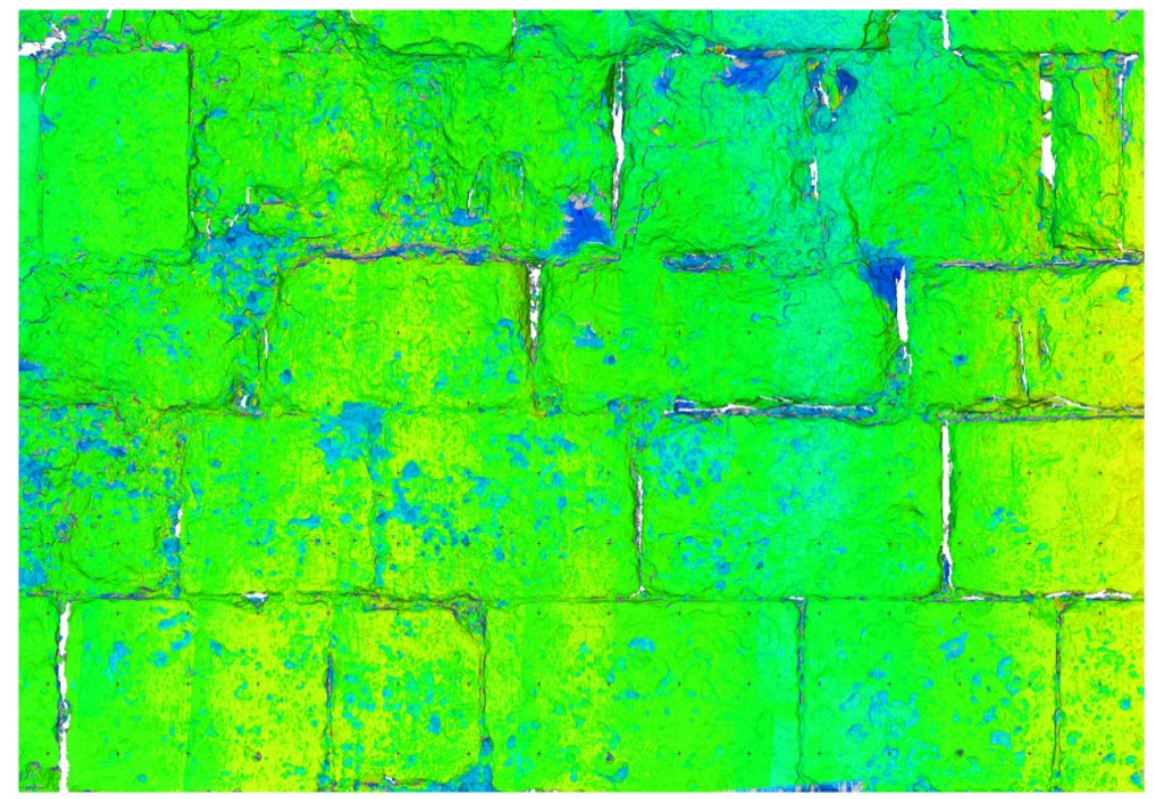

Figure 11. Trial area 3 at Santa Maria de Vitoria. 3D-Comparison of 2016 and 2017. Green: stable surface $+/-0.15 \mathrm{~mm}$; yellow to red: growth up to $+1 \mathrm{~mm}$; turquoise to blue: loss up to $-25 \mathrm{~mm}$
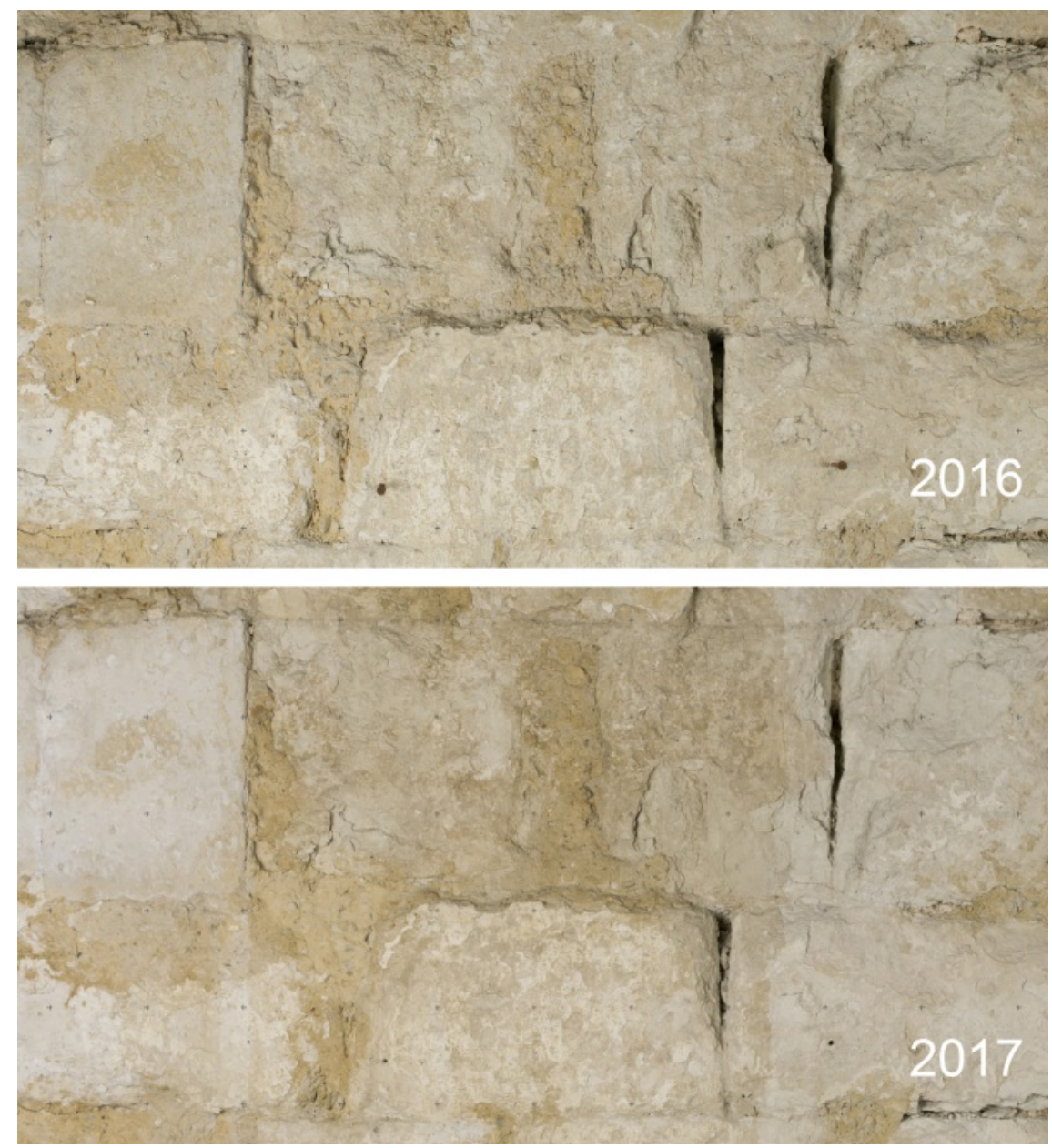

Figure 12. Trial area 3 at Santa Maria de Vitoria. Detail of the VIS photography. Comparison of 2016 (top) and 2017 (bottom) 


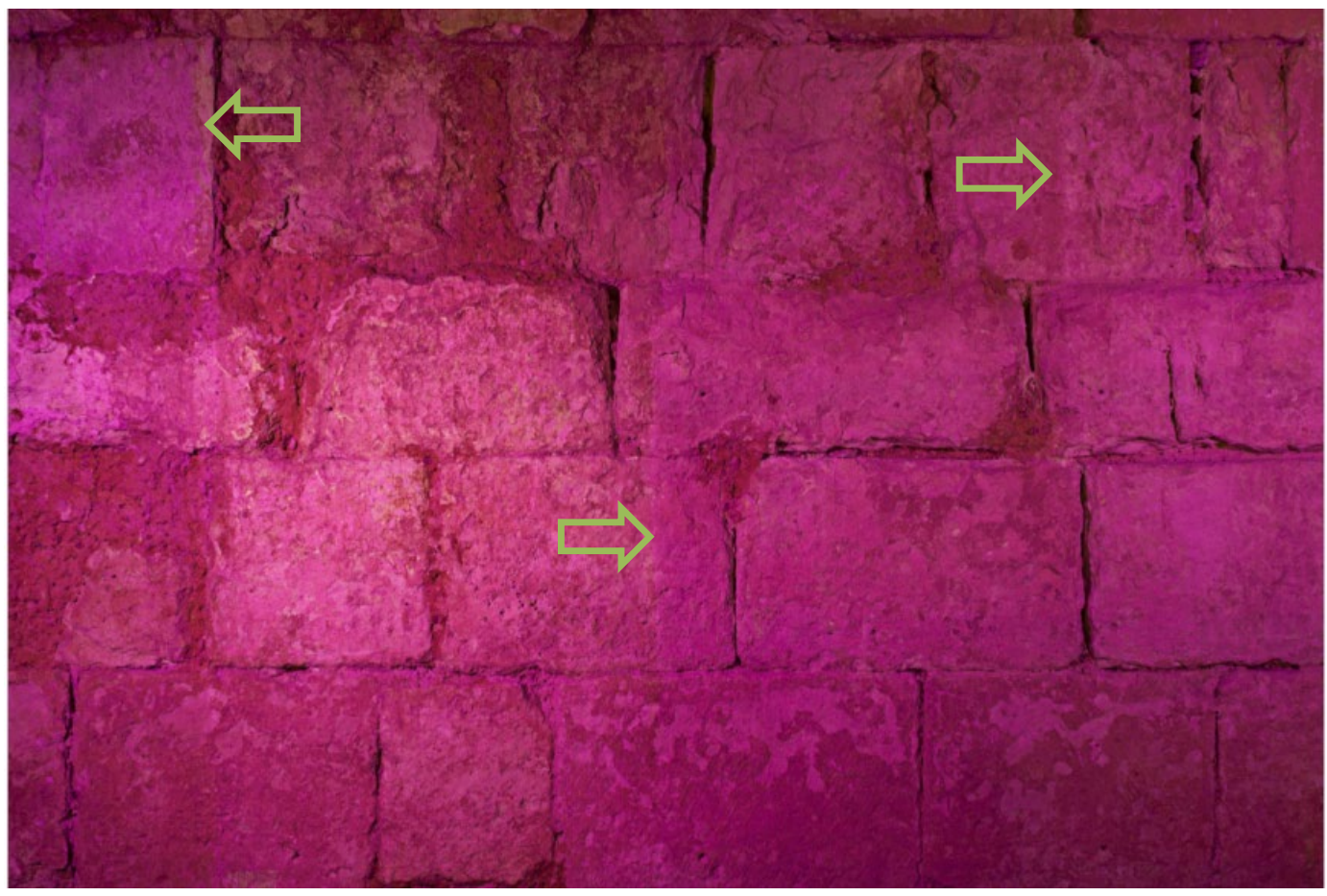

Figure 13. Trial area 3 at Santa Maria de Vitoria. UV-A-fluo-rescence image 2017. Arrow: application border

\section{Conclusion}

By combining several non-contact and non-destructive documentation methods a suitable workflow for an opto-technical monitoring of stone surfaces has been tested and described. It uses UV photography, high-resolution VIS photography, reflected IR photography, 3D scanning and 3D surface comparisons. The aim is to gain as much information as possible on the change in surfaces. The overlaying of the different techniques can increase the value of the observation and analysis of the surfaces significantly and changes between several monitoring campaigns can be compared directly.

The use of this method can help in the studies of new preservation materials and their weather ability. With comparatively little effort, the entire trial area can be examined. Combined with the analysis of sample material in the laboratory, this methodology will provide helpful information on the consistency and effectiveness of the applied materials.

The devices and software described are examples of suitable monitoring equipment. The decisive factor for monitoring procedures is the precise documentation of the individual steps taken and the devices used. At least, a uniform recording and processing workflow has to be ensured for the different monitoring campaigns. Then monitoring will be an essential tool to control and evaluate the application of newly developed products for stone surfaces. 


\section{Acknowledgements}

Nano-Cathedral project has received funding from the European Union's Horizon 2020 research and innovation programme under grant agreement No 646178.

We have to thank all partners for the fruitful cooperation within the project. Special thanks to the colleagues of Fundación Catedarl Santa María in Vitoria, Sint Baafs Cathedral and Bressers Architects in Ghent, the Oslo Opera House and STATSBYGG in Oslo for the kind permission to use images of their sites in this paper. Last but not least, sincere thanks to the photographer David Höpfner and Anna Luib, Christoph Altmann, Katrin Vill and Leander Pallas for their grateful support during documentation and processing of the monitoring areas.

\section{References}

Akce, D., et al, 2007. Performance Evaluation of a coded structured light system for cultural heritage applications, Proc. SPIE 6491, Videometrics IX, 64910V. http://doi.org/10.1117/12.705578

Auras, M., Meinhardt, j., Snethlage, R. (Eds.) 2010. Leitfaden Naturstein-Monitoring, Nachkontrolle und Wartung als zukunftsweisende Erhaltungsstrategie. Fraunhofer IRB Verlag, Stuttgart.

Bloisi, F., et al. 2010. Infrared image analysis and elaboration for archaeology: The case study of a medieval "capsella" from Cimitile, Italy. Appl. Phys. B, 101, 2010, pp. 471-479. https://doi.org/10.1007/s00340-010-4049-z

Bravo Pereira, L., 2010. UV Fluorescence Photography of Works of Art: Replacing the Traditional UC Cut Filters with Interference Filters. INT J CONSERV SCI 1 (3), 2010, pp 161-166.

Cosentino, A., 2014. Identification of pigments by multispectral imaging; a flowchart method. Heritage Science 2014 2:8. https://doi.org/10.1186/2050-7445-2-8

Dorell, P., 1994. Photography in Archaeology and Conservation, Second Edition, Chapter 11: UltraViolet and Infra-Red Photography, Cambridge University Press, pp. 198-207. https://doi.org/10.1017/CBO9780511621932.013

Falco, C., 2009. Invited Article: High resolution digital camera for infrared reflectography. Review of Scientific Instruments 80. https://doi.org/10.1063/1.3174431

Floth, M., Breuer, M., 2011. Optische 3D-Messtechniken für die berührungslose, detaillierte Erfassung von Objektoberflächen in Archäologie und Denkmalpflege. Heine, K., Rheidt, K., Henze, F., Riedel, A. (Eds.) Von Handaufmass bis High Tech III, 3D in der historischen Bauforschung, Verlag Philipp von Zabern, Darmstadt/Mainz, pp. 8-13. 
Gühring, J., 2002. 3D-Erfassung und Objektrekonstruktion mittels Streifenprojektion, Deutsche Geodätische Kommission (Eds.) Reihe C Heft Nr. 560.

Isacco, E., Darrah, J., 1993. The Ultraviolet-Infrared Method of Analysis a Scientific Approach to the Study of Indian Miniatures, in: Artibus Asiae, Vol 53, No. 3/4, pp. 470-491. http://doi.org/10.2307/3250528

Nappi, A., Côte, P., 1997. Nondestructive Test Methods Applicable to Historic Stone Structures. Baer, N.S., Snethlage, R., (Eds.) Saving our Architectural Heritage: The Conservation of Historic Stone Structures, John Wiley \& Sons Ltd, Chichester, pp. 151-166.

Sfarra, S., et al. 2015. Subsurface imaging for panel paintings inspection: A comparative study of the ultraviolet, the visible, the infrared and the terahertz spectra. Opto-Electronics Review, 23, 1, pp. 8899. https://doi.org/10.1515/oere-2015-0013

UV Innovations 2018. Target-UV \& UV-Gray card for color control under UV. http://www.uvinnovations.com/target-uv (last access 2018-03-20).

Van Balen, K., 1997. Monitoring of Degradation: Selection of Treatment Strategies. Baer, N.S., Snethlage, R., (Eds.) Saving our Architectural Heritage: The Conservation of Historic Stone Structures, John Wiley \& Sons Ltd, Chichester, pp. 167-180.

Verhoeven, G., 2010. It's all about the format: unleashing the power of RAW aerial photography. International Journal of Remote Sensing, 31, 8, pp. 2009-2042. https://doi.org/10.1080/01431160902929271

Verhoeven, G., 2012. Methodes of Visualisation. Edwards, H.G.M., Vandenabeele, P., (Eds.) Analytical Archeometry, selected Topics, pp. 3-48. http://dx.doi.org/10.1039/9781849732741

Verhoeven, G., 2016. Basics of Photography for Cultural Heritage Imaging. Stylianidis, E., Remondino, F. 3D Recording, Documentation and Management of Cultural Heritage, Whittles Publishing, Dunbeath, pp. 127-251.

Warda, J., 2011. The AIC Guido to Digital Photography and Conservation Documentation, second edition, American Institute for Conservation, Washington.

Wiedemann, A., 2004. Handbuch der Bauwerksvermessung. Geodäsie - Photogrammmetrie Laserscanning. Springer Basel AG, Basel, pp.206-224. 


\section{Dokumentation und Archivierung}

Neben der Durchführung von Projekten und der Auswertung der Daten für die jeweilige Fragestellung stellen die Dokumentation der durchgeführten Maßnahmen und die Archivierung der Informationen weitere wichtige Punkte im respektvollen Umgang mit Kulturerbe dar. ${ }^{254}$ Besonders die Langzeitarchivierung elektronischer Daten ist dabei immer noch ein nicht vollständig gelöstes Problem der Archive von Museen und Landesämtern. Für Text- und Bilddateien wurden in den vergangenen Jahren verschiedene Lösungen entwickelt. Im Umgang mit 3D-Daten fehlte jedoch bislang eine adäquate Lösung. Vom Verfasser wurden 2016/2017 standardisierte Dateiformate und eine Struktur für die Ablage und Archivierung der Datensätze entwickelt, welche in Zusammenarbeit mit der 3DArbeitsgruppe des Bayerischen Landesamts für Denkmalpflege (BLfD) präzisiert wurden. Künftig kann dies eine Verwaltung der Daten ermöglichen, die den Anforderungen der Dokumentation und Archivierung von Maßnahmen an Objekten des Kulturerbes gerecht wird. Darüber hinaus soll mit der zentralen Archivierung der Roh- und Ergebnisdaten am BLfD eine ressourcensparende Grundlage für künftige Maßnahmen an den jeweiligen Objekten geschaffen werden.

\footnotetext{
${ }^{254}$ Vgl. Kapitel 2.4.;ethischer Grundsatz Nr. 7. Alle Maßnahmen an einem Kulturerbe sollen ausführlich dokumentiert und angemessen veröffentlicht werden und Grundsatz Nr. 8. Die Dokumentationen und alle maßnahmenrelevanten Informationen sind als Zeitdokument zu archivieren, S. 19.
} 
Publikation 6: Wohin mit all den Scans? Über die dauerhafte Archivierung von 3D-Daten bedeutender Kulturgüter am Beispiel des Bamberger Kaisergrabs (Rahrig 2017)

Der Artikel ist hier als Post-Print in einem angepassten Layout wiedergegeben. Für eine korrekte Zitierweise und Seitenzahlen bitte die originalquelle verwenden:

Rahrig, M.: „Wohin mit all den Scans? - Über die dauerhafte Archivierung von 3D-Daten bedeutender Kulturgüter am Beispiel des Bamberger Kaisergrabs. “In: Franz, B. / Vinken, G. (Hrsg.): Das Digitale und die Denkmalpflege: Bestandserfassung - Denkmalvermittlung - Datenarchivierung - Rekonstruktion verlorener Objekte, Veröffentlichungen des Arbeitskreises Theorie und Lehre der Denkmalpflege e.V., Band 26, Heidelberg, 2017, S. 130 - 139, Doi: http://dx.doi.org/10.11588/arthistoricum.263.348.

\section{Zusammenfassung}

Die 3D-Dokumentation von Kulturgütern hat sich in den letzten Jahren zu einer gängigen Methode entwickelt. Messgenauigkeit, Qualität und Güte der Datensätze wachsen dabei stetig, so dass diese 3D-Modelle inzwischen als eigenständiges und schützenswertes digitales Kulturerbe eingestuft werden müssen. Doch was genau passiert mit den Daten nach ihrer Anfertigung und Auswertung? Wie genau erfolgt die Bewahrung der 3D-Daten bedeutender Kulturgüter für kommende Generationen? Nationale und internationale Kulturportale haben sich diesem Problem angenommen und stellen ihre Daten online einer breiten Öffentlichkeit zur Verfügung. Doch es stehen auch Museen, Sammlungen und Landesämter in der Pflicht das digitale Kulturerbe langfristig zu schützen und zu erhalten. Daher müssen Kopien der Datensätze in den Archiven der Einrichtungen dauerhaft aufbewahrt werden. Im Zuge der hochauflösenden, dreidimensionalen Dokumentation des Bamberger Kaisergrabs, einem herausragenden Meisterwerk mittelalterlicher Bildhauerkunst von Tilman Riemenschneider, wurden innerhalb der 3D-Arbeitsgruppe des Bayerischen Landesamts für Denkmalpflege (BLfD) einheitliche Datenformate und eine standardisierte Ablagestruktur definiert, mit deren Hilfe 3D-Daten auf langlebigen, gläsernen DVDs archiviert werden sollen. Auf diese Weise sollen künftig 3D-Daten bedeutender Kulturgüter, wie beispielsweise die bereits bestehenden Datensätze des Bamberger Reiters, des Grabmals Papst Clemens II. aber auch neu erfasste Daten am BLfD archiviert werden. Eine kosten- und arbeitsintensive Datenpflege, wie sie gängige Speichermedien aufgrund ihrer stark limitierten Lebensdauer erfordern, soll so künftig deutlich reduziert werden. 


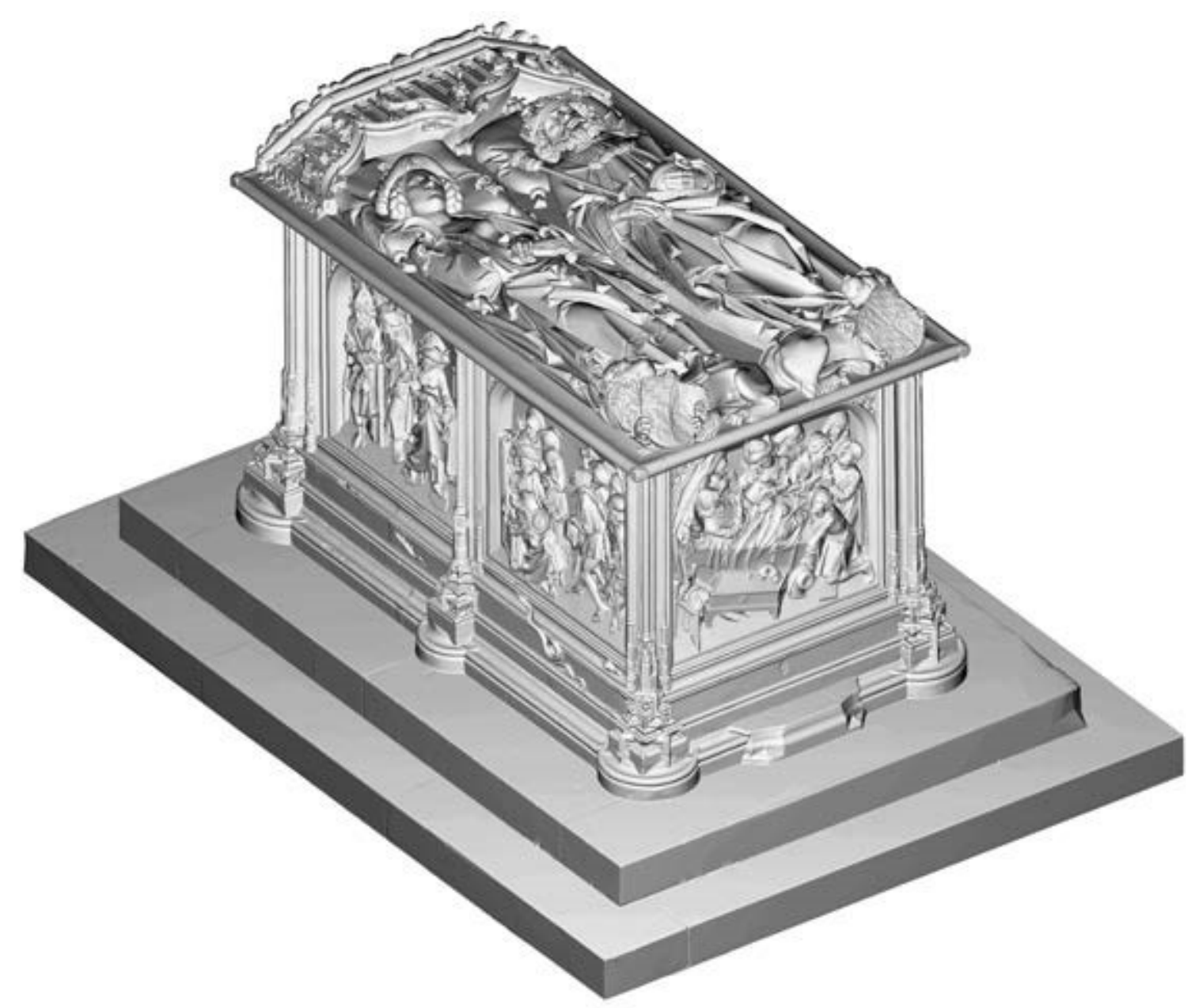

Abb. 1: 3D-Modell des Bamberger Kaisergrabs. Isometrische Darstellung

\section{Einführung}

Die Erstellung von 3D-Modellen bedeutender Kulturgüter hat sich zu einem allgemein gängigen Dokumentationswerkzeug entwickelt. Besonders in den letzten Jahren wurden immer mehr Low-CostTechnologien und Open-Source-Softwarelösungen entwickelt, die es erlauben mit geringem Aufwand Objekte zu digitalisieren und die Daten zu bearbeiten.

In großen Forschungsprojekten wurden sogar ganze Scanstraßen entwickelt, mit denen Museumssammlungen in kürzester Zeit - wortwörtlich - am Fließband erfasst werden können. ${ }^{255}$ Die Gründe für eine dreidimensionale Erfassung differieren dabei mitunter gewaltig; Neben wissenschaftlichen Fragestellungen, zu deren Klärung eine detaillierte Oberflächendokumentation benötigt wird, über die Erstellung von verzeichnungsfreien Orthofotos als Grundlage für Kartierungen jeglicher Art, bis hin zur web-fähigen Präsentation der Objekte auf den Internetseiten der Museen und Sammlungen. Die nahezu vollumfängliche Oberflächendokumentation eines Objektes durch sein

\footnotetext{
${ }^{255}$ Fuhrmann, Constanze / Santos, Pedro / Fellner, Dieter: Cultlab3D: Ein mobiles 3D-Scanning Szenario für Museen und Galerien, in: EVA Berlin 2014, Elektronische Medien \& Kunst, Kultur und Historie, hg. v. Bienert, Andreas / Hemsley, James / Santos, Pedro, Darmstadt/ Berlin, 2014, S. 106-109.
} 
digitales Abbild wird besonders bei gefährdeten Kulturgütern als großer Vorteil gesehen und dient ebenfalls häufig als Begründung für die Erstellung eines 3D-Modells. Einzelne Institutionen gehen sogar noch etwas weiter und lassen sich durch die immer besseren und höher auflösenden 3DDokumentationstechniken dazu verleiten den digitalen 3D-Datensatz als möglichen Ersatz für ein Original anzusehen:

„Bei einem Verlust des Originals sind durch die fotorealistischen 3D-Modelle noch Abbild und Form verfügbar und der Kontext nachhaltig begreifbar. Mithilfe dieser digitalen „3D-Konservierung“ bleiben Objekte für künftige Generationen erhalten. “256

Eine Aussage, die durchaus kritisch zu sehen ist. Vielmehr sollten die 3D-Modelle eher als eine digitale Erinnerung an das Original zum Zeitpunkt der Erfassung ${ }^{257}$ oder als eigenständiges digitales Kulturerbe verstanden werden.

\section{D-Dokumentation des Bamberger Kaisergrabs}

2016 erfolgte im Rahmen der Abschlussarbeit von Julia Trautwein ${ }^{258}$ im Masterstudiengang Denkmalpflege der Universität Bamberg die dreidimensionale Dokumentation des Kaisergrabs im Dom zu Bamberg. Das Hochgrab (Abb. 1) des heiliggesprochenen Kaiserpaares Heinrich II. und Kunigunde wurde zwischen 1499 und 1513 von Tilman Riemenschneider gefertigt. Es zeigt an den Seitenflächen der Tumba Bildreliefs mit Legendenszenen aus dem Leben sowie eine lebensgroße Darstellung des Kaiserpaares auf der Deckplatte. ${ }^{259}$ Die Vermessung erfolgte auf Anregung der 3D-Arbeitsgruppe des Bayerischen Landesamts für Denkmalpflege ${ }^{260}$ und des Erzbistums Bamberg. Die Kernfragestellung der Abschlussarbeit stellte der Vergleich verschiedener Scantechnologien dar, zudem sollte das Kaisergrab umfassend dokumentiert werden, um die 3D- Daten anschließend beispielsweise im Rahmen von Ausstellungen verwenden zu können.

\footnotetext{
${ }^{256}$ Fuhrmann, Constanze / Santos, Pedro / Fellner, Dieter: 3D-Massendigitalisierung - ein Meilenstein für die museale Nutzung, in: Museumskunde, Bd. 80, H. 1, 2015, S. 58-61.

${ }^{257}$ Analog zu der Aussage von Prof. Dr. Andreas Georgopoulos (NTUA, Athen, Griechenland und Präsident des ICOMOS Scientific Commitee on Heritage Documentation (CIPA): „[...] 3D Archives just preserve a memory [...]“ im Rahmen der Panel Session „3D-Mass Digitization - Future Trends, Challenges and Opportunities“ am 02.03.2017 bei der „3D ARCH - 3D Virtual Reconstruction and Visualization of Complex Architectures“ 01.03.03.2017, Nafplio, Griechenland.

${ }^{258}$ Trautwein, Julia: Archivfähige 3D-Modellierung komplexer Oberflächen am Beispiel des Kaisergrabs im Bamberger Dom, unpublizierte Abschlussarbeit im Masterstudiengang Denkmalpflege an der Universität Bamberg, 2016.

${ }^{259}$ Diemer, Dorothea: Kaisertumba, in: hg. v. Exner, Mathias: Die Kunstdenkmäler von Bayern, Regierungsbezirk Oberfranken, IV, Die Kunstdenkmäler von Oberfranken, Stadt Bamberg, Domberg, 1. Das Domstift, Teil 2: Ausstattung, Kapitelsbauten, Domschatz, Bd. IV, Stadt Bamberg Bd. 2.1/2, 2015, S. 1224 - 1251.

${ }^{260}$ Die 3D-Arbeitsgurppe am Bayerischen Landesamt für Denkmalpflege wurde 2013 gegründet, ihre Mitglieder sind: Leiter der Arbeitsgruppe Dr. Martin Mach (BLFD), Dr. Markus Hundemer (BLFD), Dipl. Rest. Jens Wagner (BLFD), Prof. Jörg Maxzin (TH Deggendorf), Prof. Rainer Drewello (Universität Bamberg) und Max Rahrig M.A. (Universität Bamberg).
} 
Die handwerkliche und künstlerische Ausarbeitung der Oberflächen sind von herausragender Qualität. ${ }^{261}$ Trotz der Relieftiefe von lediglich maximal 7,5 cm wird eine einmalige Tiefenwirkung und Plastizität der Bilddarstellungen erzielt. Das 2,48 x 1,54 x 1,59 m (LxBxH - ohne Sockel) messende Kaisergrab befindet sich heute in einer Nische am Ende des Mittelschiffs zwischen den Aufgängen zum Ostchor. Aufgrund seiner Lage, den Lichtverhältnissen und dem umlaufenden Gitter lassen sich viele Bereiche der Grablege nur schwer von den Besuchern betrachten, wodurch viele Details und die gestalterische Brillanz der Reliefs kaum zur Geltung kommen. Besonders die Szene „Heinrich auf dem Sterbebett“ (Abb. 2) auf der Ostseite der Tumba liegt dauerhaft im Schatten und geht in seiner Wirkung nahezu unter. Die Deckplatte ist für die überwiegende Mehrheit der Besucher nicht zu betrachten. Lediglich im Rahmen von Führungen wird Zugang auf den Ostchor gewährt, wodurch ein Blick auf die filigran gearbeiteten Figuren, den feingliedrigen Baldachin und den wappenschildhaltenden Löwen zu Füßen des Kaiserpaares ermöglicht wird (Abb. 3).

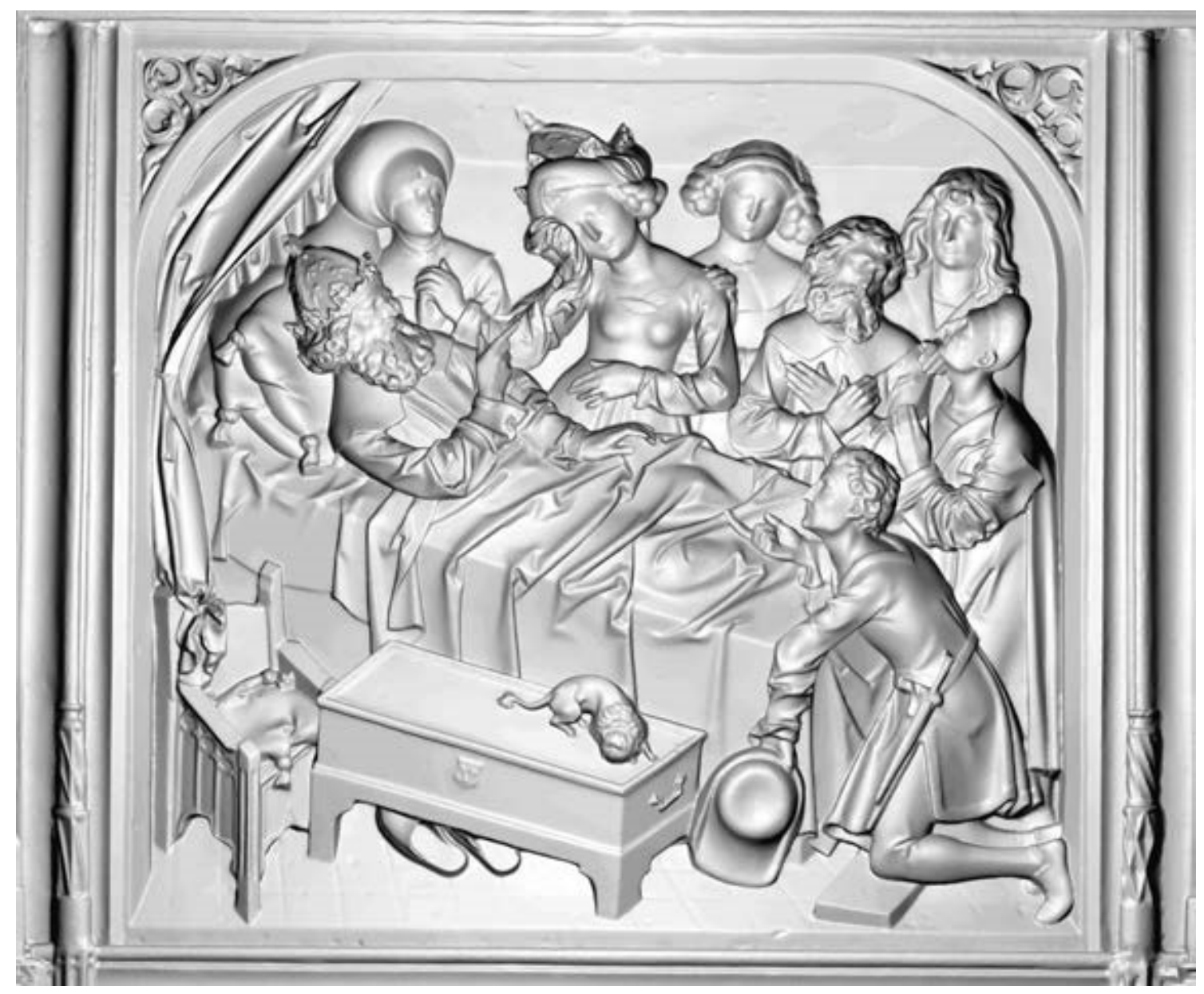

Abb. 2: „Heinrich auf dem Sterbebett“. Ansicht der regulär im Schatten liegenden Reliefplatte an der Ostseite des Kaisergrabs

${ }^{261}$ Vgl. Diemer, Dorothea 2015 (wie Anm. 5), S. 1232. 


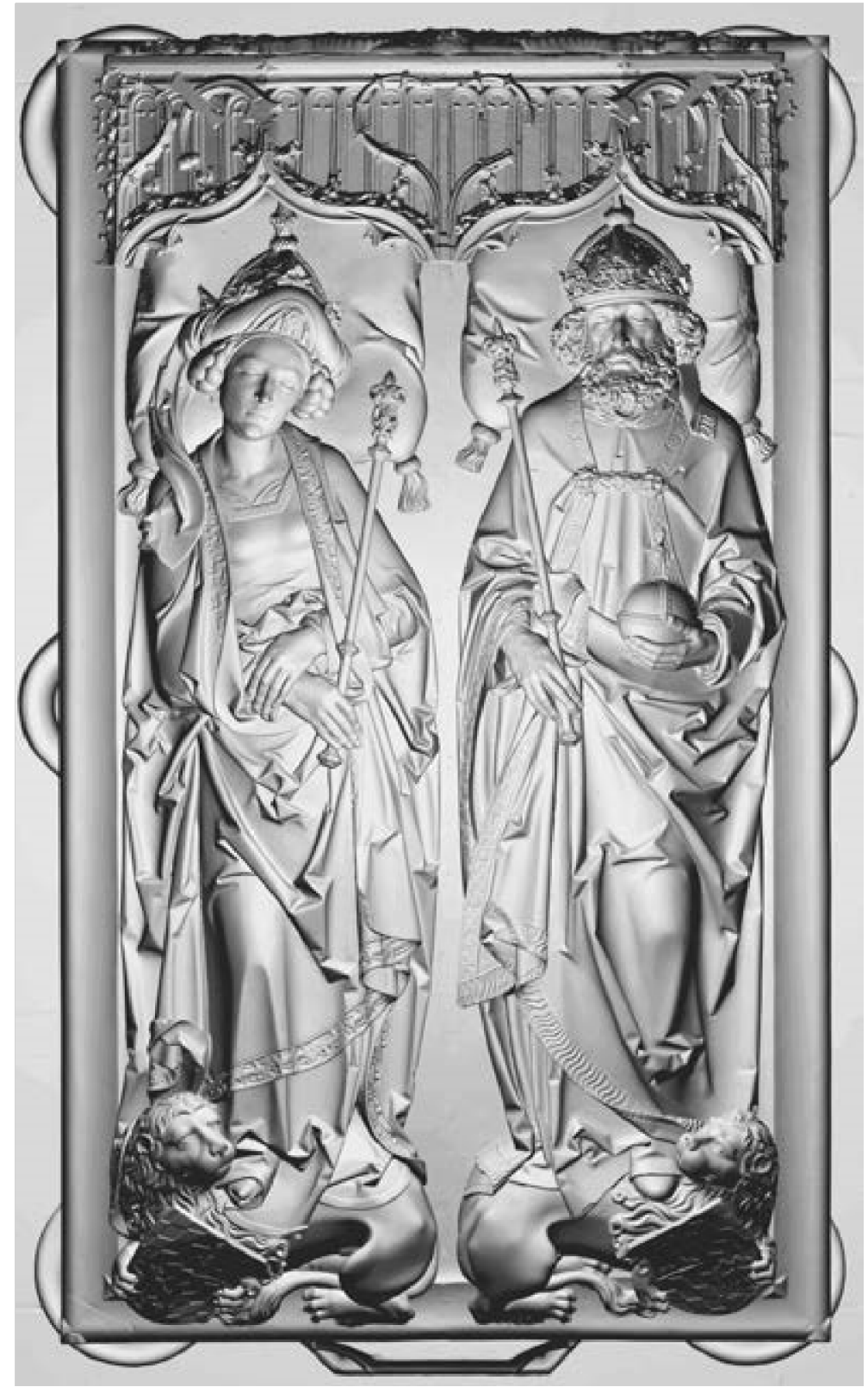

Abb. 3: Aufsicht auf die reich verzierte Deckplatte des Grabmals

Sowohl für die Präsentation der Details für die Besucher aber auch für die Erstellung eines Plansatzes zur restauratorischen Dokumentation der Oberflächen war eine hochauflösende Vermessung mittels Detailscanner im Submillimeterbereich notwendig. Besonders aufgrund der spiegelnden und polierten Oberfläche der Deckplatte und den filigranen Hinterschneidungen im Bereich der Reliefplatten aus Alttertiär-Lithothamnienkalkstein (Algenknollenkalk) ${ }^{262}$ fiel die Wahl auf ein Streifenlichtscansystem mit einer Auflösung von etwa 0,5 mm. Die mit einem Steinbichler Comet L3D erhobenen Daten wurden zusätzlich mit hochauflösenden Fotos fotorealistisch texturiert. Im Endergebnis liegt nun eine umfassende Dokumentation des Kaisergrabes mit nahezu allen Oberflächendetails wie Bearbeitungsspuren, Fassungsresten und Vergoldungen (Abb. 4) vor.

262 Laut Angabe in: Diemer, Dorothea 2015 (wie Anm. 5), S. 1232. 


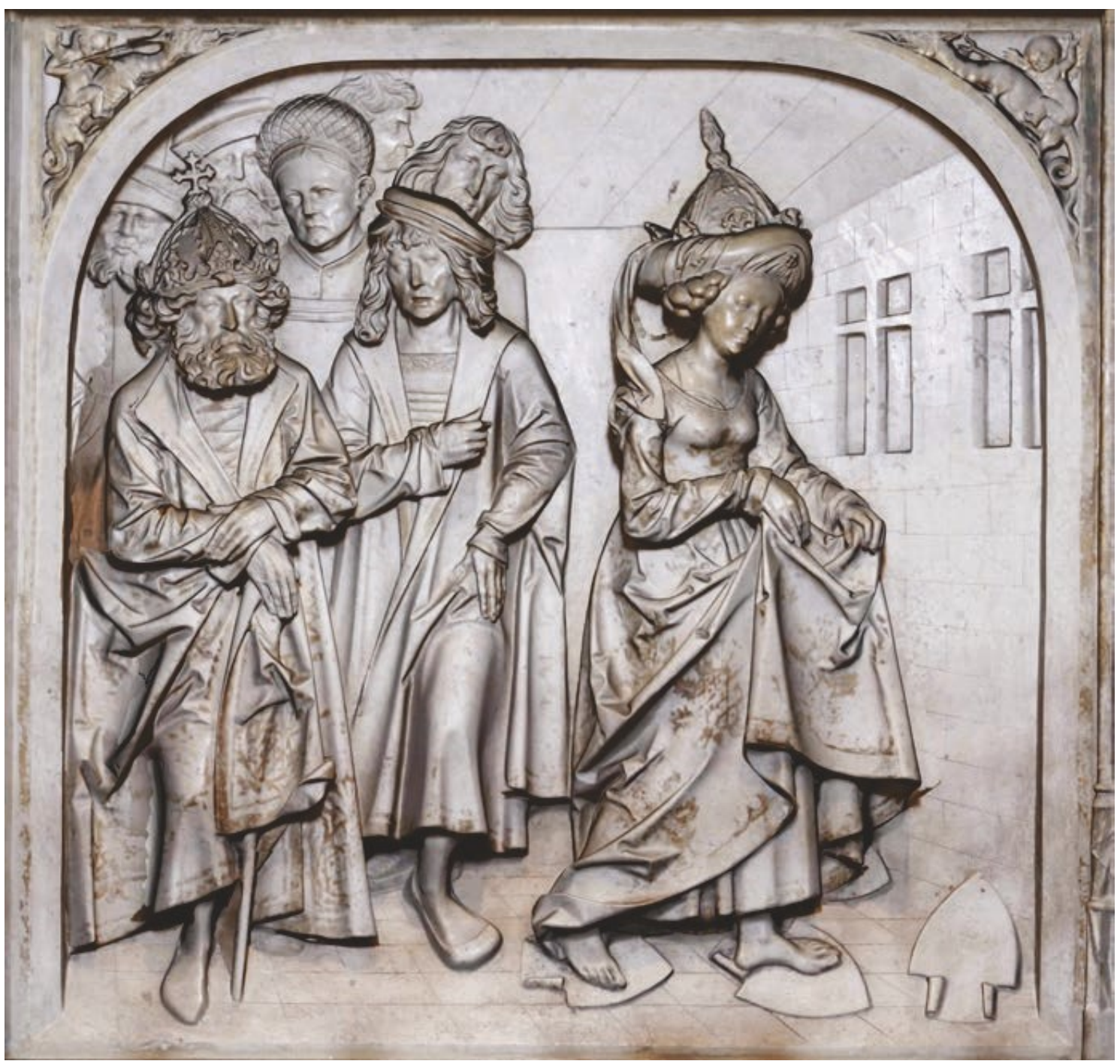

Abb. 4: Reliefplatte mit Darstellung des „Pflugscharwunders“. Fotorealistisch texturiertes 3DModell. Deutlich erkennbar sind die Goldapplikationen auf den Gewändern des Kaiserpaares.

Güte, Qualität und vielseitige Nutzbarkeit solcher Digitalisate machen verständlich, warum 3D-Modelle als eigenständiges digitales Kulturerbe definiert werden sollten. Dadurch entstehen aber auch Pflichten im Umgang mit den Daten, es gilt das digitale Erbe zu schützen und zu bewahren, wie es bereits 2003 in der "Charta zur Bewahrung des digitalen Kulturerbes“263 von der UNESCO definiert wurde. Doch was genau passiert mit den 3D-Modellen nach ihrer Anfertigung und nach der Erstellung von CAD-Plänen und Ansichten? Wie genau erfolgt die Bewahrung der 3D-Daten für kommende Generationen?

Bisher werden die Daten häufig auf DVDs, USB-Sticks oder Festplatten in frei gewählten Formaten gespeichert und den Forschungseinrichtungen, Museen, Sammlungen oder Landesämtern übergeben. Dort mangelt es mitunter an der notwendigen Ausstattung und Software zur Betrachtung der Daten

263 UNESCO: Charta zur Bewahrung des digitalen Kulturerbes, Inoffizielle deutsche Arbeitsübersetzung der UNESCO-Kommissionen Deutschlands, Luxemburgs, Österreichs und der Schweiz, 2003, www.unesco.de/ infothek/dokumente/unesco-erklaerungen/charta-zur-bewahrung-des-digitalen-kulturerbes.html (19.03.2017). 
und somit auch an Erfahrung im Umgang mit 3D-Modellen. Somit droht die Gefahr, dass die Datenträger in Schubladen lagern und in Vergessenheit geraten. Nach wenigen Jahren lassen sich diese Datenträger im schlimmsten Fall nicht mehr lesen, wodurch eine umfassende Dokumentation für kommende Generationen hinfällig wird: 'Sadly, without careful planning, many of our digital efforts will not outlive the heritage they are meant to record and protect. ${ }^{264}$

\section{Online Kulturportale als digitale Archive}

In den letzten 10 bis 15 Jahren wurden verschiedene Lösungsansätze für eine Archivierung der 3DDaten oder generell digitaler Daten historischer Objekte entwickelt. Im Kulturgutsektor handelt es sich hierbei besonders um webbasierte Kulturportale, wie etwa CyArk, Europeana oder Bavarikon.

CyArk wurde 2003 als Non-Profit-Organisation mit dem Ziel, Denkmäler durch 3D-Laserscanning zu dokumentieren und archivieren, gegründet. Die Archivierung der Objekte erfolgt auf einem zentralen Server in den USA. ${ }^{265}$ Je nach Vorgabe des Eigentümers sind die Daten online frei oder auf Anfrage für Wissenschaft und Forschung zugänglich. ${ }^{266}$

2007 wurde im Rahmen der Initiative Digitale Bibliotheken eine europaweite digitale Bibliothek (Europeana) geschaffen. Sie hat das Ziel wissenschaftliches und kulturelles Erbe, wie Fotografien, Bücher, Karten, Filme und Museumsobjekte online verfügbar und so einem großen Kreis an Anwendern einfach und schnell zugänglich zu machen. ${ }^{267}$ Seit Ende 2008 ist das Kulturportal online nutzbar. ${ }^{268}$

Bavarikon ist ein 2012 eingerichtetes Kulturportal zur webbasierten Präsentation bayerischer Kulturobjekte, welches an der Bayerischen Staatsbibliothek angesiedelt ist. ${ }^{269}$ Die bereitgestellten

\footnotetext{
${ }^{264}$ Addison, Alonzo: The Vanishing Virtual. Safeguarding heritage's endangered digital record, in: New Heritage. New media and cultural heritage, hg. v. Kalay, Yehuda / Kvan, Thomas / Affleck, Janice, London, New York, 2008, S. 27-39.

265 Kacyra, Ben: CyArk 500 - 3D Documentation of 500 Important Cultural Heritage Sites, in: Photogrammetric Week `09, hg. v. Fritsch, Dieter, Heidelberg, 2009, S. 315-320.

${ }^{266}$ www.cyark.org/data-use-policy (15.03.2017).

${ }^{267}$ Vgl. Woldering, Britta: Europeana: Die Europäische Digitale Bibliothek - Entwicklungen und Perspektiven, in: Zeitschrift für Bibliothekswesen und Bibliographie (ZfBB), Bd. 55, 2008, S. 33 und Scholz, Henning: Europeana Digitale Dienstleistungs-Infrastruktur für Europas Kulturerbe, in: Handbuch Kulturportale, hg. v. Euler, Ellen / Hagedorn-Saupe, Monika / Maier, Gerald / Schweibenz, Werner / Sieglerschmidt, Jörn, Berlin / Boston 2015, S. 125-132.

${ }^{268}$ Europeana, Die digitale Bibliothek Europas, ist online, in: ZfBB, Bd. 56, 2009, S. 44.

${ }^{269}$ Ceynowa, Klaus/ Kellner, Stephan: Das bayerische Kulturportal bavarikon - digital, vernetzt, spartenübergreifend, in: Bibliotheksmagazin, H. 1, 2014, S. 8-14.
} 
Daten umfassen beispielsweise Fotos, Archivalien, Videos, Handschriften und 3D-Modelle sowie 3DRekonstruktionen. ${ }^{270}$ Bis 2015 wurden bereits über 200.000 Objekte in das Kulturportal eingepflegt. ${ }^{271}$

\section{Unabhängige Archivierung von 3D-Daten}

Die vorgestellten Kulturportale bieten großes Potenzial zum Erhalt, zur Verbreitung und Erstellung von digitalem Kulturgut. Besonders im Bereich der dreidimensionalen Dokumentation leisten diese drei Kulturportale einen großen Beitrag zum stetig wachsenden Datenpool bei: CyArk hat seinen Länder unabhängigen Schwerpunkt ausschließlich im Umgang mit 3D-Daten, für Europeana wurden zur Einbindung und gezielten Erstellung von 3D-Daten eigens EU-Forschungsprojekte realisiert, ${ }^{272}$ Bavarikon bietet die 3D-Vermessung herausragender bayerischer Kulturobjekte als kostenlosen Service an. ${ }^{273}$

Neben der Verbreitung und Aufbewahrung der 3D-Daten in Kulturportalen sind aber auch die Museen, Sammlungen und Landesämter in der Pflicht eigenständige Archive zu betreiben und unabhängig von der Entwicklung und Förderung Dritter die Dokumentation unseres kulturellen und digitalen Erbes langfristig zu bewahren. Die Hauptanforderung an eine längerfristige Archivierung digitaler Daten lässt sich dabei wie folgt beschreiben: „Im Sinne der Langzeitarchivierung stellen Informationen den zu erhaltenden „Wert" dar. Informationen, die durch digitale Objekte repräsentiert werden, sind bedroht durch Einbußen in ihrer Integrität, Authentizität und Vertraulichkeit sowie den gänzlichen Verlust der Verfügbarkeit und Nutzbarkeit. ${ }^{274}$

Die Integrität steht dabei für die Unveränderbarkeit der Daten. Durch die Authentizität wird die Echtheit der Daten und die Nachweisbarkeit der Ersteller, Urheber oder Autoren beschrieben. Die Vertraulichkeit beschreibt den Schutz vor Datenmissbrauch seitens Dritter, wie beispielsweise eine

\footnotetext{
${ }^{270}$ Ceynowa, Klaus / Sepp, Florian: Das Landesportal bavarikon in kulturpolitischer Perspektive, in: Bibliotheksmagazin, H. 2, 2016, S. 13-16.

${ }^{271}$ Ceynowa, Klaus / Kellner, Stephan: Das bayerische Kulturportal bavarikon - digital, vernetzt, spartenübergreifend, in: Handbuch Kulturportale, hg. v. Euler, Ellen / Hagedorn-Saupe, Monika / Maier, Gerald / Schweibenz, Werner / Sieglerschmidt, Jörn, Berlin / Boston 2015, S. 292-300.

272 D'Andrea, Andrea: Providing 3D Content to Europeana, in: CAA2015. Keep the Revolution going. Proceedings of the 43rd Annual Conference on Computer Applications and Quantitative Methods in Archaeology, hg. V. Campana, Stefano / Scopigno, Roberto / Carpentiero, Gabriella / Cirillo, Marianna, Oxford, 2016, S. 269-274, Gonizzi Barsanti, S. and Guidi, G.: 3D Digitization of Museum Content within the 3DICONS Project, in: ISPRS Ann. Photogramm. Remote Sens. Spatial Inf. Sci., II-5/ W1, 2013, S. 151-156, doi:10.5194/isprsannals-II-5-W1-151-2013.

${ }^{273}$ Ceynowa, Klaus / Kellner, Stephan / Sepp, Florian: Bavarikon - Eine digitale Plattform auch für Museen, in: Museum Heute, H. 48, 2015, S. 52-56 und Horn, Felix: Die 3D-Digitalisierung im Kulturportal bavarikon, in: Museum Heute, H. 50, 2016, S. 80-83.

${ }^{274}$ Nestor-Handbuch. Eine kleine Enzyklopädie der digitalen Langzeitarchivierung. Version 2.3, hg. v. Neuroth, H. / Oßwald, A. / Scheffel, R. / Strathmann, S. / Huth, K., 2010, S. 94, http://nestor.sub.unigoettingen.de/handbuch/ (27.03.2017).
} 
unerlaubte Verwendung der Daten für wirtschaftliche Zwecke oder unlizenzierte Vervielfältigung und Vermarktung durch 3D-Druck. Die Verfügbarkeit steht für die Zugänglichkeit der digitalen Daten. ${ }^{275}$

Im Zuge der dreidimensionalen Dokumentation des Bamberger Kaisergrabs wurde innerhalb der 3DArbeitsgruppe des BLfD die Frage nach einer dauerhaften Archivierung des Datensatzes und seiner Ergebnisse diskutiert. Den Beteiligten war dabei von Anfang an wichtig hier keine Insellösung für diesen einen Datensatz zu erstellen, sondern vielmehr eine vielseitige, unabhängige und einfach nutzbare Lösung zu finden, um auch künftig 3D-Daten bedeutender Kulturgüter in einer einheitlichen Struktur zu archivieren. Großes Potenzial wird in einer standardisierten Ablagestruktur in Kombination mit der GlassMasterDisc (GMD) gesehen. Die GMD wird bereits erfolgreich im Archiv des BLfD genutzt, um den Bestand historischer Fotos und Negative digital zu archivieren. ${ }^{276}$

\section{Die GlassMasterDisc (GMD)}

Bei der GlassMasterDisc (GMD) handelt es sich - vereinfacht beschrieben - um eine DVD aus Glas. Die zu speichernden Informationen werden hierbei als Vertiefungen in die Glasoberfläche der GMD eingearbeitet. Aufgrund der extrem reinen Rohstoffe bei der Herstellung der Gläser sind die Disks äußerst beständig gegenüber Feuchtigkeit, Temperatur und besonders gegenüber magnetischer oder kosmischer Strahlung, zudem haben sie eine nahezu unbegrenzte Lebensdauer. Durch die hohe Beständigkeit entfällt eine aufwändige Datenpflege, wie sie bei weniger beständigen Datenträgern wie normalen DVDs, USB-Sticks, Magnetbändern oder Festplatten notwendig wäre. Die Daten müssen vom Hersteller (Syylex AG) in die Disk eingearbeitet werden. Nach der Erstellung sind die GMDs mit jedem DVD- oder Blu-ray-Laufwerk lesbar. Sollte das DVD-Format im Laufe der technologischen Entwicklung abgelöst werden, ist durch den öffentlich zugänglichen ECMA-Standard für optische Datenträger sichergestellt, dass auch künftig Lesegeräte zur Not einfach nachgebaut werden könnten. ${ }^{277}$ Die Speicherkapazität der GMD liegt in der neuesten Ausführung bei $10 \mathrm{~GB} .{ }^{278}$ Besonders im Falle von 3DDaten ist in der Regel mit sehr hohen Dateigrößen zu rechnen, wodurch die Kapazität sehr schnell erschöpft ist. Im Falle des Kaisergrabs wurden für die Archivierung zwei GMDs benötigt, eine für die Rohdaten und eine für die bearbeiteten 3D-Modelle und fertigen CAD-Pläne. ${ }^{279}$

\footnotetext{
${ }^{275}$ Vgl. Nestor-Handbuch 2010 (wie Anm. 20), S. 94.

${ }^{276}$ Vgl. Hundemer, Markus im Interview mit Eberling, Friederike / Gleiss, Julia: Digitale Dokumentation. Gegen digitales Vergessen, in: Restauro, H. 8, 2015, S. 28-30.

${ }^{277}$ Sommermeyer, Christian: Innovative Langzeitarchivierung mit der Glassmasterdisc, in: EVA Berlin 2014, Elektronische Medien \& Kunst, Kultur und Historie, hg. v. Bienert, Andreas / Hemsley, James / Santos, Pedro, Darmstadt/Berlin, 2014, S. 209-210.

${ }^{278}$ Vgl. www.syylex.com (20.03.2017).

${ }^{279}$ Mit Ausblick auf die Speicherkapazitäten heutiger Blu-ray-Discs von über $100 \mathrm{~GB}$ ist bei fortschreitender Entwicklung zu erwarten, dass es auch bei der GMD nicht allzu lange dauern wird, bis Speicherkapazitäten in dieser Größe erreicht werden können.
} 


\section{Eine standardisierte Ablagestruktur}

Die GMDs sollen nun auch genutzt werden, um die 3D-Daten bedeutender bayerischer Kulturschätze zu archivieren. Innerhalb der 3D-Arbeitsgruppe wurde daher eine einheitliche Ablagestruktur zur Archivierung der Daten erarbeitet. Hierbei war es wichtig, die Struktur möglichst übersichtlich und benutzerfreundlich zu halten, so dass sie auch von Dritten zur Vorbereitung der zu archivierenden Daten schnell angewendet werden kann. Neben der Ausarbeitung einer einheitlichen Ablagestruktur wurden zudem einheitliche Dateiformate festgelegt, die im Rückblick auf die letzten 10 bis 15 Jahre als beständig erachtet werden und aufgrund ihrer weiten Verbreitung von nahezu jeder gängigen 3DSoftware lesbar sind.

Die Ablagestruktur basiert auf vier grundlegenden Säulen der Dokumentation: Einem Report als steckbriefartiger Kurzbeschreibung des Projektes, den Rohdaten, den Ergebnisdaten und einer bildbasierten Dokumentation der Objekte für eine schnelle Sichtung der Projektinhalte.

\section{Der Report}

Der Report soll alle grundlegenden Information für die zu archivierenden Datensätze enthalten. Hierzu wurde eine Vorlage erarbeitet, aus der die Kerninformationen ${ }^{280}$ oder die bekannten fünf W-Fragen (wer, was, wann, für wen, wie) auf einen Blick ersichtlich sind (Abb. 5). So sollen neben dem Projekttitel und dem Datum der Erstellung des Datensatzes auf der ersten Seite zunächst die Kontaktdaten des Auftraggebers und des Auftragnehmers mit Anschrift, Logo, Ansprechpartner, Telefonnummer und EMailadresse angegeben werden. Darauf folgt eine kurze Objektbeschreibung, welche den Typ bzw. den Eigennamen des Objektes enthält, die Datierung (sofern bekannt), Größe sowie die Materialart des Objektes. Unterhalb der Kurzbeschreibung folgen Angaben über den Standort und ggf. die Inventarnummer.

Neben den objektspezifischen Informationen sind auch Angaben zu der verwendeten Dokumentationstechnik mit genauer Typenbezeichnung, die Namen der Bearbeiter während der Datenaufnahme und der Nachbearbeitung, sowie das Datum der Vermessung und der Zeitraum der Nachbearbeitung anzugeben. Ferner sind die Dateiformate der Rohdaten und der finalen Daten anzugeben.

Informationen über den Grund der Datenaufnahme mit Fragestellung und geplanten Anforderungen an das 3D-Modell sind ebenfalls essentiell, da sich aus diesen Informationen die Qualität und Verwendbarkeit für weitere Arbeiten entnehmen lässt. So sind Datensätze, die rein für eine WebPräsentation erstellt wurden, in der Regel nur bedingt für eine Schadenskartierung oder ein 3DMonitoring nutzbar. Für die Web-Präsentation sollen die Modelle möglichst geringe Dateigrößen

\footnotetext{
${ }^{280}$ Vgl. Addison, Alonzo 2008 (wie Anm. 5), S. 39.
} 
aufweisen, wodurch die Geometrie und z.T. auch Farbinformation stark reduziert sind. Für ein 3DMonitoring sind diese finalen Daten daher kaum verwendbar, so dass ggf. eine erneute Verarbeitung basierend auf den Rohdaten erfolgen müsste. Andererseits ließen sich 3D-Drucke, für eine museale Präsentation, aus den webgeeigneten Datensätzen vermutlich ohne weitere Bearbeitung erstellen.

Die erste Seite des Reports sollte zudem neben der textbasierten Beschreibung des Projektes auch ein bis zwei aussagekräftige Abbildungen der Daten enthalten. Auf der zweiten und möglichen folgenden Seiten können ggf. zusätzliche Abbildungen folgen, zudem soll hier die Ordnerstruktur der GMD mit allen abgelegten Dateien, mit Angabe des Dateiformats und einer kurzen Beschreibung folgen (Abb. 5). Die Kurzbeschreibung der einzelnen Dateien soll dabei Angaben zum Bearbeitungsstand (Rohdaten/aufbereitete Daten), der Oberflächenauflösung, mögl. Farbinformationen etc. enthalten. Im Bereich der bildbasierten Dokumentation sind zudem die DPI und bei verzeichnungsfreien Abbildungen (Orthofotos) das Pixelmaß in Millimetern anzugeben. Der Report soll im Dateiformat PDF/A auf der GMD gespeichert sein: Zusätzlich wird dem Datenträger ein Ausdruck auf säurefreiem, beständigem Papier beigefügt, so dass auch ohne Auslesen des Datenträgers der zu erwartende Inhalt schnell gesichtet werden kann.
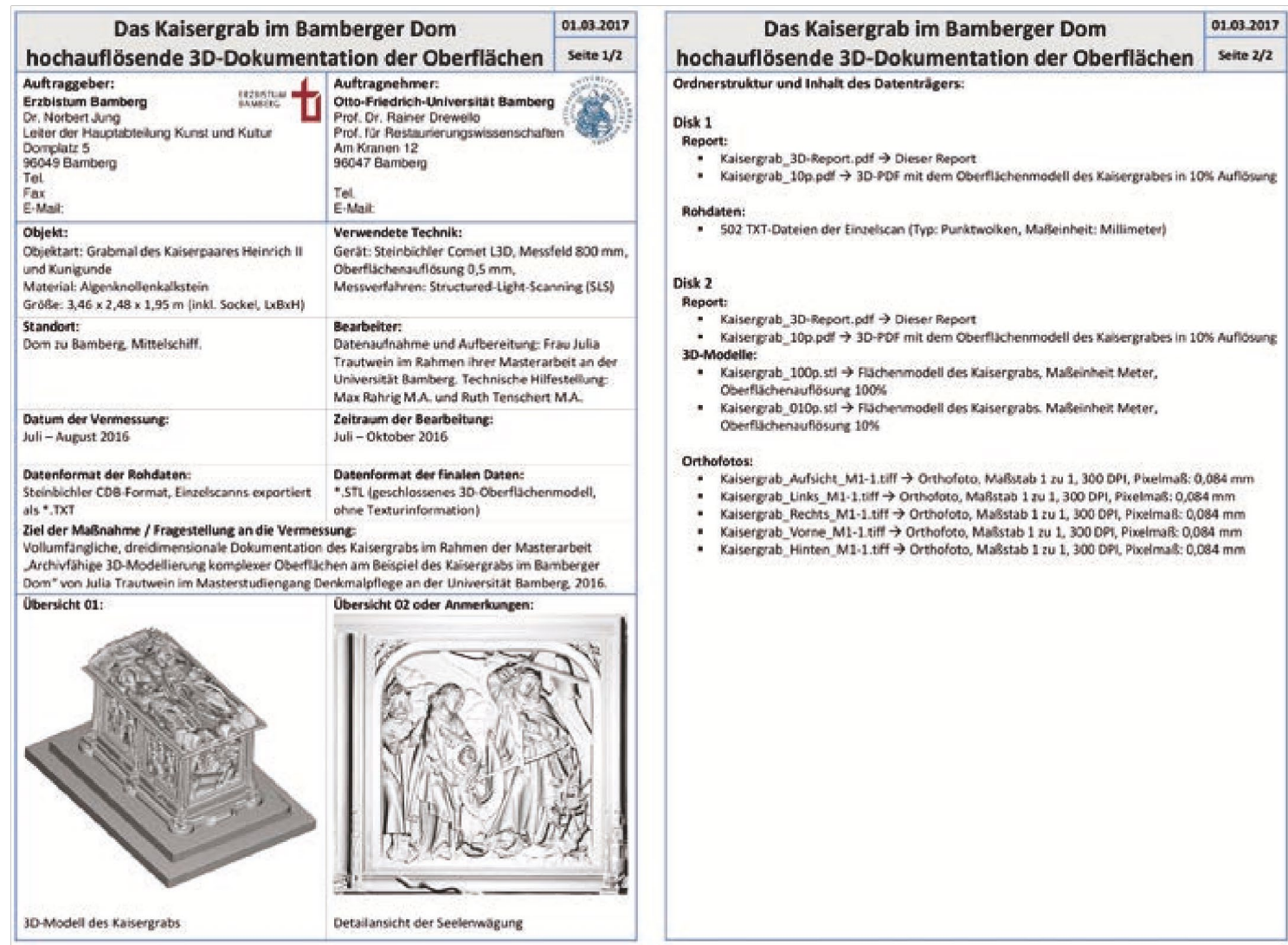

Abb. 5: Report zur 3D-Dokumentation des Kaisergrabs im Dom zu Bamberg 


\section{Einheitliche Dateiformate für 3D-Daten}

Bedingt durch die jeweilige Messtechnik lassen sich, wie am Beispiel des Bamberger Kaisergrabes zu sehen ist (Abb. 6), nicht alle Bereiche eines Objektes lückenlos mittels 3D-Scanning erfassen. Im Rahmen der Nachbearbeitung und Aufbereitung der 3D-Modelle werden die Daten, je nach Fragestellung, immer in einer gewissen Weise verändert, manipuliert oder interpretiert. So werden die Einzelscans während der Triangulation, also dem Überführen von einer Punktwolke aus Einzelscans in ein zusammenhängendes Oberflächenmodell, bereits gefiltert und verändert. Hier werden beispielsweise scannerspezifische Messfehler, so genanntes Rauschen oder durch die Überlagerung vieler Einzelscans entstandene redundante Daten, also mehrfach vorliegende, identische Punkte, ausgeglichen oder herausgefiltert. In der anschließenden Weiterverarbeitung werden dann Fehlstellen interpoliert oder die Daten in ihrer Auflösung reduziert, um webfähige Dateigrößen zu erhalten oder sie einfacher im 3D-Drucker verarbeiten zu lassen. Daher ist es wichtig auf den GMDs sowohl die Ergebnisse als auch die Rohdaten der 3D-Vermessung zu archivieren, um eine möglichst umfassende Nutzbarkeit zu gewährleisten.
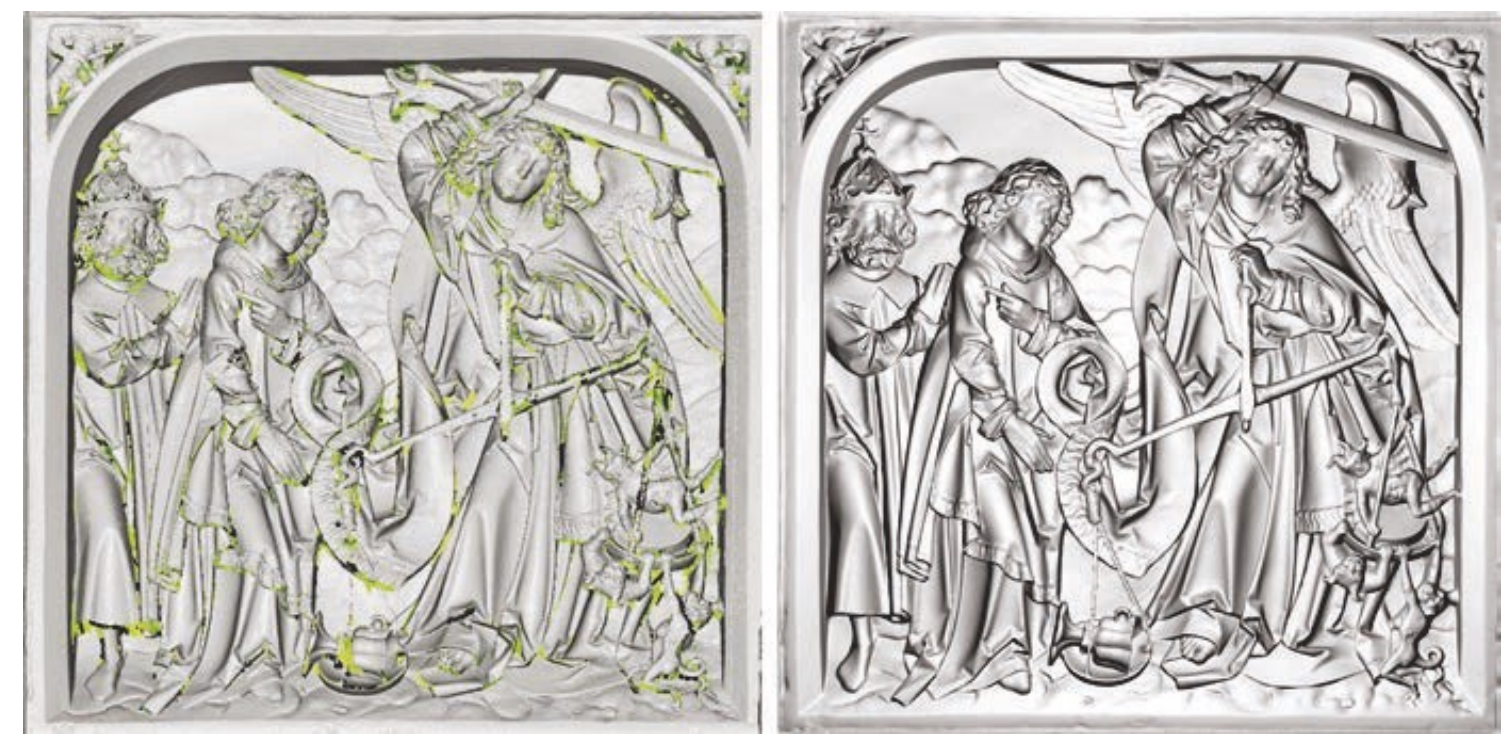

Abb. 6: Relief der „Seelenwägung“: Unbearbeitete Rohdaten (links), gelb-grün sind Fehlstellen und Löcher dargestellt und nachbearbeitetes 3D-Oberflächenmodell (rechts) bei dem u.a. die Löcher geschlossen wurden

Da jeder Hersteller und jede weiterführende Bearbeitungssoftware ihre eigenen Dateiformate verwendet, diese häufig nicht zwischen verschiedenen Programmen beliebig ausgetauscht werden können und womöglich bereits nach kurzer Zeit bspw. durch ein Softwareupdate oder einer Insolvenz des Herstellers nicht mehr unterstützt werden und lesbar sind, müssen für die Archivierung Datenformate gewählt werden, die hard- und softwareunabhängig verarbeitet werden können. Zudem sollten diese Datenformate unabhängig derzeit verwendeter Programmiersprachen gewählt werden. Für die Auswahl der vorgeschlagenen einheitlichen Formate wurden daher rein textbasierte 
Dateiformate gesucht. Diese lassen sich durch einfache Texteditoren öffnen, wodurch sich der Dateninhalt auch bei einem Wegfallen der Software durch Informatiker rekonstruieren ließe.

Für die Archivierung der Rohdaten in Form von Einzelscans und Punktwolken haben sich die Formate *.txt, *.xyz und *.las als dienlich erwiesen. Die beiden erstgenannten Formate enthalten für jeden gemessenen Punkt eine Zeile mit Angabe der drei Raumkoordinaten (X-, Y-, und Z-Achse) sowie ggf. Farbwerte in RGB oder die Intensität der Laserreflexion als Grauwert. Das *.las-Format wurde von der ASPRS - The Imaging and Geospatial Information Society - als Standardformat für Laserscan- und LIDAR-Daten definiert, wodurch eine langfristige Nutzbarkeit gewährleistet sein soll. Das Format ist zwar nicht rein textbasiert, ein Vorteil liegt jedoch beispielsweise in einem deutlich geringeren Speicherplatzbedarf. ${ }^{281}$

Die zu Oberflächenmodellen aufbereiteten Daten sollten in den Formaten *.stl, *.obj oder *.wrl archiviert werden. Das *.stl-Format wurde Ende der 80er Jahre von 3D-Systems entwickelt und ist seither die gängigste Schnittstelle zum Austausch von 3D-Oberflächenmodellen. ${ }^{282}$ Der entscheidende Nachteil liegt darin, dass das Format keine Farbinformationen verarbeiten kann, also lediglich die reine Oberflächengeometrie enthält. Sofern der zu archivierende Datensatz Textur-/Farbinformationen enthält, muss daher auf die beiden anderen Formate zurückgegriffen werden. Sowohl das *.obj-, wie auch das *.wrl-Format (oder auch VRML-Format genannt) sind textbasiert und zählen zu den Standardformaten im Umgang mit 3D-Modellen. ${ }^{283}$ Das VRML-Format ist zudem ISO/ICE zertifiziert und war als Standard für webbasierte Präsentation von 3D-Modellen vorgesehen. ${ }^{284}$ Beide Formate können die Farbinformation direkt innerhalb der Datei als Vertexcolor enthalten, bei höher aufgelösten Texturen empfiehlt sich ein Texturemap, bei dem die Farbinformation in einem oder mehreren separaten TIFFs oder JPEGs bereitgestellt wird.

Für eine einfache Betrachtung der archivierten 3D-Daten wird zudem ein 3D-PDF der Daten auf der GMD hinterlegt. Dieses erlaubt ein schnelles Sichten der Daten ohne eine spezielle 3D-Software zu benötigen. Die im PDF enthaltenden 3D-Modelle sind jedoch, systembedingt, in ihrer Auflösung drastisch reduziert.

\footnotetext{
${ }^{281}$ Vgl. ASPRS: LASer (LAS) File Format Exchange Activities, www.asprs.org/committee-general/laser-las-fileformat-exchange-activities.html (27.03.2017).

${ }^{282} \mathrm{Vgl}$. www.3Dsystems.com/quickparts/learning-center/ what-is-stl-file (27.03.2017).

${ }^{283} \mathrm{Vgl}$. für das *.obj-Format: http://www.fileformat.info/ format/wavefrontobj/egff.htm und für das *.wrlFormat: www.web3D.org/standards (beide 27.03.2017).

${ }^{284}$ Das *.wrl-Format wurde inzwischen offiziell vom *.x3D-Format abgelöst. Erfahrungsgemäß ist dieses Format jedoch nach wie vor nicht von allen Programmen lesbar, weshalb am alten Standard festgehalten wird.
} 


\section{Ausblick}

Durch Verwendung der GMD ist die Integrität der Daten gewährleistet, da die Daten unveränderlich in die Oberfläche der Disk eingearbeitet sind. Die hohe Beständigkeit trägt zur Verfügbarkeit und Nutzbarkeit der digitalen Daten bei. Durch die Archivierung der Disks im Tresor des Archivs des BLfD ist die Vertraulichkeit und damit ein Schutz vor Datenmissbrauch gesichert. Der Report beinhaltet alle erforderlichen Metadaten und damit die Informationen zur Sicherung der Authentizität. Durch die Wahl offener und weit verbreiteter Dateiformate wie *.txt, *.las, *.stl, *.obj und VRML (*.wrl) ist die Verfügbarkeit und Lesbarkeit der Daten zumindest vorerst gesichert. Jedoch muss die Veränderung und Entwicklung der Dateiformate regelmäßig verfolgt werden. Da die GlassMasterDisc ein sehr junges Produkt ist, muss auch hier die tatsächliche Beständigkeit und Langlebigkeit in den kommenden Jahren zumindest stichprobenartig überprüft werden. Zudem ist das auf $10 \mathrm{~GB}$ limitierte Datenvolumen vorerst ein ungelöstes Problem für die Archivierung großer Datensätze. Das Problem der Archivierung von 3D-Daten bedeutender Kulturgüter scheint dennoch, mit den offenen Dateiformaten und den Möglichkeiten der GMD, einen guten und wichtigen Schritt weitergekommen zu sein. Neben der Archivierung des Bamberger Kaisergrabs sollen künftig auch Datensätze bereits erfasster bayerischer Kulturgüter wie beispielsweise dem Bamberger Reiter, dem Grabmal Papst Clemens II. aber auch neu zu erfassende Objekte archiviert werden.

\section{Danksagung}

Besonderer Dank gilt Frau Julia Trautwein für die Erfassung und Bearbeitung der 3D-Daten im Rahmen ihrer Abschlussarbeit (Archivierungsfähige 3D-Modellierung komplexer Oberflächen am Beispiel des Kaisergrabs im Bamberger Dom. Unveröffentlichte Masterarbeit am Masterstudiengang Denkmalpflege, Universität Bamberg 2016) sowie der Bamberger Dombauhütte für ihre Unterstützung bei der Digitalisierung des Kaisergrabs. Besonders zu erwähnen sind die Kollegen von der 3DArbeitsgruppe aufgrund der intensiven Zusammenarbeit im Zuge der Definition geeigneter Datenformate, hier besonders Herrn Dr. Martin Mach, Leiter der 3D-Arbeitsgruppe und Herrn Dr. Markus Hundemer, der die Diskussion bzgl. der Archivierung von 3D-Daten überhaupt erst angeregt und uns die GMD als mögliche Lösung präsentiert hat. Herrn Dr. Norbert Jung vom Erzbistum Bamberg und Herrn Generalkonservator Prof. Mathias Pfeil vom BLfD sei an dieser Stelle ebenfalls ausdrücklich gedankt für ihre freundliche Unterstützung und Genehmigung für die Verwendung von Bildmaterial zum Bamberger Kaisergrab. 


\section{Nachtrag zu Publikation 6}

Im Ausblick wurde bereits auf die Problematik der geringen Speichergröße der Glass Master Disk (GMD) und der notwendigen Kontrolle ihrer Langlebigkeit eingegangen. ${ }^{285}$ In den vergangenen zwei Jahren seit Veröffentlichung des Artikels wurde die Herstellung der GMD durch Syylex eingestellt. Ob eine erneute Produktion der GMD wieder aufgenommen wird, bleibt derzeit ungewiss. ${ }^{286}$ Dies zeigt einmal mehr, dass eine Abhängigkeit von Dritten besonders im Umgang mit Daten und Objekten im Kontext des Kulturerbes höchst problematisch ist. Nach aktuellem Stand wird es daher für die Archive von Museen und Landesämtern unumgänglich sein, ihre eigenen IT-Abteilungen mit der Aufgabe der Datensicherung auf geeigneten Serversystemen zu beauftragen und dazu gegebenenfalls überhaupt eine IT-Abteilung einzurichten. Ob eine Auslagerung dieser Aufgabe an große Rechenzentren der Länder oder gar an Dienstleister hier langfristig der richtige Weg ist, wird sich zeigen müssen. Im Sinne der genannten Archivpflicht ${ }^{287}$ und der damit verbundenen Aufgabe der Museen und Landesämter, persönlich für die Integrität und Verfügbarkeit der Daten Sorge zu tragen, wird es unumgänglich sein, zumindest eine Ausführung der digitalen Datensätze auf eigenen Servern der Einrichtung vorzuhalten. Die entwickelte Ablagestruktur mit den empfohlenen Standardformaten und dem Report für eine schnelle Erfassung der Inhalte bildet dabei weiterhin eine fundierte Grundlage für die langfristige Archivierung der 3D-Daten. Die Inhalte des Reports sind dabei bewusst so konzipiert, dass sie von Datenbankensystemen durchsuchbar sind und die enthaltenen Informationen dem von ICOM vorgeschlagenen Standard CIDOC CRM angelehnt sind. ${ }^{288}$

\footnotetext{
285 Rahrig 2017, S. 138.

${ }^{286}$ Nach telefonischer Auskunft von Herrn Elsässer, Fa. Syylex Ag, am 31.07.2018.

${ }^{287}$ Rahrig 2017, S. 134.

288 Dabei handelt es sich um ein vom ICOM International Committee for Documentation (CIDOC) entwickeltes Conceptual Reference Model (CRM), welches als standardisierte Struktur für die Einbindung von Informationen von Kulturerbe Datenbanken übergreifend dient, vgl. <http://www.cidoc-crm.org> letzter Zugriff 17.08.2019.
} 


\section{8. Übergreifende Diskussion}

In den Digitalisierungsstrategien der Bundesrepublik Deutschland und der Europäischen Union wird auch der Umgang mit Kulturgütern thematisiert. In der digital cultural heritage policy ${ }^{289}$ spricht sich die EU dabei deutlich für die Notwendigkeit der Digitalisierung von Kulturgut aus und hat hierzu in den vergangenen Jahren diverse Förderprogramme realisiert und weitere werden geplant. Innerhalb des aktuellen Förderrahmenprogramms Horizon 2020 gab es allein in der Sektion Societal Challenges 6 mehrere Ausschreibungen zu Forschungsprojekten mit einem Gesamtvolumen von insgesamt etwa 40 Millionen Euro zur Entwicklung kosteneffektiver Technologien zur 3D-Digitalisierung von Kulturgut $\left(2014^{290}\right.$ und $\left.2018^{291}\right)$ und der Erstellung virtueller Museen $\left(2016^{292}\right)$.

Für die Bundesrepublik Deutschland sei besonders auf die Förderrichtlinie zu Forschungs- und Entwicklungsvorhaben zur Digitalisierung von Objekten des kulturellen Erbes - eHeritage ${ }^{293}$ des Bundesministeriums für Bildung und Forschung (BMBF) hingewiesen, welches 2019 bereits zum zweiten Mal Projekte zur Erstellung von Digitalisaten von Kulturerbe und ihrer Erschließung fördert. Explizit nicht gefördert werden dabei Maßnahmen der Restaurierung und Konservierung oder Aufbewahrung und Präsentation des Originals. ${ }^{294}$

Aufgrund des föderalen Systems in Deutschland obliegt die Hoheit und Verantwortung über die Kultur generell den einzelnen Bundesländern, sodass diese eigenverantwortliche Herangehensweisen und Lösungen im Rahmen der Digitalisierungsstrategie der BRD entwickeln können und müssen. Für eine bessere Transparenz und Verbreitung der digitalen Inhalte wurde ein Kooperationsprojekt zwischen Bund und Ländern gegründet, die Deutsche Digitale Bibliothek. ${ }^{295}$ In ihr sollen die einzelnen Strategien der Bundesländer gebündelt werden. 2016 wurde hierzu ein Bericht veröffentlicht in dem die bis dato erfolgten und geplanten Strategien und Projekte erläutert wurden. Der Schwerpunkt lag bei allen Bundesländern in der Digitalisierung von Schrift, Ton-, Bild- und Videomaterial. Ein weiterer Fokus auf Museen und Sammlungen wird genannt, aber die Bereitstellung von Bild- und Informationsmaterialien zu den Sammlungsobjekten nicht eingehend behandelt. Lediglich in vier Bundesländern wird die Digitalisierung und Verbreitung musealer Objekte und Denkmäler darüber hinaus konkretisiert. ${ }^{296}$ Von

\footnotetext{
${ }^{289} \mathrm{Vgl}$. <https://ec.europa.eu/digital-single-market/en/digital-cultural-heritage> letzter Zugriff 17.08.2019.

${ }^{290}$ Vgl. Förderprogramm: H2020-Refelective-7-2014: Advanced 3D Modelling for Accessing and Understanding European Cultural Assets.

291 Vgl. Förderprogramm: H2020-DT-Transformations-12-2018-2020: Curation of digital assets and advanced digitization.

292 Vgl. Förderprogramm: H2020-Cult-Coop-8-2016: Virtual museums and social platforms on European digital heritage, memory, identity and cultural interaction.

${ }^{293} \mathrm{Vgl}$. <https://www.bmbf.de/foerderungen/bekanntmachung-2448.html> letzter Zugriff 17.08.2019.

${ }^{294} \mathrm{Vgl}$. Ebenda. Zudem sind textbasierte, zweidimensionale Objekte generell von der Förderung ausgeschlossen.

${ }^{295}$ Vgl. <https://www.deutsche.digitale-bibliothek.de> letzter Zugriff 21.08.2019.

296 Bayern, Bremen, Hamburg und Schleswig-Holstein. Vgl. Euler/Klimpel 2016.
} 
diesen Bundesländern hat ausschließlich Bayern mit der bereits erwähnten Plattform Bavarikon ein tatsächliches Konzept für die Digitalisierung und Verbreitung von materiellem Kulturgut erarbeitet. ${ }^{297}$

Bei der Betrachtung der Förderprogramme und geplanten Maßnahmen für die Umsetzung der Digitalisierungsstrategien fällt auf, dass das originale Objekt deutlich in den Hintergrund gerückt ist. Bei dem BMBF Förderprogramm eHeritage werden Maßnahmen zum Schutz des originalen Kulturerbes sogar explizit ausgeschlossen. Ellen Euler und Paul Klimpel schreiben in der Einführung zu den gemeinsamen Digitalisierungsstrategien der Bundesländer:

„Durch die Digitalisierung haben sich die Bedingungen grundlegend geändert, unter denen Kulturerbeeinrichtungen ihre Aufgabe erfüllen müssen. Denn die durch die Digitalisierung bewirkte leichtere Zugänglichkeit und Verbreitung geht mit der Gefahr einher, dass Kulturobjekte als Digitalisate aus ihrem Kontext herausgelöst werden. [...] Kulturelles Erbe muss im Netz präsent sein, damit es nicht an Relevanz einbüßt, und Kontexte müssen erhalten bleiben, damit Kulturerbe nicht seine Bedeutung verliert. ${ }^{298}$

Die Gefahr, Kulturerbe losgelöst von seinem Kontext über diese Plattformen zu verbreiten, scheint also erkannt, dennoch ist fraglich, wie genau dieser Gefahr entgegengetreten wird. Für Film- und Tonmaterial vermag es genügen, zusätzliche Informationen, Metadaten, in Form von erklärenden Texten oder Ähnlichem, dem Digitalisat beizufügen. Auch für die Kerninhalte historischer Schriften mag dies ausreichen, sofern man sich in der digitalen Vermittlung und Zugänglichkeit lediglich auf das geschriebene Wort beschränken möchte. Für eine Digitalisierungsstrategie materiellen Kulturerbes muss man sich jedoch zunächst bewusst werden, was das Kulturerbe als solches ausmacht. Brandi hat hierzu bereits deutliche Aussagen getroffen:

„Der materiellen Substanz des Kunstwerkes gebührt [...] ganz klar der Vorrang, weil das Bild durch die Materie Gestalt annimmt und diese Materie die Vermittlung des Bildes an die Zukunft sichert und damit seine Wahrnehmung durch das menschliche Bewusstsein. Wenn es darum geht, dass ein Kunstwerk als Kunstwerk erkannt wird, gebührt dem künstlerischen Aspekt absoluter Vorrang. Wenn das Erkennen allerdings darauf zielt, die Möglichkeit jener Entdeckung eines Kunstwerkes auch für die Zukunft zu erhalten, dann gewinnt die materielle Substanz dieses Kunstwerkes vorrangige Bedeutung. "299

Im Sinne der ausschließlichen Vermittlung der künstlerischen Aspekte eines Kulturerbes wäre eine virtuelle Präsentation nach diesen Prinzipien möglich. Hierbei wird der Betrachter an die Hand genommen; ihm wird das digitalisierte Objekt, bereits als Kulturerbe oder Kunstwerk bezeichnet, vorgeführt und ggf. wird über Metadaten eine Begründung, warum es sich um Kulturerbe handelt,

\footnotetext{
${ }^{297}$ Bayerisches Staatsministerium für Bildung und Kultus, Wissenschaft und Kunst 2016, S. $26 f$ und Rahrig 2017, S. 134.

${ }^{298}$ Euler/Klimpel 2016, S. $8 f$.

${ }^{299}$ Brandi 2006, S. $44 f$.
} 
mitgeliefert. Die eigenständige Erschließung des Objektes als Kunstwerk oder Kulturerbe bleibt dem Betrachter auf diesem Wege jedoch verwehrt, da die materielle Substanz fehlt.

Die materielle Substanz wird auf der einen Seite von dem Material oder der Komposition verschiedener Materialien, aus denen das Kulturerbe unmittelbar erstellt ist, gebildet. Hierzu zählen auch die Auswirkungen verändernder Prozesse aus der Objektgeschichte, wie die Bildung einer Patina, oder historisch begründete Ergänzungen und Reduktionen. Auf der anderen Seite zählen zu der materiellen Substanz eines Kulturerbes aber auch äußere Faktoren, wie es Brandi am Beispiel des Athener Parthenons darlegt:

„[...] zur Materie des Parthenons gehören in nicht geringerem Maße als der pentilische Marmor auch die Atmosphäre und das Licht dieses Ortes. Deswegen kann man das Entfernen eines Kunstwerkes von seinem ursprünglichen Ort einzig und allein damit rechtfertigen, dass dies für seine Konservierung unabdingbar ist. ${ }^{\text {300 }}$

Hiermit geht Brandi einen deutlichen Schritt weiter. Er hebt das Kulturgut über seine unmittelbar greifbare Existenz als materielles Objekt hinaus auf eine Metaebene, in der auch die umgebenden Faktoren zum Kulturgut zählen. Treffender als die Definition des Kulturguts über die Materie ist daher der Ausdruck der Authentizität eines Kulturguts. Laut David Scott beruht sie auf den drei Säulen ,Material', ,Geschichte' und ,Konzept' des Kulturerbes, welche bei allen Handlungen und Maßnahmen mit dem Kulturgut gleichermaßen berücksichtigt werden müssen. ${ }^{301}$ Janis formuliert das Konzept der Authentizität deutlich konkreter:

„Das Authentizitätskonzept variiert in Abhängigkeit von den jeweils kulturellen und zivilisatorischen Eigenheiten. Es umfaßt sowohl das Material und die Struktur, die Spuren der Herstellung, die Merkmale der individuellen Geschichte des Restaurierungsgegenstandes als auch die historische, kunsthistorische, ästhetische Bedeutung sowie die künstlerische ldee, die Funktion, den Standort und die Umgebung. ${ }^{\text {"302 }}$

Unter diesen Aspekten ist es ausgeschlossen, dass ein Digitalisat jemals ein Kulturgut authentisch repräsentieren kann. Es kann vielmehr lediglich eine Erinnerung an das Kulturerbe zum Zeitpunkt seiner Dokumentation, mehr oder weniger gut, wiedergeben. Leider wird diese Problematik in den Konzepten zu den Digitalisierungsstrategien derzeit nicht thematisiert. Es stellt sich die Frage nach dem aktuellen Mehrwert von Datenbanken wie Bavarikon ${ }^{303}$, der Deutschen Digitalen Bibliothek oder Europeana $^{304}$ für den Erhalt und die Erforschung von materiellem Kulturerbe. Sie dienen als reine Vermittler, um interessierte Nutzer auf die Existenz der jeweiligen Kulturgüter aufmerksam zu machen

\footnotetext{
${ }^{300}$ Brandi 2006, S. 50.

${ }^{301}$ Vgl. Scott 2015, 303f.

302 Janis 2005, S. 187.

${ }^{303}<$ https://www.bavarikon.de> letzter Zugriff 18.08.2019.

$304<$ https://www.europeana.eu> letzter Zugriff 18.08.2019.
} 
und sie so vielleicht zu einer realen Erkundung des Originals zu ermutigen. Es lassen sich über diese Portale auch zusätzliche Informationen über das Objekt abrufen, um ggf. die vor Ort am Kulturgut präsentierten Informationen weiter zu vertiefen. In diesem Falle ist jedoch fraglich, warum tatsächliche Maßnahmen zum Erhalt des Originals in den Förderrichtlinien der Digitalisierungsstrategien ausgeschlossen werden. Es droht somit die Gefahr, dass das Original in seiner weitläufigen Wahrnehmung hinter dem Digitalisat zurückbleibt. Dieser Gefahr muss dringend entgegengewirkt werden. So sollten auch bei der Formulierung und Erarbeitung von Konzepten für Förderprogramme ethische Grundsätze, wie die oben formulierten Leitsätze der Kulturerbeforschung, eingehalten werden. ${ }^{305}$ Alle Beteiligten müssen sich der Tatsache bewusst sein und werden, dass ein Kulturerbe als solches zu respektieren, in seiner kulturellen Bedeutung wahrzunehmen und für kommende Generationen zu wahren und zu schützen ist. ${ }^{306}$

Ein Digitalisat oder eine reale Kopie - egal wie sie erstellt wurde - kann niemals das Original ersetzen! Dies zeigte zuletzt die hitzige Diskussion über die, ethisch höchst fraglichen, 3D-Kopien des Triumphbogens des Hadrianstores aus Palmyra in Syrien. Sie wurden 2016 vom Institute of Digital Archaeology (IDA) aus einer Vielzahl an Einzelfotos von Touristen mittels Photogrammetrie zunächst virtuell rekonstruiert, anschließend in verschiedenen Gesteinsarten gefräst und in verkleinerter Form neu geschaffen. Die Triumphbögen werden seit dem an verschiedenen Orten als Zeichen der Solidarität für die syrische Bevölkerung und gegen das Terrorregime des Islamischen Staates (IS) präsentiert. ${ }^{307}$ Roshni Khunti von der University of Cambridge äußert hierzu deutliche Kritik, da die Kopien ohne Rücksprache mit der syrischen Bevölkerung erstellt wurden, bei der Präsentation der Bögen lediglich der IS als Zerstörer der antiken Stätten Palmyras genannt wird und die vom AssadRegime initialisierten Bombardements auf Truppen des IS unmittelbar in Palmyra und der damit einhergehenden weiteren Zerstörung der Stätte unerwähnt bleiben. ${ }^{308}$ Weiter kritisiert Khunti, dass die größten Fürsprecher der Solidarität im Zuge der Präsentation der Triumphbögen aus Ländern kamen, die die Aufnahme syrischer Flüchtlinge grundlegend abgelehnt, oder auf eine verschwindend geringe Höchstzahl limitiert haben. ${ }^{309}$

In der Zwischenzeit dementiert Roger Michel, Leiter des IDA, diese Vorwürfe in einem offenen Brief auf der Startseite des IDA. Dennoch bleibt die genannte Intention Michels, nach der die Kopien des Triumphbogens ein würdiger Ersatz des Originals und eines der Schwerpunktgebiete des IDA die Wiedererschaffung durch Terror und Naturkatastrophen zerstörten Kulturerbes seien, höchst

\footnotetext{
${ }^{305} \mathrm{Vgl}$. Kapitel 2.4.Ethische Grundsätze der Kulturerbeforschung, S. $14 \mathrm{ff}$.

${ }^{306}$ Vgl. Grundsatz Nr. 1, Kapitel 2.4.Ethische Grundsätze der Kulturerbeforschung, S. $14 \mathrm{ff}$.

${ }^{307} \mathrm{Vgl}$. <http://digitalarchaeology.org.uk/history-of-the-arch> letzter Zugriff 25.08.2019.

${ }^{308}$ Khunti 2018, S. 3f.

${ }^{309}$ Ebenda, S.7; siehe auch: Vinken 2017, S. $15 \mathrm{ff}$ und Wulf-Rheidt 2017, S. 32ff.
} 
problematisch. $^{310}$ Die italienische not-for-profit Organisation Factum Foundation for Digital Technology in Conservation, welche unter anderem die Replik der Grabkammer Tutanchamuns vor Ort im Tal der Könige in Luxor realisierte, weist eindrücklich auf die enormen Abweichungen zwischen den neu geschaffenen Triumphbögen und dem Original hin. Neben der deutlichen Verkleinerung des Objektes und der Verwendung einer anderen Gesteinsart werden besonders die Abweichungen in der Form der Triumphbögen kritisiert. So sind die gezeigten Gesimse und Kapitelle deutlich vereinfacht dargestellt, einige Kapitelle fehlen sogar gänzlich. ${ }^{311}$ Dies zeigt ganz deutlich die Probleme und Gefahren, die bei der Digitalisierung von Kulturerbe drohen und dass ethische Grundsätze im Umgang mit dem Kulturerbe und seiner Digitalisierung notwendig sind. Ein Digitalisat oder eine andere Kopie kann und wird niemals das Original ersetzen können. Es wird niemals eine 100\% authentische Wiedergabe des Kulturguts leisten können, wie Brandi bereits anmerkte:

„Es reicht nicht aus zu wissen, wie das Werk aussah, bevor es Ruine wurde, auch wenn man sich dabei auf eine noch so umfassende und detaillierte Dokumentation stützen könnte. Die Rekonstruktion, die Wiederherstellung und Kopie können gar nicht Gegenstand des Themas Restaurierung sein, da sie über dieses hinausgehen und wieder zur Fragestellung zurückführen, ob die mechanische Reproduktion der Vorgänge, die zur Formulierung eines Kunstwerkes führten, überhaupt zulässig sein kann oder nicht. "“112

Verschiedene Stellen streben daher derzeit die Formulierung von Richtlinien für die digitale Dokumentation von Kulturgut an. Die beiden existierenden Chartas und Richtlinien zum Umgang mit computerbasiert erstellten Visualisierungen von Kulturerbe, die Charta von London ${ }^{313}$ und die Charta von Sevilla ${ }^{314}$, sind dabei, nach Auffassung des Verfassers, für den Umgang mit 3D-Daten, welche durch moderne Vermessungstechniken erstellt wurden, weitestgehend undienlich. Trotz der sehr weit gefassten Formulierung, dass sie für alle computer-gestützt erstellten Darstellungen von Kulturgut gültig seien, ${ }^{315}$ können sie aufgrund der Formulierungen, Grundsätze und Zielsetzungen ausschließlich für frei am Computer erstellte Visualisierungen und Rekonstruktionen verwendet werden, denen keine Vermessungsdaten zugrunde liegen oder für die diese Daten nur eine deutlich abstrahierte Grundlage bildeten. An keiner Stelle wird in den Chartas zwischen Dokumentationsmethoden und interpretierenden, computergestützten Visualisierungen differenziert. Bei den in dieser Arbeit vorgestellten Methoden konnte jedoch klar herausgestellt werden, dass es sich um hochwertige Vermessungs- und Untersuchungstechniken handelt, die - sofern korrekt angewendet reproduzierbare und eindeutige Messergebnisse liefern. Es bedarf daher anderer Richtlinien oder der

\footnotetext{
$310<$ http://digitalarchaeology.org.uk> letzter Zugriff 22.08.2019.

${ }^{311}$ Vgl. Factum Foundation 2016, sowie Vinken 2017, S. 15ff und Wulf-Rheidt 2017, S. $32 \mathrm{ff}$.

312 Brandi 2006, S. 69.

313 London Charter 2009.

${ }^{314}$ Seville Charter 2011.

315 London Charter 2009, S. 5 und S. 13.
} 
Überarbeitung bestehender Richtlinien zur Dokumentation von Kulturerbe, damit diese der voranschreitenden technischen Entwicklung und Digitalisierung angepasst werden. Diese Richtlinien und Vorgaben für eine wissenschaftlich korrekte und denkmalgerechte Anwendung der Mess- und Dokumentationstechniken sollten von anerkannten Institutionen vertreten werden. In absehbarer Zeit wird es hierzu die notwendigen Expertentreffen mit Beteiligten von ICOMOS, CIPA Heritage Documentation ${ }^{316}$ und vergleichbarer Institutionen geben, sodass die neuen Technologien künftig als Werkzeug für den Erhalt des Kulturerbes und nicht zum reinen Selbstzweck oder der ausschließlichen medialen Präsentation genutzt werden können. ${ }^{317}$ Die Technologien müssen ergänzend und nicht ersetzend zu den etablierten Techniken eingesetzt werden, wie es Ashley-Smith bereits anmahnte:

"There have been numerous developments in methods to measure and control environments and ways to protect objects on display and transit. [...] New technologies offer new opportunities for 'doing nothing' directly to an object. Three-dimensional modelling and virtual restoration techniques mean that the fragile object need never be touched. Techniques such as $3 D$ printing, computer numerical control (CNC) for cutting and shaping, the use of lasers to clean surfaces and to monitor the cleaning process, all reduce the need for intervention involving the direct use of hands, and hence reduce the requirement to develop hand skills. [...] The new technologies are not universally applicable or appropriate, and more importantly, are not universally available. Therefore traditional approaches will continue to be necessary [...]." ${ }^{\prime 318}$

Mit der hier vorliegenden Arbeit konnte eindrücklich aufgezeigt werden, dass bildgebende zerstörungsfreie Prüfmethoden wertvolle, zusätzliche Werkzeuge für den Erhalt und vor allem die weiterführende Erforschung von Kulturerbe darstellen. Unter Beachtung der aufgeführten ethischen Grundsätze droht kein Missbrauch der Technik: vielmehr lassen sich Kulturgüter mit den vorgestellten Techniken zerstörungsfrei dokumentieren und Forschungsansätze, wie etwa zu in Serie produziertem Kulturgut, die bisher teilweise stark spekulativ waren, deutlich herausarbeiten und umsetzen. Mit der Wahl der richtigen Technik und einem möglichst ergänzenden Einsatz ${ }^{319}$ dieser ist es möglich, in verhältnismäßig kurzer Zeit komplexe Objekte, wie den heiligen Zahntempel in Kandy, umfassend zu dokumentieren und die Grundlage für denkmalgerechte CAD-Pläne auf der Basis von 3D-Punktwolken

\footnotetext{
${ }^{316}$ CIPA Heritage Documentation ist eines der Scientific Committees von ICOMOS und wurde 1968 gemeinsam mit der International Society for Photogrammetry and Remote Sensing (ISPRS) gegründet, mit dem Ziel, einen Beitrag zum Technologietransfer zwischen Vermessungstechnik und Denkmalpflege zuliefern. Vgl. < https://www.cipaheritagedocumentation.org/about/whatiscipa/ > letzter Zugriff 09.09.2019.

317 Vorbereitend fand hierzu auf der 27th International CIPA Conference in Avila, Spanien, am 04.09.2019 ein Ethics Panel for Cultural Heritage unter der Leitung von Prof. Mario Santan Quintero (ICOMOS) mit Vertretern von ICOMOS, CIPA, der Columbia University und Vertretern von not-for-profit Organisationen statt. Vgl. darüber hinaus: Santana Quintero et al. 2019; Manžuch 2017; sowie die Bestrebungen der HAWK, Hildesheim und dem Hornemann Institut im Rahmen der 2020 angesetzten Tagung "Das Fragment im digitalen Zeitalter Chancen und Risiken neuer Techniken in der Restaurierung" <https://www.hornemanninstitut.de/german/call for papers tagung fragmente.php> letzter Zugriff 22.08.2019.

${ }^{318}$ Ashley-Smith 2018, S. 7.

${ }^{319}$ Vgl. Remondino 2013, S. 121.
} 
zu erstellen, welche sowohl für die Bestandserfassung der Denkmalpflege wie auch der Restaurierung und Konservierung genutzt werden können. ${ }^{320}$ Ferner können die Daten, überführt in ein fotorealistisches 3D-Modell, als Grundlage für kunstwissenschaftliche Untersuchungen zur Entstehungs- und Nutzungsgeschichte verwendet werden, wie es am Bamberger Kaisersaal aufgezeigt wurde. An diesem Praxisbeispiel konnte zudem gezeigt werden, dass durch die gezielte Zusammenarbeit von Fotograf*innen und Vermesser*innen ein deutlicher Mehrwert in den erzielten Daten geliefert werden kann und dabei zudem Ressourcen durch das Einsparen redundanter Arbeitsprozesse mehrerer Akteur*innen eingespart werden können. ${ }^{321}$ Die Möglichkeit der mathematischen Berechnung und Visualisierung von Unterschieden zwischen 3D-Modellen stellt ein besonders vielseitig nutzbares Werkzeug in der Kulturerbeforschung und besonders für die Präventive Konservierung dar, das bisher weitestgehend unterschätzt und ungenutzt war. Es bietet gleichermaßen die Grundlage, um Aussagen zu Herstellungstechniken von in Serie produzierten Kulturgütern zu treffen, wie es anhand der Bambino Ebreo von Medardo Rosso eindrücklich gezeigt werden konnte. ${ }^{322}$ Ferner können sie der Qualitätskontrolle von restauratorischen Maßnahmen ${ }^{323}$ und dem Erfassen voranschreitender Schadensprozesse, die auf ein Kulturerbe einwirken, dienen. ${ }^{324}$ Durch die so gesammelten Daten und daran abgeleitetem Wissen um aktive und inaktive Schadensprozesse kann ein deutlicher Beitrag zur Präventiven Konservierung von Kulturgütern geleistet werden, in dem gezielt auf der Grundlage der erhobenen Daten die Notwendigkeit von Maßnahmen zum Erhalt des Objektes erkannt, geplant und eingeleitet werden können. Bei der abwägenden, bewussten Entscheidung für die richtige Technik lassen sich dabei auch komplexe Materialien und Oberflächen umfassend erfassen. Wie jedoch auch gezeigt werden konnte, stellen gewisse Materialien, wie etwa Glas oder anderer spiegelnde und transluzente Materialien, ein Problem bei der Erfassung ihrer Oberflächen dar. ${ }^{325}$

Besondere Stärken der vorgestellten Techniken liegen, wie am Beispiel des Opto-Technical Monitorings eindrücklich gezeigt werden konnte, in dem gezielten und kombinierten Einsatz, dem stets eine klare Fragestellung vorangestellt sein muss. ${ }^{326}$ Die vorgestellten Prozesse zur Auswertung der Daten lassen sich dabei frei skalieren, sodass die Berechnung von Unterschieden in den 3D-Modellen auch problemlos auf der Basis von TLS-Daten für das Monitoring der Verformung eines Gebäudes

\footnotetext{
${ }^{320}$ Kapitel 4.1. Der Zahntempel - Kulturerbeforschung und Wissenstransfer, S. 44ff.

${ }^{321}$ Kapitel 4.2. Der Bamberger Kaisersaal - Neue Möglichkeiten für eine kunsthistorische Analyse historischer Prunkräume, S. 60ff.

322 Kapitel 5.1. 3D-Vergleiche für kunstwissenschaftliche Serienanalysen, S. 83ff.

${ }^{323}$ Kapitel 5.2. 3D-Vergleiche für die Oberflächeninspektion und Qualitätskontrolle im laufenden Restaurierungsprozess, S. $107 \mathrm{ff}$.

${ }^{324}$ Kapitel 6. Opto-Technical Monitoring - 3D-Techniken und multispektrale Bildgebung, S. 127ff.

${ }^{325}$ Kapitel 5.2. 3D-Vergleiche für die Oberflächeninspektion und Qualitätskontrolle im laufenden Restaurierungsprozess, S. $107 \mathrm{ff}$.

${ }^{326}$ Kapitel 6. Opto-Technical Monitoring - 3D-Techniken und multispektrale Bildgebung, S. $127 \mathrm{ff}$.
} 
verwendet werden können und die Erstellung fotorealistischer Texturen natürlich auch gleichermaßen aus der Kombination von farbechten Fotos und hochauflösenden Detailscans, wie sie durch SLS erstellt werden, erfolgen kann.

In Anlehnung an die von Janis formulierten, obersten restaurierungsethischen Maxime, nach der alle Aktivitäten aller beteiligten Disziplinen „die Erhaltung des Objektes im ganzen Reichtum seiner Authentizität und Integrität “327 anstreben müssen, und im Hinblick der ethischen Grundsätze Sieben und $A c h t,{ }^{328}$ wurden zudem die theoretischen Grundlagen für eine langfristige Archivierung der erhobenen Daten und ihrer begleitenden Dokumentationen geschaffen. ${ }^{329}$ Denn nur so können die Maßnahmen und Forschungen langfristig und nachhaltig ihren Beitrag für die Erhaltung des Kulturerbes leisten.

Mit der vorliegenden Arbeit wurden deutliche Möglichkeiten für den Einsatz von berührungslosen und zerstörungsfreien, bildgebenden Messtechniken im Einsatzbereich der Kulturerbeforschung aufgezeigt. Der Mehrwert der verwendeten Techniken liegt dabei in der Analyse, der wissenschaftlichen Auswertung und der Observation kultureller Objekte. Die Verwendung von Technik allein kann dabei noch kein Kulturerbe erhalten und für kommende Generationen schützen. Bei dem gezielten Einsatz, unter einer vorab klar formulierten Fragestellung, können die abgeleitet Erkenntnisse und Rückschlüsse zum Zustand des Objektes jedoch einen aktiven Beitrag zu dessen Erhalt leisten. Es wurde in den Abhandlungen zudem gezeigt, dass die hochauflösende Dokumentation einer Oberfläche komplexe Arbeitsschritte bedarf, welche neben einem sicheren Umgang und ausreichend Erfahrung mit der Technik, auch umfassende Kenntnisse des Kulturguts und seiner Materie voraussetzen. Lediglich in Ausnahmefällen ist dieses Wissen gleichermaßen in einer einzelnen Akteur*in verkörpert, so dass für einen respektvollen, denkmalgerechten und zielorientierten Einsatz der vorgestellten Methoden die transdisziplinäre Zusammenarbeit zwingend erforderlich ist. Diese sollte dabei von den Akteur*innen ausgehen, die mit dem Schutz und der Bewahrung des jeweiligen Objektes betraut sind, da diese den Bedarf und die Probleme des Objektes kennen und nur so die notwendigen Forderungen und Fragestellungen an die Technik formulieren können. Dies setzt jedoch auch voraus, dass diese Akteur*innen ausreichend über die Möglichkeiten und Grenzen der Methoden informiert sind, wozu diese Arbeit (hoffentlich) beitragen konnte.

\footnotetext{
327 Janis 2005, $184 f$.

${ }^{328}$ Kapitel 2.4. Ethische Grundsätze der Kulturerbeforschung, S. $14 \mathrm{ff}$.

${ }^{329}$ Kapitel 7. Dokumentation und Archivierung, S. $145 \mathrm{ff}$.
} 


\section{Abbildungsverzeichnis}

\section{Rahmentext}

Abb.01-04: Max Rahrig, 2019.

Abb. 05: Anna Luib, 2016.

Abb.06-12: Max Rahrig, 2019.

Abb. 13: Eva Basse / Max Rahrig, 2019 inspiriert durch Verhoeven 2016, S. 169, Figure 4.21.

Abb. 14: Max Rahrig, 2019.

Abb. 15: Max Rahrig, 2018, identisch mit Figure 4 in Publikation 6.

Abb. 16: Max Rahrig, 2019.

Publikation 1: Sri Dalada Maligawa - 3D-Scanning and Documentation of the Temple of the Sacred Tooth Relic at Kandy, Sri Lanka (Rahrig/Luib 2017)

Fig. 1: Ajantha Ratnayake, Infosurv Lanka Ltd., 2015.

Fig. 2: Max Rahrig, 2014.

Fig. 3: Dieter Nitsche, Format4plus GmbH, 2015.

Fig. 4: Max Rahrig, 2016.

Fig. 5: Sören Siebe, Format4plus GmbH, 2015

Fig. 6: Max Rahrig, 2016.

Fig. 7-8: Anna Luib / Max Rahrig, 2016.

Fig. 9: Max Rahrig, 2017.

Publikation 2: Praxistaugliche Digitalisierung barocker Prunkräume - hochauflösende 3DDokumentation des Kaisersaals der Neuen Residenz in Bamberg (Rahrig 2019b)

Abb. 01: Bildarchiv Foto Marburg/BSV/Thomas Scheidt, Christian Stein (CbDD), 2016.

Abb. 02: Max Rahrig, 2018.

Abb. 03-04: Victoria Spicale, 2016.

Abb. 05-15: Max Rahrig, 2018.

Publikation 3: Rethinking Uniformity: Analysis of Rosso's Serial Forms of the Bambino ebreo through

Digital Surface Comparison (Rahrig/Street 2019)

Figure 13.01: Max Rahrig, 2019.

Figure 13.02-13.06: Ronald Street, 2019.

Figure 13.07-13.16: Max Rahrig, 2019.

Publikation 4: 3D Inspection of the Restoration and Conservation of Stained Glass Windows using High Resolution Structured Light Scanning (Rahrig/Torge 2019)

Figure 1: Sławomir Oleszczuk, 2017-2019.

Figure 2-12: Max Rahrig, 2019. 
Publikation 5: Opto-Technical Monitoring - A Standardized Methodology to Assess the Treatment of Historical Stone Surfaces (Rahrig/Drewello/Lazzeri 2018)

Figure 1: David Höpfner, 2016.

Figure 2: Max Rahrig, 2016.

Figure 3: Max Rahrig, Anna Luib, Christof Altmann, Leander Pallas, Katrin Vill, 2017.

Figure 4-5: Max Rahrig, 2017/2018.

Figure 6: David Höpfner / Max Rahrig, 2016/2017.

Figure 7-8: David Höpfner, 2016.

Figure 9: Max Rahrig, 2018.

Figure 11: Max Rahrig, Anna Luib, Christof Altmann, Leander Pallas, Katrin Vill, 2017.

Figure 12-13: David Höpfner, 2016/2017 mit Ergänzungen Max Rahrig.

Publikation 6: Wohin mit all den Scans? Über die dauerhafte Archivierung von 3D-Daten bedeutender Kulturgüter am Beispiel des Bamberger Kaisergrabs (Rahrig 2017)

Abb. 1-6 Max Rahrig 


\section{Literaturverzeichnis}

\section{Addison 2008:}

Addison, A.: „The Vanishing Virtual. Safeguarding heritage's endangered digital record.” In: Kalay, Y. / Kvan, T. / Affleck, J. (Hrsg.): New Heritage. New media and cultural heritage, London, New York, 2008, S. 27-39.

\section{AICCM 2002:}

Australian Institute for Conservation of Cultural Material: AICCM - CODE OF ETHICS AND CODE OF PRACTICE, 2002, <https://aiccm.org.au/sites/default/files/docs/AICCMBusinessDocs/CODE\%200F\%2 OETHICS\%20AND\%20CODE\%20OF\%20PRACTICE\%20Australian\%20Institute\%20for\%20Conservation\% 20of\%20Cultural\%20Material.pdf> letzter Zugriff 16.07.2019.

\section{Akasheh et al. 2010:}

Akasheh, T. S. / Lerma, J. L. / Cabrelles, M. / Haddad, N.: „The multispectral and 3D study of the Obelisk Tomb in Petra, Jordan." In: loannides, M. / Fellner, D. / Georgopoulos, A. / Hadjimitsis, D. (Hrsg): 3rd International Conference dedicated on Digital Heritage. Short Papers, Limassol, Cyprus, 2010, S. 3540.

\section{Akce et al. 2007:}

Akce, D. / Remondino, F. / Novák, D. / Hanusch, T. / Schrotter, G. / Gruen, A.: „Performance Evaluation of a coded structured light system for cultural heritage applications." In: Proc. SPIE 6491, Videometrics IX, 64910V, S. 1-12, Doi: http://doi.org/10.1117/12.705578.

\section{Al-kheder et al. 2009:}

Al-kheder, S. / Al-shawabkeh, Y. / Haala, N.: „Developing a documentation system for desert palaces in Jordan using 3D laser scanning and digital photgrammetry." In: Journal of Archaeological Sciences, Vol. 36, Elsevir, 2009, S. 537-546, Doi: https://doi.org/10.1016/j.jas.2008.10.009.

\section{Ashley-Smith 1982:}

Ashley-Smith, J.: „The ethics of conservation.” In: The Conservator, 6, 1982, S. 1-5.

\section{Ashley-Smith 1994:}

Ashley-Smith, J.: „A consistent approach to a mixed collection.” In: Oddey, A. (Hrsg.): Restoration: Is it Acceptable?, British Museum Occasional Paper No 99, London, 1994.

\section{Ashley-Smith 2009:}

Ashley-Smith, J.: „Chapter 2: The Basis of Conservation Ethics.” In: Richmond, A. / Bracker, A. (Hrsg.). Conservation - Principles, Dilemmas and Uncomfortable Truths, Oxford, Burlington, Elsevir/Butterworth-Heinemann, 2009, S. 6-24.

\section{Ashley-Smith 2017:}

Ashley-Smith, J.: „A role for bespoken codes of ethics." In: ICOM-CC (Hrsg.): $18^{\text {th }}$ Triennial Conference, Theory and history of conservation, Copenhagen, 2017, <https://www.icom-cc-publicationsonline.org/PublicationDetail.aspx?cid=a5101256-3816-4ff6-96b5-2a71c3eecc9e> letzter Zugriff 21.08.2019.

\section{Ashley-Smith 2018:}

Ashley-Smith, J.: „The ethics of doing nothing." In: Journal of the Institute of Conservation, 41, S. 6-15. 


\section{Bayerisches Staatsministerium für Bildung und Kultus, Wissenschaft und Kunst 2016:}

Bayerisches Staatsministerium für Bildung und Kultus, Wissenschaft und Kunst: „KulturgutDigitalisierungsaktivitäten im Land Bayern." In: Euler, E. / Klimpel, P. (Hrsg.): Föderale Vielfalt - Globale Vernetzung Strategien der Bundesländer für das kulturelle Erbe in der digitalen Welt, Berlin, 2016, S. 26-34, Doi: https://dx.doi.org/10.15460/ddb.2.168.

\section{BDA 2015:}

Bundesdenkmalamt (BDA) Hrsg.: Standards der Baudenkmalpflege, 2., korr. Auflage, Wien, 2015.

\section{Bellendorf 2007:}

Bellendorf, P.: Metallene Grabplatten aus Franken und Thüringen aus dem 15. bis 18. Jahrhundert eine interdisziplinäre Studie zum Denkmalbestand und seiner Gefährdung durch Umwelteinflüsse, Bamberg, University of Bamberg Press, 2007, <https://opus4.kobv.de/opus4bamberg/frontdoor/index/index/year/2008/docld/125> letzter Zugriff 23.08.2019.

\section{Bellendorf 2009:}

Bellendorf, P.: „3D-(laser)Scanning zur Vermessung von Kunst- und Kulturgut.“ In: Wiedemann, G. / Klotzbach, U. / Bauer-Bornemann, U. (Hrsg.): Laseranwendung in Restaurierung und Denkmalpflege: Grundlagen - Chancen - Perspektiven, Osnabrück, 2009, S. 197-204.

\section{Bellendorf 2011}

Bellendorf, P.: „Hochaufgelöste 3D-Dokumentation mittelalterlicher Oberflächen.“ In: Bennewitz, I. / Schindler, A. (Hrsg.): Farbe im Mittelalter. Materialität-Medialität-Semantik, Band I, Berlin, 2011, S. 95-102.

\section{Benjamin 1935:}

Benjamin, W.: "The Work of Art in the Age of Mechanical Reproduction." 1935. In: Benjamin, Walter, edited by Arendt, Hannah, translated by Zohn, Harry: Illuminations, New York, Schoken Books, 1969, S. 217-251.

\section{Beraldin et al. 2002:}

Beraldin, J.-A. / Picard, M. / El-Hakim, S. F. / Godin, G. / Valzano, V. / Bandiera, A.: „Virtualizing a Byzantine Crypt by Combining High-resolution Textures with Laser Scanner 3D Data." In: Proceedings of the 8th International Conference on Virtual Systems and Multimedia, 2002, S. 3-14.

\section{Bohnagen 1914:}

Bohnagen, A.: Der Stukkateur und Gipser, Leipzig (1914), Reprint München, Callway, 1987.

\section{Brandi 1956:}

Brandi, C.: "Cosa debba intendersi per restauro preventive." In: Bollettino del Istituto Centrale del Restauro, 1956, 27/28, S. 87-92.

\section{Brandi 2006:}

Brandi, C.: „Theorie der Restaurierung“, in Deutsch übersetzt von Schädler-Saub, U. und Jakobs, D.. In: Schädler-Saub, U. / Jakobs, D. (Hrsg.): Cesare Brandi, Theorie der Restaurierung, ICOMOS (Hrsg), Hefte des Deutchen Nationalkomitees XLI, München, 2006, S. 41-150. 


\section{Brepohl 2013:}

Brepohl, E.: Theophilus Presbyter und das mittelalterliche Kunsthandwerk, Böhlau Verlag Cologne/ Weimar/Vienna, 2013.

\section{BSV 2018:}

Bayerische Verwaltung der staatlichen Schlösser, Gärten und Seen (BSV) / Janis, K. / Holl, K.: Wissenschaftliche Begleitung einer Maßnahme zur Präventiven Konservierung in Schloss Linderhof, Abschlussbericht des von der Deutschenbundesstiftung Umwelt (DBU) unter dem Aktenzeichen 31017 geförderten Forschungsprojektes, München, 2018, <https://www.dbu.de/OPAC/ab/DBUAbschlussbericht-AZ-31017.pdf> letzter Zugriff 07.08.2019.

\section{Burmester 2004:}

Burmester, A.: „Was ist Präventive Konservierung? Eine Einführung.“ In: Krah und Grote (Hrsg.), Grundlagen der Meßtechnik in der Präventiven Konservierung, Tagungsband 2007 zu der Veranstaltung vom 30.09. - 01.10.2004, S. 8-11. Quelle als Druckversion nicht zu finden, jedoch als PDF unter <http://www.doernerinstitut.de/downloads/burmester Was ist PK.pdf> daher abweichende Seitenzahlen zur Originalquelle, letzter Zugriff 21.07.2019.

\section{Burmester 2005:}

Burmester, A.: „Es sind also alle die Gefahren: Vom Museumsbau, Feuer Luft und Staub.“ In: Fachhochschule Erfurt, Fachbereich Konservierung und Restaurierung / Germanisches Nationalmuseum Nürnberg, Institut für Kunsttechnik und Konservierung (Hrsg.): Veröffentlichung zur Tagung: Schadstoffvermeidung im Museum, 14.03.2005 bis 15.03.2005, Osnabrück, 2005, S. 1-13, <https://www.hornemann-

institut.de/german/epubl txt/Schadstoffvermeidung 001 Burmester.pdf> letzter Zugriff 21.07.2019.

\section{Cabrelles et al. 2009:}

Cabrelles, M. / Galcerá, S. / Lerma, J.L. / Akasheh, T. / Haddad, N.: „Integration of 3D laser scanning, photogrammetry and thermography to record architectural monuments." In: Proceedings of CIPA Symposium 22, Kyoto, 11-15 October, Japan, 2009, S. 1-6, <https://www.cipaheritagedocumentation.org/wp-content/uploads/2018/12/Cabrelles-e.a.Integration-of-3D-Laser-Scanning-Photogrammetry-and-Thermography-to-Record-ArchaeologicalMonuments.pdf> letzter Zugriff 23.09.2019.

\section{Cantor/Brandon 2012:}

Cantor, D. / Brandon J.: WebGL Beginner's Guide, Packt Publishing, Birmingham, 2012.

\section{Caple 2000:}

Caple, C.: Conservation Skills - Judgement, method and decision making, Routledge, London/New York, 2000.

\section{Caple 2009:}

Caple, C.: „Chapter 3: The Aims of conservation.” In: Richmond, A. / Bracker, A. (Hrsg.): Conservation Principles, Dilemmas and Uncomfortable Truths, Oxford, Burlington, Elsevir/Butterworth-Heinemann, 2009, S. 25-31.

\section{Ceynowa/Kellner 2014:}

Ceynowa, K. / Kellner, S.: „Das bayerische Kulturportal bavarikon - digital, vernetzt, spartenübergreifend." In: Bibliotheksmagazin, H. 1, 2014, S. 8-14. 


\section{Ceynowa/Kellner 2015:}

Ceynowa, K. / Kellner, S.: „Das bayerische Kulturportal bavarikon - digital, vernetzt, spartenübergreifend." In: Euler, E. / Hagedorn-Saupe, M. / Maier, G. / Schweibenz, W. / Sieglerschmidt, J. (Hrsg.): Handbuch Kulturportale, Berlin / Boston 2015, S. 292-300.

\section{Ceynowa/Sepp 2016:}

Ceynowa, K. / Sepp, F.: "Das Landesportal bavarikon in kulturpolitischer Perspektive." In: Bibliotheksmagazin, H. 2, 2016, S. 13-16.

\section{Ceynowa et al. 2016:}

Ceynowa, K. / Kellner, S. / Sepp, F.: „Bavarikon - Eine digitale Plattform auch für Museen. “ In: Museum Heute, H. 48, 2015, S. 52-56

\section{Chen et al. 2007:}

Chen, T. / Lensch, H. P. A. / Fuchs, C. / Seidel, H.-P.: „Polarization and Phase-Shifting for 3D Scanning of Translucent Objects." In: Proceedings of IEEE Computer Society Conference on Computer Vision and Pattern Recognition (CVPR), Minneapolis, 2007, S. 1-8, Doi: https://doi.org/10.1109/CVPR.2007.383209.

\section{Cignoni et al. 2008:}

Cignoni, P. / Callieri, M. / Corsini, M. / Dellepiane, M. / Ganovelli, F. / Ranzuglia, G.: „MeshLab: an OpenSource Mesh Processing Tool." In: Sixth Eurographics Italian Chapter Conference, S. 129-136, 2008.

\section{Colson 2021:}

Colson, A.: "Monitoring of large scale cultural Heritage objects using new technologies," Dissertationsvorhaben Universität Bamberg, 2021, in Vorbereitung.

\section{Coningham/Lewer 1999:}

Coningham, R. / Lewer, N.: „Paradise Lost: The bombing of the Temple of the Tooth - a UNESCO World Heritage site in Sri Lanka." In: Antiquity, 73, 1999, S. 857-866, Doi: https://doi.org/10.1017/S0003598X00065595.

\section{Cooper/Hecker 2004:}

Cooper, H. / Hecker, S. (Hrsg.): Medardo Rosso Second Impressions, London, Cambridge, Yale University Press 2004.

\section{Cosentino 2014:}

Cosentino, A.: „Identification of pigments by multispectral imaging; a flowchart method." In: Heritage Science, 2014 2:8, Doi: https://doi.org/10.1186/2050-7445-2-8.

\section{Cosentino 2015:}

Cosentino, A.: „Practical notes on ultraviolet technical photography for art examination”. In: Conservar Património 21, 2015, S. 53-62, Doi: https://doi.org/10.14568/cp2015006.

\section{D'Andrea 2016:}

D’Andrea, A.: "Providing 3D Content to Europeana." In: Campana, S. / Scopigno, R. / Carpentiero, G. / Cirillo, M. (Hrsg.): CAA2015. Keep the Revolution going. Proceedings of the 43rd Annual Conference on Computer Applications and Quantitative Methods in Archaeology, Oxford, 2016, S. 269-274. 


\section{De Roos 2004:}

De Roos, H.: „The Digital Sculpture Project Applying 3D Scanning Techniques for the Morphological Comparison of Sculptures." In: Computer and Information Science, Vol. 9, no. 2, Linköping, Linköping University Electronic Press, 2004, S. 1-84,

\section{De Silva 1985:}

De Silva, T. K. N. P.: Temple of the Tooth, Kandy. Architecture, Sculpture, Painting, Colombo, 1985.

\section{De Silva 1994:}

De Silva, T. K. N. P.: Kandy - A World Heritage City, Colombo, 1994.

\section{Dehio 1905:}

Dehio, G.: „Denkmalschutz und Denkmalpfelge im neunzenhten Jarhundert - Festrede an der KaiserWilhelms-Universität zu Straßburg, den 27. Januar 1905." In: Dehio, G.: Kunsthistorische Aufsätze, Oldenbourg Verlag, München, Berlin, 1914, S. 260-282, <https://archive.org/details/kunsthistorische 00dehiuoft> letzter Zugriff 16.07.2019.

\section{Dorell 1994}

Dorell, P.: „Ultra-Violet and Infra-Red Photography.“ In: Photography in Archaeology and Conservation, Cambridge Manuals in Archaeology, Second Edition, Cambridge University Press, 1994, S. 198-207, Doi: https://doi.org/10.1017/CBO9780511621932.013.

Díaz-Marín et al. 2016:

Díaz-Marín, M. D. C. / Aura Castro, E. / Sánchez Belenguer, C. / Vendrell Vidal, E.: "Cyclododecane as opacifier for digitalization of archaeological glass." In: Journal of Cultural Heritage, Vol. 17, 2016, S. 131-140, Doi. https://doi.org/10.1016/i.culher.2015.06.003.

\section{Diemer 2015:}

Diemer, D.: „Kaisertumba.“ In: Exner, M. (Hrsg.): Die Kunstdenkmäler von Bayern, Regierungsbezirk Oberfranken, IV, Die Kunstdenkmäler von Oberfranken, Stadt Bamberg, Domberg, 1. Das Domstift, Teil 2: Ausstattung, Kapitelsbauten, Domschatz, Bd. IV, Stadt Bamberg Bd. 2.1/2, 2015, S. 1224-1251.

\section{Drewello/Kleine et al. 2010:}

Drewello, R. / Kleine, M. / Bellendorf, P.: „Das mittelalterliche Mosesfenster in Straubing.“ In: Pilosi, L. / Shepard, M. B. / Strobl, S. (Hrsg.): The Art of Collaboration Stained-Glass Conservation in the Twentyfirst century, Harvey Miller Publishers, 2010, S.183-192.

\section{Drewello/Wetter/Rahrig et al. 2010:}

Drewello, R. / Wetter, N. / Rahrig, M. / Bellendorf, P.: ,3D-Dokumentation mittelalterlicher Glasmalerei mit der Methode der 3D-Weißlicht-Streifenprojektion." In: Bornschein, F. / Torge, M. / Sabel, M. / Feldmann, I. / Kohl, A. / Sterzing, N. / Hahn, O. / Drewello, R. / Wetter, N. / Rahrig, M. / Bellendorf, P. (Hrsg.): Konservierung mittelalterlicher Glasmalerei im Kontext spezieller materieller und umweltbedingter Gegebenheiten. Dom zu Erfurt St. Marien, Domkapitel, 2010, S. 142-154, https://doi.org/10.5165/hawk-hhg/epublication/43.

\section{Drewello 2011:}

Drewello, R: „Exkurs 3: Restaurierungswissenschaft und Denkmalpflege.“ In: Hubel, A. (Hrsg.): Denkmalpflege - Geschichte, Themen, Aufgaben - Eine Einführung, Stuttgart, 2011, S. 274-309. 


\section{Drewello/Kleine 2016:}

Drewello, R. / Kleine, M. / Bellendorf, P.: „Das Mosesfenster in St. Jakob in Straubing im Schnittpunkt von Wissenschaft, Restaurierung und topografischer Dokumentation." In: Corpus Vitrearum Deutschland / Germanisches Nationalmuseum (Hrsg.): Originale Kaltmalerei auf historischen Glasmalereien, arthistoricum.net, Heidelberg, 2016, S. 73-80, Doi: https://doi.org/10.11588/arthistoricum.383.545.

\section{Drewello 2019:}

Drewello, R.: „Restaurierungswissenschaft.“ In: Arera-Rütenik, T. / Breitling, S. / Drewello, R. / Hess, M. / Vinken, G. (Hrsg.): Kompetenzzentrum Denkmalwissenschaften und Denkmaltechnologien 2016 2018, KDWT (Hrsg.): Berichte des KDWT Band 1, 2019, S. 83-85, Doi: http://dx.doi.org/10.20378/irbo$\underline{54686}$

\section{Dümler 2001:}

Dümler, C.: Die Neue Residenz in Bamberg - Bau- und Ausstattungsgeschichte der fürstbischöflichen Hofhaltung im Zeitalter der Renaissance und des Barock, Degener, Neustadt/Aisch, 2001.

\section{Dyer et al. 2013:}

Dyer, J. / Verri, G. / Cupitt, J.: Multispectral Imaging in Reflectance and Photo-induced Luminescence modes: A User Manual, Version 1.0, October 2013, part of the EC-Project CHARISMA (Cultural Heritage Advanced Research Infrastructures: Synergy for a Multidisciplinary Approach to Conservation/Restoration), <https://www.britishmuseum.org/pdf/charisma-multispectral-imagingmanual-2013.pdf> letzter Zugriff 06.08.2019.

\section{E.C.C.O. 2002:}

European Confederation of Conservator-Restorers' Organisations A.I.S.B.L. (E.C.C.O.): Professional Guidelines (I) The Profession, 2002, <http://www.eccoeu.org/fileadmin/user upload/ECCO professional guidelines I.pdf> letzter Zugriff 21.07.2019.

\section{E.C.C.O. 2003:}

European Confederation of Conservator-Restorers' Organisations A.I.S.B.L. (E.C.C.O.): Professional Guidelines (II) Code of Ethics, 2003, < $\underline{\text { http://www.ecco- }}$ eu.org/fileadmin/user upload/ECCO professional guidelines II.pdf> letzter Zugriff 21.07.2019.

\section{Eckstein 1999:}

Eckstein, G.: Empfehlungen für Baudokumentationen - Bauaufnahme - Bauuntersuchung, Stuttgart, 1999.

\section{El-Hakim et al. 2003:}

El-Hakim, S. / Beraldin, S. F. / Picard, J.-A. / Vettore, A.: „Effective 3D Modeling of Heritage Sites.” In: The 4th International Conference of 3D Imaging and Modeling, 2003, S. 302-309, Doi: https://doi.org/10.1109/IM.2003.1240263.

\section{Eren 2010:}

Eren, G.: 3D scanning of transparent objects. Université de Bourgogne, 2010DIJOS029, tel-00584061, <https://tel.archives-ouvertes.fr/tel-00584061> letzter Zugriff 14.072019. 


\section{Erichsen 2007:}

Erichsen, J.: „Die Kaiserwohnung der Bamberger Residenz - Zweckbestimmung und Bildprogramm.“ In: Erichsen, J. / Heinemann, K. / Janis, K.: KaiserRäume - KaiserTräume - Forschen und Restaurieren in der Bamberger Residenz, Hirmer, München, 2007, S. 34-53.

Erichsen et al. 2007:

Erichsen, J. / Heinemann, K. / Janis, K.: KaiserRäume - KaiserTräume - Forschen und Restaurieren in der Bamberger Residenz, Hirmer, München, 2007.

\section{Euler/Klimpel 2016:}

Euler, E. / Klimpel, P. (Hrsg.): Föderale Vielfalt - Globale Vernetzung Strategien der Bundesländer für das kulturelle Erbe in der digitalen Welt, Berlin, 2016, Doi: https://dx.doi.org/10.15460/ddb.2.168.

\section{Europeana 2009:}

Europeana: „Die digitale Bibliothek Europas, ist online.“ In: Zeitschrift für Bibliothekswesen und Bibliographie (ZfBB), Bd. 56, 2009, S. 44.

\section{Factum Foundation 2016:}

Factum Foundation: IDA Palmyra Arch Copy, 2016, <http://www.factumfoundation.org/pag/236/> letzter Zugriff 19.08.2019.

\section{Fangi et al. 2018:}

Fangi, G. / Pierdicca, R. / Sturari, M. / Malinverni, E. S.: „Improving Spherical Photogrammetry Using 360 Omni-Cameras: Use Cases And New Applications." In: Int. Arch. Photogramm. Remote Sens. Spatial Inf. Sci., XLII-2, 2018, S. 331-337, Doi: https://doi.org/10.5194/isprs-archives-XLII-2-331-2018.

\section{Floth/Breuer 2011:}

Floth, M. / Breuer, M.: „Optische 3D-Messtechniken für die berührungslose, detaillierte Erfassung von Objektoberflächen in Archäologie und Denkmalpflege." In: Heine, K. / Rheidt, K. / Henze, F. / Riedel, A. (Hrsg.): Von Handaufmass bis High Tech III, 3D in der historischen Bauforschung, Verlag Philipp von Zabern, Darmstadt/Mainz, 2011, S. 8-13.

\section{Fuhrmann 2014:}

Fuhrmann, C. / Santos, P. / Fellner, D.: „Cultlab3D: Ein mobiles 3D-Scanning Szenario für Museen und Galerien." In: Bienert, A. / Hemsley, J. / Santos, P: (Hrsg.): EVA Berlin 2014, Elektronische Medien \& Kunst, Kultur und Historie, Darmstadt/Berlin, 2014, S. 106-109.

\section{Fuhrmann 2015:}

Fuhrmann, C. / Santos, P. / Fellner, D.: „3D-Massendigitalisierung - ein Meilenstein für die museale Nutzung." In: Museumskunde, Bd. 80, H. 1, 2015, S. 58-61.

\section{Furht 2008:}

Furht, B.: Encyclopedia of Multimedia (2nd ed.), New York, Springer, 2008.

\section{Gnoizzi Barsanti et al. 2013:}

Gonizzi Barsanti, S. / Remondino, F. / Visintini, D.: „3D Surveying and Modeling of archaeological sites - some critical issues." In: ISPRS Ann. Photogramm. Remote Sens. Spatial Inf. Sci., II-5/W1, 2013, S. 145150, Doi: https://doi.org/10.5194/isprsannals-II-5-W1-145-2013. 


\section{Gnoizzi Barsanti/Guidi 2013:}

Gonizzi Barsanti, S. / Guidi, G.: „3D Digitization of Museum Content within the 3DICONS Project.” In: ISPRS Ann. Photogramm. Remote Sens. Spatial Inf. Sci., II-5/W1, 2013, S. 151-156, Doi: https://doi.org/10.5194/isprsannals-II-5-W1-151-2013.

\section{Grussenmeyer et al. 2016:}

Grussenmeyer, P. / Landes, T. / Doneus, M. / Lerma, L.L.: „Basics of Rang-Based Modelling Techniques in Cultural Heritage 3D Recording." In: Stylianidis, E. / Remondino, F. (Hrsg.): 3D Recording, Documentation and Management of Cultural Heritage, Whittles Publishing, Dunbeath, 2016, S. 305368.

\section{Gühring 2002:}

Gühring, J.: 3D-Erfassung und Objektrekonstruktion mittels Streifenprojektion, Dissertationsschrift an der Universität Stuttgart, zugleich Deutsche Geodätische Kommission (Hrsg.): Reihe C Heft Nr. 560, 2002,<https://d-nb.info/980546680/34> letzter Zugriff 06.08.2019.

\section{Guillemard 1992:}

Guillemard, D.: „Éditorial.” In: $3^{e}$ Colloque International de l'ARAAFU, Paris, 1992, S. 13-18.

\section{Hecker 2017:}

Hecker, S.: A Moment's Monument, Medardo Rosso and the International Origins of Modern Sculpture, Oakland, University of California Press, 2017.

\section{Hecker 2017:}

Hecker, S.: „The afterlife of sculptures: posthumous casts and the case of Medardo Rosso (18581928)." In: Journal of Art Historiography, 16/SH1, Glasgow, Institute for Art History, University of Glasgow, 2017, S. 1-18, <https://arthistoriography.files.wordpress.com/2017/06/hecker.pdf> letzter Zugriff 23.08.2019.

\section{Henderson 2011:}

Henderson, J.: Reflections on Decision-Making in Conservation, ICOM-CC Lisbon 2011, S. 1-8.

\section{Hexagon 2019:}

Hexagon Metrology GmbH: AICON StereoScan neo, Technische Daten, 2019, <https://www.hexagonmi.com/de-DE/products/white-light-scanner-systems/aicon-stereoscan-neo> letzter Zugriff 02.08.2019.

\section{Hirst et al. 2018:}

Hirst, C. S. / White, S. / Smith, S. E.: "Standardisation in 3D Geometric Morphometrics. Ethics, Ownership and Methodes." In: Archaeologies, Journal of the World Archaeological Congress, Vol. 14, No. 2, S. 272-298, Doi: https://doi.org/10.1007/s11759-018-9349-7.

\section{Historic England 2017:}

Historic England (Hrsg.): Photogrammetric Applications for Cultural Heritage. Guidance for Good Practice, Swindon, 2017, <https://historicengland.org.uk/imagesbooks/publications/photogrammetric-applications-for-cultural-heritage/> letzter Zugriff 06.08.2019. 


\section{Historic England 2018:}

Historic England (Hrsg.): 3D Laser Scanning for Heritage: Advice and Guidance on the Use of Laser Scanning in Archaeology and Architecture, Swindon, 2018, <https://historicengland.org.uk/imagesbooks/publications/3d-laser-scanning-heritage/> letzter Zugriff 06.08.2019.

\section{Horn 2016:}

Horn, F.: „Die 3D-Digitalisierung im Kulturportal bavarikon.“ In: Museum Heute, H. 50, 2016, S. 80-83.

\section{Hullin et al. 2008:}

Hullin, M.B. / Fuchs, M. / Ihrke, I. / Seidel, H.P. / Lensch, H.P.A.: „Fluorescent Immersion Range Scanning." In: ACM Transactions on Graphics, Vol. 27, Issue 3, Article 87, 2008, Doi: https://doi.org/10.1145/1360612.1360686.

\section{Hundemer 2015:}

Hundemer, M. im Interview mit Eberling, F. / Gleiss, J.: „Digitale Dokumentation. Gegen digitales Vergessen." In: Restauro, H. 8, 2015, S. 28-30.

\section{IBM 2015:}

Exhibition of the International Buddhist Museum (IBM) of Sri Dalada Maligawa, Hemamali Mawatha, Kandy, Sri Lanka, besucht Nov./Dez. 2015, <https://ibm.sridaladamaligawa.lk> letzter Zugriff 23.08.2019.

\section{ICCROM 2018a:}

ICCROM: Heritage Science, <https://www.iccrom.org/section/heritage-science> letzter Zugriff 10.07.2019.

\section{ICCROM 2018b:}

ICCROM: Preventive Conservation, <https://www.iccrom.org/section/preventive-conservation> letzter Zugriff 22.07.2019

\section{ICOM-CC 2008:}

ICOM-CC: Terminology to characterize the conservation of tangible cultural heritage, Resolution adopted by the ICOM-CC membership at the 15th Triennial Conference, New Delhi, 22-26 September 2008, <http://www.icom-cc.org/54/document/icom-cc-resolution-terminology-english/?id=744> letzter Zurgiff 22.07.2019.

\section{ICOM 2014:}

ICOM-Deutschland / Waentig, F. / Dropmann, M. / Konold, K. / Spiegel, E. / Wenzel, Chr. (Hrsg.): Präventive Konservierung - Ein Leitfaden, Beiträge zur Museologie, Band 5, 2014.

\section{ICOM 2017:}

International Council of Museums (ICOM): Code of Ethics for Museums, 2017, <https://icom.museum/wp-content/uploads/2018/07/ICOM-code-En-web.pdf> letzter Zugriff 21.08.2019.

\section{ICOMOS 1964:}

International Council on Monuments and Sites (ICOMOS) (Hrsg.): International Charter for the Conservation and Restauration of Monuments and Sites (The Venice Charter 1964), $<$ https://www.icomos.org/charters/venice e.pdf> letzter Zugriff 21.08.2019. 


\section{ICON 2014:}

Institute of Conservations (ICON): The Institute of Conservations's Code of Conduct, 2014, $<$ https://icon.org.uk/system/files/documents/icon code of conduct.pdf> letzter Zugriff 21.08.2019.

Ihrke et al. 2010:

Ihrke, I. / Kutulakos, K. N. / Lensch, H. P. A. / Magnor, M. / Heidrich, W.: „Transparent and Specular Object Reconstruction." In: Computer Graphics forum, Vol. 29, 8, 2010, S. 2400-2426, Doi: https://doi.org/10.1111/j.1467-8659.2010.01753.x.

\section{Janis 2005:}

Janis, K.: Restaurierungsethik im Kontext von Wissenschaft und Praxis; Forum Denkmal und Restaurierung Bd. 1; München, 2005.

\section{Khunti 2018:}

Khunti, R.: "The Problem with Printing Palmyra: Exploring the Ethics of Using 3D Printing Technology to Reconstruct Heritage." In: Studies in Digital Heritage, Vol. 2, Nr. 1, 2018, S. 1-12, Doi: https://doi.org/10.14434/sdh.v2i1.24590.

\section{Lackner 2017:}

Lackner, P.: Qualitativer Vergleich des 3D-LAserscannings mit dem ,Structure from Motion' - Verfahren. Unveröffentlichte Abschlussarbeit im Masterstudiengang Denkmalpflege/Heritage Conservation, Universität Bamberg, 2017.

\section{Lang/Lenz 2017:}

Lang, V. / Lenz, R.: „„,Einiges über die Farbe ..." Zur Wandmalereitechnik von Adolf Hölzel.“ In: Landesamt für Denkmalpflege Stuttgart (Hrsg.): Mit Religion kann man nicht malen. Adolf Hölzel in Ulm, Ulm, 2017, S. 74-97.

\section{Leica 2019:}

Leica Geosystems AG: Leica ScnaStation P30/P40, 2019, < https://leica-geosystems.com//media/files/leicageosystems/products/datasheets/scan/leica\%20scanstation\%20p30p40\%20ds\%20839696\%200119\%20en\%20heritage\%20lr.ashx?la=dede\&hash=6A090A88B0583CD386CF870624057BOF> letzter Zugriff 02.08.2019.

\section{Lerma et al. 2010:}

Lerma, J. L. / Navarro, S. / Cabrelles, M. / Villaverde, V.: „Terrestrial laser scanning and close range photogrammetry for 3D archaeological documentation: the Upper Palaeoloithic Cave of Parpalló as a case study." In: Journal of Archaeological Science, Vol. 37, Elsevir, 2010, S. 499-507, Doi: https://doi.org/10.1016/i.jas.2009.10.011.

\section{Lerma et al. 2011:}

Lerma, J. L. / Navarro, S. / Cabrelles, M. / Sguí, A. E. / Haddaq, N. / Akasheh, T.: „Integration of Laser Scanning and Imagery for Photrealsitic 3D Architectural Documentation." In: Wang, C.-C. (Hrsg.): Laser Scanning, Theory and Applications, 2011, S. 413-430, Doi: https://doi.org/10.5772/14534.

\section{Lie 2004:}

Lie, H.: „Technical Features in Rosso's Work.” In: Cooper, H. / Hecker, S. (Hrsg.): Medardo Rosso Second Impressions, London, Cambridge, Yale University Press, 2004, S. 69-93. 


\section{London Charter 2009:}

Denard, H. (Hrsg): The London Charter - For the Computer-based Visualisation of Cultural Heritage, $\begin{array}{llll}\text { Draft 2.1, } 7 . & \text { February }\end{array}$ <http://www.londoncharter.org/fileadmin/templates/main/docs/london charter 21 en.pdf> letzter Zugriff 22.08.2019.

\section{Luhmann 2018:}

Luhmann, T.: Nahbereichsphotogrammetrie: Grundlagen - Methoden - Beispiele, 4., neu bearbeitet und erweiterte Auflage, Berlin, 2018.

\section{Luib 2019a:}

Luib, A.: „Infrarot-Thermographie in der technischen Bauwerksanalyse: Engführung historischer und technischer Bauforschung." In: Arera-Rütenik, T. / Breitling, S. / Drewello, R. / Hess, M. / Vinken, G. (Hrsg.): Kompetenzzentrum Denkmalwissenschaften und Denkmaltechnologien 2016 - 2018, KDWT (Hrsg.): Berichte des KDWT Band 1, 2019, S. 74-77, Doi: http://dx.doi.org/10.20378/irbo-54686.

\section{Luib 2019b:}

Luib, A.: „Infrared Thermal Imaging as a Non-Destructive Investigation Method for Building Archaeological Purposes." In: Int. Arch. Photogramm. Remote Sens. Spatial Inf. Sci., XLII-2/W15, 2019, S. 695-702, Doi: https://doi.org/10.5194/isprs-archives-XLII-2-W15-695-2019.

\section{Kacyra 2009:}

Kacyra, B.: "CyArk 500 - 3D Documentation of 500 Important Cultural Heritage Sites." In: Fritsch, D. (Hrsg.): Photogrammetric Week '09, Heidelberg, 2009, S. 315-320.

\section{Manžuch 2017:}

Manžuch, Z.: „Ethical Issues In Digitization Of Cultural Heritage." In: Journal of Contemporary Archival Studies, Vol. 4, Issue 2, Article 4, 2017, S. 1-17, <http://elischolar.library.yale.edu/jcas/vol4/iss2/4> letzter Zugriff 19.08.2019.

\section{Menna et al. 2016:}

Menna, F. / Nocerino, E. / Remondino, F. / Dellepiane, M. / Callieri, M. / Scopigno, R.: „3D digitization of an heritage masterpiece - a critical analysis on quality assessment." In: Int. Arch. Photogramm. Remote Sens. Spatial Inf. Sci., XLI-B5, 2016, S. 675-683, Doi: https://doi.org/10.5194/isprsarchives-XLIB5-675-2016.

\section{Mériaudeau et al. 2012:}

Mériaudeau, F. / Rantoson, R. / Fofi, D. / Stolz, C.: „Review and comparison of non-conventional imaging systems for three-dimensional digitization of transparent objects." In: J. Electron. Imag., Vol. 21 (2), 021105, 2012, S. 1-6, Doi: https://doi.org/10.1117/1.JEl.21.2.021105.

\section{Merzenich 2005:}

Merzenich, Chr.: „Prävention in der Restauratorenausbildung.“ In: Fachhochschule Erfurt, Fachbereich Konservierung und Restaurierung / Germanisches Nationalmuseum Nürnberg, Institut für Kunsttechnik und Konservierung (Hrsg.): Veröffentlichung zur Tagung: Schadstoffvermeidung im Museum, 14.03.2005 bis 15.03.2005, Osnabrück, 2005, S. 1-11, <https://www.hornemanninstitut.de/german/epubl txt/Schadstoffvermeidung 004 Merzenich.pdf> letzter Zugriff 21.07.2019 


\section{Muñoz Viñas 2002:}

Muñoz Viñas S.: „Contemporary Theory of Conservation.” In: Studies in Conservation, Vol. 47: sup. 1, 2002, S. 25-34, Doi: https://doi.org/10.1179/sic.2002.47.Supplement-1.25.

Muñoz Viñas 2011:

Muñoz Viñas, S.: Contemporary Theory of Conservation, $2^{\text {nd }}$ edition, Routledge, New York, 2011.

\section{Murtiyoso/Grussenmeyer 2017:}

Murtiyoso, A. / Grussenmeyer, P.: "Documentation of Heritage Buildings using Close-Range UAV Images: Dense Matching Issues, Comparison and Case Studies." In: The Photogrammetric Record, 32(159), 2017, S. 206-229, Doi: http://doi.org/10.1111/phor.12197.

\section{Nestor-Handbuch 2010:}

Neuroth, H. / Oßwald, A. / Scheffel, R. / Strathmann, S. / Huth, K. (Hrsg.): Nestor-Handbuch. Eine kleine Enzyklopädie der digitalen Langzeitarchivierung. Version 2.3, 2010, <http://nestor.sub.unigoettingen.de/handbuch/> letzter Zugriff 23.08.2019.

\section{Newman/Jain 1995:}

Newman, T. S. / Jain, A. K.: „A system for 3D CAD-based inspection using range images.” In: Pattern Recognition, Vol. 28, no. 10, Elsevir, 1995, S. 1555-1574, Doi: https://10.1016/0031-3203(95)00028-X.

\section{Nocerino et al. 2018:}

Nocerino, E. / Rieke-Zapp, D. H. / Trinkl, E. / Rosenbauer, R /, Farella, E. M. / Morabito, D. / Remondino, F.: "Mapping VIS and UVL Imagery on 3D Geometry for Non-Invasive, Non-Contact Analysis of a Vase." In: Int. Arch. Photogramm. Remote Sens. Spatial Inf. Sci., XLII-2, 2018, S. 773-780, Doi: https://doi.org/10.5194/isprs-archives-XLII-2-773-2018.

Pfeuffer/Rahrig et al. 2018:

Pfeuffer, C. / Rahrig, M. / Drewello, R. / Snethlage, R.: „3D mapping as a tool for the planning of preservation measures on sculptures made of natural stone." In: Environmental Earth Sciences, Springer, Vol. 77:312, 2018, S. 1-12, Doi: https://doi.org/10.1007/s12665-018-7479-2.

\section{Polymetric 2017:}

ISRA VISION Polymetric GmbH: Quick Reference Guide - QTSculptor v 6.0., 11.12.2017 v1.1.

\section{Pullen 2004:}

Pullen, D.: „Gelatin Molds: Rosso's Open Secret.” In: Cooper, H. / Hecker, S. (Hrsg.): Medardo Rosso Second Impressions, London, Cambridge, Yale University Press, 2004, S. 96-102.

\section{Quatember et al. 2012:}

Quatember, U. / Thuswaldner, B. / Kalasek, R. / Breuckmann, B. / Bathow, Ch.: „The Virtual and Physical Reconstruction of the Octagon and Hadrian's Temple in Ephesus." In: Bock, H. G. / Jäger, W. / Winckler, M. J. (Hrsg.): Scientific Computing and Cultural Heritage. Contributions in Computional Humanities, Contributions in Mathematical and Computational Sciences 3, Heidelberg, 2012, S. 217-228. 


\section{Rahrig 2017:}

Rahrig, M.: „Wohin mit all den Scans? - Über die dauerhafte Archivierung von 3D-Daten bedeutender Kulturgüter am Beispiel des Bamberger Kaisergrabs. “ In: Franz, B. / Vinken, G. (Hrsg.): Das Digitale und die Denkmalpflege: Bestandserfassung - Denkmalvermittlung - Datenarchivierung - Rekonstruktion verlorener Objekte, Veröffentlichungen des Arbeitskreises Theorie und Lehre der Denkmalpflege e.V., Band 26, Heidelberg, 2017, S. 130-139, Doi: http://dx.doi.org/10.11588/arthistoricum.263.348.

\section{Rahrig/Luib 2017:}

Rahrig M. / Luib A.: "Sri Dalada Maligawa - 3D-Scanning and Documentation of the Temple of the Sacred Tooth Relic at Kandy, Sri Lanka." In: ISPRS Ann. Photogramm. Remote Sens. Spatial Inf. Sci., IV2/W2, 2017, S. 229-236, Doi: https://doi.org/10.5194/isprs-annals-IV-2-W2-229-2017.

\section{Rahrig et al. 2018:}

Rahrig, M. / Drewello, R. / Lazzeri, A.: „Opto-Technical Monitoring - A standardized methodology to assess the treatment of historical stone surfaces." In: Int. Arch. Photogramm. Remote Sens. Spatial Inf. Sci., XLII-2, 2018, S. 945-952, Doi: https://10.5194/isprs-archives-XLII-2-945-2018.

\section{Rahrig 2019a:}

Rahrig, M.: „Monitoring historischer Oberflächen: Verwendung von Shearographie und Structured Light Scanning." In: Arera-Rütenik, T. / Breitling, S. / Drewello, R. / Hess, M. / Vinken, G. (Hrsg.): Kompetenzzentrum Denkmalwissenschaften und Denkmaltechnologien 2016 - 2018, KDWT (Hrsg.): Berichte des KDWT Band 1, 2019, S. 90-91, Doi: http://dx.doi.org/10.20378/irbo-54686.

\section{Rahrig 2019b:}

Rahrig, M.: „Praxistaugliche Digitalisierung barocker Prunkräume - hochauflösende 3DDokumentation des Kaisersaals der Neuen Residenz in Bamberg." In: Hoppe, S. / Burioni, M. (Hrsg.): Publikation zum 3D-Workshop: Digitale Raumdarstellungen. Barocke Kunst im Kontext aktueller Zugriffe der "spatial humanities", am 3.-4. April 2017 in Marburg, im Druck 2019, erscheint bei arthistoricum open-access.

\section{Rahrig/Street 2019:}

Rahrig, M. / Street, R.: „Rethinking Uniformity: Analysis of Rosso's Serial Casts of the Bambino ebreo through Digital Surface Comparison." In: Hecker, S. (Hrsg.): Finding Lost Wax: the Disappearance and Recovery of an Ancient Casting Technique and the Experiments of Medardo Rosso, erscheint im Brill Verlag, in der Reihe Studies in Art and Materiality, erscheint voraussichtlich Ende 2019.

\section{Rahrig/Torge 2019:}

Rahrig, M. / Torge, M.: „3D Inspection of the restoration and conservation of Stained Glass Windows using high resolution Structured Light Scanning." In: Int. Arch. Photogramm. Remote Sens. Spatial Inf. Sci., XLII-2/W15, 2019, S. 965-972, Doi: https://doi.org/10.5194/isprs-archives-XLII-2-W15-965-2019.

\section{Rantson et al. 2010:}

Rantoson, R. / Stolz, C. / Fofi, D. / Mériaudeau, F.: „Non Contact 3D Measurement Scheme for Transparent Objects Using UV Structured light." In: 20th International Conference on Pattern Recognition (CVPR), Istanbul, IEEE, 2010, S. 1646-1649, Doi: https://doi.org/10.1109/ICPR.2010.407.

\section{Remondino 2011:}

Remondino, F.: „Heritage Recording and 3D Modeling with Photogrammetry and 3D Scanning." In: Remote Sensing, 2011 (3), S. 1104-1138, Doi: https://doi.org/10.3390/rs3061104. 


\section{Remondino/Rizzi 2010:}

Remondino, F. / Rizzi, A.: „Reality-based 3D documentation of natural and cultural heritage sites techniques, problems, and examples." In: Appl Geomat, 2010 (2), S. 85-100, Doi: https://doi.org/10.1007/s12518-010-0025-x.

\section{Remondino 2013:}

Remondino, F.: „Worth a thousand words - Photogrammetry for archaeological 3D surveying." In: Opitz, R. S. / Cowley, D. C.: Interpreting Archaeological Topography - 3D Data, Visualisation and Observation, Occasional Publication of the Aerial Archaeological Research Group No. 5, 2013, S. 115122.

\section{Riedel et al. 2011:}

Riedel, A. / Henze, F. / Marbs, A.: „Paradigmenwechsel in der historischen Bauforschung? Ansätze für eine effektive Nutzung von 3D-Informationen." In: Heine, K. / Rheidt, K. / Henze, F. / Riedel, A. (Hrsg.): Von Handaufmass bis High Tech III. 3D in der historischen Bauforschung, Darmstadt/Mainz, 2011.

\section{Riegl 2019:}

Riegl Laser Measurement Systems GmbH: Riegl VZ-400i Datasheet, 2019, <http://www.riegl.com/uploads/tx pxpriegldownloads/RIEGL VZ-400i Datasheet 2019-05-28.pdf> letzter Zugriff 02.08.2019.

\section{Rieke-Zapp et al. 2017:}

Rieke-Zapp, D. H. / Trinkl, E.: „Face to face - close range inspection of head vases.” In: Int. Arch. Photogramm. Remote Sens. Spatial Inf. Sci., XLII-2/W5, ISPRS, 2017, S. 601-604, Doi: https://doi.org/10.5194/isprs-archives-XLII-2-W5-601-2017.

\section{Salemi et al. 2008:}

Salemi, G. / Achilli, V. / Boatto. G.: „3D Virtual Modelling of a Gothic Stained-Glass Panel.” In: Int. Arch. Photogramm. Remote Sens. Spatial Inf. Sci., Vol. XXXVII, Part B5, 2008, S. 297-302, $<$ https://www.isprs.org/proceedings/XXXVII/congress/5 pdf/52.pdf> letzter Zugriff 23.08.2019.

\section{Santana Quintero et al. 2019:}

Santana Quintero, M. / Fai, S. / Smith, L. / Duer, A. / Barazzetti, L.: „Ethical Framework for Heritage Recording Specialists Applying Digital Workflows for Conservation.” In: Int. Arch. Photogramm. Remote Sens. Spatial Inf. Sci., XLII-2/W15, 2019, S. 1063-1070, Doi: https://doi.org/10.5194/isprsarchives-XLII-2-W15-1063-2019.

\section{Schädler-Saub 2006:}

Schädler-Saub, U.: "Cesare Brandis Theorie der Restaurierung, ihre historische Bedeutung und ihre Aktualität.“ In: Schädler-Saub, U. / Jakobs, D. (Hrsg.): Cesare Brandi, Theorie der Restaurierung, ICOMOS (Hrsg), Hefte des Deutschen Nationalkomitees XLI, München, 2006, S. 21-39.

\section{Schmick et al. 2018:}

Schmik, J. / Colson, A. / Hastedt, H. / Luhmann, T.: „Photogrammetrische Monitoring und Deformationsanalyse der Bremer Hanse-Kogge" In: Luhmann, T. (Hrsg.): Beiträge Der Oldenburger 3DTage 2018, Vol. 17, Wichmann, Berlin, 2018, S. 42-54. 


\section{Scholz 2015:}

Scholz, H.: „Europeana - Digitale Dienstleistungs-Infrastruktur für Europas Kulturerbe.“ In: Euler, E. / Hagedorn-Saupe, M. / Maier, G. / Schweibenz, W. / Sieglerschmidt, J. (Hrsg.): Handbuch Kulturportale, Berlin / Boston 2015, S. $125-132$.

\section{Scott 2015:}

Scott, D. A.: "Conservation and authenticity: Interactions and enquiries." In: Studies in Conservation, Vol. 60: sup. 5, S. 291-305, Doi: https://doi.org/10.1179/2047058414Y.0000000159.

\section{Seneviratna 1987:}

Seneviratna, A.: The Temple of the Sacred Tooth Relic - An Architectural History of the Dalada Maligawa - The Symbol of the Buddhist Faith and Sovereignty in Sri Lanka, Colombo, 1987.

\section{Seville Charter 2011:}

International Forum of Virtual Archaeology (Hrsg.): Principles of Seville - International Principles of Virtual Archaeology, Final Draft, 2011, <http://smartheritage.com/wpcontent/uploads/2015/03/FINAL-DRAFT.pdf> letzter Zugriff 22.08.2019.

\section{Sommermeyer 2014:}

Sommermeyer, C.: „Innovative Langzeitarchivierung mit der Glassmasterdisc.“ In: Bienert, A. / Hemsley, J. / Santos, P: (Hrsg.): EVA Berlin 2014, Elektronische Medien \& Kunst, Kultur und Historie, Darmstadt/Berlin, 2014, S. 209-210.

\section{Spicale 2016:}

Spicale, V.: Topographische Aufnahmeanalyse barocker Decken - Methodenvergleich am Beispiel von Prunkräumen der Neuen Residenz Bamberg. Unveröffentlichte Abschlussarbeit im Masterstudiengang Denkmalpflege/Heritage Conservation, Universität Bamberg, 2016.

\section{Strlič 2015:}

Strlič, M.: A Brief Theory of Heritage Science. In: National Heritage Science Forum, 2015 $<$ https://nationalheritagescienceforum.wordpress.com/2015/04/16/a-brief-theory-of-heritagescience-by-professor-matija-strlic-ucl-institute-for-sustainable-heritage/> letzter Zugriff 10.07.2019.

\section{Strlič 2018:}

Strlič M.: „HeritageScience“:fachübergreifend und zukunftsorientiert. In: Angew. Chem., 2018, 130, 7380-7381. Doi: https://doi.org/10.1002/ange.201804246.

\section{Stylianidis/Georgopoulos 2016:}

Stylianidis, E. / Georgopoulos, A. / Remondino, F.: „Basics of Image-Based Modelling Techniques in Cultural Heritage 3D Recording." In: Stylianidis, E. / Remondino, F. (Hrsg.): 3D Recording, Documentation and Management of Cultural Heritage, Whittles Publishing, Dunbeath, 2016, S. 253304.

\section{Stylianidis/Remondino 2016:}

Stylianidis, E. / Remondino, F. (Hrsg.): 3D Recording, Documentation and Management of Cultural Heritage, Whittles Publishing, Dunbeath, 2016. 


\section{Tenschert 2019a:}

Tenschert, R.: „Varianten der Restaurierung - Beobachtungen zu Restaurierungsmaßnahmen an mittelalterlichen Portalen am Beispiel der Gnadenpforte des Bamberger Doms." In: Albrecht, S. / Breitling, S. / Drewello, R. (Hrsg.): Das Kirchenportal im Mittelalter, Petersberg, 2019, S. 250-261.

\section{Tenschert 2019b:}

Tenschert, R.: "Cathedral Norte Dame in Paris - The inscription of the south Transepts Façade: Medieval Relict or 19th Century Recreation?." In: Int. Arch. Photogramm. Remote Sens. Spatial Inf. Sci., XLII-2/W15, 2019, S. 1141-1147, Doi: https://doi.org/10.5194/isprs-archives-XLII-2-W15-1141$\underline{2019}$.

\section{Tenschert/Rahrig et al. 2019:}

Tenschert R. / Rahrig, M. / Drewello, R. /Kempgen, S.: „Scratches? Scribbles? Scripture! Revealing the unseen - 3D scanning of Glagolitic graffiti of the 10th century at Saint Naum." In: Proceedings of the 23th CHNT Vienna 2018, im Druck, 2019.

\section{Trautwein 2016:}

Trautwein, J.: Archivfähige 3D-Modellierung komplexer Oberflächen am Beispiel des Kaisergrabs im Bamberger Dom, unpublizierte Abschlussarbeit im Masterstudiengang Denkmalpflege an der Universität Bamberg, 2016.

\section{UNESCO 2003:}

UNESCO: Charta zur Bewahrung des digitalen Kulturerbes, Inoffizielle deutsche Arbeitsübersetzung der UNESCO-Kommissionen Deutschlands, Luxemburgs, Österreichs und der Schweiz, 2003, <http://www.unesco.de/infothek/dokumente/unesco-erklaerungen/charta-zur-bewahrung-desdigitalen-kulturerbes.html> (19.03.2017).

\section{Vantaa Document 2001:}

„The Vantaa Document - Towards a European Preventive Conservation Strategy." In: Putt, N. / Häyhä, H. (Hrsg.): European Preventive Conservation Strategy Project, 2001, S. 9-14, $<$ http://www.doernerinstitut.de/downloads/Vantaa Document 2000.pdf> letzter Zugriff 22.07.2019.

\section{VDL 2016:}

Verband der Landesdenkmalpfleger (VDL) (Hrsg.): Vorsorge, Pflege, Wartung - Empfehlungen zur Instandsetzung von Baudenkmalen und ihrer Ausstattung, Berichte zur Forschung und Praxis der Denkmalpflege in Deutschland Bd. 10, 2016, <https://www.vdldenkmalpflege.de/fileadmin/dateien/Berichte/Arbeitsheft 10 Vorsorge Pflege Wartung WEB.pdf> letzter Zugriff 22.07.2019

\section{Verhoeven 2012:}

Verhoeven, G.J.: „Methodes of Visualisation.” In: Edwards, H.G.M. / Vandenabeele, P. (Hrsg.): Analytical Archeometry, selected Topics, 2012, S. 3-48, Doi: http://dx.doi.org/10.1039/9781849732741.

\section{Verhoeven 2016:}

Verhoeven, G.: „Basics of Photography for Cultural Heritage Imaging.” In: Stylianidis, E. / Remondino, F. (Hrsg.): 3D Recording, Documentation and Management of Cultural Heritage, Whittles Publishing, Dunbeath, 2016, S. 127-251. 


\section{Verhoeven/Missinne 2017:}

Verhoeven, G.J. / Missinne, S. J.: „Unfolding Leonardo da Vinci's Globe (AD 1504) to reveal its historical World Map." In: ISPRS Ann. Photogramm. Remote Sens. Spatial Inf. Sci., IV-2/W2, 2017, S. 303-310, Doi: https://doi.org/10.5194/isprs-annals-IV-2-W2-303-2017.

\section{Vinken 2017:}

Vinken, G.: „Das Digitale und die Denkmalpflege. Einführung in eine komplexe Beziehung." In: Franz, B. / Vinken, G. (Hrsg.): Das Digitale und die Denkmalpflege: Bestandserfassung - Denkmalvermittlung - Datenarchivierung - Rekonstruktion verlorener Objekte, Veröffentlichungen des Arbeitskreises Theorie und Lehre der Denkmalpflege e.V., Band 26, Heidelberg, 2017, S. 12-19, Doi: http://dx.doi.org/10.11588/arthistoricum.263.348.

\section{Warda 2011:}

Warda, J.: The AIC Guido to Digital Photography and Conservation Documentation, second edition, American Institute for Conservation, Washington, 2011.

Webb et al. 2018:

Webb, E. K. / Robson, S. / Mac Donald, L. / Gardise, D. / Evans, R.: „Spectral and 3D Cultural Heritage Documentation using a Modified Camera." In: Int. Arch. Photogramm. Remote Sens. Spatial Inf. Sci., XLII-2, 2018, S.1183-1190, Doi: https://doi.org/10.5194/isprs-archives-XLII-2-1183-2018.

\section{Wedepohl 2003:}

Wedepohl, K. H.: Glas in Antike und Mittelalter. Geschichte eines Werkstoffs, E. Schweizerbart'sche Verlagsbuchhandlung, Stuttgart, 2003.

\section{Wiedemann 2004:}

Wiedemann, A.: Handbuch Bauwerksvermessung. Geodäsie - Photogrammetrie - Laserscanning, Basel, 2004.

\section{Woldering 2008:}

Woldering, B.: „Europeana: Die Europäische Digitale Bibliothek - Entwicklungen und Perspektiven. “ In: Zeitschrift für Bibliothekswesen und Bibliographie (ZfBB), Bd. 55, 2008, S. 33.

\section{Wulf-Rheidt 2017:}

Wulf-Rheidt, U.: „Copy and paste - Erinnerungskultur aus dem 3D-Drucker?“ In: Franz, B. / Vinken, G. (Hrsg.): Das Digitale und die Denkmalpflege: Bestandserfassung - Denkmalvermittlung Datenarchivierung - Rekonstruktion verlorener Objekte, Veröffentlichungen des Arbeitskreises Theorie und Lehre der Denkmalpflege e.V., Band 26, Heidelberg, 2017, S. 32-37, Doi: http://dx.doi.org/10.11588/arthistoricum.263.348.

\section{Yadong/Peihua 2006:}

Yadong, L. / Peihua, G.: „Automatic Localization and Comparison for Free-Form Surface Inspection.” In: Journal of Manufacturing Systems, Vol. 25, no. 4, Elsevir, 2006, S. 251-268, Doi: https://doi.org/10.1016/S0278-6125(08)00007-1. 


\section{Yeung et al. 2011:}

Yeung, S.K. / Wu, T.P. / Tang, CH. K. / Chan, T. F. / Osher, S.: „Adequate reconstruction of transparent objects on a shoestring budget." In: Proceedings of IEEE Computer Society Conference on Computer Vision and Pattern Recognition (CVPR), Colorado Springs, CO, USA, IEEE, 2011, S. 2513-2520, Doi: https://doi.org/10.1109/CVPR.2011.5995472.

\section{Zalma et al. 2011:}

Zalama, E. / Gómez, J. / Llamas, J. / Melero, A.: „An effective texture mapping approach for 3D models obtained from laser scanner data to building documentation." In: Computer Aided Civil and Infrastructure Engineering, Vol. 26, 2011, S. 381-392, Doi: https://doi.org/10.1111/j.14678667.2010.00699.x.

\section{Zeiss Optotechnik 2019:}

Carl Zeiss Optotechnik GmbH: Comet 6, Technische Daten, 2019, <https://optotechnik.zeiss.com/produkte/3d-digitalisierung/comet-6/technische-daten> letzter Zugriff 02.08.2019. 